$$
\text { UNIVERSIDADE DE SÃO PAULO }
$$

FACULDADE DE FILOSOFIA, LETRAS E CIÊNCIAS HUMANAS

DEPARTAMENTO DE LETRAS MODERNAS

PROGRAMA DE PÓS-GRADUAÇÃO EM LÍNGUA E LITERATURA ALEMÃ

RAPHAEL DA SILVEIRA

\title{
O LIVRO DIDÁTICO NOS PROCESSOS DE ENSINO-APRENDIZAGEM DE ALEMÃO NO CEL: UMA ANÁLISE DE NECESSIDADES
}

\author{
Versão Corrigida
}

São Paulo

2018 


\begin{abstract}
Dissertação de mestrado apresentada ao Programa de Pós-Graduação em Língua e Literatura Alemã da Faculdade de Filosofia, Letras e Ciências Humanas, da Universidade de São Paulo, como parte dos requisitos para a obtenção do título de mestre em Letras.
\end{abstract}

Orientadora: Profa. Dra. Dörthe Uphoff

São Paulo 
Autorizo a reprodução e divulgação total ou parcial deste trabalho, por qualquer meio convencional ou eletrônico, para fins de estudo e pesquisa, desde que citada a fonte.

Catalogação na Publicação

Serviço de Biblioteca e Documentação

Faculdade de Filosofia, Letras e Ciências Humanas da Universidade de São Paulo

ENSINO-APRENDIZAGEM DE ALEMÃO NO CEL: UMA ANÁLISE DE

NECESSIDADES / Raphael Silveira ; orientadora

Dörthe Uphoff. - São Paulo, 2018.

$205 \mathrm{f}$.

Dissertação (Mestrado) - Faculdade de Filosofia, Letras e Ciências Humanas da Universidade de são Paulo. Departamento de Letras Modernas. Área de concentração: Língua e Literatura Alemã.

1. Ensino e aprendizagem . 2. Livro Didático. 3. Língua estrangeira. I. Uphoff, Dörthe, orient. II. Título. 
SILVEIRA, R. O livro didático nos processos de ensino-aprendizagem de alemão no CEL: uma análise de necessidades. Dissertação apresentada à Faculdade de Filosofia, Letras e Ciências Humanas da Universidade de São Paulo para obtenção do título de mestre em Língua e Literatura Alemã.

Aprovado em:

Banca examinadora

Prof. Dr. Instituição:

Julgamento: Assinatura:

Prof. Dr. Instituição:

Julgamento: Assinatura:

Prof. Dr. Instituição:

Julgamento: Assinatura: 
Dedico este trabalho à minha família, que me apoiou incondicionalmente em todas as etapas da pesquisa e que me indicou um caminho seguro nos momentos de maior dificuldade. 


\section{Agradecimentos}

À minha orientadora, Profa. Dra. Dörthe Uphoff, por sua paciência, dedicação e determinação sem os quais esse trabalho não seria uma realidade.

À equipe gestora da E.E. Walther Weiszflog, que permitiu que a pesquisa fosse feita nas dependências da escola.

Aos meus alunos, que muito gentilmente concordaram em participar desta pesquisa fornecendo as suas valiosas opiniões.

Aos professores de alemão das diversas unidades do CEL do Estado de São Paulo que preencheram o questionário enviado a eles antes da primeira qualificação.

Aos Professores Drs. José da Silva Simões e Renato Ferreira da Silva por suas valiosas contribuições nos exames de qualificação e pela ajuda na mudança de foco da pesquisa.

À Beatriz, aluna da graduação em alemão, por disponibilizar seu texto para servir de base para o desenvolvimento de uma atividade da coleta de dados e por aceitar gravar um depoimento que foi mostrado aos alunos participantes da pesquisa.

Aos professores que participaram da banca examinadora de defesa.

Aos meus pais, Neiva e Carlos, que me apoiaram de todas as formas possíveis para a realização deste trabalho.

Aos amigos, que cederam seu tempo para discutir temas relacionados à pesquisa.

A todos que participaram direta ou indiretamente para que essa pesquisa fosse concluída. 


\section{RESUMO}

SILVEIRA, R. O livro didático nos processos de ensino-aprendizagem de alemão no CEL: uma análise de necessidades. Dissertação (mestrado), Faculdade de Filosofia, Letras e Ciências Humanas, Universidade de São Paulo, 2018.

Os Centros de Estudos de Línguas - CEL - do Estado de São Paulo oferecem aos alunos da rede pública estadual a oportunidade de cursar, em caráter eletivo, um outro idioma. Em geral, até mesmo por questões que envolvem os objetivos de criação dessa iniciativa, os idiomas mais procurados são o espanhol e o inglês. Contudo, em algumas unidades do CEL, de acordo com a demanda local, há a possibilidade de abrir turmas de idiomas como o alemão. Nesses casos, porém, há uma particularidade no que concerne ao uso do LD, já que os alunos de alemão não ganham esse material da escola, uma vez que o idioma não faz parte do Programa Nacional do Livro Didático - PNLD - como o inglês e o espanhol. O LD, por sua vez, está disponível na escola através de doação feita pelo Instituto Goethe, mas não pode ser entregue para que os alunos levem um exemplar para casa. Nesse sentido, esse trabalho busca analisar quais as expectativas dos alunos em relação ao LD utilizado por eles durante as aulas e os efeitos que a presença ou a ausência desse dispositivo gera no processo de ensino-aprendizagem de alemão nesse contexto. Para tal, foi realizada uma análise de necessidades subjetivas e processuais (cf. WEISSENBERG, 2012) com foco, respectivamente, na visão dos alunos e do professor de uma turma específica de uma unidade do CEL, situado em um município da Grande São Paulo. Essa análise foi realizada através dos dados obtidos com o desenvolvimento e aplicação de atividades didáticas oferecidas aos alunos em forma de estações e também de um questionário. A coleta dos dados ocorreu em três etapas nos meses de março, maio e junho de 2017. A análise dos dados aponta para o fato que os alunos, apesar de já terem tido contato com outras línguas estrangeiras, não desenvolveram as estratégias necessárias para estudar uma língua estrangeira. Além disso, as suas opiniões acerca do LD fornecidas nos questionários corroboram com o fato que eles não se apropriam desse dispositivo no momento de estudar, apesar de declararem tal ferramenta como sendo de muita importância para o seu processo de aprendizagem de alemão.

Palavras-chave: Livro didático, CEL, Língua estrangeira, Alemão, Análise de necessidades 
SILVEIRA, R. The textbook in the German teaching-learning processes in the CEL: a needs analysis. Dissertação (mestrado), Faculdade de Filosofia, Letras e Ciências Humanas, Universidade de São Paulo, 2018.

The Centers of Language Studies (Centros de Estudos de Línguas - CEL) of the State of São Paulo offer public school students the opportunity to study, in an elective way, another language. In general, even for issues involving the objectives of this initiative, the most sought languages are Spanish and English. However there is the possibility of having groups for languages like German, according to the local demand. In these Centers, there is a particularity regarding the use of the textbook, because the German studies do not receive the textbook from the school, since the German language is not part of the National Textbook Program (Programa Nacional do Livro didático - PNLD) as are English and Spanish. The textbook is available at school through a donation made by the Goethe Institut, but the students can't take it home with them. Therefore, this research seeks to analyze the students' expectations regarding the textbook that is used during the German classes and the effect that the presence or the absence of this device generates in the German teaching-learning process in this specific context. For this purpose, a subjective and a procedural analysis focused on the students' and the teacher's needs of a specific group of a CEL was carried out (see WEISSENBERG, 2012). This analysis was performed through the data obtained with the development and application of didactic activities offered to students in the form of stations and also a questionnaire. Data collection took place in three stages in the months of March, May and June 2017. Data analysis points to the fact that the students, despite having already had contact with other foreign languages, did not develop the necessary strategies to study a foreign language. In addition, their opinion about the textbook provided in the questionnaires corroborate that they do not appropriate the device during their studies, although they declare that the textbook is of great importance to their German learning process.

Keywords: Textbook, CEL, Foreign Language, German, Needs analysis 


\section{ZUSAMMENFASSUNG}

\section{SILVEIRA, R. Das Lehrwek in Lehr- und Lernprozesse des Deutschen als}

Fremdsprache am CEL: eine Bedarfsanalyse. Dissertação (mestrado), Faculdade de Filosofia, Letras e Ciências Humanas, Universidade de São Paulo, 2018.

Die Sprachenzentren (Centros de Estudos de Línguas - CEL) - des Bundesstaates São Paulo bieten den Schülern der staatlichen öffentlichen Schulen von São Paulo die Gelegenheit, als Wahlfach eine weitere Sprache zu lernen. Aufgrund der historischen Hintergründe dieser Einrichtung sind die am meisten nachgefragten Sprachen normalerweiser Spanisch und Englisch. In einigen Schulen, in denen ein CEL funktioniert, gibt es je nach lokalen Anforderungen außerdem die Möglichkeit, andere Sprachkurse wie Deutsch anzubieten. Eine Besonderheit bezüglich der Verwendung des Lehrwerks ist hier jedoch, dass die Schüler dieses Material nicht von der Schule erhalten, da die deutsche Sprache nicht Teil des Brasilianischen Bundesprogramms für Lehrwerke (Programa Nacional do Livro Didático - PNLD) ist. Englisch und Spanisch nehmen an diesem Programm teil. Das Lehrwerk steht in der Schule wegen einer Spende des Goethe Instituts zur Verfügung, aber es kann von den Schülern nicht mit nach Hause genommen werden. In diesem Sinne wird in dieser Arbeit analysiert, welche Erwartungen Schülerinnen und Schüler in Bezug auf das von innen im Unterricht verwendete Lehrwerk haben und welche Auswirkungen die nur teilweise garantierte Präsenz des Lehrwerk für die Lehr- und Lernprozesse in diesem Zusammenhang möglicherweise haben. Dazu wird eine Analyse subjektiver und prozessorientierter Bedarfe durgeführt (vgl. WEISSENBERG, 2012). Die Analyse konzentriert sich auf die Lerner- und Lehrerperspektive von einer bestimmten Gruppe eines ausgewählten Sprachenzentrums (CEL). Die analysierten Daten wurden mittels der Entwicklung und Anwendung von Fragebögen und Stationenlernen erhalten. Die Datenanalyse weist darauf hin, dass die Schüler, obwohl sie schon vorher Kontakt mit anderen Sprachen hatten, keine effektiven Lernstrategien für Fremdsprachen entwickelt hatten. Darüber hinaus bestätigen ihre Meinungen über das Lehrwerk in den Fragebögen die Tatsache, dass sie sich das Lehrwerk in nur ungenügenden Maßen für ihren Lernprozess aneignen, obwohl sie äußern, dass das Lehrwerk von großer Bedeutung für sie ist.

Schlüsselwörter: Lehrwerk, CEL, Fremdsprache, Deutsch, Bedarfsanalyse. 


\section{Lista de llustrações}

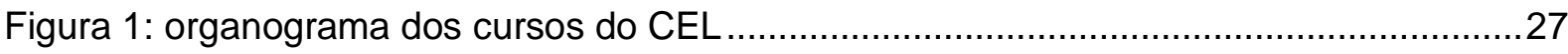

Figura 2: Einstiegsseite produzida pelos respondentes A5, A6 e A12 ...............................121

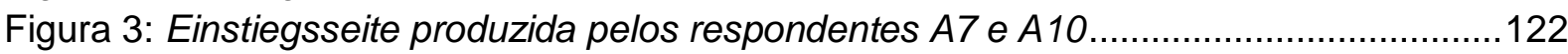

\section{Lista de quadros}

Quadro 1: Perguntas aplicadas como pilotagem de um questionário.....................................55

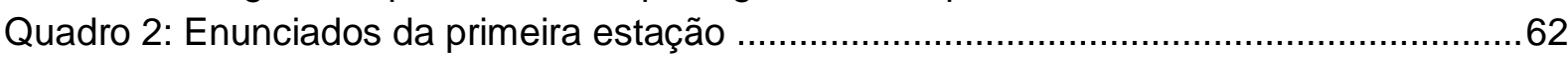

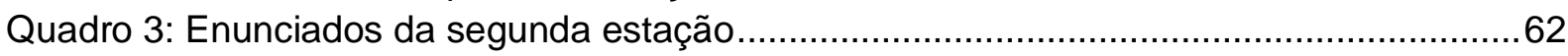

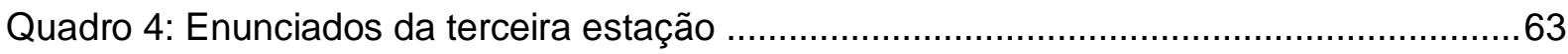

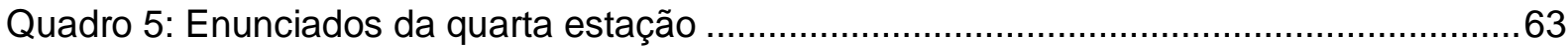

Quadro 6: Perguntas da atividade "Para Refletir" ...............................................................64

Quadro 7: Enunciados da primeira estação - segunda coleta............................................65

Quadro 8: Enunciados da segunda estação - segunda coleta.............................................66

Quadro 9: Enunciados da terceira estação - segunda coleta...............................................66

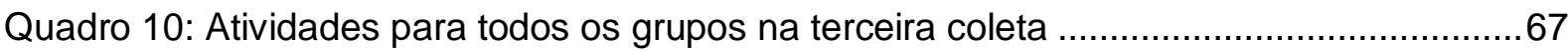

Quadro 11: Atividades do primeiro grupo - terceira coleta ................................................68

Quadro 12: Atividades do segundo grupo - terceira coleta .................................................69

Quadro 13: Atividades do terceiro grupo - terceira coleta .................................................69

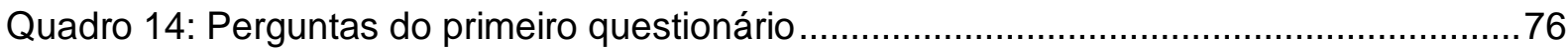

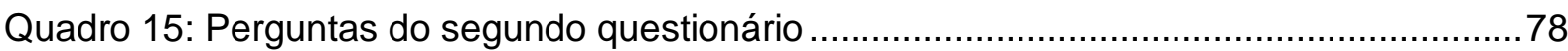

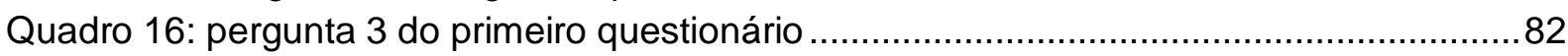

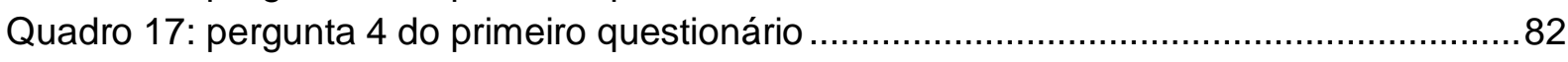

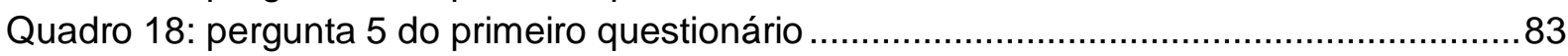

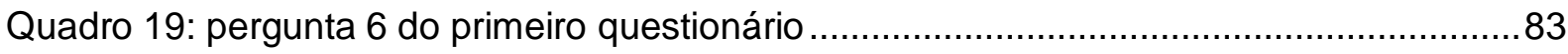

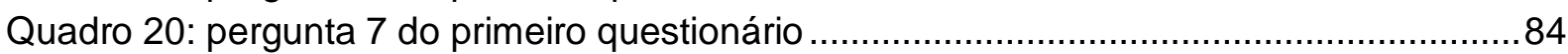

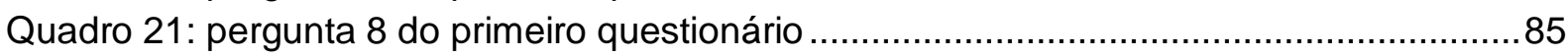

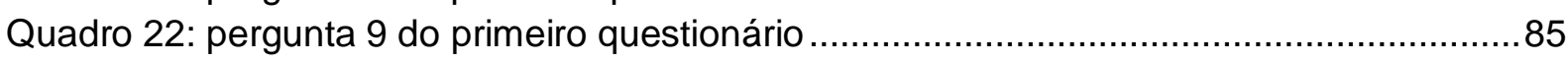

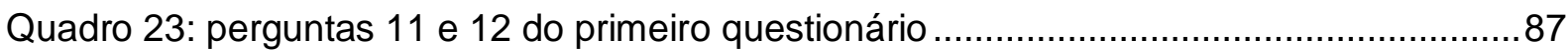

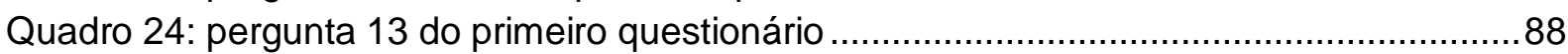

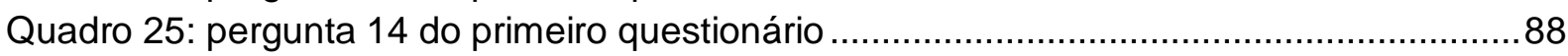

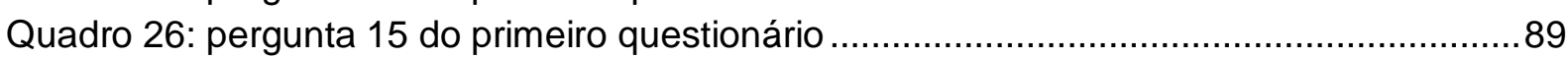

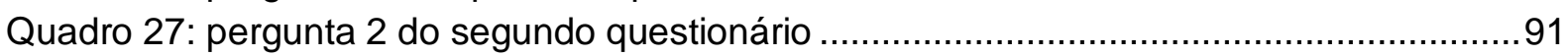

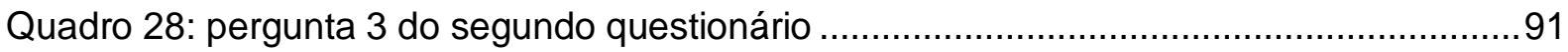

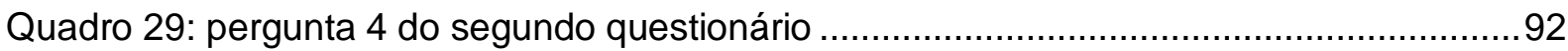

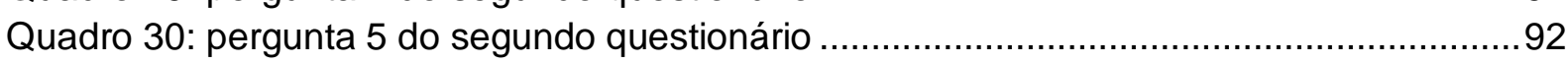

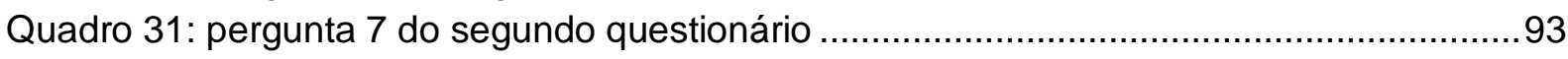

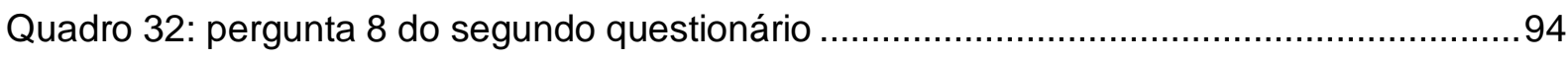

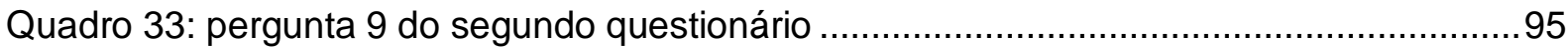

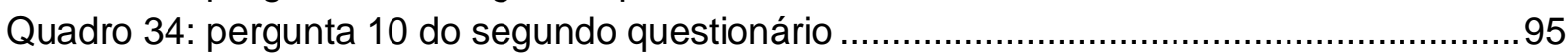

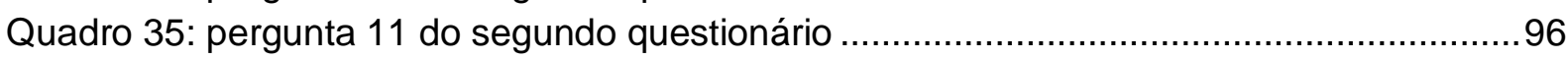

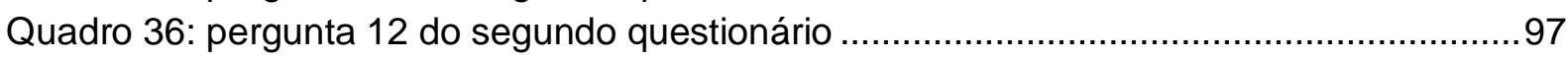

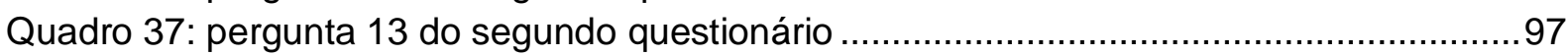

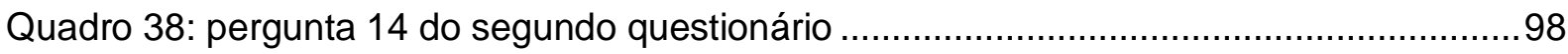

Quadro 39: pergunta 15 do segundo questionário .............................................................99 


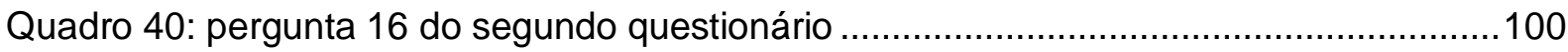

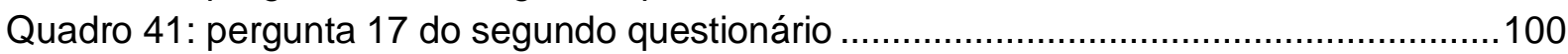

Quadro 42: pergunta 18 do segundo questionário ............................................................101

Quadro 43: pergunta 1 da primeira estação do primeiro dia da coleta de dados .................111

Quadro 44: Pergunta 1 da primeira estação do segundo dia de coleta de dados................135

Quadro 45: pergunta 12 do segundo questionário .............................................................139

Quadro 46: pergunta 8 do segundo questionário ............................................................141

Quadro 47perguntas 12 e 15 do segundo questionário ...................................................141

\section{Lista de tabelas}

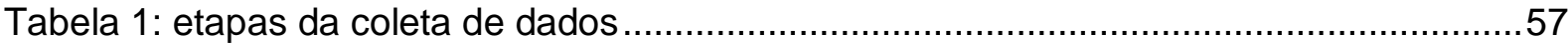

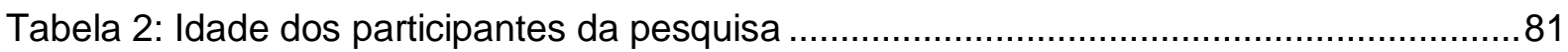

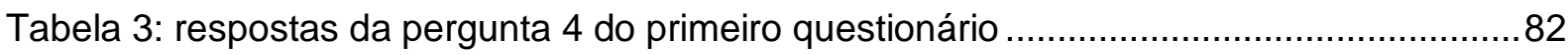

Tabela 4: respostas da pergunta 7 do primeiro questionário .................................................. 84

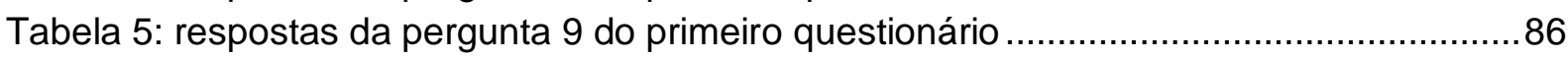

Tabela 6: respostas da pergunta 13 do primeiro questionário ..............................................88

Tabela 7: respostas da pergunta 3 do segundo questionário .............................................91

Tabela 8: respostas da pergunta 7 do segundo questionário ...............................................94

Tabela 9: respostas da pergunta 8 do segundo questionário ..............................................95

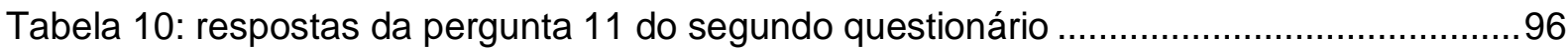

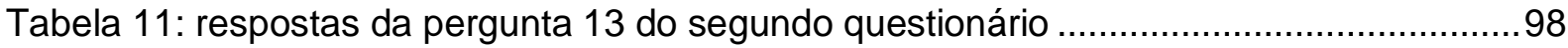

Tabela 12: respostas da pergunta 16 do segundo questionário ........................................100

Tabela 13: respostas obtidas nas perguntas 11 e 12 do segundo questionário ..................138

Tabela 14: dados das perguntas 7 e 8 do segundo questionário .......................................143

\section{Lista de abreviaturas e siglas}

CEL - Centro de Estudos de Línguas

LD - Livro didático

LE - Língua estrangeira

LDB - Lei de Diretrizes e Bases da Educação

OCEM - Orientações Curriculares para o Ensino Médio

PCNs - Parâmetros Curriculares Nacionais

QECR - Quadro Europeu Comum de Referência para as Línguas 


\section{Sumário}

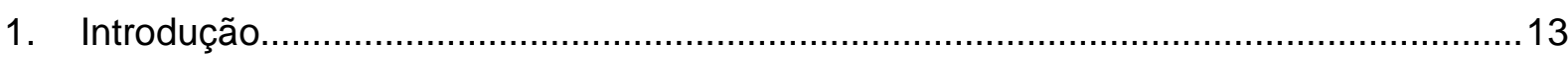

1.1. Delimitando o objeto de pesquisa .............................................................. 13

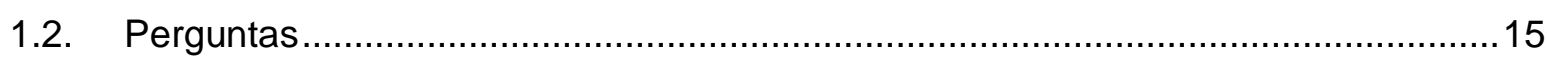

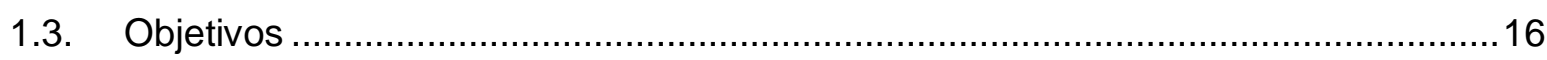

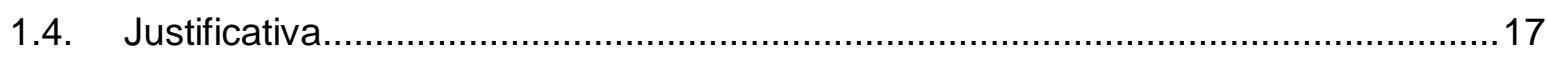

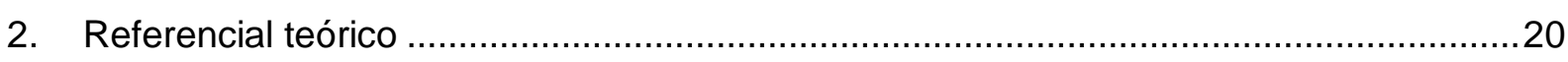

2.1. Aspectos políticos do ensino de línguas ...........................................................20

2.1.1. O ensino de LE no Brasil: documentos oficiais e contexto ................................20

2.1.2. Documentos oficiais que regem o funcionamento do CEL .............................23

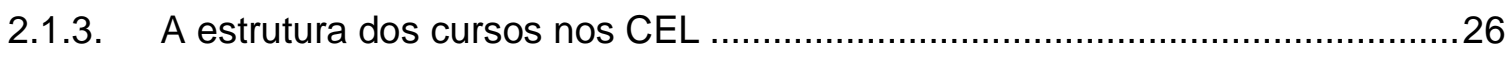

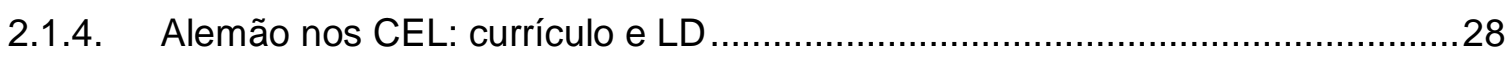

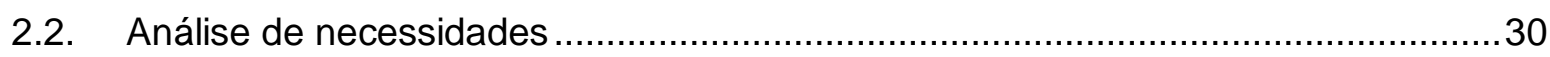

2.2.1. Definição e propósitos da análise de necessidades.........................................31

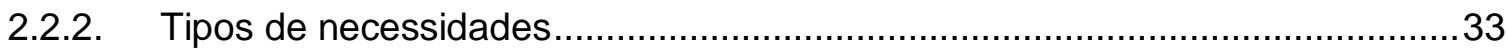

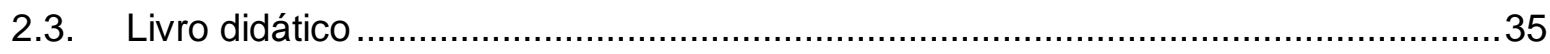

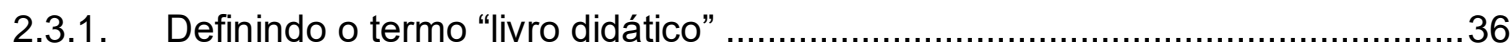

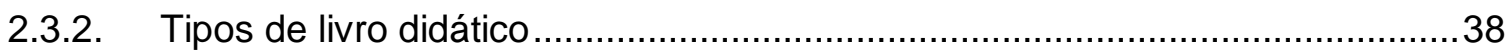

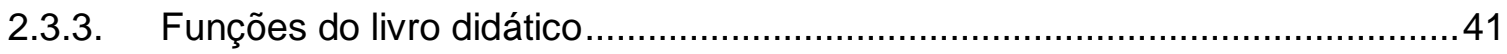

2.3.4. O livro didático e a análise de necessidades...................................................44

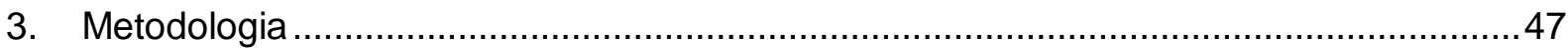

3.1. Da natureza do trabalho e o contexto da pesquisa: aspectos gerais ......................47

3.1.1. Definição do termo "estudo de caso" e o caráter da pesquisa ...........................48

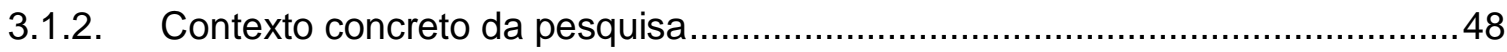

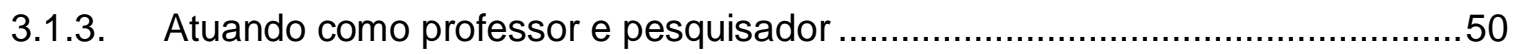

3.2. Análise de necessidades por meio da triangulação de dados ................................52

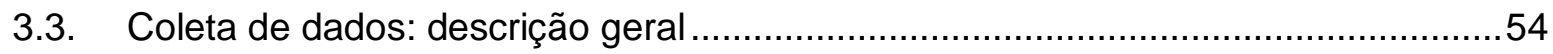

3.3.1. Desenvolvimento e aplicação da pilotagem .................................................54

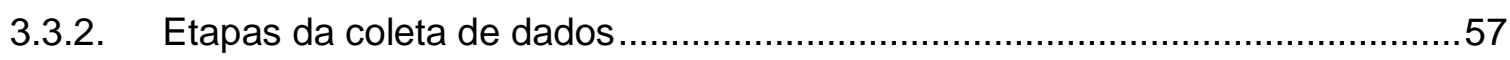

3.4. Atividades didáticas: desenvolvimento e aplicação .............................................58

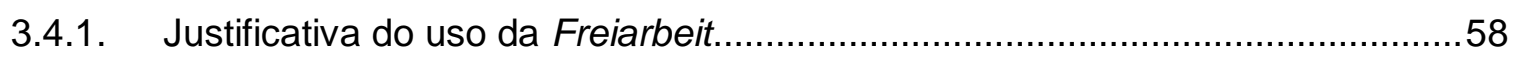

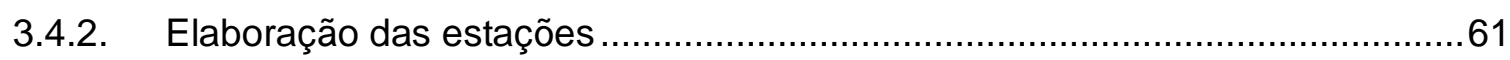

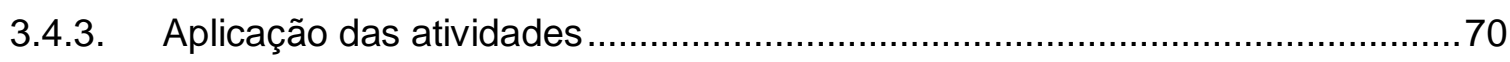

3.5. Questionário: desenvolvimento e aplicação................................................... 72 
3.5.1. Justificativa do uso de questionários ......................................................... 72

3.5.2. Elaboração do questionário...................................................................... 73

3.5.3. Aplicação do questionário ...................................................................... 79

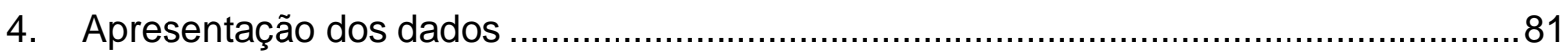

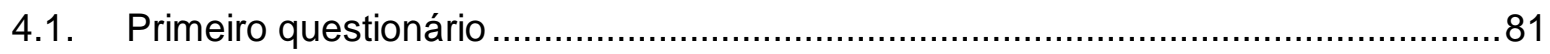

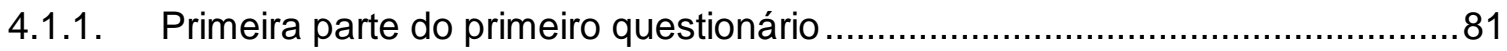

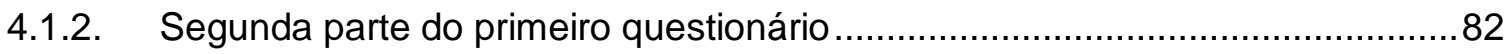

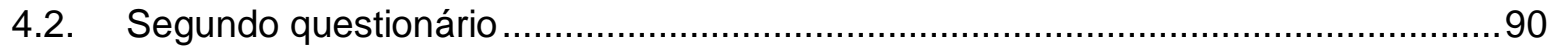

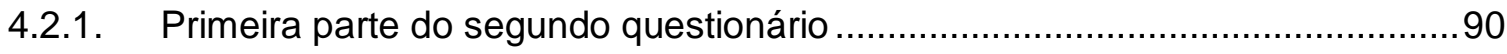

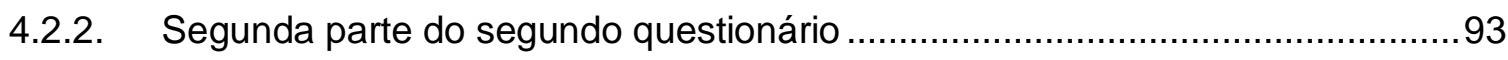

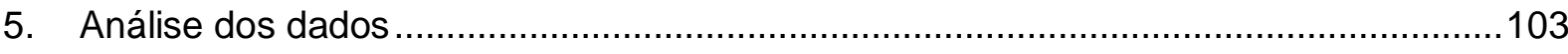

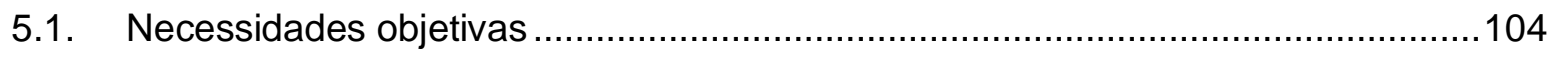

5.1.1. A organização do curso e o uso do LD ........................................................106

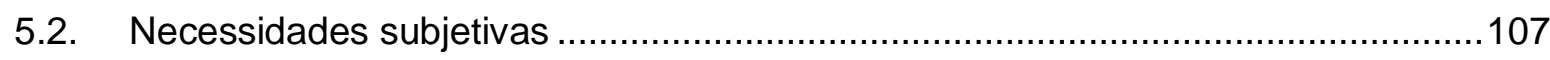

5.2.1. A presença do LD e a importância atribuída a ele ........................................108

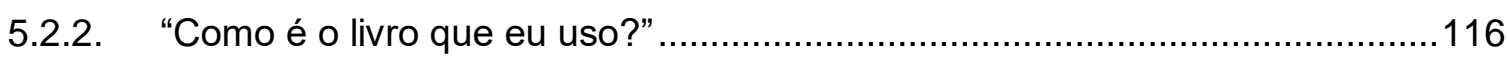

5.2.3. Representações e expectativas ............................................................. 120

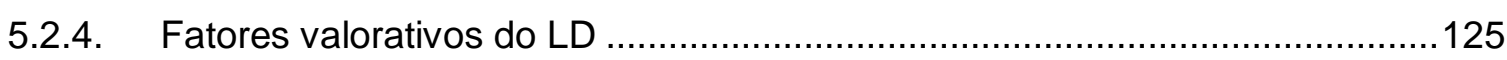

5.2.5. O LD e o estudo fora das aulas ......................................................... 130

5.3. Necessidades processuais ..................................................................... 134

5.3.1. Refletir sobre o LD na presença do professor/ pesquisador ..........................134

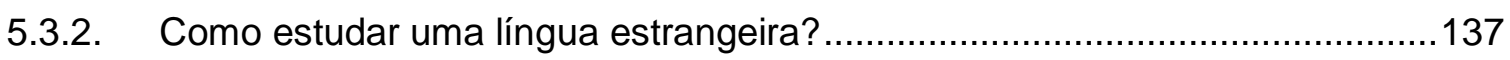

5.3.3. Incompatibilidade nos discursos: o que é dito e o que acontece ....................140

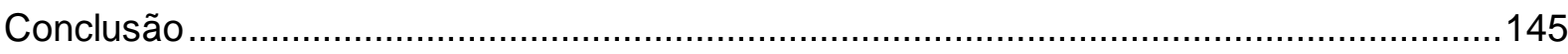

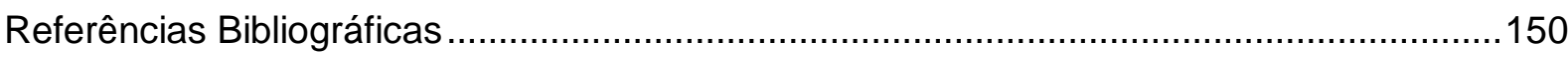

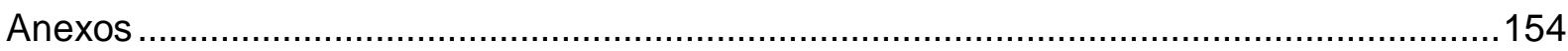

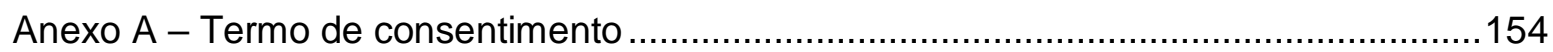

Anexo B - Estações e respostas da primeira etapa da coleta de dados ...........................155

Anexo C - Atividade "Para refletir" aplicada no final do primeiro dia de coleta ................174

Anexo D - Estações e respostas da segunda etapa da coleta de dados ..........................180

Estação 1: EINSTIEGSSEITEN und DAS KANN ICH SCHON .......................................180

Anexo E - Instruções, perguntas e textos da terceira etapa de coleta .............................190

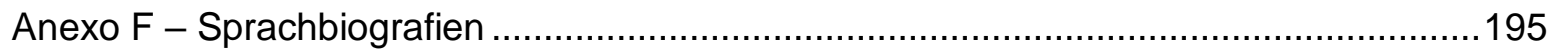

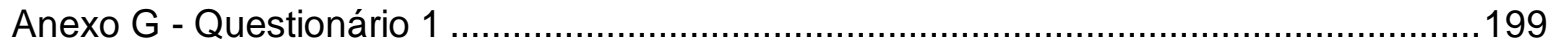

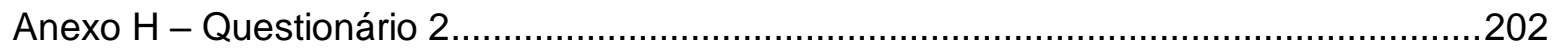




\section{Introdução}

\subsection{Delimitando o objeto de pesquisa}

Os CEL - Centros de Estudo de Línguas - existem no estado de São Paulo há mais de 30 anos desde que foram criados por um decreto de 1987. Desde então, tais Centros têm proporcionado aos alunos da rede pública nos níveis fundamental e médio do estado de São Paulo a oportunidade de estudar um outro idioma em caráter eletivo de acordo com demandas locais e com a disponibilidade de professores devidamente inscritos na rede pública estadual para lecionar esse idioma.

Apesar de já existirem há algum tempo, a iniciativa do CEL ainda se restringe aos locais em que há uma unidade disponível e, mesmo dentro da rede estadual de ensino, há aqueles que desconhecem a oferta de idiomas da maneira como ocorre. Inclusive entre professores que atuam na rede estadual há anos, a informação de que o curso de alemão ou mesmo que cursos de idiomas são oferecidos nesses moldes ainda causa estranheza.

No início de 2015 fui informado que uma unidade do CEL havia sido implantada em uma escola pública da minha cidade e que havia a possibilidade de oferecer aulas de alemão caso algum professor efetuasse a sua inscrição junto à Diretoria Regional de Ensino. Por isso, após passar por todos os trâmites legais, iniciei as atividades como docente no mesmo ano, ainda no primeiro semestre.

Apesar de já ter alguma experiência com o ensino de línguas estrangeiras (LE) obtida concomitantemente à realização da graduação em Letras finalizada em 2014, o primeiro contato com o CEL mostrou uma série de fatores intrigantes em relação à estrutura dos cursos e, sobretudo, à relação dos alunos com a aprendizagem de LE.

Mesmo estudando inglês no ensino regular e até mesmo tendo frequentado aulas de LE em escolas de idiomas, os alunos, na minha avaliação como professor, 
demonstravam despreparo para acompanhar as aulas de alemão. Entre os fatores observados, notou-se que, para eles, o registro no caderno parecia mais importante do que as atividades realizadas ao longo da aula, de modo que muitas atividades comunicativas aplicadas nas primeiras aulas se mostraram ineficazes no sentido de não atingirem seu objetivo, já que os alunos estavam preocupados em traduzir todas as palavras e anotar ou copiar palavras em seu caderno de maneira desordenada.

Outro fato relevante nesse contexto tem relação com a quantidade de livros didáticos (LD) disponíveis naquela unidade do CEL. Como as turmas eram novas e tinham aproximadamente 35 alunos cada, não havia quantidade suficiente de LD para os alunos utilizarem durante as aulas e os exemplares disponíveis não podiam ser emprestados para que os alunos os levassem para suas casas. Dessa forma, as atividades de ensino-aprendizagem eram diretamente afetadas por essa ausência parcial do LD que, por sua vez, precisava ser compensada tanto pelo professor, quanto pelos alunos.

Para isso, elaborei enquanto professor algumas estratégias a fim de que fosse possível utilizar o LD durante as aulas e também para o trabalho com lições de casa. Entre essas estratégias, estava o fornecimento de cópias de páginas do LD que seriam utilizadas durante as aulas, além da elaboração de exercícios alternativos e da adaptação de exercícios do LD que possibilitassem a sua não utilização momentânea. Vale ressaltar que, durante esse processo, os alunos eram incentivados a adquirir seus próprios exemplares do LD ou cópias. Contudo, partindo do pressuposto de que a escola não pode obrigar o aluno a adquirir tais materiais, as ações de incentivo se mostravam deficientes já que os alunos não demonstravam interesse em ter o seu próprio LD.

Neste ínterim, notei como professor que a ausência do livro afetava de forma negativa o andamento do curso já que os alunos não realizavam atividades de casa afirmando não ter o LD e também devido ao fato de que era sempre preciso retomar conteúdos, já que a progressão era prejudicada devido à falta de empenho dos alunos em estudar sem o auxílio do LD. Além disso, levando em conta a percepção de que muitos dos alunos não achavam importante ter o LD em casa para estudar, surgiu a ideia para a presente pesquisa de examinar o posicionamento dos alunos quanto à ausência parcial do LD durante o seu processo de aprendizagem da língua 
alemã em uma unidade do CEL e também sobre o papel atribuído ao LD por esses alunos durante o seu processo de aprendizagem da língua alemã.

Vale ressaltar que foram necessárias uma série de mudanças significativas em relação ao que se buscava pesquisar para que esta pesquisa atingisse os moldes atuais. Inicialmente, minha preocupação principal consistia na relação que se estabelecia entre o professor e o LD nesse contexto onde o dispositivo nem sempre está disponível para os alunos, apesar de nortear o curso em relação aos conteúdos apresentados e a sua organização nos semestres. Entretanto, a dificuldade em conseguir dados consistentes que demonstrassem os usos do LD nesse contexto a partir da visão do professor fez com que o foco passasse para os alunos.

Com essa mudança, inicialmente existia a hipótese de que a quantidade disponível de LD para a utilização durante as aulas era um fator decisivo para influenciar o processo de aprendizagem dos alunos. Contudo, era preciso verificar essa hipótese a partir do olhar dos próprios alunos participantes do curso de alemão, a fim de entender um pouco melhor como esses alunos interpretavam o papel do LD dentro do seu processo de aprendizagem de alemão. Dito de outra forma: era preciso deixar que os alunos refletissem acerca da importância do LD ao longo do seu processo de aprendizagem de alemão no CEL.

Nesse sentido, levando em consideração os alunos e o LD utilizado por eles durante o seu processo de aprendizagem de alemão, surgiram as seguintes perguntas que norteiam este trabalho.

\subsection{Perguntas}

A pesquisa se orientou através das seguintes perguntas norteadoras:

1. Quais são as expectativas dos alunos do CEL investigado com relação ao LD utilizado? 
2. Como a presença ou a ausência de LD afeta o processo de ensinoaprendizagem de acordo com a visão dos alunos? pesquisa.

A partir destas duas perguntas, foram elaborados os objetivos desta

\subsection{Objetivos}

As duas perguntas elencadas anteriormente apresentam a visão dos alunos, no caso da pergunta 1, e do próprio professor, na pergunta 2. Dessa forma, levando em conta que as perguntas apontam para aspectos observáveis a partir desses dois pontos de vista, chegou-se à conclusão de que elas poderiam ser respondidas a partir de uma análise de necessidades que levasse em consideração essas duas perspectivas. O conceito de análise de necessidades é discutido na seção 2.2. deste trabalho.

Nesse sentido, o objetivo principal da pesquisa é realizar uma análise de necessidades subjetivas e processuais dos alunos de uma unidade do CEL por meio de questionários e atividades didáticas no intuito de verificar as expectativas e as dificuldades dos alunos em relação ao LD durante o seu processo de aprendizagem de alemão nos estágios finais do segundo nível do curso de alemão, de acordo com a divisão dos cursos nos Centros.

As necessidades subjetivas, com foco nos alunos, foram analisadas a partir das opiniões que os alunos expressaram acerca do LD e da sua importância para o aprendizado de alemão no CEL. Por outro lado, as necessidades processuais, observadas pelo professor, foram analisadas a partir das dificuldades que surgiram com a aplicação das atividades e questionários de modo a verificar possíveis divergências entre a fala dos alunos e a sua prática. 


\subsection{Justificativa}

De acordo com as orientações pedagógicas recebidas no início das minhas atividades no CEL, o LD deve ser a base do planejamento das aulas de alemão. No total, o curso de alemão dos CEL dura seis semestres nos quais os volumes A1 e A2 do material Planet da editora Hueber eram adotados. Cada um dos livros deveria durar aproximadamente três semestres, que é o tempo que dura cada um dos níveis do curso. Assim, o contexto apresentado indica que esse dispositivo ocupa uma posição de destaque e cumpre inclusive o papel de organizar o curso quanto aos temas e quanto à progressão do curso em si.

Apesar da importância atribuída ao dispositivo, existe um fator que não pode ser desconsiderado quando se trata sobre esse contexto específico do CEL no que se refere à oferta das aulas de alemão. Como o idioma não faz parte da grade obrigatória de aulas oferecidas pelo Estado de São Paulo ou, ainda, pelo Brasil, não há a compra e a distribuição massiva de materiais didáticos de alemão como ocorre com outros idiomas, como o inglês e o espanhol. Cabe ressaltar que o alemão não faz parte do Programa Nacional do Livro Didático (PNLD), assim como o espanhol e o inglês, de modo que não há obrigatoriedade por parte do Estado em ceder tal material desse idioma para as escolas. Nesse sentido, a oferta de LD disponíveis na escola fica a cargo de doações feitas pelo Instituto Goethe, que mantém um acordo de cooperação firmado com a Secretaria de Educação do Estado de São Paulo a fim de oferecer formação continuada aos professores de alemão que atuam nos CEL e, também, material didático específico, entre os quais estão os LD. Dessa forma, os LD disponíveis na escola não podem ser doados para os alunos uma vez que precisam estar disponíveis na escola para o uso durante as aulas.

Vale destacar, ainda, o fato de que muitos alunos não mostram interesse em adquirir ou em ter uma cópia do LD apesar de serem orientados nesse sentido. Como consequência, durante seus estudos, os alunos podem apoiar-se apenas parcialmente neste dispositivo já que não dispõem dele fora dos limites da sala de aula. 
Além disso, minhas primeiras experiências como docente no CEL estudado indicaram que os alunos têm pouca desenvoltura no estudo de LE e por isso apresentam uma série de dificuldades em trabalhar com um LD internacional ${ }^{1}$ que pressupõe algum tipo de autonomia e de desenvoltura para o estudo da LE em questão, além da dificuldade de estudar em casa sem ter esse dispositivo à sua disposição.

Nesse sentido, este trabalho visa preencher uma lacuna existente no que se refere à oferta do curso de alemão nesse contexto específico dos CEL a partir do viés da análise de necessidades. No caso do ensino de alemão nos CEL, esse idioma ainda é deixado à margem de amplas discussões, sobretudo, devido ao prestígio crescente que a língua inglesa assume a partir da publicação da Lei de Diretrizes e Bases (LDB) de 1961, assim como descreve Paiva (2003, p. 56).

Concomitante à publicação desse documento cresce também a crença de que não se aprende LE na escola - ainda de acordo com Paiva (2003) - de modo que, no caso do alemão nos CEL temos a oferta de um idioma que não possui o mesmo prestígio do inglês. Por outro lado, a oferta de alemão nos CEL vai na contramão do que afirma a autora já que, mesmo em se tratando de um curso oferecido dentro do espaço físico de uma escola regular, o curso de alemão tem como objetivo fazer com que o aluno aprenda o idioma de maneira efetiva levando em consideração os níveis do Quadro Europeu Comum de Referência para Línguas.

Contudo, é preciso levar em consideração que os alunos que fazem parte desse curso são provenientes das escolas públicas e podem carregar em si essa visão de que não se aprende LE na escola (cf. OCEM, 2006, p. 8), mesmo frequentando um curso do CEL.

Dessa forma, a análise de necessidades pode aferir a visão dos alunos sobre esse contexto e sobre a oferta do curso de alemão.

Além disso, existem poucos trabalhos que tratam acerca de necessidades no contexto especifico dos CEL, sobretudo, no que tange ao alemão. Godoy (2013) trata sobre o ensino de francês nos CEL sem, no entanto, abordar o aspecto das

\footnotetext{
${ }^{1}$ Livro Didático produzido e publicado por grandes editoras em outros países e distribuído com o intuito de atender ao mercado global. Essa definição será retomada com detalhes na seção 2.3.2.
} 
necessidades ou da presença do LD nesse contexto. Existe ainda o trabalho de Debia e Uphoff (2017) que trata sobre necessidades no caso específico do ensino de língua alemã no contexto universitário e o trabalho de Dutra (2016) sobre o contexto dos CEL no que se refere ao desenvolvimento da autonomia dos estudantes que frequentam os cursos nesses centros.

Com isso, este trabalho fornece espaço para investigar as necessidades dos alunos dos CEL acerca, sobretudo, do que concerne à sua relação com o LD e às expectativas e dificuldades geradas a partir do uso desse dispositivo durante 0 processo de aprendizagem de alemão. 


\section{Referencial teórico}

Neste capítulo apresentarei os pressupostos teóricos utilizados nesta pesquisa. Na primeira seção apresentarei um panorama sobre políticas linguísticas no Brasil de acordo com a LDB e também um resumo sobre os documentos políticos que regem o funcionamento dos CEL seguido por uma discussão sobre o LD assumindo papel de currículo para o curso de alemão dos CEL. Na segunda seção, tanto o termo necessidade quanto os tipos existentes de necessidades são definidos a partir das discussões de Richards (2001) e Weissenberg (2012). A partir dessa discussão, a última seção deste capítulo definirá o termo livro didático de modo a diferenciar este dispositivo dos demais materiais didáticos existentes na aula de LE além de discutir as suas funções de acordo com Neuner (1999) e Maijala (2007). Além disso, também é apresentada uma discussão acerca do LD de modo a apresentar o dispositivo mostrando como ele pode ser relacionado com os tipos de necessidades existentes.

\subsection{Aspectos políticos do ensino de línguas}

Esta seção pretende discutir o histórico do estudo de LE no Brasil a partir de documentos oficiais como a LDB de 1961 e de 1996 para, em um segundo momento, abordar de forma específica a legislação que rege o funcionamento dos CEL desde a sua fundação em 1987. Por fim, será apresentada uma discussão acerca do ensino de alemão nesse contexto a partir da perspectiva da ausência de um currículo que norteia o trabalho.

\subsubsection{O ensino de LE no Brasil: documentos oficiais e contexto}

O estudo de LE já ocorre há um tempo relativamente longo quando se considera, por exemplo, o ensino de línguas como o latim e o grego. Contudo, para 
se entender os moldes atuais em que a oferta de cursos ocorre, é preciso se ater, sobretudo, à publicação de documentos como a LDB - Lei de Diretrizes e Bases da Educação - de 1961. Com isso, não se excluem outras importantes mudanças pelas quais o ensino de LE passou no Brasil, assim como descreve Leffa (1999), no entanto, um apanhado histórico mais abrangente abordaria aspectos inerentes a diversas questões e mudanças que não interessariam diretamente a este trabalho.

A primeira LDB, de 1961, foi a responsável por descentralizar o ensino, dando mais autonomia para estados e municípios. Com a publicação deste documento, o ensino de LE torna-se responsabilidade dos conselhos estaduais de educação. Portanto, esse documento não torna obrigatório o ensino de LE, mas sim, deixa a cargo de estados e municípios decidir se a disciplina é oferecida ou não. Na prática, essa política trouxe algumas mudanças significativas para o ensino e oferta de LE no Brasil: o latim foi retirado do currículo e o francês teve a sua carga horária semanal diminuída (quando não foi retirado do currículo), ao passo que, o inglês sofreu relativamente poucas alterações.

Com isso, de acordo com Leffa (1999), a LDB acabou diminuindo a oferta ao ensino de outros idiomas, além do inglês, no país uma vez que não havia mais a obrigatoriedade legal do ensino de LE. Após a publicação deste documento, algumas mudanças ocorreram aos poucos em relação ao ensino de LE. Algumas instituições aboliram a oferta de LE no $1^{\circ}$ grau e não ofereciam mais do que uma hora de aula semanal, no $2^{\circ}$ grau. Dessa forma, havia alunos que passaram pelo período escolar nesse período sem ter contato com nenhuma LE (cf. LEFFA, 1999, p. 19).

Essa diminuição na oferta está diretamente ligada à criação dos CEL, em 1987, que visava oferecer, inicialmente, a opção para que os alunos pudessem estudar, além do inglês, o espanhol, mesmo que em caráter eletivo.

Com a publicação da LDB de 1996, a nomenclatura antiga é deixada de lado e passam a existir o ensino fundamental e o médio. Neste documento, aparece de forma clara a necessidade de oferecer o ensino de LE para os alunos, de forma que, a partir da quinta série (atual sexto ano), o ensino de pelo menos uma LE moderna se torna obrigatório com uma carga horária semanal equivalente a duas horas aula de 50 minutos cada. 
Complementando a LDB, existem atualmente os PCNs - Parâmetros Curriculares Nacionais, de 1998 para o ensino fundamental II - que tratam acerca do ensino de LE a partir de uma abordagem sociointeracional, com ênfase no desenvolvimento das competências leitoras dos alunos. Vale ressaltar que os PCNs com foco no ensino médio foram originalmente publicados em 1999.

A Lei $N^{\circ} 11.161$, de 2005, torna obrigatório também a oferta do ensino de espanhol no ensino médio. Contudo, a Medida Provisória 746, de 2016, revoga esta lei. Em 2006 surgem as OCEM - Orientações Curriculares para o Ensino Médio que tratam sobre diversos parâmetros a serem seguidos e aos objetivos do ensino de algumas disciplinas.

O projeto da LDB, em sua versão mais recente, de 2017, inclui obrigatoriamente a língua inglesa como componente curricular obrigatório apenas para o ensino médio. A Lei também dispõe o espanhol como língua estrangeira que pode ser oferecida de acordo com a demanda local. O ensino de LE é obrigatório a partir do sexto ano do ensino fundamental, de acordo com o documento: "§5o No currículo do ensino fundamental, a partir do sexto ano, será ofertada a língua inglesa" (LDB Art. 26, parágrafo $5^{\circ}$, p. $20^{2}$ ). A partir de 2017, com a sanção da Reforma do Ensino Médio - com a Medida Provisória 746 -, a língua inglesa é citada nominalmente como sendo obrigatória. Contudo, o texto ainda cita que a oferta de outras LE - de preferência o espanhol - podem ser oferecidas apesar de não deixar claro como isso pode ser feito:

4o Os currículos do ensino médio incluirão, obrigatoriamente, o estudo da língua inglesa e poderão ofertar outras línguas estrangeiras, em caráter optativo, preferencialmente o espanhol, de acordo com a disponibilidade de oferta, locais e horários definidos pelos sistemas de ensino. (LDB Art. $35 \mathrm{~A}$, parágrafo $4^{\circ}$, p. 25)

Dessa forma, talvez a iniciativa dos CEL busque preencher a lacuna deixada no sentido de oferecer a possibilidade dos alunos estudarem outras LE que normalmente não seriam ofertadas no ensino regular.

\footnotetext{
${ }^{2}$ Disponível em: http://www2.senado.leg.br/bdsf/bitstream/handle/id/529732/lei_de_diretrizes_e bases_1ed.pdf (consultado em 01/08/2018)
} 
Assim, agora que o histórico geral do ensino de LE no Brasil e os documentos publicados ao longo dos anos foram apresentados, a próxima seção abordará o caso específico dos CEL no estado de São Paulo quanto à publicação de documentos oficiais que regem seu funcionamento.

\subsubsection{Documentos oficiais que regem o funcionamento do CEL}

No meio escolar, muitas vezes as regras e procedimentos de funcionamento das instituições são aprendidas ou, ainda, apenas depreendidas, na prática, uma vez que não são criados espaços para a discussão de determinadas regras que regem o funcionamento das escolas.

Além disso, a própria profissão de professor é encarada muitas vezes como sendo algo que depende em grande medida de conhecimento prático que se adquire ao longo da carreira docente (cf. CELANI, 2001). Da mesma forma, alguns aspectos que estão presentes no cotidiano escolar quanto aos trâmites legais que envolvem diretamente o trabalho pedagógico são encarados com naturalidade por aqueles que estão diretamente envolvidos neste trabalho sem que haja, no entanto, um momento para explicações ou reflexões acerca da prática que se faz e a sua razão de existir.

Dito de outra maneira, assim como a profissão de professor exige estudo e preparo e não depende apenas de aptidão, também a parte burocrática do funcionamento de uma instituição de ensino deve ser estudada e compreendida já que, mesmo que de forma indireta, pode, sim, afetar o trabalho docente. Além disso, os próprios alunos também estão inseridos nesse contexto e, de certa forma, sofrem as consequências de toda a estrutura burocrática que rege o funcionamento dos cursos.

Dessa forma, pensando especificamente no contexto dos CEL, há uma série de normas que regem o curso e que não são estabelecidas pela coordenação ou pela gestão da escola que abriga essas instituições. Todas essas regras estão devidamente regulamentadas pelo Decreto $\mathrm{N}^{\circ}$ 27.270, de 10 de Agosto de 1987, 
que trata da criação dos CEL seguido por mais oito resoluções publicadas ao longo desses mais de 30 anos em que a iniciativa existe.

Em geral, cada resolução é feita com base na anterior e, sempre que há algo novo ou algo que precisa ser acrescentado ao texto vigente, surge uma nova resolução, a qual, por sua vez, modifica ou anula a anterior.

Assim, ao ler os textos de cada uma das resoluções, nota-se que, inicialmente, o objetivo dos CEL era oferecer principalmente o curso de espanhol em caráter opcional para alunos que estivessem devidamente matriculados nas escolas públicas do estado de São Paulo:

Artigo 1.․ - Ficam criados, no âmbito da rede estadual de ensino, Centros de Estudos de Línguas que terão por finalidade proporcionar aos alunos das escolas públicas estaduais uma possibilidade diferenciada de aprendizagem de várias línguas estrangeiras modernas, com prioridade para língua espanhola.

Parágrafo único - A criação dos Centros de Estudos de Línguas faz parte de um conjunto de medidas visando modificação e enriquecimento da grade curricular da escola estadual de $1 .^{\circ}$ e $2 .^{\circ}$ graus, no que se refere ao ensino de línguas estrangeiras modernas. (Decreto SE N. 27.270, DE 10 DE AGOSTO DE 1987)

Ao longo dos anos, o oferecimento prioritário do curso de espanhol foi alterado de modo que as unidades do CEL, de acordo com a demanda, pudessem oferecer outros cursos. Nesse sentido, em 1988, um ano após a criação dos Centros, foi publicada uma resolução na qual a prioridade da língua espanhola termina, haja vista o fato de que, de acordo com a resolução SE № 193, de 18 de Agosto de 1988, a partir daquele momento, os CEL deveriam oferecer preferencialmente aulas de espanhol, mas não apenas dessa língua como indicava a resolução SE N²71 de 20 de Novembro de 1987:

Artigo $1^{\circ}$ - O parágrafo único do artigo $1^{\circ}$ da Resolução SE 271, de 20-1187 , passa a vigorar com a seguinte redação:

"Parágrafo único - No primeiro ano de funcionamento, o Centro proporcionará, preferencialmente, o ensino de língua espanhola". (SE SE Nº 193 DE 18 DE AGOSTO DE 1988. Aspas no original)

Nas resoluções existem indicações sobre organização, como número de horas e quantidade de estágios, contratação de professores e de coordenadores pedagógicos, bem como sobre a nomeação e a implantação dos CEL. 
Além dos dados descritos, as resoluções que tratam acerca dos CEL nomeiam diretamente alguns idiomas ao longo de seu texto. Nesse sentido, línguas como o espanhol, o inglês e o francês são mencionadas de forma explícita, ao passo que o alemão não é citado em nenhuma das resoluções publicadas:

\begin{abstract}
"Artigo $1^{\circ}$ - O ensino de língua estrangeira moderna, inglês, espanhol ou francês, aos alunos da rede pública estadual, poderá ser ministrado por instituição credenciada para esse fim, desde que esgotadas as possibilidades de atendimento da demanda pelos Centros de Estudos de Línguas - CELs" (SE Nº 33 de 23 de Março de 2010. Aspas no original)
\end{abstract}

Assim, tanto estrutura, quanto outros aspectos burocráticos que envolvam a oferta da língua alemã nos CEL vão ser orientados por disposições legais feitas para os demais cursos nomeados de forma explícita nos documentos citados.

As resoluções também apontam para a firmação de convênios entre instituições de renome que possam contribuir para a oferta de determinado idioma no contexto do CEL. No caso específico da língua alemã, há um acordo de cooperação entre a Secretaria da Educação do Estado de São Paulo e o Instituto Goethe, que possibilita aos professores a participação em orientações técnicas regulares além da possibilidade de fazer parte de cursos de aprimoramento, inclusive na Alemanha, e, aos alunos do CEL, a possibilidade de realizar provas de proficiência oficiais para a obtenção de certificados internacionais. Além disso, o acordo também estabelece a doação de materiais para serem utilizados durante as aulas nos CEL, incluindo os exemplares do LD que ficarão disponíveis na escola.

Apesar de bastante abrangentes, as resoluções não abordam aspectos como, por exemplo, a escolha do LD que é adotado durante as aulas e nem os critérios utilizados para que essa escolha seja feita. Cabe ressaltar que a última resolução que trata acerca do funcionamento dos CEL foi publicada em 04 de julho de 2018 (Resolução SE 43/2018) e trata sobre a quantidade mínima e máxima de alunos por turma e sobre os critérios que devem ser levados em consideração para a formação de turmas multisseriadas.

Assim como já foi indicado, a própria estrutura dos cursos do CEL é descrita nas resoluções publicadas. Desse modo, a próxima seção apresenta essa estrutura a partir dos documentos oficiais e também a partir da pesquisa de Godoy (2013). 


\subsubsection{A estrutura dos cursos nos CEL}

Todos os alunos devidamente matriculados na rede pública de ensino a partir do $7^{\circ}$ ano do ensino fundamental, bem como alunos matriculados em cursos oferecidos pelo Centro Paula Souza e alunos com mais de 18 anos que façam parte de algum programa de Educação de Jovens e Adultos (EJA) também vinculado à rede pública, têm direito de frequentar os cursos oferecidos pelos diversos CEL existentes.

No ato da matrícula, o aluno pode optar por até dois cursos diferentes de acordo tanto com a sua disponibilidade de tempo, quanto com a disponibilidade de horários oferecidos pela escola que abriga as instalações do CEL. Por isso, é comum que existam alunos que frequentem dois cursos diferentes. Muitas vezes, os alunos iniciam dois cursos ao mesmo tempo visando terminá-los concomitantemente já que, em geral, a duração dos cursos é a mesma.

Os CEL sempre são implantados em uma escola pública estando ligados a essa escola tanto pedagógico, quanto administrativamente. Dessa forma, não pode haver um CEL funcionando de forma independente já que este divide espaço com uma escola de ensino regular. Porém, apesar de estarem vinculados e de serem obrigados a respeitar o calendário escolar e o regimento da escola sede, os CEL têm certa autonomia para organizar horários, turmas, disponibilidade de salas e eventos.

Todos os cursos oferecidos por essas instituições, exceto o curso de inglês, possuem a mesma organização e carga horária. O curso todo tem duração de 400 horas divididas em dois módulos que, por sua vez, são divididos em três níveis ou estágios. Cada um dos estágios, que correspondem a um semestre de aulas, deve conter 80 aulas de 50 minutos cada. Assim, cada módulo corresponde a três estágios, de maneira que o curso completo pode ser concluído em três anos como demonstra a figura proposta por Godoy (2013, p. 23): 


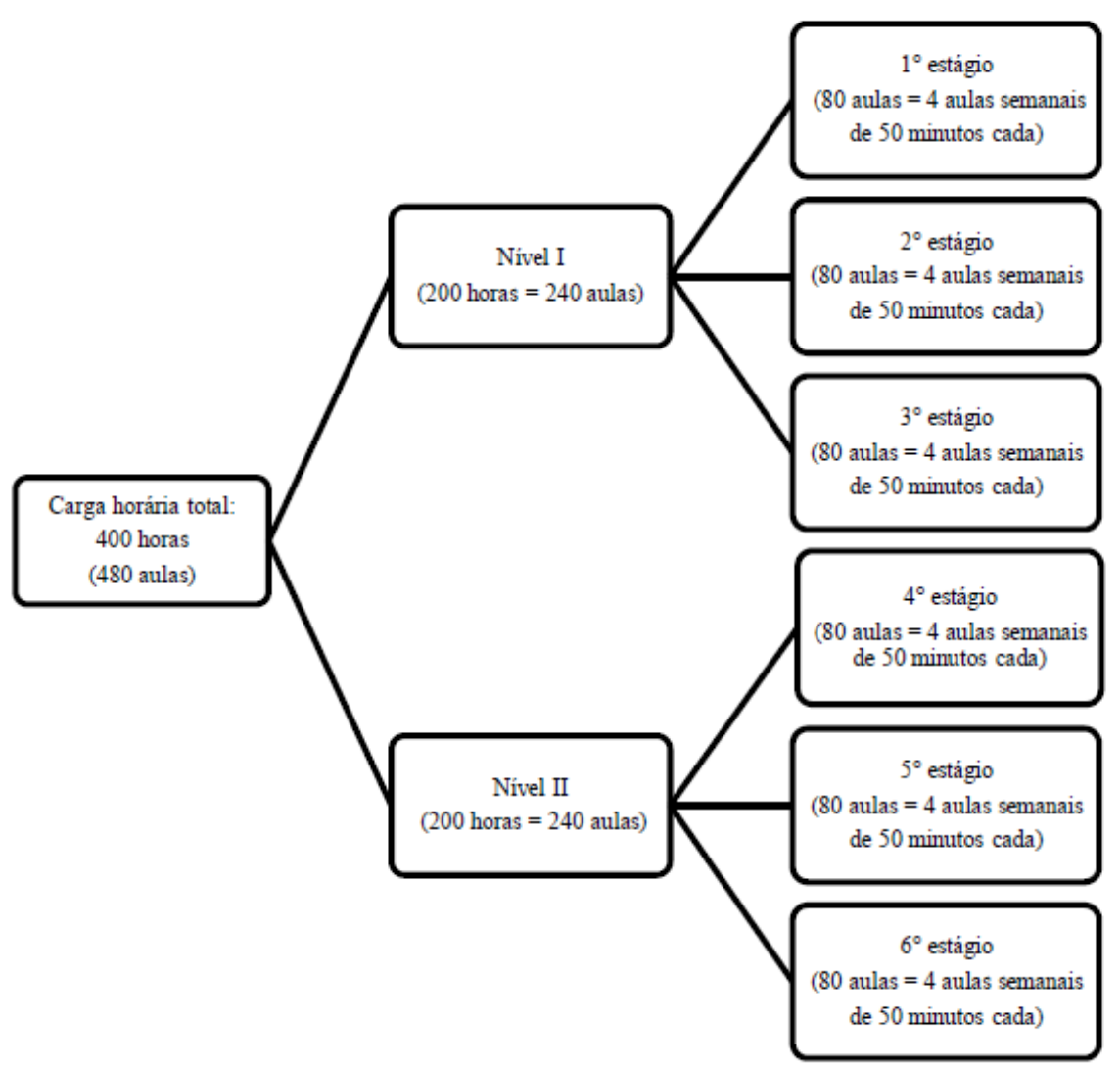

Figura 1: organograma dos cursos do CEL

Em relação às turmas, vale ressaltar que cada uma delas deve ser composta de pelo menos 25 e ter, no máximo, 35 alunos, no entanto, é possível que a escola mantenha turmas com um número inferior a 25 caso a turma esteja no último estágio do curso. Além disso, casos especiais são analisados pela Diretoria de Ensino Regional à qual a escola sede do CEL responde. Em caso de existirem turmas com um número reduzido de alunos, há a possibilidade de formar turmas multisseriadas.

De forma mais abrangente, o LD também faz parte do quadro organizacional dos cursos de alemão nos CEL, uma vez que o dispositivo atua na estrutura apresentada na Figura 1 passando a funcionar como o elemento que, no âmbito dos CEL, organiza tal estrutura quanto aos conteúdos e quanto à sua progressão. Mesmo assim, o LD não é citado nas resoluções que regem o funcionamento dos CEL - assim como já foi discutido anteriormente - e, em geral, as consequências dessa atuação do LD não são discutidas amplamente, mas sim, tratadas com normalidade. 
Assim, a partir das considerações feitas, nota-se que o LD muitas vezes assume outros papéis que ultrapassam as fronteiras de um dispositivo estritamente pedagógico. Desse modo, a próxima seção discute o papel assumido pelo LD em um contexto, como o do ensino de alemão nos CEL, no qual não há um currículo claro norteando os cursos.

\subsubsection{Alemão nos CEL: currículo e LD}

No caso específico dos CEL, assim como já foi discutido na seção anterior, o funcionamento e a oferta dos cursos obedecem às disposições legais dispostas nas resoluções publicadas ao longo dos anos desde que os Centros foram criados. No entanto, existe um fator ainda pouco explorado que se relaciona com a grande organização de curso em relação aos conteúdos e à progressão dos conteúdos nesse contexto.

Como foi visto na seção 2.1.1., existem alguns documentos que tratam sobre o ensino de LE no Brasil, como é o caso da LDB, das OCEM e dos PCNs, porém, durante a observância de todos os documentos existentes, nota-se que ainda há a falta de um currículo específico que trate sobre o ensino de alemão.

De acordo com Bimmel et al. (2011), ao analisar o contexto de ensino de línguas (no contexto alemão), existem os seguintes tipos de documentos passíveis de análise:

1. Plano de ensino ("Lehrplan”): possui uma série de indicações gerais para os princípios comuns das aulas em geral e, além disso, tratam sobre as divisões dos conteúdos por série e, inclusive, podem indicar quantas aulas são necessárias durante uma semana ou ano, por exemplo. Em outras palavras, planos de ensino são desenvolvidos por órgãos oficiais como ministérios, por exemplo, e indicam aquilo que os professores precisam saber e o que as escolas precisam ensinar.

2. Parâmetros Curriculares ("Rahmenrichtlinien”): fazem indicações sobre algum nível específico como ensino fundamental ou médio e dão 
instruções gerais e fundamentos para a realização das aulas. Os parâmetros curriculares tratam as disciplinas de maneira geral e servem de parâmetro para a elaboração de currículos escolares.

3. Currículo ("Curricula"): tem relação com as bases de cada uma das disciplinas do sistema educacional de um país e busca dar bases didáticas e metodológicas para essas disciplinas.

Neste ponto, é importante ressaltar que os autores abrem espaço para que os professores analisem se realmente há esses três aspectos em suas realidades (cf. BIMMEL et al., 2011, p. 16). No caso específico dos CEL, existem alguns documentos oficiais responsáveis por reger seu funcionamento burocraticamente e pedagogicamente que podem ser enquadrados nos conceitos acima descritos.

Os decretos e resoluções publicados desde o surgimento da iniciativa em 1987 podem ser classificados como Rahmenrichtlinien devido ao fato de não serem ricos em detalhes e, por isso, tratarem de forma geral sobre as aulas nesses centros. Junto aos documentos oficiais citados, estão também os PCNs que, da mesma forma, dão instruções gerais de como as aulas de língua estrangeira deveriam ser realizadas sem que, no entanto, alguma particularidade seja tratada.

No âmbito das escolas, existe ainda um documento chamado de Projeto Político Pedagógico (PPP) que contém orientações gerais e normas para cada escola. Assim, uma vez que os CEL são vinculados às escolas de ensino regular, a sua proposta precisa constar do PPP da escola à qual esse Centro está vinculado. Nesse sentido, por ser um documento elaborado por uma instituição e por indicar princípios comuns que regem as aulas nesta instituição, o PPP poderia ser enquadrado também como Lehrplan, de acordo com terminologia de Bimmel et al. (cf. 2011, p. 16). Vale ressaltar que o CEL que abrigou a pesquisa possui um PPP, no entanto, não foi possível ter acesso ao documento, mesmo após inúmeras tentativas junto à equipe gestora.

Com isso, nota-se que ainda não há nos CEL um currículo específico disponível para a língua alemã que estabeleça as bases didático-metodológicas para o ensino desse idioma de modo que, a partir dos documentos existentes, cabe ao professor a tarefa de adequar as indicações gerais existentes para a elaboração e realização das aulas. 
Nesse sentido, a falta de um currículo eleva o LD a um patamar extremamente relevante já que, na ausência desse documento, o próprio LD assume o papel de organizar conteúdos, temas e a ordem em que eles aparecerão no curso. Assim, nota-se que o LD é um dispositivo cercado por diversos fatores que fazem com que ele adquira outras funções que, a priori, deveriam ser ocupadas por outros elementos.

Vale ressaltar que já foi formulado um currículo de língua alemã que foi desenvolvido levando em consideração o contexto específico dos CEL, porém, até a data de entrega deste trabalho, o mesmo ainda não havia sido publicado.

\subsection{Análise de necessidades}

Ao abordar o termo "necessidades" é preciso levar em consideração as várias acepções que podem ser atribuídas a ele. No caso da língua alemã, existem duas palavras para designar o que em português seriam necessidades. Por um lado, a palavra Bedarf designa um tipo de necessidade ligada a leis, currículos ou regras específicas de instituições de ensino, por exemplo, quando do desenvolvimento e implantação de cursos. Por outro lado, existe a palavra Bedürfnis, que designa necessidades vinculadas diretamente aos aprendizes que trazem consigo expectativas sobre a sua aprendizagem (cf. PEUSCHEL, 2008, p. 33).

Apesar de diferentes, necessidades objetivas, Bedarfe, e necessidades subjetivas, Bedürfnisse, têm alguma relação já que estas são permeadas pela presença daquelas quando se trata de um curso oferecido em uma instituição de ensino.

Assim, este capítulo pretende definir o termo "análise de necessidades" a partir dos estudos de Richards (2001) e mostrar os três tipos de necessidades existentes de acordo com a definição proposta por Weissenberg (2012) destacando, sobretudo, as necessidades subjetivas e processuais que são o foco deste trabalho. 


\subsubsection{Definição e propósitos da análise de necessidades}

O procedimento de coletar dados para o desenvolvimento de currículos educacionais na área de aprendizagem de língua estrangeira ocorre desde a década de 1960 quando surgiu a demanda por programas de ensino especializados. Nesse sentido, de acordo com Richards, os "procedimentos usados para coletar informação sobre os aprendizes são conhecidos como análise de necessidades ${ }^{3 \prime \prime}$ (2001, p. 51, tradução minha $\left.{ }^{4}\right)$. Para o autor, o desenvolvimento de qualquer programa educacional deveria ter como premissa a análise das necessidades dos aprendizes envolvidos diretamente com o curso a fim de que este possa atender às expectativas desses aprendizes de maneira eficaz.

Ainda sobre o termo necessidade, Richards, citando Brindley (1984, p. 28) aponta para o fato deste ser comumente utilizado para designar "desejos, expectativas, motivações, carências, restrições e exigências" (2001, p. 54). O fato de haver diversas palavras utilizadas para o termo necessidade demonstra a complexidade desse termo e aponta para o fato de que nem sempre é fácil determinar quais necessidades serão analisadas.

Em geral, aplicando o conceito de necessidade para o contexto de aprendizagem de língua estrangeira, verifica-se um panorama no qual o termo determinaria deficiências linguísticas relacionadas ao que os aprendizes são capazes de fazer no momento em comparação com o que eles deveriam ser capazes de fazer. No entanto, a subjetividade do termo implica que uma necessidade só pode ser identificada como tal após ser avaliada e julgada a partir de valores e interesses daqueles que farão esse julgamento (cf. RICHARDS, 2001, p.54).

Após identificar uma necessidade, é possível notar que a análise pode ser utilizada para uma série de propósitos, como aponta Richards (2001, p.52):

- Descobrir quais competências linguísticas um aprendiz necessita para desempenhar um papel específico como gerente de vendas, guia turístico ou estudante universitário;

\footnotetext{
${ }^{3}$ No original: "Procedures used to collect information about learners' needs are known as needs analysis".

${ }^{4}$ A grande maioria das traduções deste trabalho será de minha autoria. As exceções serão identificadas.
} 
- Ajudar a determinar se um curso existente direciona adequadamente as necessidades de potenciais estudantes;

- Determinar quais estudantes de um grupo têm mais necessidade de treinar competências linguísticas em particular;

- Identificar uma mudança de direção que pessoas em um grupo de referência consideram importante;

- Identificar uma lacuna entre o que estudantes são capazes de fazer e o que eles precisam ser capazes de fazer;

- Coletar informação sobre um problema particular que os alunos estão vivenciando. $^{5}$

Ainda tratando sobre o estudo de Richards, vale ressaltar que o autor deixa claro que a análise de necessidades inclui o estudo tanto de necessidades percebidas quando de necessidades não percebidas (cf. RICHARDS, 2001, p. 53). Cabe observar que há aqui uma lacuna nos estudo de Richards já que o autor, apesar de indicar que existem tipos diferentes de necessidades, não deixa claro quem seria o responsável por percebê-las ou não:

O que se identifica como uma necessidade depende do julgamento e reflete os interesses e valores daqueles que fazem tal julgamento. Professores, alunos, empregadores, pais e outros interessados podem, portanto, ter diferentes pontos de vista acerca do que são necessidades ${ }^{6}$. (RICHARDS, 2001, P.54.)

Nesse sentido, verificando a existência de diferentes tipos de necessidades ainda não claramente classificadas por Richards, surge a classificação proposta por Weissenberg (2012) que, além de preencher a lacuna deixada por Richards, ainda define quais são os tipos existentes de necessidades e suas especificidades.

Dessa forma, a próxima seção trata sobre os tipos existentes de necessidades de acordo com Weissenberg (2012) que, além de retomar alguns conceitos importantes descritos por Richards, desenvolve esses conceitos já que o autor define e separa claramente três tipos de necessidades, diferente de Richards que apenas aponta necessidades percebidas e necessidades não percebidas.

\footnotetext{
${ }^{5}$ No Original: "To find out what language skills a learner needs in order to perform a particular role, such as sales manager, tour guide, or university student/ To help determine if an existing course adequately addresses the needs of potential students/ To determine which students from a group are most in need of training in particular language skills/ To identify a change of direction that people in a reference group feel is important/ to identify a gap between what students are able to do and what they need to be able to do/ To collect information about a particular problem learners are experiencing".

${ }^{6}$ No original: "What is identified as a need is dependent on judgement and reflects the interests and values of those making such a judgment. Teachers, learners, employers, parents, and other stakeholders may thus all have different views as to what needs are".
} 


\subsubsection{Tipos de necessidades}

Mesmo tratando apenas sobre o estudo de alemão como segunda língua (DaZ) e enfocando aspectos profissionais para exemplificar suas analises, Weissenberg (2012) de certa forma amplia os estudos já citados de Richards (2001) na medida em que ele trata não apenas do que deve ser observado quando se fala em necessidades, mas também sobre quais seriam essas necessidades.

Nesse sentido, o autor inicia suas considerações afirmando que ao preparar um curso, é preciso levar em consideração três aspectos: os objetivos, os temas e os meios ou métodos utilizados (cf. WEISSENBERG, 2012, p.9). Após apresentar e explorar cada um desses aspectos, Weissenberg diz que de acordo com o contexto é possível notar três tipos de necessidades: as necessidades orientadas pelo produto (necessidades objetivas), as necessidades orientadas pelos aprendizes (necessidades subjetivas) e as necessidades processuais (necessidades de aprendizagem).

O primeiro tipo de necessidade, as necessidades orientadas pelo produto, ou objetivas, tem uma estreita relação com instâncias externas à sala de aula e liga-se, portanto, a leis ou determinações oficiais em uma escala mais abrangente ou, ainda, a currículos ou regimentos internos de determinada instituição de ensino que abriga o curso (como discutido na seção 2.1.4.), assim como aponta Weissenberg:

Necessidades orientadas pelo produto, isto é, necessidades objetivas, designam necessidades linguísticas que os próprios professores identificam ou podem apurar a partir de uma investigação dos objetivos profissionais ${ }^{7}$ e das respectivas exigências comunicativas, assim como a partir da observância das exigências linguísticas e experiências profissionais dos participantes do curso. Para isso são levados em consideração também, sobretudo, as expectativas de outros participantes (como agência de emprego, empresa, instituições de apoio à formação, etc.) Necessidades objetivas baseiam-se em informações objetivas e servem para a descrição dos objetivos da aula ${ }^{8}$. (2012, p. 9)

\footnotetext{
${ }^{7}$ Weissenberg focaliza seu trabalho no ensino de DaZ, por isso existe a recorrência em tratar sobre o contexto profissional dos alunos.

${ }^{8}$ No original: „Produktorientierte bzw. objektive Bedarfe nennt man Sprachbedarfe, die Kursleitende selbst aufgrund einer Untersuchung der beruflichen Zielsituationen und deren kommunikativen Anforderungen sowie unter Berücksichtigung der sprachlichen Voraussetzungen und beruflichen Erfahrungen der teilnehmenden erkennen bzw. festellen können. Dabei werden insbesondere auch die Erwartungen anderer Beteiligter (wie
} 
Nesse sentido, as necessidades objetivas atuam muitas vezes como pano de fundo para a análise de outro tipo de necessidades já que, a partir de alguma situação determinada pela observância das necessidades objetivas, podem surgir aspectos relevantes dentro dos limites da sala de aula, quando da observância das necessidades dos alunos, as necessidades subjetivas.

Em outras palavras, determinações ou orientações oficiais feitas em larga escala podem influenciar, mesmo que indiretamente, as necessidades próprias dos aprendizes que se deparam com determinado contexto.

Por sua vez, as necessidades orientadas pelos aprendizes, chamadas de necessidades subjetivas, têm relação, não com instâncias externas, mas sim com as necessidades dos próprios aprendizes que participam de algum curso e em geral são descritas como necessidades expressas ou observadas pelos próprios aprendizes e que podem ser muito amplas, já que podem envolver diversos fatores que envolvem o processo de aprendizagem dos alunos, desde materiais didáticos até a Sozialform mais adequada para algum tipo de atividade durante a aula. Observando as considerações feitas por Weissenberg (2012, p. 10), nota-se que esse tipo de necessidade é descrito como:

Como necessidades orientadas pelos aprendizes, isto é, necessidades subjetivas designam-se necessidades linguísticas que os próprios participantes de um curso manifestam, ou, formulam. ${ }^{9}$

O último tipo de necessidade refere-se às necessidades que os professores notam dos aprendizes em relação às habilidades linguísticas e também levando em conta os materiais utilizados para a aula e as condições do local onde essa aula ocorre. Desse modo, de acordo com Weissenberg:

Necessidades processuais, isto é, necessidades voltadas para o processo de aprendizagem, são necessidades linguísticas que os professores identificam com base nas habilidades metódicas dos participantes do curso,

\footnotetext{
Jobcenter, Betrieb, Bildungsträger etc) beachtet. Objektive Bedarfe beruhen auf Sachinformationen und dienen der Beschreibung der Unterrichtsziele."

9 No original: „Als lernerorientierte bzw. subjektive Bedarfe bezeichnet man Sprachbedarfe, die die Kursteilnehmenden selbst äußern bzw. formulieren“.
} 
assim como através da observância das condições espaciais e materiais do curso. Necessidades voltadas para o processo de aprendizagem dão ainda uma indicação para a mediação de competências metódicas e de possíveis estratégias de aprendizagem ${ }^{10}$. $(2012$, p. 11)

Cabe ressaltar que, mesmo que tratadas de forma separada, todos os três tipos de necessidades descritas por Weissenberg têm alguma ligação entre si. Em geral, ao se realizar a análise de apenas um dos tipos de necessidade, é necessário levar em consideração que os outros dois tipos também estarão presentes de alguma forma. Assim, a partir da definição de Weissenberg, cabe definir os elementos que serão analisados neste trabalho de acordo com o tipo de necessidade que está em foco.

Em relação ao próprio LD como dispositivo utilizado nas aulas, é possível aferir que o mesmo perpassa mais de um dos tipos de necessidades de Weissenberg. No entanto, antes de aprofundar essa discussão, na seção 2.3.3., é preciso esclarecer o que é um LD e como ele se diferencia de outros materiais utilizados nas aulas. Para isso, a próxima seção tratará exclusivamente sobre o papel do LD nas aulas de LE.

\subsection{Livro didático}

Esta seção trata sobre o LD enquanto dispositivo utilizado no contexto de ensino-aprendizagem de LE. Primeiramente, será apresentada a definição do termo livro didático em comparação com outros materiais utilizáveis nas aulas de LE. Na segunda parte, os tipos de LD serão apresentados com uma breve discussão sobre a utilização desse dispositivo no contexto brasileiro. Por fim serão apresentadas as funções desse dispositivo nas aulas, seguidas por uma argumentação acerca do LD em relação às necessidades de Weissenberg que foram expostas na seção anterior.

\footnotetext{
${ }^{10}$ No original: „Prozessorientierte Bedarfe bzw. Lernbedarfe sind Sprachbedarfe, die der/ die Kursleitende auf der Basis der methodischen Fertigkeiten der Teilnehmenden sowie unter Berücksichtigung der vorhandenen räumlichen und materiellen Rahmenbedingungen des Kurses feststellt. Lernbedarfe geben einen Hinweis auf noch zu vermittelnde methodische Kompetenzen und auf mögliche Lernstrategien“.
} 


\subsubsection{Definindo o termo "livro didático"}

No contexto do ensino de LE, o LD figura como o material com o qual os aprendizes têm mais contato durante seus estudos de modo que, em geral, os termos material didático e livro didático chegam a ser entendidos como sinônimos assim como aponta Tomlinson (2011, p. 2). Apesar de tal aproximação, é possível aferir que os termos não podem ser utilizados como sinônimos.

De maneira ampla, segundo Tomlinson, o termo "material didático" refere-se a "tudo que é usado por professores ou alunos para facilitar o aprendizado de uma língua ${ }^{11 "}$ (TOMLINSON, 2011, p. 2). Assim, ao aproximar LD e material didático, exclui-se o fato de que no contexto de ensino-aprendizagem de LE existem diversos elementos passíveis de utilização para fins didáticos. Nesse sentido, até mesmo um texto devidamente manipulado e que sirva a fins didáticos pode ser entendido como um material didático.

A partir desse contexto e, levando em conta a manipulação de diversos materiais para fins didáticos, Rösler (2012) define material didático como todo tipo de material adaptado, escolhido ou produzido a partir de um ponto de vista didático e que trata acerca de fenômenos linguísticos durante a aula (cf. RÖSLER, 2012, p. 41). Dessa forma, o termo se torna muito amplo e passa a abranger uma série de outros elementos como CDs, DVDs, cartazes, mapas e tudo que se pode utilizar com fins didáticos.

A partir do quadro exposto, o LD passa a ser entendido como sendo um dispositivo entre os diversos materiais existentes e passíveis de utilização no contexto de ensino-aprendizagem de LE. Notando essa característica, cabe diferenciá-lo dos demais. Para isso, de acordo com Uphoff (2009, p. 60), o LD

Se distingue de outros tipos de materiais por dois aspectos fundamentais: em primeiro lugar, pela ordem que estabelece em relação à distribuição dos conteúdos na linha do tempo e, além disso, pela extensão dos processos de ensino aprendizagem que o dispositivo pretende cobrir.

\footnotetext{
${ }^{11}$ No original: "anything wich is used by teachers or learners to facilitate the learning of a language".
} 
A partir da citação, nota-se que o LD é um dispositivo que estabelece um certo tipo de ordem em relação aos temas e conteúdos que serão aplicados ao longo do curso de modo a atuar algumas vezes como o principal elemento organizador do curso quando não há, por exemplo, um currículo que exerça essa função. Quanto a esse aspecto, haverá uma discussão acerca de currículos e o papel do LD no contexto do ensino de alemão na seção 2.3.3.

Além de organizar a macroestrutura do curso quanto aos conteúdos, o LD também apresenta a ordem e a maneira como os conteúdos serão aplicados de modo que o dispositivo passa a definir a própria progressão do processo de ensinoaprendizagem.

Ainda de acordo com Uphoff, os diversos materiais didáticos podem ser diferenciados de acordo com a sua função no ensino de línguas (cf. UPHOFF, 2009, p. 57). No caso específico da área de $D a F$, existe a diferenciação feita entre materiais de curso e materiais de apoio ("Kurstragende Materialien" e "Kursbegleitende Materialien" respectivamente) (cf. RÖSLER, 2012, p. 73). Assim, o LD e todos os elementos que o compõem classificam-se como materiais de curso. Por outro lado, gramáticas, dicionários, livros de leitura diversos e outros recursos classificam-se como materiais de apoio.

Vale ressaltar que, além da diferenciação estabelecida pelos termos em alemão quando se distinguem os materiais de apoio e os materiais de curso, existe também em alemão a diferenciação entre Lehrbuch - que é o livro usado durante as aulas - e Lehrwerk - que é o conjunto formado pelo livro de curso e os seus periféricos.

Em português, o termo livro didático é geralmente utilizado de maneira ampla para designar tanto o livro de curso, utilizado durante as aulas, quanto os outros elementos que compõem o conjunto formado, pelo menos, pelo livro de curso e todos os seus periféricos como o livro de exercícios, o manual do professor e recursos audiovisuais.

No caso do ensino de alemão, a maioria dos LD utilizados são produzidos por grandes editoras alemãs. No entanto, tendo em vista que esse LD produzido na Alemanha para ser utilizado em escala mundial é apenas um dos tipos existentes de 
LD, a próxima seção aborda os tipos existentes de LD e traz uma breve discussão sobre o contexto brasileiro.

\subsubsection{Tipos de livro didático}

Como já foi apontado, no Brasil existe a presença em grandes proporções de LD internacionais produzidos por editoras alemãs para o mercado mundial, já que não há atualmente no Brasil uma produção expressiva de LD de alemão que atenda às demandas específicas do nosso contexto.

Antes de iniciar uma discussão acerca das implicações da adoção de LD internacionais é preciso definir claramente o que são esses LD em comparação com outros tipos de LD.

Uphoff (2009) defende que seja possível diferenciar os LD de acordo com o "raio de difusão que o material pretende alcançar" (2009, p. 80). Nesse sentido, é possível distinguir os LD em três tipos: os LD internacionais - produzidos por grandes editoras para o mercado global, as produções regionais - elaboradas a partir de LD internacionais e, ainda, produções nacionais.

Quanto ao primeiro tipo, o LD internacional, Tomlinson (2011) defende que esse material constitui:

\footnotetext{
Um livro didático que não é escrito para aprendizes de uma cultura ou um país específico, mas que se destina ao uso por qualquer grupo de aprendizes de um certo nível de proficiência e de uma certa faixa etária em qualquer lugar do mundo ${ }^{12}$. (2011, p. xii)
}

Seguindo a linha de raciocínio de Uphoff, o fato de possuir uma configuração genérica faz com que o LD internacional não consiga se adequar completamente ao perfil de todos os aprendizes já que para cada contexto, há tipos diferentes de expectativas, ou necessidades. No entanto, a adoção do LD internacional figura

\footnotetext{
${ }^{12}$ No original: "A coursebook which is not written for learners from a particular culture or country but which is intended for use by any class of learners in the specific level and age group anywhere in the world". (Tradução de Uphoff, 2009)
} 
como uma tentativa de encontrar um "denominador comum mínimo para o maior número possível de situações ao redor do mundo" (UPHOFF, 2009, p. 80).

O fato de não atenderem completamente às necessidades dos aprendizes de todas regiões do planeta levou, sobretudo a partir de críticas ao LD internacional nos anos 80 assim como descreve Uphoff (2009), a uma tentativa de regionalizar os LD internacionais para que as demandas mais particulares pudessem ser atendidas.

Nesse sentido, Breitung e Lattaro (2001) definem os materiais regionais como sendo dispositivos que são

Desenvolvidos com base em livros didáticos supra-regionais, produzidos nos países de língua alemã, são adaptados e vão de encontro às necessidades e tradições de ensino específicas de um país [ou] de uma região $^{13}$. (BREITUNG/ LATTARO, 2001, p. 1043, apud UPHOFF, 2009, p. 81)

No contexto brasileiro, não há produção significativa de materiais regionais assim como ocorre em países do leste europeu, por exemplo (cf. UPHOFF, 2009, p. 82). Aqui, o que ocorre é, sobretudo, a produção de glossários bilíngues ou, ainda, a tradução de enunciados, que não afeta os conteúdos ou procedimentos didáticos que foram inicialmente propostos pelo material original.

Quanto à produção nacional, muito pouco foi feito na tentativa de elaborar LD que atendessem exclusivamente ao mercado brasileiro e, talvez devido ao fato da adoção de LD internacionais ser amplamente difundida, não há muitos exemplares produzidos no país de forma que, aqui, destacam-se apenas poucas produções.

Um desses materiais, "Deutsch für Brasilianer" (1988/2006) foi elaborado pelo Prof. Dr. Hans Andreas Welker, da Universidade de Brasília - UnB - e foi adotado por algum tempo apenas no curso da própria universidade (cf. UPHOFF, 2009, p. 83). O segundo material é um LD produzido pela Profa. Dra. Ruth Bohunovsky sob orientação da Profa. Dra. Carmen Zink Bolognini e que ainda não

\footnotetext{
${ }^{13}$ No original: „[Unter regionalen Lehrwerken versteht man im allgemeinen solche,] die auf der Basis überregionaler, im deutschsprachigen Raum entwickelter Lehrwerke den speziellen Bedürfnissen und den Lerntraditionen eines Landes, einer Region angepasst wurden und nunmehr Rechnung tragen“. (Tradução de Uphoff, 2009)
} 
foi publicado, o livro também se intitula "Deutsch für Brasilianer" e terá subtítulos que o diferenciem da obra de Welker (1988/ 2006).

A partir do contexto apresentado e levando em conta a ampla adoção de LD internacionais, Bohunovsky (2009) aponta que a produção de LD de LE tem se tornado um mercado muito rentável nos países de língua alemã de modo que cada vez mais as grandes editoras (Langenscheidt, Cornelsen, Klett e Hueber) produzem livros para distribuir pelo globo. Recentemente, o segmento de ALE da editora Langenscheidt foi incorporado à editora Klett, aumentando ainda mais a concentração do mercado nas mãos de poucas editoras.

Dessa forma, há uma grande oferta de títulos diferentes disponíveis comprometendo-se a "levar ao domínio de uma língua estrangeira ou, no mínimo, até um determinado nível de acordo com o Quadro Comum Europeu para o Ensino de Línguas" (BOHUNOVSKY, 2009, p. 24).

A preocupação das editoras em padronizar os LD em certa medida aponta para uma tendência observada por Funk (2004) que trata sobre a semelhança aparente da maioria dos LD da atualidade que trazem consigo CDs, oferecem exercícios em sites e utilizam cores e temas semelhantes (cf. FUNK, 2004, p. 41). Ainda de acordo com esse autor, todos os LD atuais se referem de maneira explícita aos níveis estabelecidos pelo Conselho da Europa em suas capas.

Desse modo, nota-se que existe a tendência de buscar homogeneizar os LD como se o público que aprendesse alemão também fosse homogêneo, assim como aponta Bohunovsky (2009, p. 24). Nesse sentido, a fim de burlar o caráter homogeneizante do LD internacional e, também, o fato de não haver produção nacional intensa de LD implica necessariamente em uma série de adaptações desse LD internacional de acordo com o contexto em que ele é adotado.

Ainda que seja o material com o qual mais se tem contato durante as aulas de LE, o LD possui diversas funções dentro desse contexto. Nesse sentido, a próxima seção abordará as funções atribuídas ao LD de modo a mostrar quais as funções esse dispositivo tem no contexto do ensino de LE e, ainda, será apresentada uma discussão sobre outras funções atribuídas ao LD quanto à organização dos cursos. 


\subsubsection{Funções do livro didático}

Assim como foi discutido anteriormente, o LD é um dispositivo amplamente utilizado nas aulas de LE e figura muitas vezes como um dos únicos materiais que possibilitam ao aprendiz a oportunidade de ter contato com a cultura dos países nos quais se fala a língua estudada. A partir desse fato já se verifica a importância atribuída a este dispositivo para as aulas de LE. Contudo, a sua utilização acarreta na atribuição de diversas funções para o LD nos cursos.

Dessa maneira, esta seção aborda aspectos relacionados às funções atribuídas ao LD no contexto de ensino de LE levando em consideração diversos fatores que afetam diretamente esse contexto. Dito de outra maneira, esta seção busca debater sobre os papéis atribuídos normalmente ao LD quando se utiliza esse dispositivo nas aulas de LE.

O LD é o dispositivo com o qual o aluno tem mais contato e aquele com o qual ele vai se relacionar de forma mais intensa durante as aulas. Nesse sentido, assim como aponta Uphoff (2009), o LD fornece uma grande quantidade de textos e atividades que de certa forma permeiam a ação docente.

Neste ínterim, o LD traz uma pré-estruturação do trabalho docente a ser realizado dentro da sala de aula. Em outras palavras, de acordo com Neuner (1999), o LD apresenta uma estrutura que contempla praticamente todas as etapas do ensino e pode, portanto, ser considerado como a "materialização do planejamento de um curso de línguas" (UPHOFF, 2009, p. 61).

Ao discutir sobre as funções do LD no contexto da aula de LE, Neuner elabora uma lista na qual ficam claras as funções estabelecidas pelo autor para o LD:

- Operacionaliza o currículo,

- Determina os objetivos do curso,

- Define os conteúdos e sua hierarquização (progressão),

- Escolhe os procedimentos didáticos,

- Define as formas de organização social na aula (trabalho em dupla ou em grupo, aula expositiva, etc.),

- Regulamenta o uso das mídias (fitas, filmes, etc.) e 
- Determina os itens e a forma de avaliação ${ }^{14}$ (NEUNER, 1999, p. 160 apud UPHOFF, 2009, p. 61)

A partir dessa lista, Neuner deixa claro que o LD é um dispositivo que direciona o trabalho docente no sentido de operacionalizar o seu fazer pedagógico. Apesar dessa lista não deixar clara a relação que se estabelece entre o LD e o aprendiz que o utiliza durante as aulas, ao analisá-la, nota-se que o dispositivo está longe de ser apenas uma ferramenta com a qual tanto professores quanto aprendizes precisam lidar a fim de encontrar uma série de conteúdos organizados de forma sistemática. Quando se leva em consideração, sobretudo os quatro primeiros tópicos da lista, fica claro que o LD exerce um papel fundamental no processo de ensino-aprendizagem, tanto para o professor, quanto para os alunos. Essa importância crescente que se verifica acerca do dispositivo poderia explicar, inclusive, o fato de sua presença ser considerada muitas vezes como algo natural e inquestionável assim como aponta Souza (1995). Além disso, vale ressaltar que também cabe ao LD, por exemplo, organizar a macroestrutura dos cursos.

Ao afirmar que o LD operacionaliza o currículo e determina os objetivos do curso, exclui-se de certa forma as necessidades dos aprendizes na medida em que o LD atuando como currículo não necessariamente leva em consideração os alunos e sim o cumprimento da progressão disposta pelo dispositivo.

Também discutindo a acepção de LD e as fronteiras de seu uso, Maijala (2007) aponta que, entre outros fatores, o LD é uma das opções viáveis para a aula de LE devido à tradição do uso desse dispositivo, também fatores práticos como a inserção relativamente simples desse material em cursos e, ainda, o fato de que seu uso não depende necessariamente de fatores técnicos como energia elétrica (cf. MAIJALA, 2007, p. 543). O argumento de Maijala cabe perfeitamente para 0 contexto dos CEL já que, por um lado, reforça a ideia de que a presença do LD é inquestionável e, por outro, em algumas escolas públicas há notável carência de materiais audiovisuais, internet, rádios, lousas eletrônicas ou outros elementos de modo que o uso do LD se torna quase obrigatório, já que não necessita - a priori de nenhum desses elementos.

\footnotetext{
${ }^{14}$ Tradução do original em alemão de Uphoff (2009)
} 
No decorrer de sua argumentação, Maijala deixa claro que ao analisar um LD é preciso levar em consideração não apenas o professor, mas também o aluno já que ele se insere em um contexto que contém, além do professor e dos alunos, também as situações particulares de cada lugar que abriga um curso de LE:

O livro didático é parte integrante dentro de um conjunto maior de condicionantes, ele está por assim dizer "entre o programa de ensino (concepção pedagógica e metodológica), a situação de ensino (condições institucionais/ do professor) e os aprendizes, ou seja, o grupo "15" (MAIJALA, 2007, p. 544 citando NEUNER, 1994, p. 9, aspas no original)

Assim, o LD pode ser descrito como um dispositivo cercado por expectativas de diversas instâncias já que professores o utilizam para organizar o seu fazer pedagógico e os próprios alunos também esperam que o curso se organize a partir do próprio LD como aponta Deusa Maria de Souza (1995, p. 121):

O aluno espera (e, por razões econômicas, também os pais), ao comprar o
livro didático adotado pelo professor, que ele seja usado, passo a passo. Se
o professor resolve "pular" partes do livro, mudar a ordem de apresentação
do conteúdo, ou se ele se alonga numa unidade específica, fazendo uso de
materiais didáticos e/ou atividades suplementares, extralivro, o aluno sofre
uma espécie de estranhamento e tende a cobrar do professor a
"obediência" ao programa, e à sequência do livro didático (Aspas no
original).

Parece pertinente destacar que o artigo de Souza citado aqui, apesar de ter sido publicado há mais de 20 anos, ainda pode suscitar discussões relevantes acerca do papel e da importância que o LD possui ainda hoje. No artigo, a autora apresenta através de diversas vozes que muitas vezes a utilização do LD por completo é visto como sinônimo de qualidade pelos alunos e também pelos seus responsáveis. Nesse sentido, mais do que fatores econômicos que envolvem a utilização desse dispositivo em aula, o fato deste panorama não ter se alterado ainda demonstra a importância que o LD possui para o contexto de ensinoaprendizagem de LE de forma ampla já que, mesmo com o avanço tecnológico a sua presença ainda é vista como parâmetro para se definir a qualidade de um curso

\footnotetext{
${ }^{15}$ No original: „Das Lehrwerk ist Bestandteil innerhalb eines größeren Bedingungsgefüges, es steht sozusagen ,zwischen dem Lehrplan (Fachdidaktische und Fachmethodische Konzeption), der Lehrsituation (institutionelle Bedingungen/ Lehrer) und den Lernenden bzw. der Lerngruppe'“.
} 
e, de certo modo, a sua conclusão ainda é confundida com a aprendizagem eficaz de um idioma.

A partir dessa percepção, o LD pode ser descrito como um dos elementos de maior visibilidade na aula de LE já que, além de atuar no trabalho do professor, é um dispositivo que figura no imaginário dos alunos como um elemento importante para o seu processo de ensino aprendizagem uma vez que o sucesso do curso e o processo de aprendizagem aparecem atrelados ao dispositivo.

Dessa forma, levando em consideração que o LD é um dispositivo que se relaciona com professores e alunos, a próxima seção discutirá como esse material se enquadra no contexto de análise de necessidades descrito por Weissenberg.

\subsubsection{O livro didático e a análise de necessidades}

As discussões apresentadas nas seções anteriores atestam que o LD representa um importante dispositivo para a aula de LE chegando, até mesmo, a ser entendido como sinônimo de material didático e planejamento. Não obstante, estando clara a diferença entre material didático e LD e, levando em consideração as funções atribuídas a esse dispositivo, falta analisar como o LD se enquadra dentro da terminologia proposta por Weissenberg (2012) quando define os tipos existentes de necessidades.

Apesar de descritas separadamente, as necessidades da forma como são retratadas por Weissenberg possuem uma relação estreita entre si. Mesmo quando analisado apenas um dos tipos de necessidades, há sempre elementos que remetem aos outros tipos. Nesse sentido, mesmo analisando o LD com enfoque nas necessidades subjetivas e processuais, não se pode excluir as necessidades objetivas. Dito de outra forma, ao tratar sobre necessidades é preciso ter em mente que quase sempre haverá elementos que remetem a mais de um tipo de necessidade. 
Ao analisar, por exemplo, a relação entre LD e aprendiz ou a forma como o LD é visto pelos alunos, estamos tratando do que Weissenberg chama de necessidades subjetivas, uma vez que o foco está nos alunos em relação ao seu processo de aprendizagem. Contudo, é necessário ter em vista que a escolha do livro didático, bem como outros fatores que envolvem a preparação das aulas, carga horária e organização do curso, dependem em grande medida da análise das necessidades descritas por Weissenberg como necessidades objetivas.

Como se trata de um material da aula, o LD também poderia ser analisado a partir do viés apresentado pelas necessidades processuais de acordo com Weissenberg, que tratam justamente sobre materiais e espaço físico que abriga o curso de LE, bem como as consequências disso para o processo de aprendizagem dos alunos. Neste caso, quem percebe esses elementos poderia ser o professor que utiliza esse LD.

A própria escolha e utilização do LD nesse contexto não dependem exclusivamente do professor, mas sim, de instâncias superiores de modo que também existe, portanto, ligação entre o LD e as necessidades objetivas. Além disso, os conteúdos programáticos são escolhidos pelo professor em conjunto com a coordenação pedagógica tendo em vista exclusivamente a estrutura apresentada pelo LD, de modo que a organização do curso é feita para coincidir com a quantidade de unidades que esse LD possui.

Nesse sentido, o LD, em geral, no contexto do ensino de LE é permeado por todos os três tipos de necessidades descritos por Weissenberg (2012). Além disso, o fato de até o momento não existir um currículo validado pela Secretaria de Educação do Estado de São Paulo que permeie o ensino de alemão nos CEL, torna o dispositivo o instrumento que tem o papel de currículo (a seção 2.1.4. apresenta uma discussão sobre currículo e o ensino de alemão no CEL). Cabe ressaltar que, de acordo com informações obtidas junto ao coordenador de projetos do Centro de Cooperação Pedagógica do Instituto Goethe de São Paulo, existe um currículo de alemão para os CEL que ainda não foi publicado. Ainda de acordo com o coordenador, não há previsão para que esse documento seja publicado.

Dessa forma, nota-se que os três tipos de necessidades descritas por Weissenberg estão presentes ao quando se aborda a presença do LD nas aulas de 
LE. A sua escolha e a atuação do dispositivo como currículo fazem parte das necessidades objetivas, o modo como os alunos se colocam frente a esse LD e as suas expectativas são pertencentes às necessidades subjetivas e, por fim, aspectos percebidos pelo professor em relação ao uso do LD pelos alunos como as suas dificuldades, por exemplo, se enquadram nas necessidades processuais. 


\section{Metodologia}

Este capítulo trata acerca dos princípios metodológicos que nortearam o levantamento de dados empíricos para esta pesquisa. Tal levantamento consistiu na aplicação de atividades didáticas de reflexão sobre o LD em forma de estações e de dois questionários. Cabe ressaltar que antes da coleta empírica foi feita uma pilotagem com outra turma que não seria a analisada a fim de verificar qual seria a reação dos alunos ao responder um questionário que tratasse acerca do LD. A partir dessa pilotagem, que será descrita em uma seção específica, surgiu a necessidade de elaborar primeiramente as estações ${ }^{16}$ antes de pedir para que os alunos respondessem aos questionários.

Quanto à estrutura, o capítulo está dividido em cinco grandes blocos. Primeiramente, serão apresentados aspectos teóricos sobre estudos de caso levando em conta que este estudo possui características que possibilitam enquadrálo dessa forma. Entre estes aspectos estão, por exemplo, a investigação de um contexto específico, a tentativa de compreender um fenômeno a partir da perspectiva dos participantes da pesquisa e, ainda, testar uma hipótese inicial. A esta apresentação, segue uma seção que trata sobre a análise de necessidades por meio do processo de triangulação de dados. Finalmente, os três últimos blocos do capítulo tratam acerca da coleta de dados de forma específica trazendo justificativas e relatos sobre as fontes de dados utilizadas.

\subsection{Da natureza do trabalho e o contexto da pesquisa: aspectos gerais}

O estudo de caso é um procedimento metodológico muito útil quando se busca entender algum aspecto específico que envolva um determinado contexto. Desse modo, nesta seção abordarei primeiramente aspectos teóricos gerais

\footnotetext{
${ }^{16}$ Diferentes tarefas oferecidas e organizadas na sala de aula de maneira rotativa com os devidos materiais a fim de que o aluno realize diversas atividades ao fim de determinado período de tempo. Essa estrutura será explicada na seção 3.4 deste trabalho.
} 
inerentes a esse tipo de estudo para depois apresentar o contexto concreto em que ocorre a pesquisa.

\subsubsection{Definição do termo "estudo de caso" e o caráter da pesquisa}

O estudo de caso é uma das configurações possíveis de uma pesquisa. Em geral, utiliza-se essa configuração quando se deseja analisar ou descrever aspectos únicos ou particulares de algum contexto. Ao tratar sobre "caso", de acordo com Flick (2009), é possível abordar pessoas, uma família, uma comunidade ou, ainda, uma instituição (cf. FLICK, 2009, p. 177), assim como ocorre nesta pesquisa, que tem como foco o caso específico de uma unidade do CEL.

Obviamente existem limites quanto à validade de um estudo realizado nesses moldes. Entre eles, vale ressaltar a dificuldade de se generalizar os resultados de uma investigação desse tipo, a qual, de acordo com Flick (2009, p. 178) configura mais um problema "no sentido teórico do que no sentido estatístico" ${ }^{17}$, que pode ser compensado pela realização de uma série de estudos de caso correlatos.

Apesar disso, um estudo de caso pode contribuir em grande medida para que se entenda melhor algum aspecto que cerca um contexto que não é amplamente conhecido, assim como ocorre no caso do CEL. Nesse sentido, pode-se considerar que o estudo de caso almejado apresenta uma função exploratória (GONSALVES, 2007, p. 66), uma vez que ajuda a gerar conhecimentos acerca de um objeto de pesquisa ainda pouco investigado.

\subsubsection{Contexto concreto da pesquisa}

A pesquisa, bem como a coleta de dados foram realizadas no âmbito de uma unidade do CEL que se localiza em um município da grande São Paulo. Nessa unidade são oferecidos, além do curso de alemão, também o curso de inglês e de espanhol. A escola que aloca o CEL neste município da grande São Paulo é muito

\footnotetext{
${ }^{17}$ No original: [Bei der Konzentration auf einen Fall ergeben sich häufig Probleme der Verallgemeine-rung] weniger im statistischen als im theoretischen Sinn.
} 
conhecida na região e, além do CEL, oferece aulas no ensino regular para alunos do ensino médio na modalidade integral, na qual os alunos iniciam suas aulas às sete da manhã e são dispensados às quatro e meia da tarde.

Assim como ocorre em outras unidades do CEL, o número de turmas e de alunos de espanhol se sobrepõe aos outros idiomas oferecidos pela unidade. Dados do início do primeiro semestre de 2017 - semestre em que a coleta de dados ocorreu - fornecidos pela coordenação pedagógica da unidade apontam para um total de 464 alunos distribuídos em 20 turmas.

De forma específica e dividindo esses números nos três idiomas oferecidos na unidade, havia:

- 73 alunos de alemão divididos em quatro turmas;

- 87 alunos de inglês divididos em três turmas - todas do mesmo nível ${ }^{18}$;

- 304 alunos de espanhol divididos em 13 turmas de todos os níveis e estágios.

No início de 2017, devido a questões de legislação e, ainda, levando em consideração o fato de que houve em uma das turmas de alemão uma taxa elevada de evasão, houve a necessidade de criar uma turma de alemão multisseriada. De acordo com a terminologia utilizada para descrever as turmas nos CEL, juntaram-se duas turmas: a turma $B$ que estava iniciando o nível dois do segundo estágio e a turma $\mathrm{C}$ que estava iniciando o nível um do segundo estágio.

A turma mais antiga (turma A) iniciou o curso no segundo semestre de 2014, logo após a implantação do CEL, e no final do primeiro semestre de 2017 finalizou os três anos de curso previstos pela legislação que rege o funcionamento dos CEL tornando-se, portanto, a primeira turma a finalizar o curso de alemão nesta unidade do CEL. Outra das turmas (turma B) iniciou seus estudos no início de 2015 e se enquadrava no período da coleta de dados no segundo estágio do segundo nível. Por fim, a última turma (turma $\mathrm{C}$ ) iniciou seus estudos no início do segundo semestre de 2015 e se enquadrava no primeiro estágio do segundo nível na época da coleta.

\footnotetext{
${ }^{18}$ Os cursos de inglês nos CEL têm duração total de um ano, diferente dos demais idiomas oferecidos. Ademais, as inscrições para o curso de inglês são feitas apenas anualmente e não semestralmente.
} 
Ainda no início de 2017, uma nova turma de alemão (turma D) iniciou seus estudos na unidade do CEL investigada, no entanto, esta não foi utilizada para a coleta de dados devido ao fato da pesquisa já estar em andamento quando do início de seus estudos. Além disso, como é uma turma nova, o contexto é um pouco diferente do que se verificava nas demais turmas, uma vez que esta turma já iniciou seus estudos utilizando o livro Deutsch.com da editora Hueber a fim de seguir uma tendência dos demais CEL que oferecem a língua alemã, as demais turmas ainda utilizavam o livro Planet, também da editora Hueber. A escolha das turmas para o levantamento de dados foi feita considerando o nível e o estágio em que elas se encontravam. Desse modo, a turma mais antiga foi a escolhida para a pilotagem do questionário que foi elaborado e aplicado para as demais turmas que se juntaram.

Em relação aos alunos, na turma mais antiga $(A)$, a maioria dos alunos já havia concluído o ensino médio e continuava frequentando as aulas de alemão no CEL por estarem assegurados por lei de que o curso deveria ser concluído uma vez que iniciado enquanto o aluno estivesse devidamente matriculado no ensino médio. Nas demais turmas, cerca de $90 \%$ dos alunos ainda cursa o ensino médio.

Nesse sentido, como o número disponível de LD é bem diferente para a turma iniciante e para a turma investigada e levando em consideração a possível falta de experiência dos alunos iniciantes com o LD de alemão e com a própria língua alemã, foi definido que esta turma não faria parte da coleta de dados.

\subsubsection{Atuando como professor e pesquisador}

Um aspecto inerente ao contexto, e que não pode ser deixado de lado, consiste no fato do professor e pesquisador estarem centrados na mesma figura de modo que, para os alunos, às vezes era difícil ter a percepção de que não seriam julgados ou avaliados.

Nesse sentido, antes do início das atividades nas estações, foi perceptível que os alunos ficaram um pouco preocupados quanto ao que ocorreria naquele momento. Tal reação deve-se também ao fato de que a coleta foi realizada dentro do horário da aula, de modo que, mesmo tendo sido avisados previamente com uma 
semana de antecedência acerca do que ocorreria na aula, eles pareceram ansiosos e um tanto quanto receosos quanto ao que ocorreria, sobretudo, no primeiro dia da coleta de dados.

Tendo em vista tal reação dos alunos, antes do início da atividade nas estações, senti a necessidade de explicar mais uma vez os objetivos daquelas atividades e, ainda, precisei deixar claro que todos os dados obtidos ali seriam utilizados em sigilo sem que seus nomes fossem divulgados. Além dessa explicação, os alunos receberam e assinaram um termo de consentimento para a utilização dos dados na pesquisa que continha a informação do anonimato utilizado para a pesquisa. O termo se encontra nos anexos deste trabalho.

Contudo, ao iniciar a coleta, os alunos se mostraram receosos quanto às atividades e ainda perguntaram muito sobre respostas certas e erradas. Dito de outra maneira: ficou claro que os alunos tiveram receio de fornecer respostas que acarretassem em uma avaliação negativa do professor.

Dessa forma, em todas as coletas de dados houve a preocupação em explicar que tudo se tratava de uma pesquisa e que aquelas respostas não seriam avaliadas para compor os resultados do bimestre.

Com isso, no último dia de coleta, os alunos já se mostraram um pouco mais acostumados com aquela dinâmica na qual a figura do professor não estava agindo como tal, mas sim como pesquisador. Vale ressaltar, contudo, que a presença do professor-pesquisador durante as coletas influenciou as respostas dos alunos em alguns momentos, sobretudo, quando se observou uma divergência clara entre perguntas em forma de escala e de resposta livre do questionário. Por um lado, os alunos escolhiam valores altos nas escalas, porém, por outro lado, ao explicar a sua opinião, notou-se que o valor escolhido na escala não condizia com a opinião manifestada pelo aluno na pergunta de resposta livre. Essas inconsistências nos discursos serão analisadas com maiores detalhes na seção 5.3.1, que trata sobre a tarefa de refletir sobre o LD na presença do professor-pesquisador. 


\title{
3.2. Análise de necessidades por meio da triangulação de dados
}

Tendo em vista que este trabalho se baseia em uma análise qualitativa de dados obtidos a partir de diversas fontes, torna-se necessário esclarecer metodologicamente em que consiste essa triangulação de dados e quais os seus efeitos para a pesquisa. Cabe ressaltar que Richards (2001), ao tratar sobre os procedimentos de uma análise de necessidades, cita o trabalho através de triangulação:

\begin{abstract}
Uma variedade de procedimentos pode ser usada ao se conduzir uma análise de necessidades e o tipo de informação obtida é, em geral, dependente do tipo de procedimento selecionado. Como apenas uma fonte de informação é provavelmente incompleta ou parcial, uma abordagem triangular (isto é, coletar informação de duas ou mais fontes) é aconselhável $(\text { p. } 59)^{19}$
\end{abstract}

Desse modo, nota-se uma relação direta entre este princípio e a análise de necessidades proposta para esta pesquisa.

Assim como aponta Karin Aguado (2015), o termo triangulação foi emprestado da trigonometria para determinar um procedimento a partir do qual se combina uma série de dados de forma sistemática.

O termo apenas passou a ser utilizado como conceito metodológico a partir dos anos 50 do século passado, porém, ainda de acordo com Aguado (2015), já nos anos 30 e 40 havia estudiosos das áreas de ciências sociais e antropologia, por exemplo, que se utilizavam desse recurso sem nomeá-lo. A partir do momento em que se torna explicito, muito se tem discutido acerca de seus benefícios e usos até os anos 70, quando Denzin (1970, apud AGUADO 2015, p. 48), dentro das discussões acerca do termo, diferencia a triangulação de dados em quatro tipos:

1. Triangulação de dados: envolve a análise de várias fontes de dados que, por sua vez, são obtidos em momentos e contextos diferentes;

2. Triangulação de investigadores: envolve a análise sistemática de dados obtidos de diversos investigadores;

\footnotetext{
${ }^{19}$ No original: "A variety of procedures can be used in conducting needs analysis and the kind of information obtained is often dependent on the type of procedure selected. Since any one source of information is likely to be incomplete or partial, a triangular approach (i.e., collecting information from two or more sources) is advisable".
} 
3. Triangulação teórica: envolve a utilização de diversas teorias para tratar acerca de dados obtidos;

4. Triangulação metodológica: consiste na combinação crítica e sistemática de diversos métodos de análise de dados convergindo em apenas uma análise.

Quanto às funções do procedimento de triangulação de dados, Aguado cita duas principais, sendo a primeira referente à validação de dados ou resultados já existentes e, a segunda, referente à expansão ou à complementação de possíveis resultados (cf. AGUADO 2015). Quando se trata da primeira forma, espera-se que os dados, ao final da triangulação, estejam convergindo para validar o estudo. No entanto, a autora segue em sua argumentação de modo a mostrar que, muitas vezes, a não convergência dos dados também pode ser um fator decisivo para o estudo, sobretudo, quando se trata de pesquisas qualitativas.

A forma como essa pesquisa foi conduzida possibilitou o uso da triangulação para o desenvolvimento de ferramentas de coleta de dados. Nesse sentido, os dados obtidos já na primeira etapa da coleta foram utilizados para o desenvolvimento das atividades e dos questionários utilizados nas demais coletas.

Primeiramente, houve uma pilotagem de um questionário que demonstrou a necessidade de se inverter a ordem em que as ferramentas de coleta seriam utilizadas. A ideia inicial era propor, primeiramente, um questionário para, a partir disso, desenvolver atividades didáticas. Não obstante, essa pilotagem - que será abordada na seção 3.3.1 - mostrou um possível despreparo dos alunos no que concerne ao fornecimento de respostas sem que houvesse algum tipo de preparação. Desse modo, optou-se por desenvolver as atividades em forma de estações para que, quando estivessem em frente ao questionário, as suas respostas fossem mais refletidas. Os dados obtidos nas estações da primeira coleta de dados foram utilizados como base para o desenvolvimento do questionário e das demais atividades utilizadas nas coletas posteriores.

A partir do contexto exposto e, ainda, levando em consideração o fato de que nessa pesquisa foram utilizadas diversas fontes de dados e que estes, por sua vez, foram obtidos em períodos diferentes, é possível dizer que a utilização do processo de triangulação de dados tem relação com o que Aguado chama de validação (cf. AGUADO, 2015, p. 51). 
Nesse sentido, busca-se a validação dos dados apresentados a partir do momento em que os dados obtidos a partir de uma coleta eram observados e utilizados como base para a produção de outras atividades que seriam aplicadas posteriormente.

Além disso, os dados obtidos com uma ferramenta de coleta serão analisados de maneira a construir explicações plausíveis para os questionamentos levantados pelas outras ferramentas utilizadas. Assim, além da validação dos dados, a triangulação de dados funcionará como complementação (cf. AGUADO, 2015, p. 52).

\subsection{Coleta de dados: descrição geral}

Os dados coletados para esta pesquisa foram obtidos em três etapas e utilizando duas fontes principais: um questionário e atividades didáticas aplicadas aos alunos. Tanto o questionário, quanto as atividades didáticas foram aplicadas para os alunos durante as aulas de alemão. Contudo, antes da coleta efetiva dos dados, foi desenvolvida e aplicada uma pilotagem do questionário a fim de verificar como os alunos se comportariam no momento de responder a um questionário. Dessa forma, antes de tratar sobre as etapas da coleta, apresentarei na próxima seção o desenvolvimento da pilotagem.

\subsubsection{Desenvolvimento e aplicação da pilotagem}

A pilotagem do questionário foi realizada no final de $2016 \mathrm{com}$ uma turma que encerraria o curso de alemão no final do primeiro semestre de 2017 e tinha como objetivo avaliar como os alunos encarariam o fato de ter que responder a um questionário acerca do LD utilizado durante as aulas.

Dessa forma, foram elaboradas cinco perguntas que tinham como objetivo verificar de forma prévia como seriam as respostas fornecidas pelos alunos e se eles 
seriam capazes de responder questões que diziam respeito ao LD de maneira consistente.

Além das informações iniciais, que pediam para que os alunos fornecessem seu nome, idade, o início de seus estudos de alemão e o nome do LD utilizado, os enunciados desenvolvidos foram os seguintes:

1. Acredito que o livro didático (não) é importante na aula de alemão porque:

2. Na minha opinião, a aula seria melhor sem a presença do livro didático: Sim

Não

Procure explicar a sua opinião:

3. Tenho um exemplar do livro didático em casa:

$\operatorname{Sim}$

Não

4. (Não) Comprei o livro didático porque:

5. Para estudar em casa uso:

Quadro 1: Perguntas aplicadas como pilotagem de um questionário

O intuito de colocar o "não" entre parênteses no enunciado 1 e no enunciado 4 era deixar claro para os alunos que eles poderiam fornecer uma resposta positiva ou negativa. Nesse sentido, apesar de não haver nenhuma instrução escrita sobre isso, eles foram avisados sobre essa possibilidade no momento em que receberam a atividade.

Essas perguntas foram entregues aos alunos em uma folha na qual havia uma breve explicação sobre a pesquisa para que eles soubessem do que se tratava. Contudo, como essas perguntas seriam respondidas no final do período de aulas da turma - que estudava aos sábados - foi necessário fornecer uma explicação e 
deixar claro que as perguntas faziam parte de um projeto de pesquisa e que não contabilizariam notas para a turma.

No dia em que essa pilotagem foi aplicada, dez alunos estavam presentes e responderam às perguntas. Em geral, os alunos responderam rapidamente as perguntas e surgiu a impressão de que eles não se interessaram em opinar sobre 0 LD que era utilizado durante as aulas. Posteriormente, essa hipótese inicial se mostrou verdadeira já que algumas respostas foram muito curtas, vagas e consistiam, muitas vezes, de uma palavra ou uma pequena frase que não revelava necessariamente a visão do aluno acerca do aspecto perguntado na questão. Algumas respostas obtidas com a segunda pergunta da pilotagem ("na minha opinião, a aula seria melhor sem a presença do livro didático") servem de exemplo:

(Não) Pois ajuda no aprendizado. (Respondente P1)

(Não) Sem o livro o professor teria mais dificuldade para ensinar. (Respondente P2)

(Não) Pois acredito que é bom ter um material para estudar mas não gosto da ideia de alienação. (Respondente P3)

(Sim) A aula ficaria mais dinâmica, não ficaríamos presos apenas nas atividades do livro. (Respondente P4)

A resposta fornecida pelo respondente $\mathrm{P} 3$, que cita o termo "alienação", já apresentava um indício de que as respostas de alguns alunos seriam muito vagas. Neste caso, por exemplo, não fica claro o que o aluno quer dizer com o uso dessa palavra já que ele, por um lado, afirma que a aula não ficaria melhor sem a presença do LD, mas que, por outro lado, parece que ele faz alguma crítica ao uso do dispositivo em aula.

Com isso, a pilotagem mostrou a necessidade de fazer com que os alunos se preparassem previamente e que refletissem acerca do LD antes de fornecer as suas respostas para o questionário. Desse modo, foi feita a opção em desenvolver a coleta de dados por meio de atividades didáticas oferecidas através de estações que, por sua vez, serviriam de suporte para preparar os alunos para responder aos questionários. 
As etapas da coleta, bem como a preparação necessária para cada uma dessas etapas será descrita na próxima seção.

\subsubsection{Etapas da coleta de dados}

Conforme discutido na seção anterior, durante as coletas, as atividades didáticas foram aplicadas em forma de trabalho em estações a fim de servir como preparação para que os alunos pudessem responder ao questionário, que foi aplicado em dias diferentes em duas etapas.

A tabela abaixo apresenta as três coletas realizadas, bem como a quantidade de participantes presentes em cada uma das coletas:

\begin{tabular}{|c|c|}
\hline Etapa/ Data & Atividades desenvolvidas \\
\hline $\begin{array}{l}\text { Etapa } 1 \text { - } 29 \text { de março } \\
\text { de } 2017 \\
\text { (8 participantes) }\end{array}$ & $\begin{array}{l}\text { - Quatro estações: } \\
\text { Estação 1: Aufbau des Kursbuchs } \\
\text { Estação2: Tipps und Strategien im Kursbuch } \\
\text { Estação 3: Aktivitäten im Arbeitsbuch } \\
\text { Estação 4:Lernkontrolle und Selbstevaluation } \\
\text { - Atividade "Para refletir" }\end{array}$ \\
\hline $\begin{array}{l}\text { Etapa } 2 \text { - } 10 \text { de maio } \\
\text { de } 2017 \\
\text { (7 participantes) }\end{array}$ & $\begin{array}{l}\text { - Três estações: } \\
\text { Estação 1: EINSTIEGSSEITEN und DAS } \\
\text { KANN ICH SCHON } \\
\text { Estação 2: Übungen im Arbeitsbuch } \\
\text { Estação 3: Wörterbücher } \\
\text { - Primeira etapa do questionário }\end{array}$ \\
\hline $\begin{array}{l}\text { Etapa } 3-7 \text { de junho } \\
\text { de } 2017 \\
\text { ( } 6 \text { participantes) }\end{array}$ & $\begin{array}{l}\text { - Três duplas trabalham com o tema } \\
\text { "Sprachbiographie" } \\
\text { - Segunda etapa do questionário }\end{array}$ \\
\hline
\end{tabular}

Tabela 1: etapas da coleta de dados

Na primeira coleta, além do trabalho em estações, os alunos fizeram uma atividade de reflexão que serviu de apoio para a elaboração do questionário assim como será descrito posteriormente. Nesse sentido, o questionário, dividido em duas 
partes, foi aplicado nas demais aulas em que a coleta foi feita, na etapa 2 e na etapa 3 , respectivamente.

Nas próximas seções apresentarei os aspectos pertinentes à coleta de dados. Primeiramente abordarei cada uma das atividades didáticas aplicadas aos alunos e descreverei desde a sua elaboração, até a sua aplicação. Em seguida, discutirei de forma específica o processo de elaboração do questionário bem como as razões que levaram à escolha dessa ferramenta metodológica. Também explicarei as razões e critérios utilizados para a divisão do questionário em duas partes.

\subsection{Atividades didáticas: desenvolvimento e aplicação}

Nesta seção, com o intuito de tratar sobre as atividades didáticas que foram utilizadas, abordarei, primeiramente, sobre os princípios da aula livre (Freiarbeit) que nortearam o desenvolvimento dessas atividades aplicadas em forma de estações. A essa apresentação, segue um relato sobre essas atividades, sua aplicação e seu conteúdo.

\subsubsection{Justificativa do uso da Freiarbeit}

Uma das preocupações existentes quando da decisão de se coletar dados em uma turma específica de uma unidade do CEL era justamente o fato de que a pilotagem havia apontado para o fato que os alunos não responderiam ao questionário sem uma reflexão prévia. Devido a isso, foi necessário encontrar uma forma de fazer com que esses alunos começassem a refletir acerca dos diversos elementos que cercam a aula de LE, entre eles, o próprio LD. Nesse sentido, 0 trabalho feito a partir de atividades oferecidas em forma de estações foi a solução encontrada para promover tal reflexão acerca do LD antes que os alunos respondessem os questionários. 
Tendo encontrado o trabalho com estações como alternativa viável, a preparação das estações e das aulas seguiu em grande medida as orientações didático-metodológicas de uma Freiarbeit.

Esse formato de aula está em consonância com a abordagem orientada para a ação e postulados construtivistas de acordo com Gudjons (2008) que, além de descrever os passos de uma Freiarbeit, também afirma que uma das configurações possíveis desse tipo de trabalho é a Stationenlernen:

Um caminho para a aula livre [Freiarbeit] é o aprendizado em forma de estações, nas quais diferentes tarefas (eletivas e obrigatórias) com os devidos materiais são organizadas na sala de aula em estações. (GUDJONS, 2008 p. 27)

Além disso, tal formato no qual estações de estudo são oferecidas ao aluno, leva o aprendiz a desenvolver autonomia em seus estudos uma vez que este se torna "sujeito de seu próprio processo de aprendizagem" (CHECCETTO, 2002 p.237). Desse modo, a aposta em oferecer esse tipo de atividade aos alunos era que eles, tendo refletido e produzido conhecimentos acerca do LD, estivessem mais aptos a fornecer respostas refletidas quando estivessem em frente ao questionário.

De acordo com Checceto, outros objetivos e vantagens da Freiarbeit são:

- Conduzir o aluno a uma certa autonomia em relação à própria aprendizagem;

- Desenvolver nele o senso de responsabilidade;

- Levá-lo a exercitar a sua criatividade;

- Estimular a interação com o outro (Gemeinschaftsgefühl "sentimento de pertencer ao coletivo, ser parte dele");

- Propiciar situações em que o aluno se testa, superando e/ou reconhecendo suas limitações na busca de soluções para as dificuldades encontradas;

- Estimular a curiosidade, despertando-o para novos interesses. (CHECCETTO, 2002 p.237)

Durante o desenvolvimento de uma Freiarbeit, o papel do professor é o de observar o andamento das estações de forma a conhecer seus alunos, suas dificuldades e seus acertos. Além disso, vale ressaltar que cabe ao professor escolher os temas que serão abordados em cada uma das estações que serão disponibilizadas para os alunos, bem como as atividades que farão parte de cada

\footnotetext{
${ }^{20}$ No original: "Ein Weg zur Freiarbeit ist auch Stationenlernen, bei dem unterschiedliche Aufgaben (Wahl- und Pflicht-) Stationen mit entsprechenden Materialien im Klassenraum zugeordnet sind".
} 
uma das estações tendo em vista diferentes graus de dificuldade entre as atividades oferecidas.

Uma vez que esteja realizando as atividades de determinada estação, o aluno é livre para dividir o trabalho entre os colegas que compõem o grupo ou, ainda, para iniciar o trabalho por qualquer uma das atividades da estação. Apesar de estar livre para organizar o seu trabalho em cada estação, é preciso que o aluno controle os resultados obtidos a partir de materiais fornecidos pelo próprio professor. Caso tenha dúvidas, o aluno deve ser capaz de consultar os materiais que estão presentes na estação, consultar os colegas e apenas em último caso consultar o professor de acordo com regras que devem ser estabelecidas previamente.

Quanto ao número de participantes de uma Freiarbeit, Checceto admite que com menos alunos o trabalho se torna mais simples (cf. CHECCETTO, 2002 p. 240), no entanto, ainda de acordo com a autora, uma quantidade grande de participantes não seria o impedimento para a realização de uma aula nesses moldes.

Outro ponto importante acerca desse tipo de aula é que ao final deve haver uma reflexão sobre o trabalho feito para que assim possam até mesmo surgir ideias de temas que podem ser utilizados para a realização de outra Freiarbeit. Nesse sentido, assim como se observa no quadro sinóptico da seção 3.3.2., ao final do primeiro dia em que a coleta de dados foi realizada com o trabalho em estações, foi entregue aos alunos uma última atividade intitulada como "para refletir". Essa atividade serviu justamente para ser uma reflexão acerca do que havia acontecido nas estações e também foi utilizada como base para o desenvolvimento das estações aplicadas nas demais coletas de dados.

Apesar de ser um procedimento didático-metodológico útil para diversos fins, há também algumas desvantagens em relação ao seu uso, de acordo com Checceto:

- Principalmente o início do trabalho tende a ser bastante desgastante na medida em que todos podem ficar agitados ou sentirem-se inseguros;

- Há um grande trabalho prévio do professor, o que exige tempo e pesquisa;

- A constatação de resultados também demanda tempo e requer capacidade analítica, o que exige exercício constante;

- Podem surgir contestações por parte de pais e mesmo de colegas e direção escolar. (2002, p. 242) 
O primeiro item da lista de Checceto, que trata sobre o início do trabalho, foi perceptível, sobretudo, no primeiro dia da coleta de dados. Os alunos, mesmo tendo sido avisados acerca do que aconteceria naquele dia e, mesmo já tendo trabalho em forma de estações anteriormente durante as aulas, se mostraram agitados com aquela configuração e com 0 fato de que as informações fornecidas seriam utilizadas para uma pesquisa. Dessa forma, mesmo após uma conversa com eles na qual as regras foram estabelecidas houve muitas perguntas que refletiam a insegurança dos alunos no momento em que o trabalho foi iniciado.

Tendo os preceitos da Freiarbeit em vista, a seguir abordarei os aspectos inerentes ao desenvolvimento das estações aplicadas e suas respectivas atividades.

\subsubsection{Elaboração das estações}

Assim como já foi apontado, em todas as três coletas de dados o trabalho em estações foi utilizado como um meio para estimular a curiosidade dos alunos acerca das diferentes funções e usos do LD na aula de alemão. Com isso, esperava-se que os aprendizes fossem levados à reflexão acerca de itens nem sempre discutidos, mas que por outro lado estão presentes em grande parte dos LD disponíveis no mercado atualmente como a divisão em módulos temáticos, o uso de diferentes cores para esses módulos, seções de revisão ao final das unidades e, ainda, páginas iniciais introdutórias para cada módulo ou capítulo.

Partindo, portanto, do princípio que os alunos deveriam refletir sobre o LD, nas duas primeiras coletas houve a tentativa de buscar entender quais eram os elementos presentes no LD que poderiam suscitar a curiosidade desses aprendizes.

\section{Primeira coleta de dados}

A primeira coleta, realizada em 29 de março de 2017, possuía quatro estações que tinham como objetivo principal fazer com que os alunos refletissem sobre a estrutura do Kursbuch e do Arbeitsbuch do livro Planet A2, que era o LD utilizado pela turma. Pensando na estrutura desses $L D$, as estações e as questões elaboradas para cada estação foram: 
- Estação 1: Aufbau des Kursbuchs

1. Observem o índice do Kursbuch da lição 17 até a 20 e tentem entender como o livro foi desenvolvido. Respondam as questões abaixo:

a. Como cada uma das lições se organiza? Existe alguma ordem?

b. A qual lição pertencem as páginas 29 a 32 ("Zum Schluss")?

c. Para que vocês acham que serve a página 5 ?

2. Na página 5 se encontram os objetivos de aprendizagem da lição 17 a 20. Comparem essa página com o índice, analisem os objetivos descritos nessa página e reflitam: todos os objetivos coincidem com o que está no índice? Falta alguma coisa? - Escrevam suas conclusões na folha branca.

3. Caso vocês ainda tenham tempo: comparem os módulos do índice e reflitam: todos eles são construídos de maneira parecida? Por que isso acontece? Vocês acham que os capítulos têm relação com o tema dos módulos? - Utilizem a folha verde para escrever suas conclusões.

Quadro 2: Enunciados da primeira estação

- Estação 2: Tipps und Strategien im Kursbuch

\section{Material impresso ${ }^{21}$ :}

Lektion 17:

Strategie, p. 7: "Bildinformationen helfen dir, die gehörten Informationen zu verstehen."

Tipp, p. 9: "Lern Verben immer mit der Perfektform."

Lektion 18:

Strategie, p. 12: "Lies vor dem Hören die Angaben. Das erleichtert das Verstehen von Einzelinformationen."

Tipp, p. 14: "Finde die Grammatikregel selbst. Lern Ausnahmen auswendig."

\section{Instruções:}

1. Em quase toda lição do Kursbuch do livro "Planet" há informações como "Strategien" e "Tipps". Observem essas informações das lições 17 e 18 e traduzam-nas para o português. Depois disso vocês podem comparar a sua tradução com a que está dentro do envelope na mesa.

2. As "Tipps" e "Strategien" precisam ajudar o aluno a aprender o conteúdo das lições. Formulem outro "Tipp" e outra "Strategie". Usem para isso a folha amarela.

3. Caso vocês ainda tenham tempo: discutam qual poderia ser a principal diferença entre "Tipp" e "Strategie". Escrevam as conclusões na folha verde.

\footnotetext{
${ }^{21}$ Todas as páginas do LD utilizadas como material impresso para as estações estão disponíveis nos anexos deste trabalho
} 
- Estação 3: Aktivitäten im Arbeitsbuch
Material impresso:
p. 9, Nr. 8 "Ergänze"
p. 11, Nr 5 "Schreib Sätze"
p. 17, Nr 7 "Logical"
p. 27, $\mathrm{Nr} 27$ "Wortliste Lektion 17 und 18"

\section{Instruções:}

1. Observem os quatro exercícios impressos do Arbeitsbuch do livro Planet 2 e discutam: o precisa ser feito aqui? Escrevam uma instrução em português para cada uma das atividades e comparem com o modelo no envelope que está na mesa.

2. Discutam em grupo o que se aprende em cada uma das quatro atividades. Anotem suas conclusões na folha azul.

3. Caso vocês tenham tempo: discutam - de quais atividades vocês gostam mais? E de quais vocês não gostam e por quê? Procurem explicar a sua opinião. Utilizem a folha verde.

- Estação 4: Lernkontrolle und Selbstevaluation

\section{Material impresso:}

Kursbuch, página 15: "Das kann ich schon"

Kursbuch, p. 28: "Das kann ich schon"

Arbeitsbuch, p. 24: "Das hast du gelernt"

Arbeitsbuch, p. 25: "Grammatik"

\section{Instruções:}

1. Observem as páginas impressas do Kursbuch e do Arbeitsbuch e tentem fazer os exercícios do Arbeitsbuch. Vocês encontrarão as respostas no envelope que está na mesa.

2. Reflitam sobre quais exercícios foram mais fáceis para vocês e quais foram mais difíceis. Pensem também sobre os possíveis motivos disso e escrevam suas conclusões na folha rosa.

3. Caso vocês ainda tenham tempo: discutam como se poderia estudar em casa com as páginas "Das kann ich schon" do Kursbuch e as páginas "Das hast Du gelernt" e "Grammatik" do Arbeitsbuch. Escrevam as conclusões na folha verde.

Quadro 5: Enunciados da quarta estação

Assim como se observa, em cada uma das estações - e isso vale também para as demais coletas - os alunos tinham três atividades, além dos materiais 
necessários para o desenvolvimento dessas atividades e as ferramentas para que 0 autocontrole pertinente a esse tipo de trabalho fosse feito.

A primeira questão foi pensada para ser sempre mais prática e para gerar uma primeira discussão em grupo acerca de algum aspecto específico do LD, a segunda questão tratava-se de algo que demandava algum tipo de produção dos alunos - escrita ou criativa - e, por fim, a terceira questão foi elaborada para que os alunos fizessem, caso houvesse tempo disponível para ficar na estação. Desse modo, os alunos não ficariam ociosos enquanto esperavam o tempo para trocar de estação mesmo tendo terminado as duas primeiras questões.

Ainda acerca da primeira coleta, vale ressaltar que ela foi pensada para ser apenas a primeira etapa de uma série de atividades que despertariam o interesse dos alunos antes de pedir para que eles respondessem o questionário. No entanto, a fim de que houvesse uma primeira reflexão após o término da aula, os alunos responderam a três perguntas que tinham relação com as atividades realizadas naquele dia:

\section{Para refletir}

1. Quais elementos do livro didático das estações anteriores você não conhecia?
( )Índice
( )Wortliste
()Einstiegseite
( )Divisão das lições em módulos
( )Objetivos (Lernziele)
Outros

2. Qual desses elementos você gostaria de conhecer mais? Explique.

3. Como você percebe que aproveitou o conteúdo aplicado em aula?

( ) quando consigo fazer os exercícios

( ) quando consigo usar determinada estrutura ao falar

( ) quando escuto alguém falando e identifico uma palavra ou estrutura que aprendi

( ) quando tiro boas notas na prova

Outro

Procure explicar a sua opinião: 


\section{Segunda coleta de dados}

A partir dos elementos fornecidos pelos alunos durante essa primeira etapa e das respostas obtidas a partir dessa primeira atividade de reflexão, a segunda etapa da coleta de dados - realizada em 10 de maio de 2017 - também foi organizada em forma de estações. Dessa vez, foram pensadas três estações que tratavam de aspectos específicos apontados pelos alunos durante a primeira coleta. Nesse sentido, as três estações desenvolvidas foram:

- Estação 1: EINSTIEGSSEITEN und DAS KANN ICH SCHON

\section{Materiais na mesa:}

Kursbuch, revistas, papéis coloridos e folhas de sulfite, cola, fita adesiva.

\section{Orientações.}

1. Observem as EINSTIEGSSEITEN e as seções DAS KANN ICH SCHON de cada um dos blocos temáticos do Kursbuch do livro Planet e respondam (anotem suas conclusões na folha branca sobre a mesa, usem uma caneta para escrever suas observações):
a. Para que servem as Einstiegsseiten? Que elementos elas trazem? Vocês consideram essa parte do livro importante e útil para a aula? (resposta no envelope verde)
b. Em que momentos aparecem as seções DAS KANN ICH SCHON? Para que vocês acreditam que essa seção pode ser usada? Isso diz algo sobre a estrutura do livro? (resposta no envelope verde)

2. Usem a sua criatividade e, junto com os colegas do grupo, montem uma versão de uma EINSTIEGSSEITE para os capítulos 17 a 20. Utilizem a folha verde

3. Caso vocês ainda tenham tempo: Qual das duas páginas (EINSTIEGSSEITE ou DAS KANN ICH SCHOM) vocês consideram que é mais importante? - Discutam e escrevam suas conclusões na folha azul.

Quadro 7: Enunciados da primeira estação - segunda coleta

- Estação 2: Übungen im Arbeitsbuch

\section{Materiais na mesa}

Arbeitsbücher, réguas, cola, fita adesiva, canetinhas, papéis, revistas

\section{Orientações}

1. Observem a unidade 19 do Arbeitsbuch e reflitam (anotem suas conclusões na folha branca sobre a mesa, usem uma caneta para escrever suas observações):

a. Existe alguma ordem na escolha em que os exercícios aparecem? É possível perceber algum tipo de ligação com o que foi visto no Kursbuch? (resposta no envelope verde) 
b. A página inicial das unidades do Arbeitsbuch e a seção intitulada DAS HAST DU GELERNT são também exercícios ou têm outro tipo de função? (resposta no envelope verde)

2. Junto com seu grupo, montem na folha amarela dois exemplos de como seriam exercícios ideais para você. Para facilitar, escolham um dos temas já estudados em aula.

3. Caso vocês ainda tenham tempo: em que momentos o Arbeitsbuch poderia ser utilizado para estudar? Vocês consideram importante utilizálo em aula? Escrevam suas conclusões na folha azul

Quadro 8: Enunciados da segunda estação - segunda coleta

- Estação 3: Wörterbücher

\section{Materiais na mesa}

Dicionários/ cópias aumentadas das páginas

\section{Instruções}

1. Observem o dicionário desde as páginas iniciais e também as páginas finais. Vocês acham que o dicionário serve apenas para procurar palavras desconhecidas? O que mais pode ser encontrado? - Anotem suas conclusões na folha branca que está sobre a mesa. (resposta no envelope verde)

2. Observem a página do dicionário que está na mesa. Escolham algumas das palavras e indiquem a função dos símbolos e siglas que acompanham os verbetes. Anotem suas conclusões na folha rosa.

3. Caso vocês ainda tenham tempo: Quando vocês acham que o dicionário é útil? Ele deve ser utilizado durante a aula? Em que momento? Escrevam suas conclusões na folha azul.

Quadro 9: Enunciados da terceira estação - segunda coleta

A estação três que tratava sobre o uso de dicionários foi desenvolvida levando em consideração as próprias respostas dos alunos na atividade "Para Refletir" e a sua necessidade em utilizar esse recurso durante as aulas. Ao final destas atividades, a primeira etapa do questionário foi aplicada aos alunos.

\section{Terceira coleta de dados}

A terceira etapa da coleta de dados, realizada em 07 de junho de 2017, ocorreu de forma similar às demais, no entanto, ela tratava sobretudo sobre o próprio processo de aprendizagem dos alunos em relação à língua alemã e aos seus estudos no CEL. Para tal, eles foram divididos em três grupos para que eles trabalhassem com a parte previamente dividida de uma Sprachbiographie de uma 
aluna da graduação em alemão da FFLCH, que iniciou seus estudos em alemão em uma unidade do CEL.

O objetivo era que, ao final, os alunos pudessem comparar a refletir sobre 0 seu próprio percurso de estudos com a língua alemã, além de refletir sobre seus conhecimentos em outras línguas estrangeiras. Cada um dos grupos tratava sobre um tema específico e, ao final, todos ouviram a atividade feita pelo colega de modo a ter contato com todas as partes da Sprachbiographie utilizada como base da atividade.

Neste caso, apesar de receberem textos de apoio e perguntas diferentes, todos os grupos receberam as mesmas instruções:

1. Junto com seus colegas, façam um pequeno resumo desse texto (em alemão)

2. Comparem o que está escrito no texto com as suas experiências e escrevam suas conclusões na folha que está sobre a mesa com a identificação do grupo (em alemão).

3. Respondam às questões que estão no slide sobre a mesa (em alemão).

4. Façam oralmente um resumo do texto que você leu para os demais colegas da sala (em alemão).

Quadro 10: Atividades para todos os grupos na terceira coleta

Os grupos, bem como os textos de apoio utilizados por cada dupla foram divididos da seguinte forma:

- Grupo 1 - Muttersprache und Fremdsprachen

\section{Muttersprache ${ }^{22}$}

Meine Muttersprache ist brasilianische Portugiesisch. Ich bin in São Paulo(SP), Brasilien geboren und seitdem wohne ich in der Stadt. Mein Vater kommt aus Bahia, trotzdem hat er keinen starken Akzent; meine Mutter kommt aus São Paulo. Deswegen spreche ich den ,Paulistano“ Dialekt.

\footnotetext{
${ }^{22}$ O texto utilizado na terceira etapa da coleta de dados é uma produção original feita por uma aluna da graduação em alemão da FFLCH/ USP. O texto não foi corrigido antes de ser entregue aos alunos do CEL por motivos didáticos para que eles, caso notassem algum desvio, pudessem refletir que o erro faz parte do processo de aprendizagem e que existem diferentes níveis de domínio de uma LE. Além disso, como a aluna iniciou seus estudos de alemão em uma unidade do CEL, a não correção do texto teve também como objetivo incentivar os alunos que porventura poderiam ficar surpreendidos com a capacidade de produção de uma exaluna do $\mathrm{CEL}$, mesmo que houvesse alguns erros.
} 


\section{Fremdsprache}

Es ist schwer zu wissen, welche meine erste Fremdsprache war, weil ich in der Schule Englisch und Spanisch Unterricht hatte. Die Unterrichtstunde waren nicht so gut, aber ich habe etwas gelernt. Ausserdem hörten meine Eltern gern internationale Musik, insbesondere Musik auf Englisch. Deshalb hatte ich als Kind Kontakt mit Englisch auch ausser die Schule. Als ich 9, 10 Jahre alt war, schaute ich die mexicanische Seifenoper „Rebelde“ an und hörte die Musik der Band „RBD“ auf Spanisch, und begann ich mich auch für amerikanische und englische Musik zu interessieren - wegen Disney Channel und Pop Musik. Deswegen kann ich nicht klar sagen, ob Englisch oder Spanisch meine erste Fremdsprache war.

\section{Perguntas:}

Teil 1: Meine erste(n) Sprache(n)

1. Mit welchen Sprachen bin ich aufgewachsen?

2. Wie hatte ich Kontakt zu diesen Sprachen? Wer hat mit mir diese Sprachen gesprochen?

\section{Teil 2: Meine Fremdsprachen}

1. Welche Sprachen habe ich in der Schule gelernt?

2. Wie war der Unterricht? (Dauer, Intensität, Materialien, Aktivitäten, usw.)

3. Habe ich außerhalb der Schule weitere Sprachen gelernt? Wo und wie?

4. Wann und wie benutze ich meine Fremdsprachen heute? (z.B. bei der Arbeit, im Studium, im Bekanntenkreis, auf Reisen)

Quadro 11: Atividades do primeiro grupo - terceira coleta

- Grupo 2 - Wie ich am besten Sprachen lerne?

\section{Wie ich am besten Sprachen lerne?}

Ich habe Motor-Speicher, deswegen lerne ich sehr beim schreiben. Das war mir sehr wichtig, als ich den Kurs im CEL gemacht habe, weil dabei konnte man kein Buch nach Hause mitnehmen. Darum musste ich viel kopieren und schreiben. Aber ich denke, dass es mir nur im A1 und A2 Niveau klappt, weil zurzeit ist es nicht so. Ich denke, dass heutzutage ich die Sprache nicht nur durch die Sprache lerne. Was ich meine ist, dass ich lerne am besten, wenn die Sprache ein Hilfsmittel um etwas anders zu verstehen oder lernen ist, z.B. beim Aquisição/Aprendizagem de Alemão como Língua Estrangeiras Unterricht. Dabei MUSS ich Texte auf Deutsch lesen und viel auf Deutsch schreiben und hören und sprechen. Dabei verweigern ich mich auf Portugiesisch zu sprechen oder schreiben und damit lerne ich sehr. 
Obwohl ich die Deutsche Sprache sehr mag, habe ich nicht viele Selbstmotivation um allein zu lernen. Deswegen besuche ich immer noch Kurse und Seminaren an der Uni, in denen ich viel Kontakt mit dem Deutschen habe und die Sprache üben muss. Ich versuche auch deutsche Musik zu hören und Nachrichten auf Deutsch zu schauen und lesen - insbesondere Nachrichten, deren Themen ich gut kenne. Ausserdem skype ich oft mit meinen Deutschen Freunden, um meine Fähigkeiten beim Sprechen zu verbessern

\section{Perguntas:}

1. Welche Aktivitäten mache ich gerne, um z.B. Wortschatz, Grammatik, Aussprache, Hör- und Leseverstehen zu üben?

2. Welche Texte schreibe oder lese ich manchmal in meinen Fremdsprachen?

3. Was mache ich, um meine Fremdsprachen auch mündlich zu üben?

Quadro 12: Atividades do segundo grupo - terceira coleta

- Grupo 3 - Meine Pläne für die Zukunft.

\section{Meine Pläne für die Zukunft}

Ich will C2 Niveau in Deutsch erreichen und mein Master in Deutschland machen. Fremdsprachen zu lernen macht mir viel Spass, deswegen möchte ich auch fliessend in Spanisch und Englisch zu werden, weil ich ein Master über die Rezeption der lateinamerika Literatur in Deutschland machen will, um die brasilianische Literatur auszubreiten. Dann würde ich gern eine andere Fremdsprache lernen - vielleicht Hebräisch oder Arabisch. Hebräisch, damit ich die Bibel besser lesen kann und Arabisch, weil ich einer jordanischen Flüchtlingen Familie Portugiesisch unterrichte und die Arbeit mit Flüchtlinge insbesondere Araber - mich sehr interessiert und mir sehr gefällt. Auch wenn ich in Deutschland wohne, würde ich noch gern mit Flüchtlinge arbeiten und ihnen vielleicht Deutsch beibringen.

\section{Perguntas:}

1. Welche Sprachkenntnisse möchte ich ausbauen und warum?

2. Welche neue Sprache möchte ich vielleicht lernen und warum?

3. Wofür brauche ich die Sprachen, die ich (weiter) lernen möchte?

4. In welchen Kontexten möchte ich diese Sprachen benutzen? 
Ainda sobre a terceira etapa da coleta de dados, vale ressaltar que, antes de responderem à segunda parte do questionário, os alunos viram um vídeo da aluna autora da Sprachbiographie utilizada para o desenvolvimento das atividades. No vídeo, a aluna fala, em alemão, acerca da sua trajetória de estudos desde que frequentava as aulas no CEL. Ela também trata sobre a sua opinião acerca do LD que ela utilizava na época e dos seus planos para o futuro com a língua alemã.

\subsubsection{Aplicação das atividades}

Todas as atividades foram aplicadas durante as aulas da turma investigada. De acordo com o planejamento escolar feito no início de cada semestre, é preciso incluir alguns dias com atividades diferenciadas para as quais não necessariamente o LD é utilizado. Dessa maneira, as estações também serviram para quebrar a rotina dos alunos da turma investigada.

A preocupação inicial antes da primeira coleta tinha relação com a reação dos alunos perante às atividades realizadas. Em outras experiências com a turma, pude verificar como professor, que algumas vezes os alunos ainda não se sentiam confiantes o bastante para desenvolver atividades com um grau de autonomia suficiente de modo que o professor pudesse cumprir o seu papel de observador assim como aponta Ceccheto (cf. 2002, p. 237). Mesmo diante dessa dúvida, essa forma de trabalho foi a escolhida pelo fato de que seria uma boa maneira de despertar a curiosidade dos alunos para alguns aspectos pertinentes à aula, mas que nem sempre são discutidos abertamente, como é o caso do LD.

Para que fosse possível observar, sem interferir, as instruções dadas em cada uma das estações foram pensadas para transmitir de maneira clara e objetiva o que cada grupo deveria fazer para que, dessa forma, não fosse preciso parar em cada uma das estações para fornecer explicações além das que constavam nas instruções. Assim, houve a opção em fornecer os enunciados em português uma vez que, caso eles fossem escritos em alemão, provavelmente seria necessário interferir no trabalho dos grupos para ajudar a compreender o que estava sendo pedido. Além 
disso, fornecer enunciados em alemão demandaria mais tempo para que as atividades fossem realizadas.

Iniciada a atividade, notou-se que os alunos se empenharam em realizar tudo que era pedido e, diferente do que se esperava, não foi preciso fazer intervenções no sentido de explicar as atividades, mas sim no sentido de dizer quanto tempo disponível eles ainda tinham em cada estação.

O resultado da primeira estação do primeiro dia da coleta de dados foi tão positivo, que os próprios alunos indagaram sobre outras atividades iguais àquela. Dessa forma, tendo em vista a aceitação do grupo em relação às atividades em forma de estações, as demais também foram desenvolvidas com esse formato.

$\mathrm{Na}$ segunda etapa, os alunos já estavam mais preparados para o tipo de atividade que eles deveriam realizar. Por isso, foi mais fácil organizá-los em grupos e também não foi preciso explicar as regras do trabalho em estações já que eles mesmos, no início da aula, já haviam começado a se preparar e a separar o seu material escolar pessoal - como caneta e lápis - que seria útil durante a aula. Tendo em vista a duração das atividades durante a primeira coleta, optou-se por realizar menos estações na segunda coleta a fim dos alunos terem mais tempo disponível ao final do trabalho nas estações para responder à primeira parte do questionário.

Na última etapa da coleta, foi interessante observar a reação dos alunos ao perceber que a Sprachbiographie ${ }^{23}$ usada durante as atividades pertencia a uma estudante que tinha iniciado seus estudos em uma unidade do CEL. A impressão a partir dos comentários feitos era de que, para eles, as aulas do CEL dariam uma base tão pequena que apenas após muito estudo extra seria possível, para eles, seguir um curso superior no qual a língua alemã fosse exigida. Em outras palavras, os comentários dos alunos nesse momento apontaram para o fato de que muitos alunos não acreditavam que seria possível aprender alemão de forma efetiva no CEL.

\footnotetext{
${ }^{23}$ Além do texto utilizado como base para as atividades da terceira etapa da coleta de dados, a estudante também gravou um vídeo no qual ela relatava um pouco da sua trajetória na aprendizagem de alemão desde a época em que estudava no CEL. O vídeo foi exibido para os alunos no final das atividades.
} 


\subsection{Questionário: desenvolvimento e aplicação}

Nesta seção, justificarei o uso do questionário a partir dos pressupostos de Dörnyei (2003). Após essa breve justificativa, abordarei de forma específica o processo de construção bem como a aplicação deste questionário para o grupo investigado.

\subsubsection{Justificativa do uso de questionários}

Para a elaboração do questionário, levei em consideração os apontamentos de Dörnyei (2003), que trata sobre esse tipo de recurso para pesquisas em segunda língua.

De acordo com Dörnyei (2003, p.3), "perguntar é uma das formas mais naturais de se obter informação ${ }^{24 "}$. Assim, com o intuito de coletar diversas respostas dos alunos de alemão do CEL na turma investigada, decidi que a melhor forma de fazê-lo era justamente a partir de um questionário levando em consideração as vantagens oferecidas por essa ferramenta em relação a prazos (cf. DÖRNYEI, 2003, p. 9) e, sobretudo, devido ao fato de que era esperado que os alunos, mesmo que tivessem pouca ou nenhuma experiência com um questionário, se sentissem à vontade para responder perguntas naquele formato.

O autor também aponta para o fato de que um questionário é uma ferramenta que, apesar de útil, apresenta uma série de particularidades que devem ser observadas quando da sua elaboração. O próprio termo "questionário", apesar de familiar, é de difícil definição assim como indica Dörnyei (cf. 2003, p.5), tendo em vista que existem diversos formatos possíveis. Nesse sentido, ao elencar tipologias possíveis que se enquadram como questionários, Dörnyei aponta os seguintes formatos: inventários, formulários, testes, tabelas ou simplesmente folhas, dentre outros (cf. DÖRNYEI, 2003, p. 5).

\footnotetext{
${ }^{24}$ No original: "Asking is one of the most natural ways of gathering information"
} 
Citando Brown (2001), Dörnyei afirma que questionários podem ser definidos como:

Quaisquer instrumentos escritos que apresentam aos respondentes uma série de afirmações às quais eles devem reagir, ou escrevendo suas respostas, ou selecionando-as a partir de respostas existentes ${ }^{25}$. (BROWN, 2001, p. 6 apud DÖRNYEI, 2003, p. 6)

Ainda em relação aos questionários, vale ressaltar que não há respostas corretas ou incorretas. Contudo, é necessário que os respondentes reflitam acerca das respostas fornecidas de modo a oferecer dados consistentes e que mostrem a opinião de quem está respondendo o questionário. Dessa maneira, aquele que deseja elaborar um questionário deve cuidar para que a sua visão não influencie na elaboração de perguntas que de certa forma levem os respondentes a fornecer exatamente a informação que se deseja obter.

Sobre as vantagens de se utilizar um questionário, Dörnyei elenca vantagens de tempo, de esforço e econômicas para o pesquisador. No entanto, o autor também faz uma série de observações em relação às desvantagens da utilização de questionários como, por exemplo, a superficialidade de algumas respostas obtidas, a desmotivação dos informantes em fornecer respostas e a falta de compromisso com a verdade nas respostas fornecidas pelos informantes. Tais desvantagens foram observadas, por exemplo, durante a pilotagem realizada.

Nesse sentido, apresentarei na próxima seção os passos que levaram à elaboração do questionário até a sua versão final que foi respondida pelos participantes da pesquisa.

\subsubsection{Elaboração do questionário}

A primeira preocupação acerca do questionário estava diretamente relacionada com os respondentes da pesquisa. Como se trata de jovens com uma

\footnotetext{
${ }^{25}$ No original: "Questionnaires are any written instruments that present respondents with a series of questions or statements to which they are to react either by writing out their answers or selecting from among existing answers".
} 
média de idade variando entre os 15 e os 17 anos, acreditava-se que o questionário não deveria ser longo a fim de que os participantes não se cansassem de respondêlo de forma a fornecer respostas vagas apenas com o intuito de responder todas as perguntas o mais rápido possível como tinha sido verificado durante a pilotagem realizada anteriormente. Assim, a primeira escolha metodológica feita é que o questionário seria aplicado em duas etapas as quais, por sua vez, seriam realizadas após a aplicação de atividades didáticas como foi descrito na seção anterior.

Após o momento em que foi decidido que o questionário seria aplicado em duas partes, foi necessário estabelecer os pontos gerais que serviriam para 0 desenvolvimento das perguntas. Nesse sentido, a primeira atividade didática serviu apenas de suporte para verificar como os alunos reagiriam à oportunidade de lidar com informações sobre o LD e sobre o seu próprio processo de aprendizagem da língua alemã. A atividade final proposta naquele dia que era justamente um exercício de reflexão acerca desses temas que haviam sido abordados ao longo das quatro estações e serviu de suporte para que fossem definidos três grandes blocos temáticos para o questionário:

1 - Dados pessoais e histórico de aprendizagem de LE;

2 - LD na sala de aula;

3 - Autonomia e estudo em casa.

Como o questionário seria aplicado em duas etapas, era necessário decidir qual desses blocos seria dividido. Dessa forma, para que não houvesse quebra de raciocínio por parte dos respondentes ou, ainda, para que não houvesse nenhum prejuízo quanto algum dado específico que havia sido abordado em alguma atividade didática, considerou-se que seria conveniente dividir a parte um (Dados pessoais e histórico de aprendizagem de LE) entre as duas etapas do questionário.

A parte um (dados pessoais e histórico de aprendizagem de LE) possui dez perguntas no total, as quais foram divididas em duas partes: quatro perguntas na primeira etapa e seis na segunda etapa da aplicação do questionário. 


\section{Questionário 1}

Parte 1: Dados pessoais e histórico de aprendizagem de LE

1) Nome:

2) Idade:

3) Ainda frequenta o ensino fundamental ou médio?

( ) sim, o ensino fundamental

( ) sim, o ensino médio

( ) não

4) Em uma escala de 1 a 4, onde 1 representa "baixo" e 4 representa "alto", qual é, na sua opinião, o seu desempenho com a língua alemã nas aulas do CEL?

Baixo ( 1 ) ( 2 ) ( 3 ) ( 4 ) alto

\section{Parte 2: LD na sala de aula}

5) Na sua sala, há exemplares em quantidade suficiente do livro didático para todos os alunos usarem durante as aulas?
( ) $\operatorname{sim}$
( ) não

6) Você acredita que a quantidade de livros didáticos disponíveis pode ajudar ou prejudicar a aula de alguma forma? Procure explicar a sua opinião.

7) Em uma escala de 1 a 6, qual a importância que você atribui ao livro didático para a aula de alemão? 1 representa "pouca importância" e 6 representa "muita importância"

Pouca importância ( 1 ) ( 2 ) ( 3 ) ( 4 ) ( 5 ) ( 6 ) Muita importância

8) Em relação ao tempo, qual a porcentagem da aula que costuma ser preenchida com o uso do livro didático?
( ) menos de $20 \%$
( ) entre 20 e $40 \%$
( ) entre 40 e $60 \%$
( ) entre 60 e $80 \%$
( ) mais de $80 \%$

9) Em uma escala de 1 a 6, onde 1 representa "pouco satisfeito" e 6 representa "muito satisfeito", qual é o seu grau de satisfação com o livro didático utilizado nas aulas de alemão?

$$
\text { Pouco satisfeito ( } 1 \text { ) ( } 2 \text { ) ( } 3 \text { ) ( } 4 \text { ) ( } 5 \text { ) ( } 6 \text { ) muito satisfeito }
$$

10) Procure explicar a sua opinião sobre a questão 9. 
Nas questões 11 e 12, complete as afirmações (sublinhe o conector que será utilizado na sua resposta):

11) Gosto do livro didático quando/ pois:

12)Não gosto do livro didático quando/ pois:

13) Em uma escala de 1 a 6 , onde 1 representa "pouco" e 6 representa "muito", qual é a importância que você atribui ao livro didático para você durante a aula de alemão?

$$
\text { Pouco ( } 1 \text { ) ( } 2 \text { ) ( } 3 \text { ) ( } 4 \text { ) ( } 5 \text { ) ( } 6 \text { ) Muito }
$$

14) Você acha que a aula de alemão fica melhor quando todos os alunos possuem um exemplar? Em que sentido? Justifique brevemente

15) Você já pensou sobre como seria um livro didático ideal? Procure explicar sua opinião.

Quadro 14: Perguntas do primeiro questionário

Nesta parte, foram elaboradas questões abertas para que o respondente cedesse informações de forma mais livre e perguntas fechadas de múltipla escolha que tinham como objetivo principal saber onde esses alunos já haviam estudado e quais eram seus conhecimentos em outras línguas estrangeiras, por exemplo.

A parte dois (LD na sala de aula), que foi aplicada na primeira etapa do questionário, possui dez perguntas as quais, por sua vez são abertas, fechadas e também em forma de escala. Em relação às escalas, optou-se por sempre fornecêlas com um número par a fim de evitar que os alunos, talvez por questões visuais, optassem sempre pelo valor intermediário. O grande objetivo com esse bloco de questões era permitir aos respondentes que eles refletissem sobre o uso do LD nas aulas de alemão no CEL e, ainda, verificar se os respondentes consideram ou não esse material importante para a aula.

A parte três (autonomia e estudo em casa) possui 12 perguntas abertas, fechadas, em forma de escala e de múltipla escolha que permitem a escolha de mais de uma opção. 


\section{Questionário 2}

Parte 1: Dados pessoais e relação com aprendizado de LE

1) Nome:

2) Você já estudou alemão em outra instituição, além do CEL? Em caso afirmativo, indique a instituição e a duração do curso.
( ) $\operatorname{sim}$
( ) não

3) Além do alemão, em quais outras línguas você possui algum tipo de conhecimento? (você pode assinalar mais de uma alternativa)
( ) inglês
( ) espanhol
( ) francês
( ) italiano
( ) outros:

4) Você já frequentou aulas de outro idioma em alguma outra instituição? (Em caso afirmativo, indique a instituição, a duração do curso e o idioma estudado)
( ) $\operatorname{sim}$
( ) não

5) Como você ficou sabendo do curso de alemão no CEL?

6) Por que você decidiu se inscrever para o curso?

\section{Parte 2: Autonomia e estudo em casa}

7) Você possuí uma cópia do livro didático (Kursbuch e Arbeitsbuch) em casa? (você pode assinalar mais de uma opção)
( ) sim, o Kursbuch original
( ) sim, o Kursbuch em pdf
( ) sim, o Kursbuch impresso
( ) sim, o Arbeitsbuch original
( ) sim, o Arbeitsbuch em pdf
( ) sim, o Arbeitsbuch original
( ) sim, o Arbeitsbuch impresso
( ) não, não possuo os livros

8) Em uma escala de 1 a 6 em que 1 representa "pouca importância" e 6 representa "muita importância", qual é, na sua opinião a importância de se ter uma cópia do livro didático em casa.

$$
\text { Pouca importância (1) (2) (3) (4) (5) (6) Muita importância }
$$

9) Procure explicar a sua opinião sobre a questão 8: 
10) Você costuma estudar alemão em sua casa com frequência?
( ) $\operatorname{sim}$
( ) não

11) Quantas horas, em média, você estuda alemão em casa por semana?
( ) menos de 1 hora
( ) entre 2 e 4 horas
( ) entre 4 e 6 horas
( ) entre 6 e 8 horas
( ) mais de 8 horas

12) Como você estuda em casa? Procure dar exemplos concretos sobre a sua rotina de estudos em relação ao alemão.

13) Quais dos materiais abaixo você utiliza para estudar em casa?
( ) o livro didático
( ) dicionários (impressos ou online)
( ) listas de palavras
( ) aplicativos de celular
( ) outros livros didáticos diferentes do usado em aula* (assinalando essa alternativa, responda a questão 14)
( ) outros:

14) Quais são os outros livros didáticos que você costuma utilizar para estudar alemão em casa?

15) Enumere o grau de importância que você atribui aos materiais de estudo usados em casa utilizando os materiais listados na pergunta anterior e outros que você considerar importantes. O número 1 representa 0 material mais importante e o número 4 , o menos importante.

(1)

(2)

(3)

(4)

16) Como você avalia o seu grau de autonomia para estudar alemão em casa? 1 representa "pouco autônomo" e 6 representa "muito autônomo".

Pouco autônomo (1) (2) (3) (4) (5) (6) muito autônomo

17) Na sua opinião, o que significa ser autônomo no estudo de uma língua estrangeira?

Nesta parte, as perguntas tratam sobre a forma como os alunos estudam alemão em casa e o que usam para isso. Um dos objetivos dessa parte do 
questionário era verificar se os alunos que disseram considerar o LD importante na parte dois, diriam que fazem uso desse material para estudar em casa. Além disso, era preciso verificar se os respondentes afirmariam ter cópias dos livros utilizados em aula devido ao fato de que os exemplares disponíveis não podem ser levados para casa assim como já foi descrito anteriormente. Outras perguntas exploram também a importância atribuída ao fato de se ter ou não um exemplar do LD em casa e, ainda, a quantidade de horas semanais dedicadas ao estudo de alemão fora da aula.

\subsubsection{Aplicação do questionário}

A primeira etapa do questionário foi aplicada no dia 10 de maio de 2017 durante a aula. Como a turma analisada tem quatro aulas semanais com duração de 50 minutos cada, que são oferecidos em apenas um dia da semana, o questionário foi aplicado após o final de três aulas nas quais os alunos estavam realizando as atividades didáticas já descritas anteriormente. Nesse sentido, os alunos tiveram cerca de 50 minutos para responder às 15 questões que compunham esta primeira etapa do questionário.

Apesar de já terem participado de atividades didáticas e de reflexão aplicadas em março e, ainda, apesar de terem sido informados de que o questionário fazia parte de um projeto de pesquisa e que as respostas seriam utilizadas para fins acadêmicos, alguns comentários feitos pelos alunos indicaram que eles não estavam ainda totalmente dispostos a ceder informações. Alguns, por exemplo, comentaram que o pesquisador, no caso, o próprio professor, daria risadas ao ler as respostas.

Quanto à segunda etapa do questionário, aplicada no dia 07 de junho de 2017, não se notou a mesma atitude dos alunos em relação ao processo de ceder informações, no entanto, enquanto respondiam às 18 perguntas durante um pouco mais de uma hora, alguns se disseram não inspirados para escrever algo coerente. Dessa forma, mesmo que diferente, a atitude dos alunos demonstra em certa medida o fato de que estes não estão acostumados a refletir acerca de seu próprio 
processo de aprendizagem e, além disso, o fato de afirmarem que precisam de inspiração para responder as perguntas indica uma tendência a querer produzir respostas que agradem ao pesquisador e não necessariamente que reflitam o que eles sentem. Devido a isso, algumas perguntas podem aparecer mais de uma vez com um formato diferente a fim de realmente confirmar a opinião do respondente acerca de um tópico específico. Dessa forma, se em alguma escala, por exemplo, o respondente afirmar um valor alto, posteriormente, a mesma pergunta apareceu de maneira aberta a fim de que seja possível verificar se aquela resposta anterior reflete realmente a opinião do aluno. 


\section{Apresentação dos dados}

O objetivo deste capítulo é apresentar de forma organizada os dados obtidos nos questionários aplicados durante a coleta realizada ao longo de 2017. Cabe ressaltar que, apesar da coleta ter consistido na elaboração e aplicação de atividades didáticas aplicadas em estações, a análise foi baseada, sobretudo, nos dados obtidos a partir dos questionários. Dessa forma, optou-se pela apresentação detalhada desses dados obtidos com os questionários. Os enunciados das atividades realizadas pelos alunos durante as estações, bem como as suas respostas, estão disponíveis nos anexos deste trabalho.

\subsection{Primeiro questionário}

O primeiro questionário - aplicado no dia 10 de maio de 2017 - é constituído de duas partes com um total de 15 perguntas. A primeira parte - dados pessoais e histórico de aprendizagem de LE - possui 4 questões e a segunda - LD na sala de aula - possui 11 perguntas. 8 alunos participaram desta etapa da coleta de dados: A2, A5, A6, A7, A10, A11, A12 e A14.

\subsubsection{Primeira parte do primeiro questionário}

A primeira parte do questionário tratava acerca de dados pessoais dos alunos. A primeira pergunta servia de espaço para que os alunos escrevessem seus nomes. A segunda pergunta, por sua vez, perguntava a idade dos respondentes:

\begin{tabular}{|c|c|}
\hline Idade & Quantidade de respondentes \\
\hline 14 anos & 1 \\
\hline 15 anos & 1 \\
\hline 16 anos & 3 \\
\hline 17 anos & 1 \\
\hline 18 anos & 2 \\
\hline
\end{tabular}


Complementando a informação obtida na questão anterior, a questão 3 pergunta se os alunos ainda frequentam o ensino fundamental ou médio:

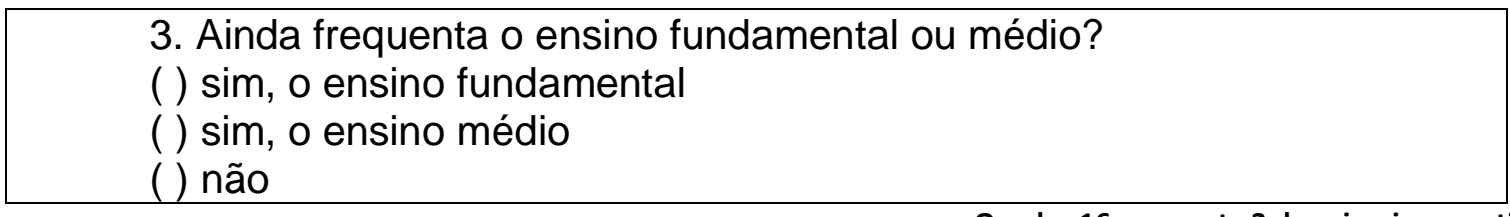

Quadro 16: pergunta 3 do primeiro questionário

Dos oito respondentes, três já não frequentavam mais o ensino médio. Isso se deve a uma questão burocrática do CEL que permite que os alunos, mesmo não frequentando mais a escola, possam concluir seu curso, uma vez que ele tenha sido iniciado durante o período do ensino fundamental ( $7^{\circ}$ ano) ou médio, de acordo com a resolução SE 44 de 13 de Agosto de $2014^{26}$. Os demais respondentes estavam em alguma das séries do ensino médio.

A quarta pergunta questionava os alunos acerca do seu desempenho com a língua alemã no CEL. A resposta deveria ser dada a partir de uma escala:

4. Em uma escala de 1 a 4 , onde 1 representa "baixo" e 4 representa "alto", qual é, na sua opinião, o seu desempenho com a língua alemã nas aulas do CEL?

Baixo (1) ( 2) ( 3$)(4)$ alto Quadro 17: pergunta 4 do primeiro questionário

As respostas para essa pergunta foram:

\begin{tabular}{|c|c|}
\hline Nível de rendimento & Quantidade de respondentes \\
\hline 1 & 0 respondentes \\
\hline 2 & 3 respondentes \\
\hline 3 & 4 respondentes \\
\hline 4 & 1 respondente \\
\hline
\end{tabular}

Tabela 3: respostas da pergunta 4 do primeiro questionário

\subsubsection{Segunda parte do primeiro questionário}

As perguntas 5 e 6 do questionário tratavam sobre um tema central para a pesquisa e tinham como objetivo averiguar a percepção dos alunos em relação à

\footnotetext{
${ }^{26}$ Disponível em: http://www.educacao.sp.gov.br/lise/sislegis/detresol.asp?strAto=201408130044
} 
presença do LD nas aulas de alemão. Nesse sentido, a pergunta 5, uma pergunta em que a resposta obtida seria sim ou não, questionava os respondentes acerca da quantidade de LD presentes para uso durante as aulas de alemão, tendo em vista o contexto de aprendizagem específica do CEL assim como foi disposto no capítulo de metodologia:

5. Na sua sala, há exemplares em quantidade suficiente do livro didático para todos os alunos usarem durante as aulas?

( ) $\operatorname{sim}$

( ) não

Quadro 18: pergunta 5 do primeiro questionário

Aqui, mesmo participando do mesmo contexto de aprendizagem, não houve consenso entre os respondentes. Entre os oito alunos que preencheram 0 questionário, seis assinalaram a resposta "sim" e dois a resposta "não".

Seguindo nesse raciocínio, a pergunta 6 pedia para que os alunos explicassem se a quantidade de livros poderia influenciar a aula, tanto positivamente, quanto negativamente:

6. Você acredita que a quantidade de livros didáticos disponíveis pode ajudar ou prejudicar a aula de alguma forma? Procure explicar a sua opinião.

Quadro 19: pergunta 6 do primeiro questionário

As respostas obtidas foram as seguintes:

- A2 - „sim“ na pergunta 5

Se houver uma quantidade que todos os alunos possuam um livro ajuda, se não houver livros suficientes pode prejudicar. Sem os livros o aluno terá que dividir com o colega, coisa que pode ser ruim se a dinâmica do outro for diferente.

- A5 - "sim" na pergunta 5

Pode ajudar, pois se tem o livro pra todos não tem muitas conversas paralelas, e o aluno se concentra mais.

- A6 - "não" na pergunta 5

Devido ter poucos livros somos prejudicados em relação ao aprendizado individual.

- A7 - "não" na pergunta 5

A quantidade é boa de livros, não prejudica.

- A10 - "sim" na pergunta 5

Creio que a quantidade não interfere tanto, devido à quantidade de alunos. 
- A11 - "sim" na pergunta 5

Em partes sim, diante do período de tempo que temos, as vezes, torna a aprendizagem maçante, porém, grande parte da utilização dos livros didáticos faz com que a aula fique mais "explicativa", fazendo com que fique mais fácil aprender e "interagir" com a língua alemã.

- A12 - "sim" na pergunta 5

Claramente sim, pois o livro se torna uma das principais ferramentas, juntamente com o professor, para o aprendizado de um novo idioma, o que de certa forma é abstrato. Sendo assim, ter algo já com a finalidade do aprendizado assim como o livro é essencial.

- A14 - "sim" na pergunta 5

Ajudar, pois ira facilitar o aprendizado individual.

A pergunta 7 pede para que os alunos preencham uma escala que representa a importância atribuída por eles em relação ao LD para a aula de alemão:

7. Em uma escala de 1 a 6 , qual a importância que você atribui ao livro didático para a aula de alemão? 1 representa "pouca importância" e 6 representa "muita importância"

Pouca importância (1) ( 2 ) ( 3 ) ( 4 ) ( 5 ) ( 6 ) Muita importância Quadro 20: pergunta 7 do primeiro questionário

As respostas obtidas foram:

\begin{tabular}{|c|c|}
\hline Respondente & Valor escolhido \\
\hline A2 & 5 \\
\hline A5 & 4 \\
\hline A6 & 5 \\
\hline A7 & 5 \\
\hline A10 & 5 \\
\hline A11 & 5 \\
\hline A12 & 5 \\
\hline A14 & 4 \\
\hline
\end{tabular}

Tabela 4: respostas da pergunta 7 do primeiro questionário

Vale notar que é alta a importância atribuída ao LD para as aulas, já que grande parte dos respondentes escolheu o número 5 em uma escala que ia ate 0 número 6.

A pergunta 8 questionava os respondentes acerca da quantidade de tempo da aula preenchido com a utilização do LD: 
8. Em relação ao tempo, qual a porcentagem da aula que costuma ser preenchida com o uso do livro didático?

( ) menos de $20 \%$

( ) entre 20 e $40 \%$

( ) entre 40 e $60 \%$

( ) entre 60 e $80 \%$

( ) mais de $80 \%$

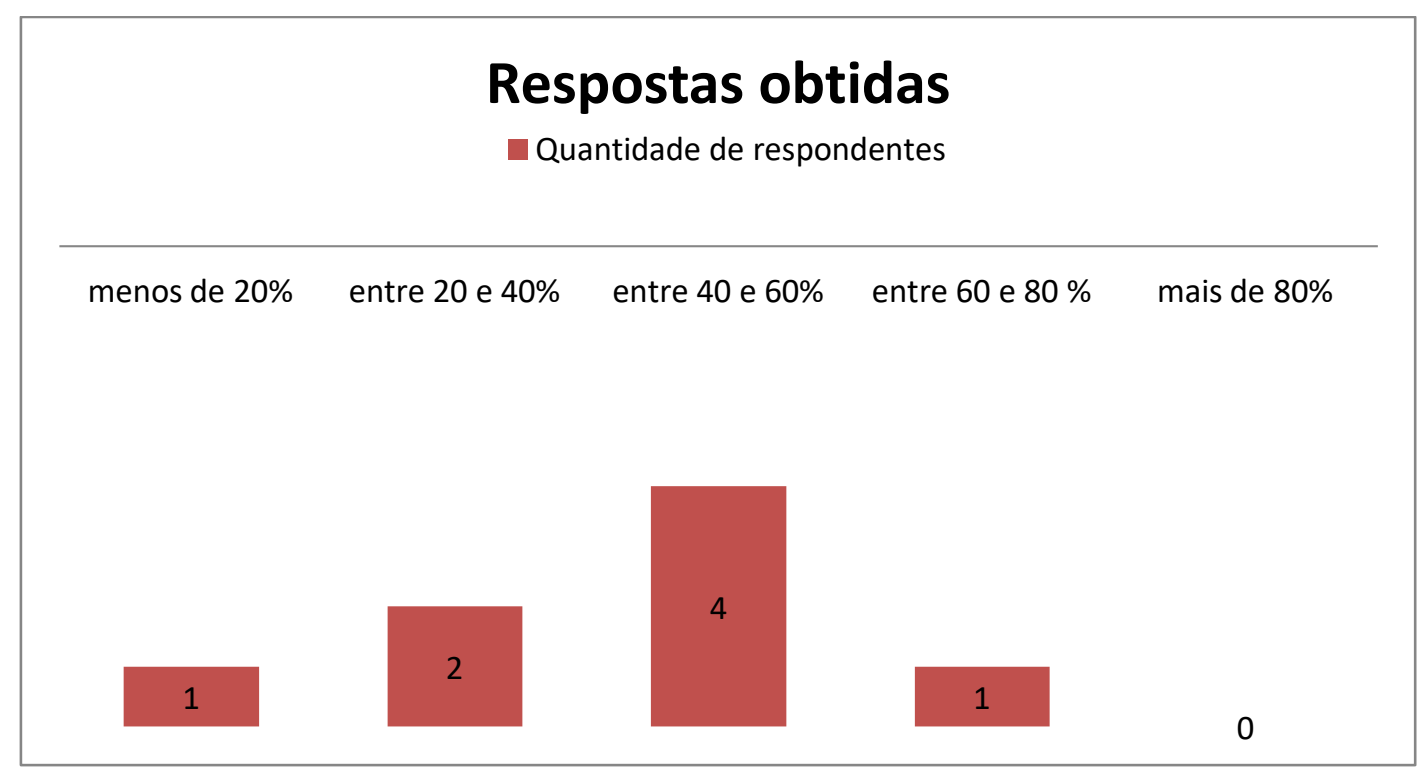

Gráfico 1: respostas da pergunta 8 do primeiro questionário

As perguntas 9 e 10 também se complementam, uma vez que a pergunta nove apresenta uma escala que trata sobre a satisfação pessoal de cada respondente em relação ao LD utilizado e a pergunta dez pede para que o respondente explique a sua opinião:

9. Em uma escala de 1 a 6 , onde 1 representa "pouco satisfeito" e 6 representa "muito satisfeito", qual é o seu grau de satisfação com o livro didático utilizado nas aulas de alemão?

Pouco satisfeito ( 1 ) ( 2 ) ( 3 ) ( 4 ) ( 5 ) ( 6 ) muito satisfeito 
Nesta pergunta, os respondentes forneceram as seguintes respostas:

\begin{tabular}{|c|c|}
\hline Respondente & Valor escolhido \\
\hline A2 & 4 \\
\hline A5 & 4 \\
\hline A6 & 5 \\
\hline A7 & 5 \\
\hline A10 & 6 \\
\hline A11 & 5 \\
\hline A12 & 4 \\
\hline A14 & 4 \\
\hline
\end{tabular}

Tabela 5: respostas da pergunta 9 do primeiro questionário

Já em relação à pergunta 10 "Procure explicar a sua opinião sobre a questão 9", as respostas obtidas foram:

- $\mathrm{A} 2$ O livro possui algumas lições que exigem um pouco mais de atenção que outras, porém, outras são bem explicadas ou possuem enunciados mais simples, fáceis de entender.

- A5

Para mim é 4, pois tem vezes que não entendo um tema e fico um "pouco satisfeito".

- A6

O livro é bem ilustrativo e de fácil compreensão sempre nos apresenta a temática e no fim de cada unidade há uma pequena revisão do que aprendemos.

- A7

O livro é bom só que precisamos de mais exercícios específicos.

- A10

O livro aborda de maneira prática o conteúdo demonstrado, além disso, o mesmo traz figuras que facilitam o entendimento, além de dicas e vocabulários úteis/ necessários.

- A11

Quaisquer que for o tema e/ou atividade proposta pelo livro, possui uma forma de explicar tornando o aprendizado mais fácil, porém, não são todas as atividades de fácil entendimento, fazendo com que, as vezes, confunda o aluno, não apresentando a explicação clara para prosseguir com a atividade proposta.

- $\mathrm{A} 12$

Muitas vezes enxergo que o livro didático acaba cobrando mais do que transmite ou que acaba se "fechando" em relação ao aprendizado, ou seja, o idioma parece não conter variação e ser exatamente como é descrito pelo livro didático.

- A14

Sim, no sentido de facilitar o entender da aula. O livro auxilia e reforça o conteúdo aprendido em sala. 
As perguntas 11 e 12 do questionário pediam para que os respondentes completassem duas informações:

Nas questões 11 e 12, complete as afirmações (sublinhe o conector que será utilizado na sua resposta):

11. Gosto do livro didático quando/ pois:

12. Não gosto do livro didático quando/ pois:

Quadro 23: perguntas 11 e 12 do primeiro questionário

Sobre a questão 11, foram obtidas as seguintes respostas :

- A2: QUANDO é utilizado como ferramenta de explicação

- A5: QUANDO tem exercícios fáceis e menos complexos e temas que eu não conheço

- A6: POIS é ilustrado e de fácil compreensão

- A7: QUANDO os assuntos são contínuos

- A10: QUANDO utilizado para reforçar vocabulários e como exemplo na aula

- A11: QUANDO as atividades são auto explicativas e favorecem em uma aprendizagem mais rápida.

- A12: POIS podemos considerá-lo a maneira mais explicativa e adequada para o aluno ter contato com o idioma.

- A14: POIS ele auxilia no aprendizado de uma maneira geral.

Já em relação à pergunta doze, os respondentes forneceram as seguintes respostas:

- A2: QUANDO é utilizado rapidamente e não há um aproveitamento das demais lições.

- A5: POIS alguns exercícios eu não entendo ou fique em dúvida

- A6: QUANDO tem questões muito difíceis

- A7: QUANDO de um exercício para o outro o assunto muda totalmente

- A10: QUANDO é utilizado como única fonte para a resolução de exercícios

- A11: QUANDO possui dentro de um mesmo assunto, a retomada maçante de termos, ou atividades quase "iguais"

- A12: QUANDO ele acaba misturando o que está sendo aprendido no momento (na maioria das vezes vocabulário) com o que já foi visto como os pronomes possessivos, por exemplo. Para que os dois se unam devem estar localizados no local voltado para revisão.

- A14: Não respondido

A pergunta 13 apresenta mais uma escala na qual os alunos deveriam escolher o número que representasse o grau de importância que o LD tinha para eles de forma pessoal durante as aulas de alemão: "muito", qual é a importância que você atribui ao livro didático para 


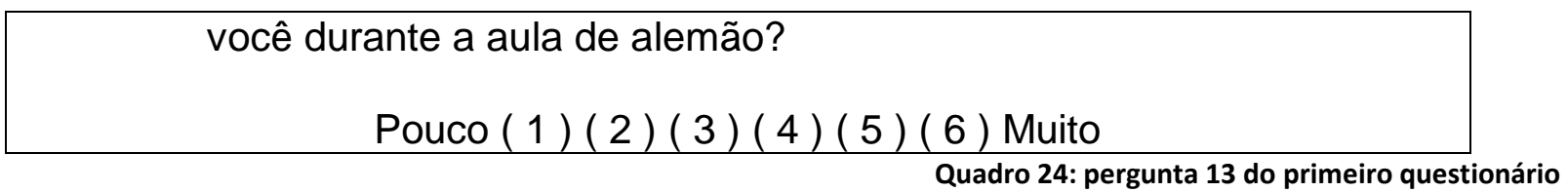

As respostas fornecidas por cada um dos respondentes foi:

\begin{tabular}{|c|c|}
\hline Respondente & Valor escolhido \\
\hline A2 & 5 \\
\hline A5 & 5 \\
\hline A6 & 4 \\
\hline A7 & 6 \\
\hline A10 & 4 \\
\hline A11 & 5 \\
\hline A12 & 6 \\
\hline A14 & 4 \\
\hline
\end{tabular}

Tabela 6: respostas da pergunta 13 do primeiro questionário

Mais uma vez, as respostas apontam para uma alta taxa de valoração do LD para os respondentes participantes da pesquisa, assim como já foi verificado anteriormente em outras perguntas desta etapa do questionário.

A pergunta 14, por sua vez, pergunta aos respondentes se a aula de alemão ficaria melhor caso todos tivessem um exemplar do LD:

14. Você acha que a aula de alemão fica melhor quando todos os alunos possuem um exemplar? Em que sentido? Justifique brevemente

Quadro 25: pergunta 14 do primeiro questionário

Quanto às respostas fornecidas pelos alunos:

- $\mathrm{A} 2$

Sim. Se todos os alunos tivessem um exemplar em mãos (onde o mesmo poderia ser levado para casa) o aproveitamento e aprendizagem das lições seria melhor.

- A5

Sim, melhora o desempenho do aluno e não precisa olhar o do colega para fazer as tarefas pedidas.

- A6

Sim, pois cada um com um exemplar fica melhor o aprendizado individual, podendo assim cada aluno tirar suas dúvidas sem ficar 
envergonhado. Muitas das vezes em que o livro é dividido alguns alunos ficam tímidos em apresentar suas dúvidas devido a sua dupla.

- $\mathrm{A} 7$

Não todos os alunos, mas tendo 2 pelo menos é bom porque existe uma atenção melhor principalmente os alunos que não tem mentes desenvolvidas.

- $\mathrm{A} 10$

Sim. Melhor em um sentido de que com exemplares, todos podem ter acesso ao auxilio provido pelo livro, além de poderem personalizar suas anotações.

- $\mathrm{A} 11$

Sim, quando todos possuem o mesmo material de apoio, fazendo com que todos participem e mantenha um certo nivelamento entre os alunos

- $\mathrm{A} 12$

Sim, pois ele adquire maior intimidade com o livro, podendo prestar mais atenção nos detalhes, por exemplo.

- $\mathrm{A} 14$

Sim, no sentido de facilitar o entender da aula. O livro auxilia e reforça o conteúdo aprendido em sala.

A última pergunta dessa parte do questionário, a pergunta 15, pede para que os alunos expliquem se eles já pensaram em como seria um LD ideal:

15. Você já pensou sobre como seria um livro didático ideal? Procure explicar sua opinião.

Quadro 26: pergunta 15 do primeiro questionário

As respostas obtidas foram diversificadas e apresentam diferentes visões dos respondentes acerca do que seria um LD ideal para as aulas de alemão. Neste ponto, vale ressaltar que há, assim como também se observou anteriormente, a grande quantidade de respostas generalizantes.

- $\mathrm{A} 2$

O livro didático ideal seriam aquele que possui imagens explicativas, pequenos resumos com palavras mais fáceis, um padrão de exercícios e com textos não muito extensos.

- A5

Nunca pensei como seria um livro ideal, pois o livro didático que temos já é suficiente para entendermos e estudar. $\mathrm{E}$ se fosse mudar uma coisa 
seria que pudéssemos levar o livro pra casa para conter mais aprendizado.

- A6

Ilustrado, separado em tópicos que aborde gramática, fonética, cultura e interpretação.

- $\mathrm{A} 7$

Nunca pensei, mas em minha opinião acho que teria que detalhar bem os exercícios para deixar bem explicado bem específico

- $\mathrm{A} 10$

Sim, um livro que pudesse ser levado para casa, e que tivesse, além de conteúdos da aula, áudios com pronúncias, resumos de matérias e indicações de filmes, séries, etc

- $\mathrm{A} 11$

Acredito que um bom livro didático é ser auto explicativo (apesar do alemão não ser uma língua de fácil entendimento), exemplificando, com uma base favorável de exercícios diferentes, um livro que estimule o debate entre os alunos, que sucumba as dúvidas e que torne mais dinâmica a aula

- $\mathrm{A} 12$

Um livro didático que além de revisar a unidade, possuíssem capítulos específicos para que tudo o que foi aprendido seja revisado. Poderia existir também unidades com o intuito da produção textual, ou até mesmo dicas do que poderíamos ler ou assistir para que possamos adquirir mais vocabulário, além do oferecido.

\subsection{Segundo questionário}

O segundo questionário que compõe os dados desta pesquisa foi aplicado no dia 07 de junho de 2017 e, assim como o questionário anterior, também apresenta duas partes. A primeira delas, constituída por seis questões, também recebeu o nome de "dados pessoais e histórico de aprendizado de LE", já a segunda parte, constituída por doze perguntas, recebeu o nome de "autonomia e estudo em casa". No total, o questionário possui 18 perguntas. Nesta etapa, sete respondentes forneceram respostas para o questionário: $\mathrm{A} 1, \mathrm{~A} 2, \mathrm{~A} 5, \mathrm{~A} 7, \mathrm{~A} 10, \mathrm{~A} 11$ e A12.

\subsubsection{Primeira parte do segundo questionário}

A primeira pergunta do segundo questionário também pedia 0 nome dos respondentes por questões organizacionais. A segunda pergunta trata acerca da 
experiência dos alunos em relação à língua alemã, uma vez que pergunta se eles já estudaram esse idioma em outra instituição, além do CEL:

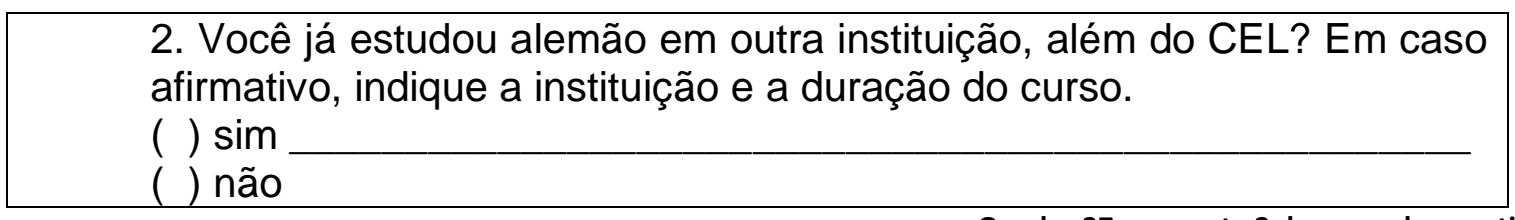

Quadro 27: pergunta 2 do segundo questionário

Nesta pergunta, todos os respondentes participantes da pesquisa assinalaram que nunca haviam estudado alemão em outra instituição, a não ser o próprio CEL.

Ainda sobre a experiência dos alunos com LE, a pergunta 3 questionava os respondentes em relação aos seus conhecimentos em outras línguas:

3. Além do alemão, em quais outras línguas você possui algum tipo de conhecimento? (você pode assinalar mais de uma alternativa)
( ) inglês
( ) espanhol
( ) francês
( ) italiano
( ) outros:

Quadro 28: pergunta 3 do segundo questionário

As respostas obtidas demonstram que todos os respondentes afirmam possuir conhecimentos em inglês e, grande parte deles, também em espanhol assim como se verifica na tabela abaixo:

\begin{tabular}{|l|c|}
\hline \multicolumn{1}{|c|}{ Idioma } & Número de respostas \\
\hline Inglês & 7 \\
\hline Espanhol & 4 \\
\hline Francês & Zero \\
\hline Italiano & Zero \\
\hline Outros & 1 \\
\hline
\end{tabular}

Tabela 7: respostas da pergunta 3 do segundo questionário

O respondente que marcou a opção "outros" afirmou em sua resposta possuir conhecimentos de russo em nível básico.

Ainda tratando sobre a experiência dos alunos acerca do seu aprendizado de LE, a pergunta 4 questiona se os respondentes já frequentaram aulas de algum idioma em outra instituição de ensino: 


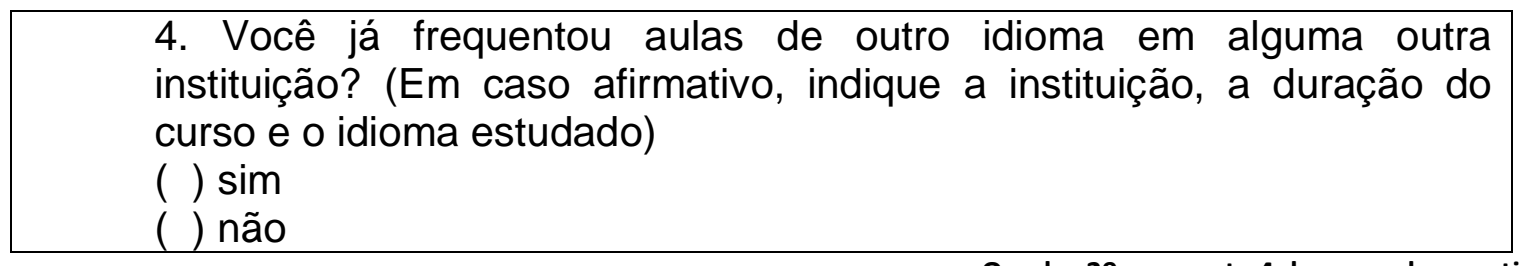

Quadro 29: pergunta 4 do segundo questionário

Entre os sete respondentes participantes desta etapa do questionário, três assinalaram a opção "não" e quatro assinalaram a opção "sim". Como a pergunta pedia para que os alunos indicassem a instituição e o tempo de curso, dois alunos informaram que haviam feito cursos em outros CEL da região, um deles frequentou aulas de inglês e o outro, de espanhol. Um dos respondentes não informou o nome da instituição, mas respondeu que fez inglês por um ano e, por fim, outro respondente afirma ter frequentado aulas de inglês por um ano em uma franquia de escolas de idiomas que se chama Centro Britânico.

A pergunta 5 investiga como os alunos ficaram sabendo que havia um curso de alemão no CEL no qual eles estudavam no momento da pesquisa:

\section{Como você ficou sabendo do curso de alemão no CEL?}

Quadro 30: pergunta 5 do segundo questionário

Para esta pergunta, as respostas foram bem diversas:

- A1: Estava interessado há alguns anos na língua e por meio da instituição onde estudava obtive a oportunidade.

- A2: Como já estudava espanhol no CEL, informaram as turmas nas salas que abririam turmas de alemão (o mesmo aconteceu com o espanhol, porém, fui informada onde eu fazia o ensino médio)

- A5: Fiquei sabendo pela escola. Tinham folhetos falando do curso.

- A7: Amigo!

- A10: Através de um aviso de outro CEL (de Franco da Rocha)

- A11: Através da antiga escola onde eu estudava, em que eles nos avisaram do curso, e eu fui conhecer.

- A12: No próprio CEL, em que já fiz espanhol, porém descobri a possibilidade dos cursos no CEL, através de divulgações na escola regular.

A pergunta 6 está diretamente relaciona à cinco e pede para que os alunos expliquem os motivos que os levaram a se inscrever no curso:

6. Por que você decidiu se inscrever para o curso? 
Neste caso e, assim como ocorreu na pergunta anterior, os motivos apontados são de diversas ordens:

- A1: Por interesse e pensamento do benefício da língua

- A2: Porque sempre gostei de idiomas e acho o alemão uma língua muito interessante.

- A5: Porque achei interessante falar outra língua (alemão)

- A7: Porque já estava a procura e queria muito fazer o curso.

- A10: Por achar a língua interessante

- A11: Por curiosidade, por gostar da língua

- A12: De início devido a curiosidade de um idioma que parecia muito abstrato como também a oportunidade de ser gratuito.

\subsubsection{Segunda parte do segundo questionário}

A segunda parte deste questionário é constituída por 12 perguntas e foi intitulada como "autonomia e estudo em casa". Nessa parte, os alunos responderam questões relacionadas não apenas à maneira como o LD é usado para seus estudos, mas também acerca de aspectos relacionados ao estudo fora da aula de alemão.

Nesse sentido, as perguntas 7, 8 e 9 formam o primeiro bloco dessa segunda parte, uma vez que tratam sobre o fato dos alunos terem ou não uma cópia do LD para uso próprio.

A questão 7 trata de forma objetiva sobre a quantidade de respondentes que possuíam uma cópia do LD utilizado em aula:

7. Você possuí uma cópia do livro didático (Kursbuch e Arbeitsbuch) em casa? (você pode assinalar mais de uma opção)

( ) sim, o Kursbuch original

( ) sim, o Kursbuch em pdf

( ) sim, o Kursbuch impresso

( ) sim, o Arbeitsbuch original

( ) sim, o Arbeitsbuch em pdf

( ) sim, o Arbeitsbuch original

( ) sim, o Arbeitsbuch impresso

( ) não, não possuo os livros

Quadro 31: pergunta 7 do segundo questionário

Para essa pergunta, cada um dos respondentes escolheu as seguintes opções: 


\begin{tabular}{|c|l|}
\hline Respondente & \multicolumn{1}{|c|}{ Opções escolhidas } \\
\hline A1 & Não, não possuo os livros. \\
\hline A2 & Não, não possuo os livros. \\
\hline A5 & Não, não possuo os livros. \\
\hline A7 & Sim, o Kursbuch em PDF/ sim, o \\
& Kursbuch impresso/ sim, o \\
& Arbeitsbuch em PDF/ sim, o \\
& Arbeitsbuch impresso. \\
\hline A10 & Sim, o Arbeitsbuch em PDF \\
\hline A11 & Sim, o Kursbuch impresso/ Sim, o \\
& Arbeitsbuch impresso \\
\hline A12 & Sim, o Kursbuch em PDF/ sim, O \\
& Arbeitsbuch em PDF \\
\hline
\end{tabular}

Tabela 8: respostas da pergunta 7 do segundo questionário

Quanto às respostas fornecidas, vale ressaltar que chama a atenção ao fato de três alunos afirmarem não possuir cópias do LD, já que quatro outros respondentes afirmam possuir cópias impressas e em PDF.

Seguindo essa investigação, a questão 8 complementa a informação obtida na questão sete e permite analisar possíveis divergências no discurso dos alunos em relação ao fato de ter ou não o LD:

8. Em uma escala de 1 a 6 em que 1 representa "pouca importância" e 6 representa "muita importância", qual é, na sua opinião a importância de se ter uma cópia do livro didático em casa.

Pouca importância (1) (2) (3) (4) (5) (6) Muita importância Quadro 32: pergunta 8 do segundo questionário

Para esta questão, a escolha dos respondentes foi:

\begin{tabular}{|c|c|}
\hline Respondente & Opção escolhida \\
\hline A1 & 6 \\
\hline A2 & 6 \\
\hline A5 & 4 \\
\hline A7 & 6 \\
\hline A10 & 4 \\
\hline
\end{tabular}




\begin{tabular}{|l|l|}
\hline A11 & 6 \\
\hline A12 & 6 \\
\hline
\end{tabular}

Tabela 9: respostas da pergunta 8 do segundo questionário

A partir das opções assinaladas pelos respondentes, é possível verificar que todos atribuem grande importância ao fato de ter uma cópia do LD. Mesmo os respondentes que afirmaram não possuir o LD marcaram a opção "6", que representa "muita importância" na escala fornecida no questionário. O respondente A5, que também afirma não possuir cópias do LD, atribuiu o valor "4" na escala apresentada, mostrando que esse respondente também reconhece a importância de se ter o LD, mesmo esse não sendo o seu caso.

Finalizando esse bloco que trata acerca do fato de ter ou não o LD em casa, a pergunta 9 pede para que os respondentes expliquem a sua opinião sobre a questão oito:

\section{Procure explicar a sua opinião sobre a questão 8:}

Quadro 33: pergunta 9 do segundo questionário

As respostas fornecidas pelos respondentes foram as seguintes:

- A1: Creio que um auxilio didático dentro de casa nos faz mais capazes de aprender

- A2: O livro supriria a necessidade de praticar o que foi passado em sala

- A5: Eu não tenho mas eu acho importante pois nele dá para tirar dúvidas, fazer atividades etc

- A7: Tem importância para as lições de casa e pra sempre estudar e fazer os exercícios

- A10: Considero importante, mas não obrigatório, pois o livro tem uma metodologia de ensino que pode ser super aproveitada pelo professor

- A11: Os livros são materiais de apoio, ou seja, somente as 4 horas, as quais passamos no curso não são suficientes, fazendo com que seja necessário nos aprofundarmos no assunto que tivemos no curso, revisarmos, fazer os exercícios, tudo para favorecer uma melhor aprendizagem

- A12: Por ser uma língua não muito falada, ainda mais no Brasil, o livro didático parece ser a bussola essencial para nos guiar no aprendizado do alemão.

As questões 10, 11 e 12, por sua vez, trabalham mais uma vez em bloco e tratam sobre a rotina de estudos em casa dos alunos. A pergunta dez questiona se os alunos costumam ou não estudar em casa:

10. Você costuma estudar alemão em sua casa com frequência?

( ) $\operatorname{sim}$

( ) não 
Apenas o respondente A12 marcou "não" como opção, os demais afirmaram que costumam estudar alemão em suas casas.

$\mathrm{Na}$ questão 11, os alunos são questionados sobre a quantidade de tempo reservada para o estudo em casa:

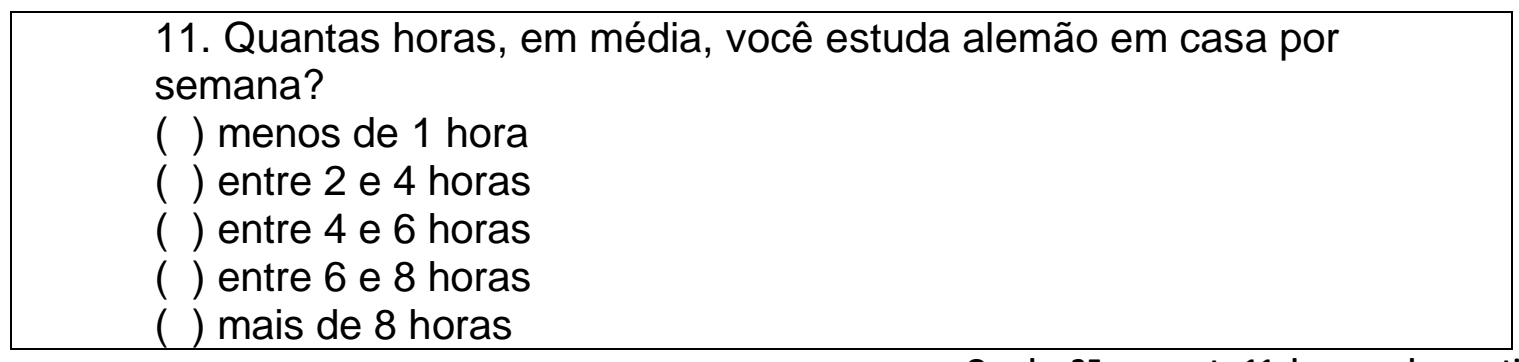

Quadro 35: pergunta 11 do segundo questionário

As respostas fornecidas por cada respondente foram:

\begin{tabular}{|c|l|}
\hline Respondente & Opção escolhida \\
\hline A1 & Menos de 1 hora \\
\hline A2 & Entre 4 e 6 horas \\
\hline A5 & Entre 2 e 4 horas \\
\hline A7 & Entre 2 e 4 horas \\
\hline A10 & Menos de 1 hora \\
\hline A11 & Menos de 1 hora \\
\hline A12 & Menos de 1 hora \\
\hline
\end{tabular}

Tabela 10: respostas da pergunta 11 do segundo questionário

Graficamente representados, os dados da tabela poderiam ser dispostos da seguinte maneira:

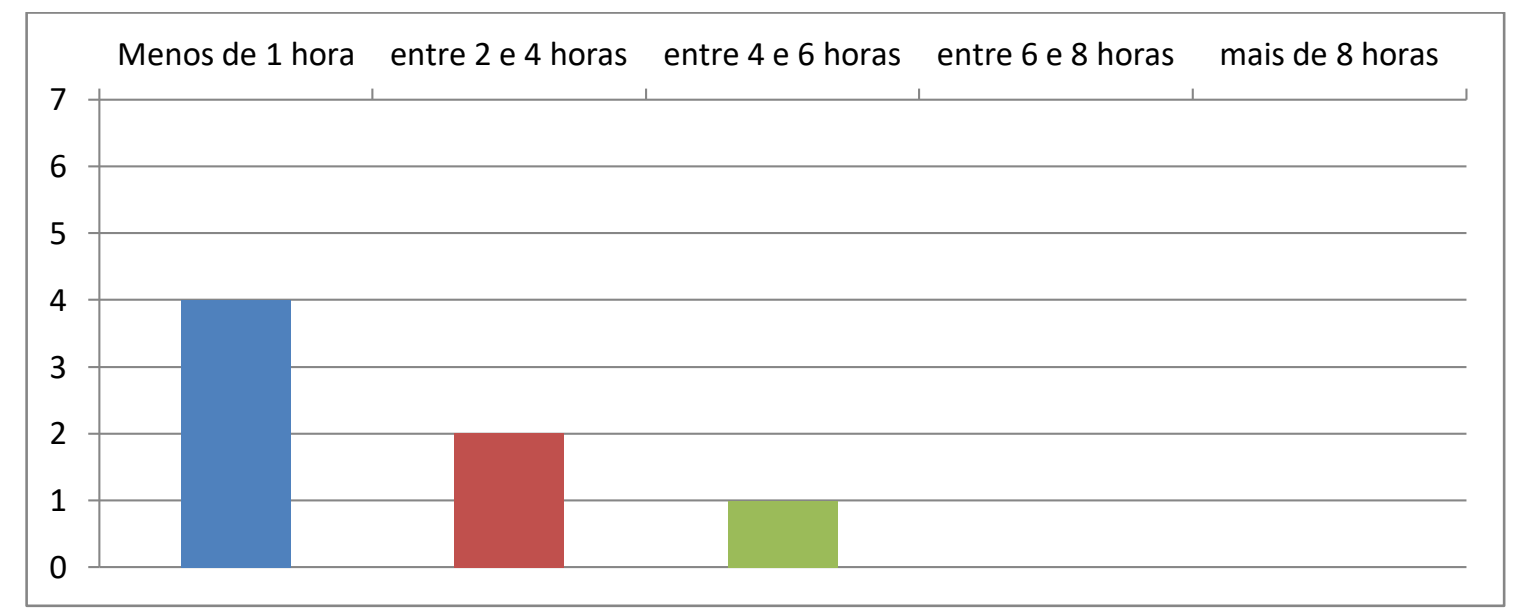


A pergunta 12 pede para que os alunos forneçam dados concretos acerca de sua rotina de estudos em casa:

12. Como você estuda em casa? Procure dar exemplos concretos sobre a sua rotina de estudos em relação ao alemão.

Quadro 36: pergunta 12 do segundo questionário

Neste caso, as respostas dos respondentes foram as seguintes:

- A1: Não obtenho maneiras específicas, pois gosto de um estudo diferenciado, mas sempre estou ouvindo músicas, visualizando sites e vendo vídeos.

- A2: Eu procuro artigos em alemão, filmes ou vídeos em alemão, mas prefiro ouvir músicas e procurar a tradução ou significado da letra (porém, me sinto mais confortável em fazer exercícios para casa que foram passados em aula, pois consigo relembrar e aprender melhor o conteúdo).

- A5: Eu assisto vídeos aula, releio o conteúdo dado nas aulas, com músicas etc.

- A7: Vendo algumas vídeo aulas, falando, escrevendo, fazendo exercícios

- A10: Utilizo de tópicos, como os que tenho dúvidas, ou os que mais gosto, então procuro vídeos e conversas em fóruns sobre

- A11: Procuro aplicativos que ajudem a revisar assuntos tratados no curso, procuro sites especializados na língua alemã, vejo as traduções das músicas alemãs, assisto vídeo aulas e reviso a matéria já estudada

- A12: Procuro vídeos, ou acabo pesquisando questões gramaticais. Não sei ainda a melhor forma para se aprender vocabulário. Realizo ou reviso exercícios que tenho em meu caderno e tento aprender novas palavras ouvindo-as.

Vale notar que, mesmo os alunos que afirmaram ter cópias do LD na pergunta sete, não citam esse dispositivo ao descrever a sua rotina de estudo em casa. Todos eles, por outro lado, citam aplicativos, vídeos da internet e músicas. De certa forma, apresenta-se uma possível contradição, uma vez que, mesmo afirmando que é importante ter uma cópia do LD, como descrito na questão seis, os alunos não se apropriam desse dispositivo para estudar em casa.

As respostas obtidas na questão doze entram também em contradição com o que foi dito na questão 13 , que perguntava aos respondentes os materiais utilizados por eles para estudar em casa:

13. Quais dos materiais abaixo você utiliza para estudar em casa?

( ) o livro didático

( ) dicionários (impressos ou online)

( ) listas de palavras

( ) aplicativos de celular

( ) outros livros didáticos diferentes do usado em aula* (assinalando essa alternativa, responda a questão 14)

( ) outros: 
As respostas fornecidas pelos respondentes foram as seguintes:

\begin{tabular}{|c|c|}
\hline Respondente & Opções escolhidas \\
\hline A1 & $\begin{array}{l}\text { Listas de palavras/ aplicativos de } \\
\text { celular/ outros: sites, youtube }\end{array}$ \\
\hline A2 & $\begin{array}{l}\text { Dicionários (impressos ou online)/ } \\
\text { aplicativos de celular/ outros: Musicas } \\
\text { e textos da internet }\end{array}$ \\
\hline A5 & $\begin{array}{l}\text { Dicionários (impressos ou online)/ } \\
\text { listas de palavras/ aplicativos de } \\
\text { celular. }\end{array}$ \\
\hline A7 & $\begin{array}{l}\text { O livro didático/ dicionários } \\
\text { (impressos ou online)/ aplicativos de } \\
\text { celular }\end{array}$ \\
\hline A10 & $\begin{array}{l}\text { O livro didático./ dicionários } \\
\text { (impressos ou online)/ listas de } \\
\text { palavras/ aplicativos de celular }\end{array}$ \\
\hline A11 & $\begin{array}{l}\text { O livro didático/ Dicionários } \\
\text { (impressos e online)/ listas de } \\
\text { palavras/ Aplicativos de celular }\end{array}$ \\
\hline A12 & $\begin{array}{l}\text { Dicionários (impressos ou online)/ } \\
\text { aplicativos de celular/ outros: filmes, } \\
\text { séries, desenhos... }\end{array}$ \\
\hline
\end{tabular}

Tabela 11: respostas da pergunta 13 do segundo questionário

Como esperado, todos os respondentes assinalaram opções ligadas a dispositivos tecnológicos, porém, diferente do que ocorreu na pergunta doze, três respondentes também afirmaram utilizar o LD para estudar em suas casas.

A pergunta 14 deveria ser respondida apenas pelos respondentes que assinalassem a alternativa "outros livros didáticos diferentes dos usados em aula" na pergunta 13:

14. Quais são os outros livros didático que você costuma utilizar para estudar alemão em casa? 
Como nenhum respondente escolheu a opção citada na pergunta treze, nenhum deles respondeu a esta pergunta, exceto o respondente A11 que escreveu: "basicamente só dicionários mesmo, guias de conversação, entre outros". Neste caso, provavelmente a resposta foi dada devido à distração do respondente ao ler a pergunta 13.

A pergunta 15 pedia para que os alunos enumerassem os materiais citados por eles na pergunta 13 de acordo com o grau de importância atribuído a esses materiais:

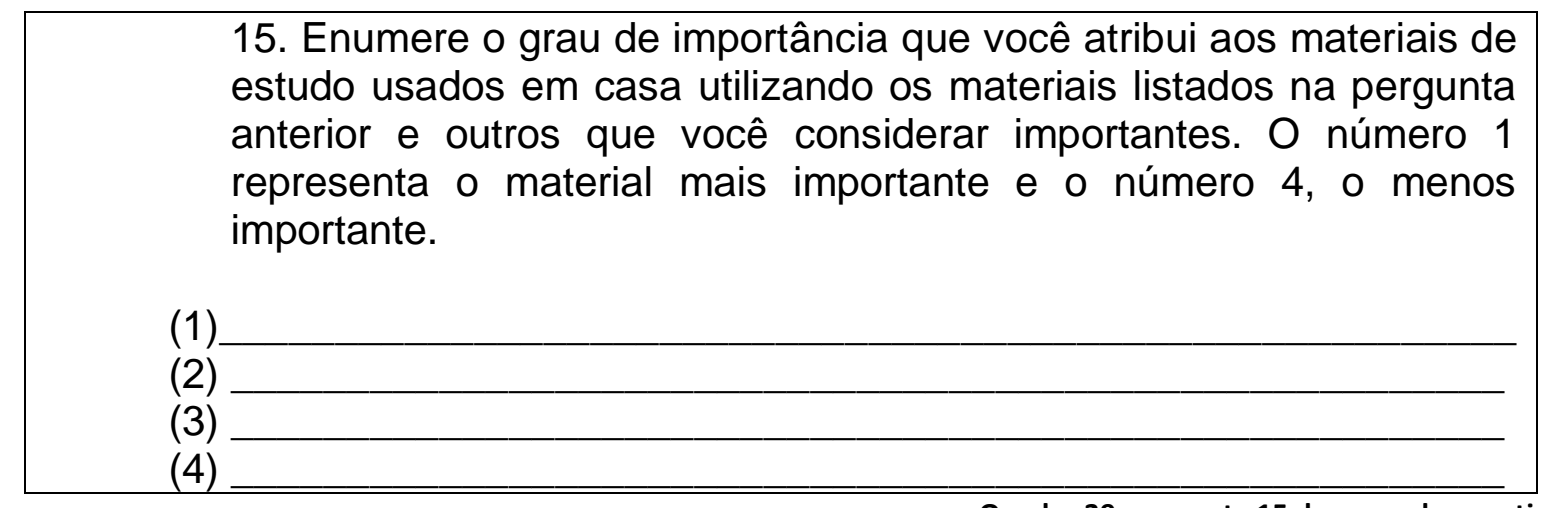

Quadro 39: pergunta 15 do segundo questionário

Para esta questão, os respondentes elencaram os materiais na seguinte ordem:

- A1: 1. Listas de palavras/2. Aplicativos/3. Sites/4. Vídeos

- A2: 1. Livro didático de exercícios/2. Dicionário/3. Aplicativos de celular/ 4. Conteúdo da internet

- A5: 1. Aplicativos de celular/2. Dicionários/3. Listas de palavras/4. Não escreveu nada

- A7: 1. O livro didático/2. Dicionário/3. Aplicativo/4. Não escreveu nada

- A10: 1. Listas de palavras./2. Dicionários/3. Aplicativos/4. Livro didático

- A11: (1) Guias de conversação/ (2) Dicionários

- A12: 1. Listas de palavras/2. Aplicativos/ 3. Vídeos (Filmes, séries, desenhos)/ 4. Dicionários.

Cabe ressaltar que o LD foi listado apenas por três respondentes - A2, A7 e A10 - e, entre eles, apenas dois elencaram o dispositivo como sendo o material de maior relevância para estudar em casa.

A pergunta 16 apresentou uma escala para que os alunos avaliassem o seu grau de autonomia para estudar alemão em casa: 
16. Como você avalia o seu grau de autonomia para estudar alemão em casa? 1 representa "pouco autônomo" e 6 representa "muito autônomo".

Pouco autônomo (1) (2) (3) (4) (5) (6) muito autônomo Quadro 40: pergunta 16 do segundo questionário

As respostas fornecidas pelos respondentes foram:

\begin{tabular}{|c|c|}
\hline Respondente & Opção escolhida \\
\hline A1 & 4 \\
\hline A2 & 3 \\
\hline A5 & 2 \\
\hline A7 & 5 \\
\hline A10 & 3 \\
\hline A11 & 2 \\
\hline A12 & 2 \\
\hline
\end{tabular}

Tabela 12: respostas da pergunta 16 do segundo questionário

Nesta pergunta, as respostas fornecidas pelos respondentes foram bem diversas. Ao mesmo tempo em que há alunos que se afirmam como sendo autônomos no estudo de alemão em casa, outros escolheram um valor bem baixo de acordo com a escala fornecida na própria questão.

A fim de verificar o que os alunos entendem por autonomia, a pergunta 17 pede para que eles expressem a sua opinião sobre o que significa ser autônomo:

17. Na sua opinião, o que significa ser autônomo no estudo de uma língua estrangeira?

Quadro 41: pergunta 17 do segundo questionário

As respostas fornecidas para essa pergunta foram as seguintes:

- A1:

Creio que significa uma confiança e curiosidade para estudar, pois acredito que esses são os pilares de um aprendizado com sucesso. Sem contar que um aluno confiante e curioso sempre terá de certa forma mesmo de forma omissa uma autoeducação.

- A2:

Ser autônomo é conseguir mostrar um cronograma de atividades para estudar, ter disciplina e não deixar de reservar um tempo para estudar. $\mathrm{O}$ autônomo não necessita de uma tarefa específica (passada pelo professor) para estudo, ele consegue por si identificar o que precisa estudar e como fazê-lo. 
- A5:

Na minha opinião é que você domine a língua, que saiba bastante coisas da língua.

- A7:

Significa estudar porque eu quero, por conta própria não porque estão mandando, mas estudar por gostar.

- A10:

Não depender de livros e dicionários, mas sim, saber equilibrar estes com o contato com falantes da língua e sua cultura

- A11:

Procurar ser curioso sobre a língua, compreender que é necessário esforço para conseguir prosseguir, revisar sempre que possível, e nunca desistir.

- A12:

Não só desejar estudar, como também saber como realizar tal atitude, ou seja, ser autônomo é saber seguir os melhores caminhos para estudar.

Por fim, a pergunta 18, pedia para que os alunos completassem duas afirmações:

18. Complete as frases (grife o conector utilizado):

Estudar em casa é importante pois/ porque:

Estudar em casa seria mais fácil se/ quando:

Quadro 42: pergunta 18 do segundo questionário

Para esta questão, as respostas fornecidas foram:

- $\mathrm{A} 1$

POIS conhecimento é a base de um futuro melhor./ SE tivéssemos áudios passados pela instituição.

- $\mathrm{A} 2$

PORQUE é onde vai se firmar o que foi passado em aula./ SE houvesse ferramentas mais abrangentes e confiáveis (como o livro didático e o dicionário físico).

- A5

PORQUE ajuda nos temas que você não conseguiu aprender direito, a fixar o conteúdo das aulas./ SE tivesse mais recursos para o nosso estudo como palestras, livros e dicionários.

- $\mathrm{A} 7$

POIS se queremos falar temos que estudar, a força de vontade é tudo./ SE tivesse a ajuda de alguém que fale alemão. 
- $\mathrm{A} 10$

POIS assim podemos prolongar as informações aprendidas durante as aulas/ QUANDO não tivéssemos outras responsabilidades no caminho (cuidar de animais, limpar a casa, fazer comida, ter momentos de lazer, etc).

- $\mathrm{A} 11$

Estudar em casa é importante pois favorece no auxilio da evolução que o aluno necessita/ Estudar em casa seria mais fácil se tivéssemos uma monitoria, caso precisássemos.

- $\mathrm{A} 12$

POIS além de servir como uma revisão parece ser um contato mais concreto, existe mais assimilação./ SE eu soubesse exatamente um método adequado, principalmente para adquirir vocabulário. 


\section{Análise dos dados}

Este capítulo tem como objetivo analisar os dados apresentados no capítulo anterior de modo a expor alguns aspectos relacionados à forma como os alunos se referem ao LD em seus estudos de alemão além das necessidades decorrentes do contato entre esses alunos e o LD utilizado durante as aulas.

Como há uma grande quantidade de dados, eles serão tratados muitas vezes através do processo de triangulação de dados (cf. AGUADO, 2015). Desse modo, dados obtidos através dos questionários poderão ser reforçados ou refutados a partir da análise de dados coletados nas estações de trabalho que foram realizadas ao longo das etapas de coleta.

Para fins de análise, após selecionar os diversos aspectos possíveis de serem analisados, optou-se por desenvolver a análise levando em consideração os três tipos de necessidades descritos por Weissenberg (2012): as necessidades subjetivas, as necessidades objetivas e as necessidades processuais. Contudo, levando em conta o objetivo deste trabalho, a análise incide, sobretudo, sobre as necessidades subjetivas e processuais. Cabe ressaltar que, apesar da análise incidir sobre as necessidades subjetivas e processuais, as necessidades objetivas serão abordadas, ainda que brevemente, levando em conta que elas se relacionam entre si de modo que não é possível excluir totalmente esse tipo de necessidade.

Primeiramente, retomarei brevemente o conceito de necessidades objetivas e tratarei sobre como o conceito se aplica aos dados da pesquisa. Em seguida, abordarei as necessidades subjetivas, que têm como foco a perspectiva dos próprios alunos acerca de suas necessidades com relação ao LD. Nesta parte, serão abordados aspectos inerentes às relações estabelecidas entre eles e esse dispositivo no que concerne a questões de apropriação e uso do LD para o processo de aprendizagem de alemão. Além disso, também serão analisadas possíveis opiniões pró e contra o uso desse material na visão dos alunos.

Por fim, serão abordados aspectos das necessidades processuais presentes nos dados de modo a expor como as necessidades dos alunos são percebidas pelo professor durante o processo de ensino-aprendizagem. 


\subsection{Necessidades objetivas}

Assim como descrito na seção 2.1.2. - Tipos de necessidades - Weissenberg descreve três tipos de necessidades que são analisadas a partir de perspectivas diferentes (cf. WEISSENBERG, 2012). Nesse sentido, o primeiro tipo de necessidade descrita pelo autor é justamente a que ele descreve como necessidades objetivas ou orientadas pelo produto.

Esse tipo de necessidade está diretamente ligado a fatores que extrapolam os limites da sala de aula e têm relação com aspectos burocráticos e legais que envolvem os cursos e o seu funcionamento. Nesse sentido, lembrando do contexto descrito na seção 3.1.2. - Contexto concreto da pesquisa - surgem alguns aspectos que evocam esse tipo de necessidade. Dito de outra maneira, as necessidades objetivas são aquelas que se relacionam diretamente com aspectos regimentais que direcionam o funcionamento dos cursos. Portanto, esse tipo de necessidade abrange aspectos legislativos e reguladores no sentido de que representam fatores externos à vontade dos professores ou dos alunos de determinada instituição.

Dessa forma, toda a legislação que regulamenta o funcionamento dos CEL e que especifica, por exemplo, a quantidade mínima e máxima de alunos por turma, a quantidade de aulas por semestre, carga horária e critérios para a abertura de turmas é diretamente relacionada com as necessidades objetivas. Além disso, de forma menos abrangente, aspectos que dependem de outras instâncias e que não podem ser discutidas diretamente também fazem parte destas necessidades, assim como a escolha do LD para o contexto dos CEL.

É preciso deixar claro que as necessidades objetivas não aparecem de forma explícita nos dados coletados uma vez que não é o objetivo principal desse trabalho analisar esse tipo de necessidade. Contudo, não se pode ignorar o fato de que os alunos e o LD estão inseridos em um contexto educacional que, por sua vez, envolve aspectos que remetem a tais necessidades.

Nesse sentido, é preciso retomar o fato de que o LD utilizado nas aulas da turma investigada é escolhido e fornecido aos CEL pelo Instituto Goethe que possui um acordo de cooperação junto à Secretaria de Educação do Estado de São Paulo. Com isso, além de ceder material didático para os CEL - incluindo os volumes do 
LD - o Instituto também oferece orientações técnicas periódicas para os professores de alemão regularmente inscritos em suas Diretorias de Ensino.

Lembrando do contexto do CEL em relação ao $L D$ e a forma como o dispositivo chega à escola através da doação do Instituto Goethe e todas as consequências decorrentes disto, percebe-se claramente a presença das necessidades subjetivas nesse contexto, já que a escolha e a demanda dos LD que chegam às escolas estão diretamente ligadas a fatores que não dependem exclusivamente dos alunos. Vale ressaltar, ainda, que o não oferecimento de LD em larga escala para os alunos de alemão da rede pública se deva ao fato de que o idioma não é contemplado no PNLD assim como o inglês e o espanhol e que a verba para a compra desse material parte do próprio Instituto Goethe.

Nos dois idiomas citados no parágrafo anterior, todos os alunos recebem um exemplar de um LD no início do curso e, ademais, todos os anos as escolas recebem exemplares de editoras diversas oferecendo seus livros desses respectivos idiomas para análise e possível adoção para os cursos. Esse fato corrobora com a visão de que a oferta de LD para estes dois idiomas oferecidos no CEL é mais ampla do que ocorre no caso do alemão.

Sobre o fato dos livros não serem retirados da escola, os alunos participantes da pesquisa afirmam em determinado momento que seria interessante se todos tivessem um exemplar (este aspecto será tratado nas necessidades subjetivas), porém, eles não se manifestam claramente contra essa prática de ter que deixar os livros na escola de modo que tal situação passa a ser vista como algo natural que rege o funcionamento do curso de alemão no CEL para eles. Neste caso, há a intersecção das necessidades objetivas com as subjetivas, uma vez que, por um lado, existe o fator do LD que precisa ficar na escola para uso exclusivo durante as aulas e, por outro, o fator dos alunos que não estão totalmente de acordo com essa situação, mas que não expressam maneiras de mudar essa situação.

Sempre no começo do curso - na escola em que a pesquisa foi feita - é oferecido aos alunos a oportunidade de fazer cópias de algumas partes, tanto do livro de curso, quanto do livro de atividades para que eles tenham esse material disponível para estudar não apenas nas aulas, mas também em casa. Contudo, fica 
a cargo do próprio aluno optar por fazer ou não uma cópia ou adquirir um exemplar do LD.

\subsubsection{A organização do curso e o uso do LD}

Na seção 2.3.3. deste trabalho, que tratou sobre a estrutura de funcionamento dos cursos do CEL, foi apresentada a carga horária e a macro-organização dos cursos dos centros. Tais disposições dependem em grande medida de legislação específica que atende aos CEL e que abordam, inclusive, a quantidade de semestres e aulas que cada estágio deve ter. No entanto, o que não consta da legislação mas ocorre com frequência, é justamente o fato de que o LD - na ausência de um currículo específico - passa a constituir o elemento organizador da progressão do curso. O curso de alemão tem duração de três anos, nos quais é oferecido aos alunos a oportunidade de estudar - a priori - até o final do nível A2.

Apesar de parecer um simples elemento organizacional, cabe averiguar que não há nada na legislação que estabeleça que os alunos possam estudar até determinado nível. Esta divisão é fortemente guiada pelo LD, já que nos CEL há disponíveis os livros de nível A1 e A2. Em outras palavras, a presença do LD faz com que a organização do curso em relação aos conteúdos e ao nivelamento sejam controlados. O LD passa, portanto, a ser o elemento que norteia em certa medida o funcionamento do curso de maneira geral.

O fato dos alunos disporem dos livros de nível A1 e A2 não representa em si a garantia de que esse nível será alcançado pelo aluno, uma vez que a aprendizagem depende de vários fatores e não exclusivamente do LD. Além disso, levando em conta que cada turma possui um ritmo específico de aprendizagem e que as unidades de um LD não avançam sempre na mesma velocidade, pode ocorrer que em uma determinada turma os alunos não consigam chegar ao final de todas as unidades do livro de nível A2 ao final dos três anos de curso.

Também não se pode ignorar o fato de que os alunos da rede pública não podem ser reprovados por suas notas devido ao programa de progressão continuada do Estado de São Paulo de modo que, mesmo com notas abaixo da média, os alunos têm o direito de avançar para uma outra série - ou estágio no caso 
dos CEL - caso tenham frequência satisfatória (acima de $80 \%$ de um total de 80 aulas no semestre). A partir disso, um aluno nessas condições, mesmo com um rendimento acadêmico considerado insatisfatório, pode concluir o curso de alemão sem que ele tenha realmente alcançado o nível de conhecimento proposto pelo LD. Apesar disso, ao organizar os cursos, a orientação dada pela escola que abrigou a pesquisa é que cada nível (três módulos) seja dividido de modo que cada LD dure pelo menos um ano e meio para coincidir com a duração desses módulos.

Assim, o que se nota é que o LD, além de ser um dispositivo de apoio para o estudo dos alunos, atua como um elemento norteador da própria organização do curso e a sua duração chega a ser confundida com a duração do próprio curso. durante os períodos de planejamento, que ocorrem no início de todo semestre, existe a necessidade de fazer um replanejamento, tanto no CEL, quanto no ensino regular. Nessa oportunidade, a orientação recebida é que novos conteúdos sejam escolhidos para as aulas, porém, esses conteúdos não se relacionam com dinâmicas e outras atividades que devem ser inseridas ao longo do semestre. Contudo, neste caso, mesmo que de forma mascarada, o LD ainda atua como elemento norteador já que tais atividades são escolhidas levando em conta os conteúdos que já haviam sido escolhidos para a aula previamente através do LD.

Ainda sobre esses períodos de planejamento ou replanejamento, a própria coordenação pedagógica se apoia muitas vezes em aspectos do próprio LD para dar instruções aos professores. Cabe, no entanto, averiguar o que essas escolhas que se relacionam com aspectos das necessidades objetivas acarretam para o contexto das aulas como um todo e como os alunos se posicionam frente a isso.

\subsection{Necessidades subjetivas}

Necessidades subjetivas estão relacionadas com as necessidades expressas pelos próprios aprendizes (cf. WEISSENBERG, 2012) e, nesse sentido, aparecem em grande quantidade nos dados obtidos. Contudo, nas próximas seções os dados elencados mostrarão que nem sempre os alunos têm destreza suficiente para descrever as suas necessidades, de forma que isso precisa ser averiguado 
analisando possíveis divergências nos discursos e a falta de reflexão nas respostas fornecidas por eles.

\subsubsection{A presença do LD e a importância atribuída a ele}

O LD, não apenas no contexto específico do CEL, costuma permear fortemente as práticas pedagógicas desenvolvidas nos cursos de LE (cf. BIMMEL et al., 2011). Em lugares onde não há um currículo específico para o ensino de LE como é o caso do Brasil, que prevê apenas diretrizes nas OCEM e nos PCNs - o LD passa a desempenhar essa função, de modo a operacionalizar o currículo, determinar os objetivos e definir os conteúdos que serão trabalhados em aula (NEUNER, 1999, p. 160 apud UPHOFF, 2009, p. 61). Vale ressaltar que já há no Brasil lugares e instituições que adotam um currículo, como é o caso das escolas alemãs $^{27}$ e das escolas que preparam para o Deutsches Sprachdiplom. Esse currículo específico se intitula: Rahmenplan "Deutsch als Fremdsprache" für das Auslandsschulwesen.

Outro fator a ser observado e que elevaria a importância do dispositivo para uso específico no contexto brasileiro de ensino- aprendizagem de alemão relacionase à distância entre Brasil e Alemanha. Assim como aponta Bohunovsky (2011) o fato dos dois países citados serem geograficamente distantes diminui as chances de um aluno visitar o país da língua alvo com facilidade. Desse modo, observando essa condição do ensino de alemão no Brasil e aplicando-o ao contexto específico do CEL, nota-se realmente que o LD, além de um dispositivo pedagógico usado para fins didáticos, adquire nesta situação a função de apresentar o país da língua que está sendo estudada e passaria, portanto, a agir como uma espécie de "cartão postal" (BOLOGNINI, 1991) do país ou países nos quais a língua alvo é falada já que o dispositivo seria um dos únicos intermediadores entre os alunos e aqueles países, ainda de acordo com Bohunovsky (2011).

27

http://www.bva.bund.de/DE/Organisation/Abteilungen/Abteilung ZfA/Auslandsschularbeit/DSD/Rahmenplan DaF/DaF-Rahmenplan.pdf? blob=publicationFile\&v=1 (consultado em 15/06/ 2018) 
Assim, levando em consideração um contexto no qual a prática pedagógica do professor e a organização do curso estão tão vinculadas ao uso do LD e, ainda, pensando nos usos e funções atribuídas normalmente a esse dispositivo, cabe averiguar a posição dos alunos em relação a ele uma vez que eles estão em contato com esse material durante o seu processo de aprendizagem de LE.

Contudo, o fato do LD adquirir importância para o contexto de ensino de LE, não significa necessariamente que os alunos reconheçam tal importância já que o uso desse dispositivo em muitas instituições - como é o caso do CEL - perpassa por uma série de questões ligadas às necessidades objetivas, como a não distribuição de um exemplar do dispositivo para cada aluno. Dessa forma, no contexto analisado, a presença do LD e as condições que a cercam são vistas com naturalidade, assim como foi descrito na seção anterior, que tratava acerca das necessidades objetivas.

Nesse sentido, a primeira informação levantada junto aos alunos quanto à importância atribuída ao LD por eles revela alguns fatos relevantes. Primeiro, ao notar que todos os respondentes escolheram um valor alto para descrever a importância do LD - assim como verificado na pergunta 7 do primeiro questionário -, pode-se encontrar ressonância no fato de que essa informação é resultado de anos de estudo nos quais o LD se configurou como elemento permeador da prática de ensino-aprendizagem de LE vivida por esses alunos, sobretudo no ensino de disciplinas do ensino regular, como é o caso da língua inglesa. Com isso, o fato de haver um LD no contexto de aprendizagem de alemão torna esse dispositivo importante, sem que seja necessário avaliar a real utilidade dele para o contexto específico. Em outras palavras, o LD é tido como importante pelos alunos devido ao fato de que ele sempre esteve presente na rotina escolar. Por isso, ao serem questionados acerca da importância desse dispositivo para as aulas de alemão, mesmo que de forma não consciente, os alunos tendem a escolher um valor elevado, uma vez que, caso não fosse importante, não existiriam motivos para se usar esse material em quase todas as aulas oferecidas na escola de forma geral.

Desse modo, nota-se uma divergência quanto à questão da importância atribuída ao LD pelos alunos no momento em que se verifica a disparidade de 
respostas obtidas quando eles foram questionados acerca da quantidade de tempo em que o dispositivo é utilizado durante as aulas.

Assim como foi apontado no capítulo anterior, grande parte dos alunos alega que menos de $50 \%$ do tempo da aula é utilizado com atividades do LD, de modo que surge o questionamento acerca da validade da importância que foi atribuída por eles a esse material.

Em outras palavras, um dispositivo que é pouco utilizado nas aulas não deveria - a priori - possuir um grau de importância tão elevado, no entanto, esse dado demonstra que a importância do LD está relacionada a um discurso já arraigado nos alunos e que diz respeito ao contexto amplo no qual eles estão inseridos que encara a presença do LD como sendo algo mais importante em detrimento de outros elementos que porventura possam ser utilizados nas aulas (cf. SOUZA, 1995). Além disso, a importância atribuída ao dispositivo vai, às vezes, além do aspecto relacionado com o processo de ensino-aprendizagem. As frases elencadas a seguir foram fornecidas como resposta para a pergunta 14 da primeira fase do questionário que perguntava se a aula de alemão ficaria melhor caso todos os alunos tivessem um exemplar do LD:

- Sim. Se todos os alunos tivessem um exemplar em mãos (onde o mesmo poderia ser levado para casa) o aproveitamento e aprendizagem das lições seria melhor. (respondente A2)

- Sim, melhora o desempenho do aluno e não precisa olhar o do colega para fazer as tarefas pedidas. (respondente A5)

- Sim, pois cada um com um exemplar fica melhor o aprendizado individual, podendo assim cada aluno tirar suas dúvidas sem ficar envergonhado. Muitas das vezes em que o livro é dividido alguns alunos ficam tímidos em apresentar suas dúvidas devido a sua dupla. (respondente A6)

- Não todos os alunos, mas tendo 2 pelo menos é bom porque existe uma atenção melhor principalmente os alunos que não tem mentes desenvolvidas. (respondente A7)

- Sim. Melhor em um sentido de que com exemplares, todos podem ter acesso ao auxilio provido pelo livro, além de poderem personalizar suas anotações. (respondente A10)

- Sim, quando todos possuem o mesmo material de apoio, fazendo com que todos participem e mantenha um certo nivelamento entre os alunos. (respondente $\mathrm{A} 11$ )

- Sim, pois ele adquire maior intimidade com o livro, podendo prestar mais atenção nos detalhes, por exemplo. (respondente A12) 
- Sim, no sentido de facilitar o entender da aula. O livro auxilia e reforça o conteúdo aprendido em sala. (respondente A14)

Exceto a resposta fornecida pelo indivíduo A7, que possui um teor muito vago, os demais respondentes mostraram com suas respostas que a presença do LD nas aulas é importante em diversos sentidos. Dessa forma, observa-se que essa importância vai desde aspectos relacionados com as anotações próprias - assim como descreve o respondente $A 11$-, até aspectos relacionados com o nivelamento dos alunos e o reforço de conteúdos, assim como mencionam os respondentes $A 11$ e A14, respectivamente.

A resposta fornecida, neste caso, pelo respondente A6 aponta que a presença do LD nas aulas é importante porque alguns alunos podem ficar envergonhados quando precisam dividir o material com outro. Neste caso, percebese claramente uma necessidade subjetiva já que o respondente, mesmo não utilizando um juízo de valor para afirmar que gosta ou não de dividir o LD durante a aula, deixa claro que esse compartilhamento pode não ser benéfico. Além disso, a resposta fornecida pelo respondente $A 7$ vai nesse mesmo sentido e aponta para o fato que a atenção é um fator decisivo para tratar sobre a presença do LD nas aulas já que ter que dividir o material com outro aluno pode acarretar na perda de foco de algum dos alunos que estão dividindo o material durante a aula.

A questão levantada pelo respondente A12 acerca de adquirir maior intimidade com o LD quando cada aluno possui um exemplar remonta a alguns aspectos que apareceram durante as estações e que corroboram com o fato de que os alunos do grupo analisado possuem pouca familiaridade com o LD uma vez que eles não foram capazes de identificar estruturas e seções do LD, assim como ocorreu na primeira pergunta da primeira estação da primeira etapa da coleta de dados que perguntava aos alunos sobre a estrutura do LD:

1- Observem o índice do Kursbuch da lição 17 até a 20 e tentem entender como o livro foi desenvolvido. Respondam as questões abaixo:

a. Como cada uma das lições se organiza? Existe alguma ordem?

b. A qual lição pertencem as páginas 29 a 32 ("Zum Schluss")?

c. Para que vocês acham que serve a página 5 ? 
Em relação a essa situação, Uphoff (2009) ao tratar sobre os discursos legitimadores do LD convencional, descreve que para alguns autores, como Dietrich (2008) e Rubdy (2003), as modalidades de ensino que utilizam materiais caseiros ou, ainda, que trabalham sem o uso de um LD são geralmente menosprezadas. Dessa forma, mesmo que de forma implícita, nota-se que o LD, no contexto analisado, adquire sim o status de dispositivo legitimador do curso de modo que os alunos, mesmo afirmando que este não é utilizado em grande parte da aula, ainda atribuem a ele um grau elevado de importância.

Assim como a importância atribuída ao LD, o grau de satisfação dos alunos em relação ao dispositivo também é alto. No entanto, quando questionados acerca dos motivos que fazem com que eles estejam satisfeitos, as respostas muitas vezes contradizem o que foi expresso pelo respondente anteriormente. Dessa forma, há respondentes que marcaram um alto índice de satisfação com o LD, mas que, por outro lado, ao explicar esse dado, elencam pontos negativos do dispositivo.

Os respondentes A5 e A7 fornecem respostas com o mesmo teor, já que não deixam claro qual é a sua opinião. $O$ aluno $A 5$ usa o critério de não entender alguma coisa para não gostar do livro. Dito de outra forma, o LD é satisfatório quando o aluno entende, quando isso não acontece, ele não fica satisfeito com o livro. Já o respondente A7 afirma que o livro é bom, no entanto, ele deixa claro - mesmo que de forma implícita - que há uma deficiência no dispositivo demonstrada a partir da frase "precisamos de mais exercícios específicos":

- A5 (grau de importância "4" / grau de satisfação "4") ${ }^{28}$

Para mim é 4 , pois tem vezes que não entendo um tema e fico um "pouco satisfeito".

- A7 (grau de importância "5" / grau de satisfação "4")

O livro é bom só que precisamos de mais exercícios específicos direção:

Os respondentes A2, A6 e A10 fornecem respostas que vão na mesma

- A2 (grau de importância "5"/ grau de satisfação "4")

O livro possui algumas lições que exigem um pouco mais de atenção que outras, porém, outras são bem explicadas ou possuem enunciados mais simples, fáceis de entender.

- A6 (grau de importância “5” / grau de satisfação “5”)

\footnotetext{
${ }^{28}$ Para este caso, o valor mais alto da escala era 6.
} 
O livro é bem ilustrativo e de fácil compreensão sempre nos apresenta a temática e no fim de cada unidade há uma pequena revisão do que aprendemos.

- A10 (grau de importância "5" / grau de satisfação "6")

O livro aborda de maneira prática o conteúdo demonstrado, além disso, - mesmo traz figuras que facilitam o entendimento, além de dicas e vocabulários úteis/ necessários.

- A11 (grau de importância "5" / grau de satisfação "5")

Quaisquer que for o tema e/ou atividade proposta pelo livro, possui uma forma de explicar tornando o aprendizado mais fácil, porém, não são todas as atividades de fácil entendimento, fazendo com que, as vezes, confunda o aluno, não apresentando a explicação clara para prosseguir com a atividade proposta.

Em relação ao afastamento no valor da escala e a não manifestação clara de críticas, nota-se que o aluno A11 nem ao menos escolheu um valor diferente para pontuar a sua crítica acerca do LD didático.

Aqui, nota-se que os alunos, por vezes, utilizam frases muito amplas para tentar explicar a sua opinião e que surgem alguns dados importantes sobre a forma como o dispositivo é encarado durante as aulas. Além disso, ao observar os valores escolhidos pelos alunos, percebe-se que, quando há uma crítica ao LD, os alunos tendem a se afastar apenas um grau do valor de importância na escala de satisfação. Esse pouco afastamento já sugere em si que há pouca disposição por parte dos respondentes em se posicionar e manifestar críticas de forma clara.

Por um lado, existem alunos como é o caso do A14, que afirma que o LD não é muito utilizado durante as aulas de forma que o seu grau de satisfação não poderia ser explicado:

- A14 (grau de importância "4" / grau de satisfação "4")

Eu estou de uma maneira mais neutra, pois o uso do livro não é tão intenso nas aulas.

Nesse caso, o respondente não refletiu sobre a sua resposta ou ele pode não ter entendido o que estava sendo perguntado e por isso a resposta sem um posicionamento claro. Vale notar que o uso da expressão "de forma neutra" aponta para o fato de que não houve reflexão por parte do respondente sobre a presença desse LD nas aulas. Dito de outra maneira, a neutralidade expressada pelo aluno é, em certa medida, uma forma de passividade encontrada ao longo dos dados. No entanto, ao invés de tentar disfarçar a sua resposta ou de fornecer algo não refletido, 
o respondente deixa claro que ele não pensa sobre essa questão e que aceita o uso do LD da forma como isso acontece. Caso um número ímpar de escolhas tivesse sido disponibilizado na escala, provavelmente esse aluno teria optado por um valor no meio da escala. Contudo, como não havia essa possibilidade, ele se resignou a escolher o primeiro valor do lado positivo da escala. Surge, portanto, o indício de que os alunos evitam manifestar opiniões negativas quanto ao LD e, quando o fazem, estas críticas não são claras. Dito de outra maneira: os alunos não se manifestam de forma crítica, ou porque não querem, ou por acharem que não devem fazer isso.

Por outro lado, a resposta fornecida pelo respondente A12 mostra que, ao contrário da visão do respondente tratado anteriormente, há uma certa visão crítica em relação ao LD utilizado. Neste caso, o respondente nota que o LD apresenta a língua desconsiderando variações:

- A12 (grau de importância "5" / grau de satisfação "4")

Muitas vezes enxergo que o livro didático acaba cobrando mais do que transmite ou que acaba se "fechando" em relação ao aprendizado, ou seja, o idioma parece não conter variação e ser exatamente como é descrito pelo livro didático.

Em outras palavras, para esse respondente, apesar do LD ser adequado, levando em conta 0 alto grau de satisfação anunciado na pergunta 9 do questionário, ele possui uma deficiência pelo fato de não mostrar que a língua sofre variação em diversos níveis, inclusive regional.

Quanto ao fato dos alunos não se sentirem à vontade para expressar as suas críticas acerca do LD, pode haver algumas explicações plausíveis. A primeira é que eles não consideram a sua opinião importante o suficiente para ser expressa ou, ainda, têm receio de serem julgados por expressar uma opinião negativa. Outra hipótese é que os alunos não se colocam como os protagonistas de seu processo de aprendizagem de forma que para eles tudo que estiver presente no curso é aceitável e não passível de críticas. Em outras palavras, não cabe a eles criticar já que eles não são especialistas e não vão mudar nada no curso criticando ou não o LD.

O que se verifica até aqui é que, apesar de ser possível encontrar alunos que tenham um pouco mais de visão crítica acerca do LD utilizado, a presença não refletida desse dispositivo em sala de aula gera nos alunos a tendência de construir 
visões positivas sobre o dispositivo sem que essa seja a sua opinião. O contraste entre as respostas obtidas nas perguntas em forma de escala e a explicação dada para essas opiniões, em perguntas que permitem respostas abertas, demonstra essa tendência a visões positivas que não necessariamente refletem a opinião do respondente.

Dessa maneira, nos dados obtidos nota-se que raramente o LD é claramente criticado pelos alunos de modo que se configura um cenário no qual os alunos, ou não se sentem aptos a criticar o seu LD de modo a fornecer uma visão negativa sobre o dispositivo, ou simplesmente não criticam esse material por que aquela é a única configuração possível de curso e é o que eles têm a sua disposição. Existe, portanto, uma posição de passividade assumida pelos alunos.

Além disso, não se pode deixar de lado os apontamentos de Dörnyei acerca dos problemas em se aplicar um questionário como a superficialidade das respostas obtidas e a falta de motivação dos respondentes (2003, p. 10). No contexto analisado, como o professor também era o pesquisador, talvez pudesse haver por parte dos alunos algum tipo de receio em fornecer dados muito negativos em relação ao LD utilizado em aula.

Entre os pontos positivos elencados pelos alunos para corroborar com o seu elevado grau de satisfação com o LD estão:

- Ele facilita o aprendizado;

- As unidades são bem organizadas;

- Existem revisões no fim das unidades;

- O LD fornece dicas e vocabulários úteis.

Entre os pontos negativos destacados pelos alunos e que representam uma divergência entre o elevado grau de satisfação expresso por eles estão:

- Algumas atividades não são claras;

- O LD possui enunciados confusos;

- O LD cobra mais do que oferece;

Esses tópicos, por sua vez, foram elaborados a partir da pergunta 10 da primeira etapa do questionário cujas respostas foram elencadas anteriormente e que 
pedia para que os alunos explicassem o que os fazia estar ou não satisfeitos com o LD utilizado de acordo com a resposta fornecida por eles na pergunta nove.

Levando também em consideração que o LD possui a função de organizar a macroestrutura do curso em questão, é possível aferir que provavelmente alguns alunos não se sentiram à vontade para criticar um dispositivo que tem por trás de si um autor especialista e, ainda, uma instituição que escolheu esse material. Em outras palavras, o discurso dos alunos, mesmo que de forma implícita, é carregado de certezas não refletidas que provêm em grande medida do contexto educacional no qual eles estão inseridos.

\subsection{2. "Como é o livro que eu uso?"}

Ainda sobre a importância atribuída ao LD no contexto do ensino de LE, Richards (2001) ao tratar sobre o papel e o design desse tipo de material, deixa claro que sem a sua presença, o curso deixaria de ter um núcleo e isso prejudicaria, não apenas os professores, mas também os alunos (cf. RICHARDS, 2001, p. 254). Além disso, mesmo que o autor reconheça que o LD pode não atender às necessidades dos alunos devido ao seu caráter generalizante, ainda fica evidente que, para o autor, o LD representa um dispositivo importante no contexto de ensinoaprendizagem de LE uma vez que ele não cita a possibilidade do curso ser configurado sem a presença do dispositivo.

Nesse sentido, mais uma vez o LD se mostra como um dispositivo importante no contexto de aprendizagem de LE e, portanto, sendo um material essencial para o desenvolvimento dos cursos assim como foi discutido, seria possível imaginar que sua estrutura fosse minimamente conhecida pelos alunos já que eles têm contato com tal dispositivo durante boa parte do tempo em que estudam.

Contudo, ao verificar as respostas obtidas pelos alunos do grupo pesquisado em dois momentos diferentes, surgem alguns aspectos importantes em relação à forma como a estrutura do LD se organiza. 
Neste momento, vale a pena ressaltar que muitas vezes as respostas dos alunos - assim como já foi abordado na seção anterior - parecem não demonstrar claramente a opinião deles em relação ao que lhes foi perguntado já que, em geral, muitas respostas são genéricas e pouco refletidas. Ainda sobre esse aspecto, notase que a falta de reflexão acerca da estrutura do LD é algo observável apenas a partir da falta de destreza dos alunos para manifestar ou verbalizar a sua opinião sobre essa estrutura de modo que isso passa a ser visto como uma necessidade processual - que será abordada posteriormente.

Ao pedir para que os alunos descrevam a organização das lições do LD na primeira pergunta da primeira estação durante a primeira etapa da coleta de dados, as respostas obtidas demonstram claramente essa falta de reflexão que pode exprimir essa deficiência dos alunos em manifestar ou, até mesmo, em identificar as suas necessidades. Sobre a questão específica da estrutura do LD utilizado durante as aulas, os alunos tiveram mais de uma oportunidade de refletir sobre o tema e em todas as oportunidades o que se verificou é que poucos alunos conseguiram refletir e emitir uma opinião que se aproximasse da realidade. $O$ enunciado que aparecia na estação era o seguinte:

1. Observem o índice do Kursbuch da lição 17 até a 20 e tentem entender como o livro foi desenvolvido. Respondam as questões abaixo:

b. Como cada uma das lições se organiza? Existe alguma ordem?

c. A qual lição pertencem as páginas 29 a 32 ("Zum Schluss")?

d. Para que vocês acham que serve a página 5 ?

As respostas obtidas foram as seguintes:

\section{A2 e A5}

1. a. As lições se organizam primeiro em comunicação, depois vocabulário e por fim gramática.

b. Pertence à lição 18 - Wer Gewinnt?

c. Para dar uma breve introdução do primeiro tema do livro.

\section{A7 e $\mathbf{A 1 4}$}

1. a. É organizada por cores, imagens.

b. Pertencem a Sport "Fußball".

c. Serve para falar sobre o que virá nas Lektion a seguir. 


\section{A10 e A13}

1. a. Estern*, Neue Worten, Zweiten, Verben und endlich, Fragen.

b. Lektion 18 (archtzehn)

c. (não fizeram)

\section{A11 e A12}

1. a. O livro foi desenvolvido para formar o nível de aprendizado de cada capítulo, passando por etapas como a apresentação do assunto sempre sendo explicados com algo do cotidiano, em seguida surgem os novos vocabulários e exemplos logo uma atividade dinâmica para finalmente chegar a exercícios de gramática para que o assunto se fixe e também faz facilita o entendimento. No final, tudo é revisto a partir dos verbos e vocabulários.

b. Pertence a todas as Lektions, da parte verde, desde o 17 até o 20, como uma retomada ao conteúdo.

c. Ele é como um índice do capítulo ao qual irá ser abordado, com tópicos para melhor explicar o conteúdo.

Algumas respostas demonstram claramente que não se refletiu acerca da estrutura do LD já que os alunos descrevem a organização desse material como algo feito a partir de cores e imagens por exemplo, como é o caso dos respondentes A7 e A14. Neste caso, não é possível afirmar que se trata de um discurso pronto e apenas reproduzido pelos alunos uma vez que a partir de uma afirmação tão genérica só se pode aferir que não houve reflexão e que os alunos quiseram, mesmo assim, fornecer alguma resposta.

Além disso, existem algumas respostas que chamam a atenção devido ao fato de que, na tentativa de explicar a estrutura do LD, alguns alunos demonstram a importância que eles dão ao aspecto gramatical em detrimento de outros aspectos também relevantes para o LD. Dito de outra maneira, mesmo quando reconhecem a presença de elementos que priorizam a comunicação como pode ser visto nas respostas de $\mathrm{A} 2$ e $\mathrm{A} 5$, os elementos gramaticais acabam se sobressaindo a eles na visão dos alunos.

No LD utilizado nas aulas do grupo estudado - o livro Planet $A 2$ - existe uma divisão clara de módulos temáticos. Cada um desses módulos é constituído por quatro capítulos que por sua vez apresentam subdivisões do grande tema que o módulo apresenta. Ao final desses quatro capítulos, há duas seções intituladas Das kann ich schon e Zum Schluss, nas quais os alunos, além de revisarem o conteúdo visto durante os quatro capítulos anteriores, podem realizar atividades diversas, tanto de fundo comunicativo, quanto de fundo gramatical. Uma simples vistoria pelo 
índice desse LD já possibilitaria ter uma visão geral dessa estrutura uma vez que, além da divisão temática, existe um apelo visual muito forte de modo que cada bloco temático é representado por uma cor. No momento em que a atividade foi realizada, havia vários exemplares do Kursbuch sobre a mesa de modo que teria sido possível consultar o material e analisá-lo.

Apesar de relativamente simples, como houve discordância entre os alunos em relação à presença dessas seções, surge o indício de que eles realmente não procuraram saber ou não conseguiram entender como o LD está organizado. Em outras palavras, o fato dos alunos não conseguirem descrever, mesmo que de forma mínima, a estrutura do LD utilizado por eles mostra, por um lado, que talvez eles nunca tenham tido um espaço para que houvesse tal reflexão e por isso as respostas obtidas não são refletidas e, por outro lado, mostra que, apesar da importância e das funções atribuídas ao LD, os alunos não chegam a se apropriar dele como uma ferramenta de estudo e, portanto, não o conhecem como deveriam. Cabe ressaltar que, durante as aulas, os alunos não são estimulados a observar o índice do LD e que, além disso, muitas vezes não há tempo hábil em aula para fazer uma reflexão acerca dos aspectos estruturais do LD utilizado.

Nesse sentido parece que surge uma espécie de hierarquia nesse contexto no qual existe um LD que norteia o trabalho do professor e o próprio funcionamento do curso, um professor que trabalha apoiado no LD e, por fim, os alunos que seguem as instruções desse professor sem, no entanto, se apropriar desse LD. Dito de outra forma, o aluno se coloca de forma passiva em relação ao LD utilizado de modo a não se sentir apto o suficiente para criticar ou sugerir mudanças. Dessa forma, o que se configura é uma sobreposição de necessidades: como o LD foi escolhido previamente e como o professor o utiliza como base para a preparação das aulas bem como para organizar os conteúdos que serão aprendidos e a ordem em que isso vai acontecer, a posição passiva adotada pelos alunos configura um contexto no qual esses alunos não se sentem preparados para discutir e externar as suas necessidades de modo que as necessidades objetivas sobrepõem de certo modo às subjetivas. 


\subsubsection{Representações e expectativas}

A inexperiência observada em relação à reflexão dos alunos acerca do LD não condiz necessariamente com algum tipo de inexperiência em relação a aprendizagem de LE no geral. Assim como aponta Ferrari (2014), raramente o alemão é a primeira LE com a qual os alunos têm contato, uma vez que o inglês é amplamente oferecido nas escolas de ensino regular, sobretudo a partir do segundo ciclo do ensino fundamental assim como discutido na seção 2.1.1. deste trabalho. Vale ressaltar que os dados obtidos a partir do segundo questionário apontam para o fato de que todos os alunos do grupo pesquisado já tiveram contato com outros idiomas, tanto no CEL, quanto no ensino regular ou em escolas de idiomas.

No contexto específico analisado, tal informação se confirma quando se nota que todos os alunos que participaram da pesquisa afirmaram ter contato com outras línguas estrangeiras, seja no próprio $\mathrm{CEL}$, no ensino regular, ou em outra instituição de ensino. Neste ínterim, pensando na importância atribuída ao LD no contexto de ensino de LE assim como já foi discutido, a experiência dos alunos com a aprendizagem de outros idiomas torna plausível a ideia de que eles já teriam, portanto, experiência no manuseio de diversos LD de modo que, mesmo considerando que eles nunca tenham tido um espaço para refletir sobre isso, existiria no imaginário desses alunos ao menos algum protótipo do que seria uma configuração eficiente desse tipo de material.

A partir dessa premissa, tratamos de uma atividade proposta na segunda etapa da coleta de dados e que pedia para que os alunos fizessem um esboço do que seria uma Einstiegsseite, já que esse elemento estava presente no livro Planet A2.

Obviamente, ao se pensar em questões de tempo e de materiais disponíveis, já era esperado que nenhum dos grupos elaborasse algo inovador, no entanto, era esperado observar em que medida esses alunos seriam capazes de se distanciar ou de se aproximar do original disposto no LD de forma a criar algo que demonstrasse um pouco sobre como esse elemento figura nos imaginários deles. 
Sobre essa atividade, o que se observa no geral é que os alunos não foram capazes de notar os elementos que constituíam aquela página inicial como os subtemas que serão abordados ao longo dos quatro capítulos que constituem aquele bloco temático e os objetivos de aprendizagem que priorizam aspectos comunicativos e não gramaticais. A partir da não observância desses fatores, notase que houve a tentativa, ou de reproduzir o design já utilizado pelo próprio LD, ou ainda, a tentativa de fazer uma colagem com os materiais que estavam disponíveis sobre a mesa no momento em que a atividade foi feita e que não necessariamente reproduz o imaginário desses estudantes em relação ao LD em si, mas demonstra a tentativa de cumprir a atividade que era proposta sem que houvesse uma reflexão aprofundada sobre o assunto.

Entre os grupos participantes da pesquisa, um deles tentou demonstrar através de linhas que ligavam os capítulos entre si qual era uma das funções dessa página inicial. Em outras palavras, o grupo foi capaz de notar que esta página inicial abarcaria os quatro capítulos que compõem o módulo temático e, dessa forma, como isso fica evidente apenas no índice, mas não nessa página, os alunos indicaram que talvez fosse importante mostrar para eles de forma clara e direta o que uma Einstiegsseite abarca já que não é claro do ponto de vista do aluno o que aquela página representa. A atividade feita por esse grupo foi a seguinte:

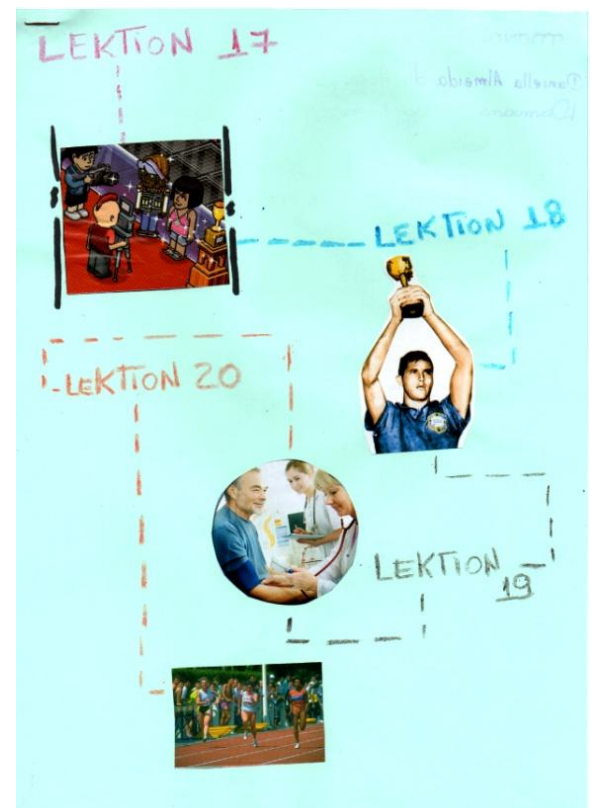


Houve também grupos em que a atividade, apesar de ter sido realizada, indica que não houve tanta reflexão por parte dos respondentes, uma vez que se trata de várias colagens com algumas frases:

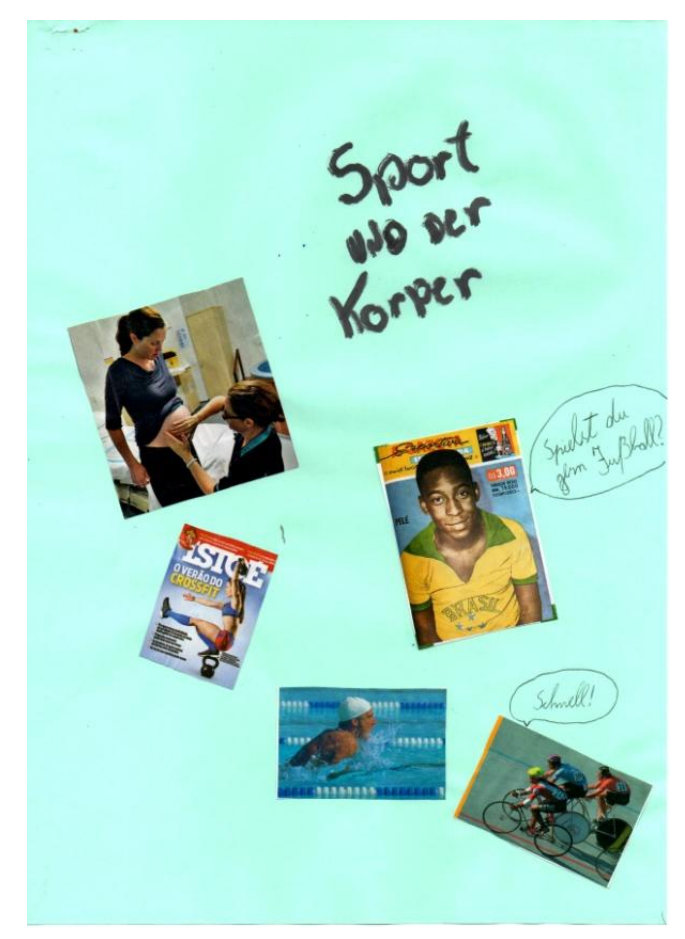

Figura 3: Einstiegsseite produzida pelos respondentes A7 e A10

Outro ponto a ser observado trata acerca da opinião dos alunos em relação ao que seria para eles um LD ideal. Neste momento, a falta de experiência observada ao refletir sobre o dispositivo se revela também a partir das colocações feitas por eles. Existem algumas afirmações muito amplas e generalizantes que pouco transparecem a real visão dos respondentes.

Primeiramente, as respostas fornecidas por A2 e A6 podem ser classificadas entre as respostas generalizantes:

A2

O livro didático ideal seria aquele que possui imagens explicativas, pequenos resumos com palavras mais fáceis, um padrão de exercícios e com textos não muito extensos. 
A6

llustrado, separado em tópicos que aborde gramática, fonética, cultura e interpretação.

Já a resposta fornecida pelos alunos A5 e A7 partem do pressuposto de que os alunos nunca pensaram em um LD ideal de modo que surge a premissa de que, para eles, todos os LD seriam igualmente bons em termos de qualidade e, portanto, não haveria a necessidade de refletir sobre eles uma vez que, caso isso fosse feito, teria que se admitir que nem todos possuem a mesma qualidade:

A5

Nunca pensei como seria um livro ideal, pois o livro didático que temos já é suficiente para entendermos e estudar. E se fosse mudar uma coisa seria que pudéssemos levar o livro pra casa para conter mais aprendizado.

A7

Nunca pensei, mas em minha opinião acho que teria que detalhar bem os exercícios para deixar bem explicado bem específico.

Ainda de acordo com a resposta do aluno A5, o uso da palavra "conter" indica que para o aluno o próprio LD já é sinônimo de aprendizado, como se nele contivessem todos os elementos necessários para o aprendizado sem que esse material precisasse ser operacionalizado.

No caso da resposta fornecida por A10, o que fica evidente não é a estrutura do LD em si, mas sim, a maneira de usá-lo. Dito de outra forma: observando a resposta do aluno, nota-se que também não houve reflexão sobre o LD ideal já que o aluno parece não saber que há resumos dos conteúdos no final das unidades, além de precisar de mais conteúdo audiovisual como "conteúdo de aula":

A10

Sim, um livro que pudesse ser levado para casa, e que tivesse, além de conteúdos da aula, áudios com pronúncias, resumos de matérias e indicações de filmes, séries, etc.

Prosseguindo na observação das respostas para esta pergunta, a visão do respondente A11 acerca do que seria um LD ideal revela a ideia de um dispositivo que possui diversas funções dentro do curso de alemão, inclusive - de acordo com essa visão - o dispositivo adquire funções que são do professor como promover o debate entre os alunos. Cabe também ressaltar que, neste caso, há uma crítica direta aos tipos de exercícios que LD oferece: 


\section{A11}

Acredito que um bom livro didático é ser auto explicativo (apesar do alemão não ser uma língua de fácil entendimento), exemplificando, com uma base favorável de exercícios diferentes, um livro que estimule o debate entre os alunos, que sucumba as dúvidas e que torne mais dinâmica a aula.

No caso da resposta fornecida pelo respondente $A 12$, surge claramente a ideia de que não houve reflexão efetiva acerca do que seria um LD ideal uma vez que o aluno elenca elementos que já estão presentes no LD utilizado pelos alunos, assim como as dicas. Nesse sentido, nota-se que o aluno não está familiarizado com o contexto de produção de um LD internacional que não pode trazer dicas de séries e filmes para o contexto brasileiro, já isso descaracterizaria o material. Nesse sentido, o aluno parece não diferenciar o que é função do LD e o que é função do professor do curso, de modo a fazer sugestões indiretas para o trabalho do professor em atividades que tratam sobre o LD:

\section{A12}

Um livro didático que além de revisar a unidade, possuíssem capítulos específicos para que tudo o que foi aprendido seja revisado. Poderia existir também unidades com o intuito da produção textual, ou até mesmo dicas do que poderíamos ler ou assistir para que possamos adquirir mais vocabulário, além do oferecido.

Resumindo, a partir dos dados obtidos com essa pergunta, para esses alunos, um LD ideal teria, de acordo com as respostas dos alunos:

- Cores;

- Exercícios de fácil compreensão;

- Dicas de filmes e séries;

- Informações culturais;

- Resumos dos conteúdos já vistos.

A partir desses tópicos, transparece em grande medida a forma como os alunos encaram o LD. Por um lado, há elementos que eles citam, mas de forma muito vaga e há elementos que, apesar de já estarem presentes no LD utilizado, não são percebidos por eles. Dito de outra forma, no caso específico dos "resumos dos conteúdos já vistos", percebe-se que os alunos, ou não percebem que esse 
elemento é comum no LD utilizado por eles, ou que a apresentação desses resumos não atende às suas expectativas.

Desse modo, a expectativa dos alunos em relação a um LD ideal está resumida a realidade que já é conhecida por eles sem que haja a reflexão do que seria útil para o seu contexto de aprendizado. Nesse sentido, com exceção do tópico "dicas de filmes e séries" que de certa poderia ferir o princípio de que um LD deveria ser durável por questões de mercado, todos os outros tópicos são encontrados no próprio LD utilizado pelos alunos durante as aulas.

Mesmo que haja essa divergência em relação ao que seria para os alunos um LD ideal, o fato é que existem os fatores que colaboram para que eles gostem ou não desse material assim como será abordado na seção 5.2.4.

Não se pode ignorar, por fim, o fato de que o livro utilizado no contexto estudado foi desenvolvido levando em conta as premissas do Quadro Europeu Comum de Referência para as Línguas e que, portanto, possui uma clara preferência pela abordagem orientada para a ação Handlungsorientierung já que isso é uma tendência do próprio QECR (CONSELHO DA EUROPA, 2001). Dessa forma, mesmo que exista uma certa liberdade em relação ao design e a progressão do material, é de se esperar que todos os materiais elaborados com essa premissa tenham características semelhantes. Além disso, também não se pode excluir o fato de que por trás de todo LD existe um apelo mercadológico muito grande, de modo que a sua configuração também levará em consideração esses aspectos de forma que aspectos relacionados a design, organização e audiovisual, que foram elencados pelos alunos como sendo relevantes, serão contemplados nesses LD.

\subsubsection{Fatores valorativos do LD}

Assim como aponta Tomlinson (2011, p. x), o LD - sobretudo o livro de curso - é configurado de tal maneira que poderia ser o único material utilizado tanto pelo professor, quanto pelos alunos de um curso. Além disso, ao lembrar da importância atribuída a esse material e do papel que ele exerce no imaginário dos alunos, aliada à forte presença desse dispositivo durante as aulas, surge a premissa de que há, por 
parte deles, alguns fatores que podem ser utilizados para atribuir valor afetivo a esse material.

Portanto, mais do que buscar frases generalizantes, o questionário - na primeira parte - buscava fazer com que os alunos, após um período de reflexão sobre o tema, tivessem um espaço para argumentar acerca do que faz com eles gostem ou não do material utilizado durante as aulas. Vale lembrar que o material, assim como ocorre em grande parte dos cursos de LE, é escolhido levando em consideração uma série de fatores e que, muitas vezes, nem mesmo os professores são responsáveis por tal escolha.

As perguntas do questionário que se relacionavam com esse ponto pediam para que os alunos completassem uma frase circulando o conetivo utilizado (perguntas 11 e 12 do primeiro questionário) de forma a expressar a sua opinião acerca do que os faz gostar e não gostar do LD utilizado. A pergunta 12 traz o "não" como premissa para a resposta do aluno:

A2

11- QUANDO é utilizado como ferramenta de explicação.

12- QUANDO é utilizado rapidamente e não há um aproveitamento das demais lições.

A5

11 - QUANDO tem exercícios fáceis e menos complexos e temas que eu não conheço.

12- POIS alguns exercícios eu não entendo ou fique em dúvida.

A6

11 - POIS é ilustrado e de fácil compreensão.

12 - QUANDO tem questões muito difíceis.

A7

11- QUANDO os assuntos são contínuos.

12- QUANDO de um exercício para o outro o assunto muda totalmente.

A10

11- QUANDO utilizado para reforçar vocabulários e como exemplo na aula.

12- QUANDO é utilizado como única fonte para a resolução de exercícios.

A11

11 - QUANDO as atividades são auto explicativas e favorecem em uma aprendizagem mais rápida.

12 - QUANDO possui dentro de um mesmo assunto, a retomada maçante de termos, ou atividades quase "iguais". 


\begin{abstract}
A12
11- POIS podemos considerá-lo a maneira mais explicativa e adequada para o aluno ter contato com o idioma.

12- QUANDO ele acaba misturando o que está sendo aprendido no momento (na maioria das vezes vocabulário) com o que já foi visto como os pronomes possessivos, por exemplo. Para que os dois se unam devem estar localizados no local voltado para revisão.
\end{abstract}

A14

11- POIS ele auxilia no aprendizado de uma maneira geral.

12- Não respondido

Vale ressaltar que a visão de $\mathrm{A} 12$ em relação à pergunta 11 corrobora com o ponto exposto anteriormente relacionado ao fato de que o LD é às vezes a única fonte de contato com a língua-alvo, no caso, o alemão.

De maneira geral, o que se observa é que os alunos, apesar de se esforçarem para fornecer a sua visão sobre o LD, eles nem sempre conseguem se expressar de forma clara. Em vários enunciados, os alunos revelam que esperam que o LD seja autoexplicativo e que se organize passo a passo sem misturar conteúdos até que eles tenham sido tratados de maneira exaustiva. No entanto, um LD que apresentasse essa característica não seguiria os princípios da Handlungsorientierung - como os atuais LD fazem - mas seria apenas um compilado de textos, exercícios gramaticais e vocabulário. Nesse sentido, há uma disparidade entre a abordagem utilizada pelo LD e a abordagem mais estrutural que é vislumbrada pelos alunos. Contudo, os alunos também não percebem que essa estrutura de LD vislumbrada por eles não vai levá-los a conseguir utilizar o idioma em situações comunicativas.

Com isso, as respostas obtidas dificilmente apontam para a verdadeira opinião dos respondentes e tendem a ser generalizantes e neutras, portanto. Nesse sentido, pensando por enquanto na pergunta 11, que pedia para que os alunos escrevessem o que os faz gostar do LD, os argumentos utilizados tendem a tratar sobre a complexidade de exercícios e sobre a forma como o LD é utilizado:

- É utilizado como ferramenta de explicação;

- Tem exercícios fáceis;

- Apresenta temas desconhecidos;

- É ilustrado; 
- Reforça vocabulários;

- É usado como exemplo na aula.

Vale notar o que alguns desses elementos apontam para possíveis relações estabelecidas entre os alunos e o LD. Quando dizem gostar do livro sendo utilizado como ferramenta de explicação nas aulas, surge o indício de que não apenas o LD utilizado em aula, mas sim a sua presença é valorizada. Dito de outra forma, os alunos esperam um LD mais atraente para eles no sentido de ser estrutural e fácil, no entanto, eles não conseguem perceber que o LD utilizado tem uma proposta de ensino que vai na contramão de suas expectativas, já que ele não pode ser só estrutural e fácil.

Ainda sobre a presença do LD em aula, ao afirmar que gostam do LD quando ele é usado como exemplo nas aulas, surge um possível contraste em relação ao que foi expresso por outros alunos já que, a partir do momento em que se percebe a presença constante do LD nas aulas, afirmar que ele é utilizado como exemplo abre a premissa de que o curso não seria orientado por esse dispositivo e que apenas às vezes ele seria suscitado como exemplo para a realização de exercícios ou para a escolha de temas. Vale ressaltar que, mesmo alguns alunos tendo afirmado que o LD não é utilizado com frequência nas aulas, essa informação parte da percepção de alguns alunos e não há consenso sobre isso já que as respostas são diversificadas.

Em determinado ponto, o aluno A12 afirma gostar do LD por ele poder ser considerado "a maneira mais explicativa e adequada para o aluno ter contato com o idioma". Com isso a visão de que o LD ocupa um lugar importante no imaginário dos alunos é reforçada e, além disso, a utilização da palavra "adequada" demonstra a valoração positiva que se faz do LD neste caso já que, mais do que outros elementos possíveis comumente valorizados pelos alunos como filmes e músicas, aqui o LD é visto - mesmo que de forma implícita - como um dispositivo que carrega em si os elementos metodológicos necessários e pensados para proporcionar o aprendizado da LE.

Há, contudo, os elementos que demonstram a valoração negativa que se faz desse dispositivo. Neste caso, analisando as respostas obtidas na questão doze da primeira parte do questionário, nota-se que a atribuição de valor para este aspecto 
está diretamente relacionada à forma como os alunos estudam e o seu grau de compreensão dos exercícios propostos. Entre os principais motivos elencados pelos alunos neste caso estão:

- Quando o LD mistura conteúdos já aprendidos e conteúdos novos;

- Quando é pouco utilizado;

- Quando tem exercícios de difícil compreensão;

- Quando é a única ferramenta utilizada em aula.

Em relação a estes aspectos há uma série de questões que podem ser observadas e que apontam para possíveis divergências acerca da opinião dos alunos e o papel atribuído ao LD.

Primeiramente, ao afirmarem que não gostam que o LD misture conteúdos, os alunos ignoram, por um lado, o fato de que estudar uma LE envolve conteúdos de várias ordens e que, além disso, existe muitas vezes um caráter cíclico neste dispositivo que atua de forma a abordar um conteúdo diversas vezes através de etapas assim como descrevem Rösler e Würffel (2014). Por outro lado, essa mesma afirmação também aponta para uma característica desses alunos que não percebem muitas vezes que o ensino de LE depende em grande medida de continuidade e progressão. Dessa forma, os conteúdos estão interligados entre si e não devem ser deixados à margem no momento em que outros conteúdos são apresentados.

Sobre este aspecto, não se pode ignorar o fato de que esses alunos estão inseridos em um meio educacional e que trazem consigo uma série de juízos de valor formados em relação ao processo de aprendizagem, seja de LE, seja de outras disciplinas. Nesse sentido, o caráter estrutural verificado em algumas setenças demonstra também um vício de aprendizagem que vem do ensino regular, uma vez que - mesmo nas aulas de LE - existe um caráter conteudista muito forte que deixa de lado a ideia da progressão nos moldes em que os atuais LD internacionais de LE apresentam.

Ao afirmarem que não gostam quando o LD é pouco utilizado nas aulas aparece mais uma vez a importância que é atribuída ao dispositivo, pois neste caso, o fato de não gostar quando o LD é pouco utilizado demonstra que - mesmo que de maneira implícita - os alunos notam e valorizam a presença do LD nas aulas. 
Contudo, não se pode excluir o fato de que o aluno $\mathrm{A} 2$ também afirmou que não gosta quando o LD é utilizado como única ferramenta de explicação, de modo que se configura um contexto no qual é possível aferir que os alunos não possuem uma opinião clara acerca do tema e que, por isso, as respostas divergem tanto entre eles.

\subsubsection{O LD e o estudo fora das aulas}

Apesar de sua presença durante as aulas, não se pode negar o fato de que o estudo fora do horário de aulas é também essencial para o processo de aprendizagem de uma LE já que apenas as poucas horas semanais de aula não são suficientes para que os alunos pratiquem, façam exercícios e tirem todas as suas dúvidas. Em outras palavras, o estudo em casa complementaria o que foi visto durante as aulas e contribuiria para 0 desenvolvimento das competências necessárias para que o aluno se comunique utilizando a LE.

No entanto, a partir desse contexto analisado no qual a escola não pode ceder LD para que cada aluno possua uma cópia, cabe averiguar quais são os elementos utilizados por esses alunos para estudar em casa.

Primeiramente, antes de tratar sobre os dados empíricos que revelam a forma como os alunos estudam em casa, vale ressaltar que ainda no primeiro questionário, ao tratar sobre um LD ideal, o respondente A5 levanta a possibilidade de que o LD utilizado no curso, ainda que atenda às suas necessidades, deveria poder ser levado para casa para que os alunos pudessem utiliza-lo como ferramenta de estudos:

Nunca pensei como seria um livro ideal, pois o livro didático que temos já é suficiente para entendermos e estudar. E se fosse mudar uma coisa seria que pudéssemos levar o livro pra casa para conter mais aprendizado. (Respondente A5 - pergunta 15)

Partindo, portanto, da hipótese de que o LD é visto pelos alunos como um dispositivo importante não apenas para as aulas, mas também para o estudo em casa, cabe notar se isso realmente se concretiza a partir de outras respostas fornecidas pelos respondentes na segunda etapa do questionário que também tratou sobre essa questão. 
Nesse sentido, sobretudo as questões 8 e 9 da segunda etapa do questionário podem ser utilizadas para tratar sobre o fato de como os alunos enxergam a importância de se ter ou não um LD para ser utilizado em casa.

Em relação à questão 8 , em uma escala que ia até seis, onde "1" representava "pouca importância" e "6" representava "muita importância", cinco respondentes, de um total de sete, escolheram a opção "6". Dessa forma, o primeiro indício é de que todos esses cinco respondentes reconhecem a importância de se ter uma cópia do dispositivo para estudar em casa. Quando explicam a sua opinião sobre essa questão, as respostas obtidas apresentam diversas visões sobre o fato:

A1

Creio que um auxilio didático dentro de casa nos faz mais capazes de aprender

A2

O livro supriria a necessidade de praticar o que foi passado em sala

A5

Eu não tenho, mas eu acho importante, pois nele dá para tirar dúvidas, fazer atividades etc.

A7

Tem importância para as lições de casa e para sempre estudar e fazer os exercícios.

A10

Considero importante, mas não obrigatório, pois o livro tem uma metodologia de ensino que pode ser super aproveitada pelo professor.

A11

Os livros são materiais de apoio, ou seja, somente as 4 horas, as quais passamos no curso não são suficientes, fazendo com que seja necessário nos aprofundarmos no assunto que tivemos no curso, revisarmos, fazer os exercícios, tudo para favorecer uma melhor aprendizagem.

A12

Por ser uma língua não muito falada, ainda mais no Brasil, o livro didático parece ser a bussola essencial para nos guiar no aprendizado do alemão.

Por mais que haja respostas generalizantes, algumas delas chamam a atenção pelo fato de revelarem um pouco sobre a visão desses alunos em relação ao dispositivo.

No caso do respondente A1, fica claro que o LD é visto como um dispositivo que auxilia no processo de aprendizagem; a frase "mais capazes de aprender" denota que há no respondente o reconhecimento de que sem esse dispositivo o 
aprendizado seria mais difícil. Em outras palavras, o respondente nota que o LD organiza o seu estudo, tanto dentro, quanto fora da sala de aula. No mesmo sentido, a resposta do aluno $A 12$, por sua vez, traz uma linguagem metafórica que, por um lado, reforça a ideia da importância do LD para o aprendizado de alemão e que, por outro, traz uma visão que corrobora com o que foi exposto anteriormente sobre o fato do LD ser o único dispositivo com o qual se tem contato durante o estudo de uma LE, o que reforçaria a sua importância para esse contexto.

Outras respostas gerais denotam também a importância do LD para atividades comuns na aprendizagem de LE já que apontam o dispositivo como uma ferramenta importante para se fazer lições de casa, tirar dúvidas e reforçar o que foi estudado em sala de aula.

Contudo, a resposta fornecida pelo respondente A10 demonstra que o aluno atribui ao LD um papel importante para a aula, mas não para o seu estudo individual em casa. Neste ínterim, o que se verifica é que, ao colocar a figura do professor como o ponto central da sua pesquisa, o respondente se exime da responsabilidade de assumir realmente a importância do LD para si. Visto sobre outro viés, o LD para esse respondente não ocupa uma posição tão central quando ele pensa nos seus estudos em casa.

Mesmo a partir da observância desses dados, nota-se aqui que essas respostas não demonstram necessariamente a realidade dos alunos já que, por um lado, eles afirmam que é importante ter um LD para estudar em casa e, por outro lado, quando é perguntado a eles a quantidade média de horas que eles estudam alemão em casa, a maioria das respostas aponta para o fato de que muitos estudam menos de uma hora por semana. Além disso, apesar de considerarem o LD como uma importante ferramenta de estudo em casa, três dos sete respondentes afirmam que não possuem cópias nem exemplares desse material, os demais, apesar de afirmarem que tem pelo menos uma versão em PDF ou do Kursbuch ou do Arbeitsbuch, não faziam atividades alegando que não tinham o livro (será tratado na seção 5.3.3). Dessa forma, nota-se uma inconsistência nas informações fornecidas já que, apesar de considerar importante, muitos alunos - mesmo sabendo que o LD seria utilizado por pelo menos um ano e meio - não optam por adquirir uma cópia. 
Outro fator que chama a atenção em relação à relevância do LD para o estudo em casa é observado na questão 15 do segundo questionário, que pedia para que os alunos elencassem - de acordo com o grau de importância - os materiais que eles utilizavam para estudar em casa. Neste caso, o LD aparece na resposta de apenas três respondentes, dos quais, dois o colocam em primeiro como material mais importante:

A1

1. Listas de palavras/2. Aplicativos/3. Sites/4. Vídeos A2

1. Livro didático de exercícios/ 2. Dicionário/ 3. Aplicativos de celular/ 4. Conteúdo da internet.

A5

1. Aplicativos de celular/2. Dicionários/3. Listas de palavras/4. Não escreveu nada.

A7

1. O livro didático/2. Dicionário/3. Aplicativo/4. Não escreveu nada.

A10

1. Listas de palavras/2. dicionários/3. Aplicativos/4. Livro didático.

A11

1. Guias de conversação/2. Dicionários

A12

1. Listas de palavras/2. Aplicativos/3. Vídeos (Filmes, séries, desenhos)/ 4. Dicionários.

A partir das respostas obtidas nota-se a inconsistência no discurso dos alunos em relação à importância do $L D$ e também há o indício de que o LD não é a primeira ferramenta da qual eles se lembram ao pensar em estudos em casa. Contudo, também não se pode ignorar o fato de que ao mencionar elementos como "listas de palavras", "conteúdo da internet" ou "vídeos", os alunos demonstram que para eles a reflexão sobre a língua que é oferecida pelo LD é deixada à margem em detrimento do aprendizado de vocabulário descontextualizado ou de vídeos e músicas que não necessariamente contribuem para o desenvolvimento das capacidades desse aluno uma vez que não há como afirmar que esses alunos escutam esses vídeos e músicas de forma didática, ou seja, estudando. 


\subsection{Necessidades processuais}

Retomando o conceito descrito na seção 2.1.2. - Tipos de necessidades - as necessidades processuais caracterizam-se como sendo aquelas que são observadas pelo professor levando em consideração o local onde o curso é oferecido e, ainda, os materiais e a forma como eles são utilizados assim como também descreve Weissenberg (2012).

Apesar das necessidades subjetivas ocuparem o centro das discussões nesta pesquisa, os dados mostraram que os alunos muitas vezes não são capazes de expressarem de forma clara as suas necessidades em relação ao LD utilizado durante as aulas. Dessa forma, existem fatores que configuram necessidades processuais, uma vez que são observáveis pelo professor-pesquisador a partir da situação em que os alunos estão inseridos.

\subsubsection{Refletir sobre o LD na presença do professor/ pesquisador}

Refletir sobre o LD não é uma questão muito comum no meio estudantil já que, por vezes, o contexto que se observa consiste justamente em uma relação vertical na qual o aluno está em último lugar. Dito de outra maneira, questões relacionadas à estrutura dos cursos e aos materiais que são utilizados neles são pré-determinadas por outras instâncias e não podem ser mudadas, além disso, notase a resignação dos alunos em relação a essas condições já que eles ou não se sentem aptos a expressar uma opinião sobre possíveis mudanças, ou não o fazem por achar que aquela é a única estrutura possível de curso para aquele contexto do CEL.

Além disso, a presença do LD assim como outras obrigatoriedades do curso, como a quantidade mínima de presença necessária para aprovação por exemplo, apesar de questionáveis, não costumam ser amplamente discutidas uma vez que os alunos costumam assumir uma posição passiva em relação a esses aspectos. Outro fator importante que se relaciona de forma direta com o contexto analisado e, ainda, de maneira mais ampla, com o contexto educacional brasileiro, consiste justamente 
no fato de que, às vezes, não há tempo hábil nos cursos para que professores, equipe gestora e alunos possam discutir diretamente aspectos relacionados aos cursos como a escolha do LD e os objetivos do curso.

Nesse sentido, levando em conta que não é comum a ampla discussão acerca do LD utilizado nos cursos, os dados revelam que há por parte dos alunos do grupo analisado a tendência a ser sempre positivos em relação às opiniões que são expressas acerca do dispositivo (discutido na seção 5.2.4.). Com isso, o que se verifica é que os alunos tiveram dificuldades em expressar a sua opinião clara em relação ao LD utilizado já durante as estações de trabalho que continham atividades diversificadas. Como exemplo, é possível citar as atividades da segunda estação Übungen im Arbeitsbuch - realizada no segundo dia da coleta de dados. O enunciado da primeira pergunta desta estação era o seguinte:

1. Observe a unidade 19 do Arbeitsbuch e reflita (anote suas conclusões na folha branca sobre a mesa, use uma caneta para escrever suas observações):

a. Existe alguma ordem na escolha em que os exercícios aparecem? É possível perceber algum tipo de ligação com o que foi visto no Kursbuch? (resposta no envelope verde)

b. A página inicial das unidades do Arbeitsbuch e a seção intitulada DAS HAST DU GELERNT são também exercícios ou têm outro tipo de função? (resposta no envelope verde)

Quadro 44: Pergunta 1 da primeira estação do segundo dia de coleta de dados

Ao observar as respostas para essa pergunta, nota-se que há, por um lado, grupos que conseguem fornecer uma opinião concreta e plausível acerca do LD. Por outro lado, há respondentes que fornecem respostas confusas e que demonstram que houve pouca reflexão sobre o que foi escrito.

No caso dos alunos A2 e A14, que formaram uma dupla do dia em que a atividade foi aplicada, a resposta fornecida para essa questão corrobora com o fato de que algumas vezes há pouca reflexão acerca da estrutura do LD e, ainda, corrobora com o fato de que não é comum que o aluno tenha espaço para fazer tal reflexão, de modo que há o estranhamento quando esse embate é realizado:

1. A. Aparentemente não, os exercícios só estão voltados ao mesmo tema. No Kursbuch se introduz o tema, a parte mais teórica, estimulando a parte prática, o Arbeitsbuch.

B. A página DAS HAST DU GELERNT tem por objetivo perguntar diretamente para o estudante se ele aprendeu ou não os conteúdos de cada parte do livro. Ambas as páginas são basicamente exercícios. 
Cabe notar que, quando questionados sobre a ordem em que os exercícios aparecem no Arbeitsbuch, os alunos não foram capazes de perceber que há o critério da complexidade desses exercícios no dispositivo de modo que os exercícios são oferecidos sempre a partir do mais simples para o mais complexo.

Contudo, para os respondentes, a resposta denota que a escolha das atividades do Arbeitsbuch leva em conta apenas o tema que é tratado no Kursbuch de modo que o livro de exercícios serviria como ferramenta para a prática do que foi estudado com o livro de sala.

Em oposição a essa resposta, os alunos A5, A6 e A12 apresentam uma visão mais estruturada e refletida acerca dessa mesma pergunta:

1. A. segue a mesma sequencia do livro "Kursbuch" porém os exercícios aparecem de forma a se tornarem mais complexos conforme as unidades de ambos os livros vão se aprofundando no assunto se percebe também uma espécie de sequência no que diz respeito a gramática, vocabulário e interpretação.

B. É um tipo de exercício, porém, com uma função diagnóstica para que o professor tenha um controle ou saiba até mesmo como ajudar os alunos com dificuldade na atividade. Em suma, é uma revisão que propõe uma autoavaliação do aluno.

Ao analisar a resposta do item "a" da pergunta, fica nítido que os alunos notaram que, além de seguir a sequência do Kursbuch em relação aos temas e tópicos estudados, também há a utilização do critério da complexidade e da progressão, não apenas no que diz respeito aos aspectos gramaticais, mas também a outros aspectos também relevantes para o estudo de LE.

Contudo, a resposta do item "b" dessa pergunta revela uma posição importante dos respondentes acerca do papel desempenhado pelo LD. Ao afirmarem que a seção Das Hast du Gelernt possui uma função diagnóstica, os alunos validam o fato de que houve uma reflexão efetiva sobre esse determinado aspecto do LD. Contudo, cabe ressaltar que a resposta apresenta uma ambiguidade já que, por um lado, os alunos reconhecem a função da seção, porém, por outro lado, atribuem tal seção ao professor para que ele possa se utilizar disso para controlar de alguma forma o processo de aprendizagem dos alunos. Nesse sentido, há um deslocamento de importância já que os alunos parecem não se apropriar do LD com uma ferramenta importante para o seu próprio desenvolvimento quanto ao processo de aprendizagem de alemão e, apesar de terem percebido que o aluno 
também pode se autoavaliar, eles ainda atribuem essa tarefa ao professor. Talvez essa atribuição de avaliação ocorra devido ao fato que não é ainda comum para eles se avaliar, de forma que eles precisam de uma avaliação que não parta deles, mas sim, da figura que detêm autoridade para fazer uma avaliação nos moldes em que eles conhecem. Dito de outra maneira, não basta para eles refletir sobre o seu processo de aprendizagem e se autoavaliar, eles precisam de uma sanção positiva ou negativa que venha através do professor.

Além disso, outro fato que não pode ser desconsiderado e que contribui em grande medida para que as respostas sejam divergentes consiste no fato da figura do pesquisador e do professor da turma estarem concentradas na mesma pessoa. Dito de outra forma, o que se notou nos alunos durante as diversas coletas de dados é que, muitas vezes, havia uma certa insegurança deles em relação ao que exatamente deveria ser feito em cada uma das atividades e também no questionário.

Nesse sentido, sobretudo no primeiro dia da coleta de dados, ficou claro que os alunos não conseguiram aceitar o fato de que a pesquisa seria feita sem julgamentos. Dessa forma, a tendência a fornecer respostas sempre positivas denota que eles buscam não se expor de forma negativa e, além disso, denotam também que eles buscam agradar ao pesquisador através de suas repostas. Devido a esse fato, as respostas apresentam, além da já citada tendência positiva, traços generalizantes sobre os quais tratarei de maneira mais detalhada na próxima seção.

\subsubsection{Como estudar uma língua estrangeira?}

Ao tratar acerca do estudo de uma LE, não se pode ignorar o fato de que, além do estudo, é preciso ter em vista que a progressão é um fator relevante para que o aluno vá - aos poucos - aprendendo estruturas gramaticais, vocabulário e demais aspectos da língua em um determinado espaço de tempo. Além disso, o estudo de uma LE denota tempo e exige que o aluno entenda que o curso não se trata de conteúdos independentes que devem ser esquecidos após uma prova ou depois do fim de um bimestre, por exemplo. Contudo, analisando o contexto do CEL no qual a pesquisa foi realizada, o que se observa é que os alunos carregam uma 
visão muitas vezes diferente desta que foi apresentada acerca do processo de aprendizagem de uma LE.

O primeiro fato que chama a atenção nos dados obtidos tem relação com a quantidade de tempo que os alunos estudam fora das aulas e, ainda, a sua rotina de estudos descrita por eles mesmos. Inicialmente, quando questionados se estudam ou não em casa, no segundo questionário, de sete participantes desta etapa da pesquisa, apenas um escolhe a opção "não". Além disso, vale ressaltar que apesar de seis alunos afirmarem que estudam em casa, alguns deles escolhem a opção "menos de uma hora por semana". Contudo, mesmo escolhendo essa opção, a descrição da rotina de estudos desses alunos não condiz com o tempo que eles afirmam utilizar para estudar em casa.

Antes de discutir mais sobre esse tema, é necessário ter uma visão geral sobre os respondentes e a quantidade de horas que eles afirmam estudar. Vale ressaltar que os dados da tabela abaixo foram retirados das perguntas, 10 e 11 do segundo questionário:

\begin{tabular}{ccc}
\hline Respondente & Estuda em casa? & Quantidade de tempo \\
\hline A1 & Sim & Menos de 1 hora \\
A2 & Sim & Entre 4 e 6 horas \\
A5 & Sim & Entre 2 e 4 horas \\
A7 & Sim & Entre 2 e 4 horas \\
A10 & Sim & Menos de 1 hora \\
A11 & Sim & Menos de 1 hora \\
A12 & Não & Menos de 1 hora \\
\hline
\end{tabular}

Tabela 13: respostas obtidas nas perguntas 11 e 12 do segundo questionário

Apesar de terem assinalado a mesma quantidade de tempo de estudos, há uma clara divergência em relação às respostas de $A 1, A 10$ e A11, que assinalaram "sim", quando comparadas com a resposta de A12, que assinalou "não". Aqui, notase as respostas obtidas apontam para diferentes julgamentos que os alunos fazem sobre si. A1, A10 e A11, fazem uma avaliação mais branda acerca do seu desempenho nos estudos realizados em casa, ao passo que, A12 é mais severo consigo. 
Sobre a tendência de optar sempre em ser o mais positivo possível, quando questionados acerca da sua rotina de estudos de maneira concreta, é possível constatar que, independente da quantidade de horas que afirmam estudar e, ainda, independente de afirmarem se estudam ou não em casa, a rotina de estudos fornecida pelos respondentes é muito parecida. Nesse sentido, todos afirmam ouvir músicas, procurar vídeos ou utilizar aplicativos de celular para estudar. A pergunta 12 do questionário era a seguinte:

12. Como você estuda em casa? Procure dar exemplos concretos sobre a sua rotina de estudos em relação ao alemão.

Quadro 45: pergunta 12 do segundo questionário

Algumas respostas para esta questão foram as seguintes:

- A1 (estuda em casa menos de 1 hora por semana)

Não obtenho maneiras específicas, pois gosto de um estudo diferenciado, mas sempre estou ouvindo músicas, visualizando sites e vendo vídeos.

- A2 (estuda em casa de 4 a 6 horas por semana)

Eu procuro artigos em alemão, filmes ou vídeos em alemão, mas prefiro ouvir músicas e procurar a tradução ou significado da letra (porém, me sinto mais confortável em fazer exercícios para casa que foram passados em aula, pois consigo relembrar e aprender melhor o conteúdo).

- A5 (estuda em casa de 2 a 4 horas por semana)

Eu assisto vídeos aula, releio o conteúdo dado nas aulas, com músicas etc.

- A7 (estuda em casa de 2 a 4 horas por semana)

Vendo algumas vídeo aulas, falando, escrevendo, fazendo exercícios.

- A11 (estuda menos de 1 hora em casa por semana)

Procuro aplicativos que ajudem a revisar assuntos tratados no curso, procuro sites especializados na língua alemã, vejo as traduções das músicas alemãs, assisto vídeo aulas e reviso a matéria já estudada.

- A12 (não estuda em casa com frequência)

Procuro vídeos, ou acabo pesquisando questões gramaticais. Não sei ainda a melhor forma para se aprender vocabulário. Realizo ou reviso exercícios que tenho em meu caderno e tento aprender novas palavras ouvindo-as.

A partir das falas elencadas acima, fica perceptível que os alunos opinam sobre sua rotina de estudos, mas não levam em consideração a opção que foi marcada nas questões anteriores de modo que, assim como já foi dito, todas elas são muito similares. Contudo, é preciso deixar claro que a resposta fornecida por A2 
deixa implícita a utilização do LD em casa já que o respondente afirma que se sente confortável fazendo lições que são passadas para casa. Porém, neste caso, há mais uma inconsistência observada já que A2 afirma não possuir cópias e nem um exemplar do LD.

Por outro lado, o respondente A12, que afirma possuir versões em PDF do LD, não cita o dispositivo em sua resposta e afirma que utiliza seu caderno para revisar exercícios, no entanto, não se pode deixar de lado que esse respondente marcou a opção afirmando que não costuma estudar em casa.

Desse modo, o panorama que se apresenta indica que os alunos do grupo estudado, apesar de terem contato com outras línguas estrangeiras e apesar de já terem contato com outros LD, não costumam se apropriar desse material para estudar e, além disso, falta a esses alunos desenvolver estratégias concretas para estudar uma vez que seus discursos apontam para a utilização de frases não refletidas provenientes do senso comum sobre como se estudar uma LE. Nesse sentido, os alunos não afirmam que ouvem músicas para identificar e pesquisar novos vocabulários, mas sim para ter algum contato com a língua alemã. Dito de outro modo: falta aos alunos o entendimento sobre como estudar LE já que eles se limitam a encarar seus estudos a usos de aplicativos, ouvir músicas e ver vídeos sem, no entanto, pensar em um contexto e na prática dos elementos que são estudados em aula.

\subsubsection{Incompatibilidade nos discursos: o que é dito e o que acontece}

Nos dados obtidos nota-se uma grande divergência nos discursos proferidos acerca do LD pelos alunos que acarretam com o surgimento da hipótese de que eles não se sentem aptos a criticar ou a propor um LD ideal para eles assim como foi discutido anteriormente.

Cabe ressaltar que tais divergências se observam, sobretudo, quando são confrontadas com perguntas que envolvem escalas e perguntas livres nas quais os alunos podem se manifestar de maneira mais aberta acerca de determinado aspecto que envolve o uso do LD. Nesse sentido, o que se nota é que quando confrontados com uma escala, a tendência é que os alunos optem por sempre fornecer respostas 
com valores elevados, mas que, no momento em que precisam explicar a sua opinião, aparecem em seus discursos informações conflitantes.

Como exemplo dessa divergência no discurso dos alunos em relação à sua visão sobre o LD é possível citar as perguntas 8, 12 e 15 do segundo questionário. A pergunta 8 pedia para que os alunos escolhessem em uma escala o grau de importância de se ter um exemplar ou uma cópia do LD em casa:

8. Em uma escala de 1 a 6 em que 1 representa "pouca importância" e 6 representa "muita importância", qual é, na sua opinião a importância de se ter uma cópia do livro didático em casa.

Pouca importância (1) (2) (3) (4) (5) (6) Muita importância

Quadro 46: pergunta 8 do segundo questionário

Por sua vez, a pergunta 12 pedia para que os alunos fornecessem exemplos concretos acerca da sua rotina de estudos em casa e, por fim, a questão 15 pedia para que eles elencassem de acordo com o grau de importância, os materiais utilizados por eles para estudar em casa:

12. Como você estuda em casa? Procure dar exemplos concretos sobre a sua rotina de estudos em relação ao alemão.

15. Enumere o grau de importância que você atribui aos materiais de estudo usados em casa utilizando os materiais listados na pergunta anterior e outros que você considerar importantes. O número 1 representa o material mais importante e o número 4 , o menos importante.

(1)

(2)

(3)

(4)

Quadro 47perguntas 12 e 15 do segundo questionário

Verificando as respostas, percebe-se que dos sete alunos que participaram desta etapa da coleta de dados, cinco assinalaram o valor mais alto da escala. No entanto, ao verificar as respostas obtidas na questão 12, percebe-se que, apesar de afirmarem a importância do LD, poucos deixaram claro como é a sua utilização para estudos em casa: 


\title{
A1 (marcou 6 na questão 8)
}

Não obtenho maneiras específicas, pois gosto de um estudo diferenciado, mas sempre estou ouvindo músicas, visualizando sites e vendo vídeos.

No caso do respondente $A 1$, assim como se observa na resposta acima, apesar de citar o alto grau de importância do LD, não o cita em sua resposta à questão 12 de modo a deixar implícito o fato de que a opinião expressa na questão 8 não condiz com a sua realidade e, portanto, não representa realmente a importância que o respondente atribui ao LD. Seguindo o mesmo raciocínio, o respondente, ao elencar os materiais utilizados de acordo com o seu grau de importância para o estudo em casa, na questão 15, não coloca o LD em sua lista, a qual contem "1. Listas de palavras/2. Aplicativos/ 3. Sites/4. Vídeos."

Em outros casos, a divergência se apresenta de maneira mais tênue de modo que, mesmo que o respondente não cite claramente o LD na questão 8 , ele deixa implícito na questão 12 que existe o seu uso:

\author{
A7 (marcou 6 na questão 8) \\ Vendo algumas vídeo aulas, falando, escrevendo, fazendo exercícios \\ (questão 12) \\ 1. O livro didático/ 2. Dicionário/ 3. Aplicativo/ 4. Não escreveu nada \\ (questão 15)
}

Neste caso, o respondente marcou o valor mais alto da escala apresentada na pergunta 6 e, apesar de sua resposta ser um tanto quanto vaga ao abordar aspectos como "falando" e "escrevendo", não se pode ignorar o fato de que o aluno escreveu "fazendo exercícios". Desse modo, fica implícito que talvez ele esteja se referindo ao LD para demonstrar uma parte de sua rotina de estudos.

As respostas dos dois alunos corroboram com a visão de que o LD, mesmo sendo elemento norteador do curso e do trajeto de aprendizagem de alemão, não possui a mesma importância para todos os respondentes do grupo pesquisado. Além disso, as divergências observadas nos discursos dos alunos denotam a falta de compreensão acerca de suas próprias necessidades de modo que eles se colocam de forma displicente em relação aos diversos aspectos que cercam o estudo de alemão, incluindo o próprio LD.

Ainda sobre a divergência nos discursos, é necessário suscitar mais uma vez a pergunta apresentada anteriormente sobre a importância de se ter um LD em 
casa, seja um exemplar impresso, ou uma cópia completa ou de algumas unidades. Levando em conta que, cinco dos sete alunos participantes da segunda etapa do questionário assinalaram o valor mais alto da escala, é de esperar que todos possuam e utilizem os seus LD, nas aulas e em casa.

Cruzando as informações obtidas com a pergunta 7 e 8 do segundo questionário, o que se apresenta é o seguinte:

\begin{tabular}{ccc}
\hline Respondente & $\begin{array}{c}\text { Importância de ter um } \\
\text { LD em casa (pergunta 8) }\end{array}$ & $\begin{array}{c}\text { Possuí um exemplar ou } \\
\text { cópia do LD (pergunta 7) }\end{array}$ \\
\hline A1 & 6 & \multicolumn{1}{c}{ Não possui } \\
A2 & 6 & Não possui \\
A5 & 4 & $\begin{array}{c}\text { Não possui } \\
\text { A7 }\end{array}$ \\
& 6 & $\begin{array}{l}\text { Kursbuch em PDF e } \\
\text { impresso. Arbeitsbuch } \\
\text { em PDF e impresso }\end{array}$ \\
A10 & 4 & $\begin{array}{l}\text { Arbeitsbuch em PDF } \\
\text { A11 }\end{array}$ \\
A12 & 6 & $\begin{array}{l}\text { Kursbuch e Arbeitsbuch } \\
\text { impresso } \\
\end{array}$ \\
& 6 & $\begin{array}{l}\text { Kursbuch e Arbeitsbuch } \\
\text { em PDF }\end{array}$ \\
\hline
\end{tabular}

Tabela 14: dados das perguntas 7 e 8 do segundo questionário

Observando a tabela, nota-se a divergência nos discursos de alguns alunos que, por um lado, assinalam a importância de se ter um LD mas que, no entanto, afirmam não ter um exemplar, como é o caso dos respondentes A1, A2 e A5. Por outro lado, há respondentes, como é o caso do A7, que afirma possuir um exemplar impresso e a versão impressa, tanto do Kursbuch, quanto do Arbeitsbuch do livro adotado no curso. Cabe ressaltar que o respondente A7, além de afirmar ter cópias do LD, também afirma que utiliza esse material para estudar em casa, na pergunta 13 do segundo questionário, que pergunta de forma específica o que os alunos usam para estudar em casa.

Outro fato que chama a atenção em relação a esse dado está diretamente relacionado com a rotina da turma analisada já que, apesar de assinalarem um alto valor acerca da importância de se ter o LD e, ainda, mesmo que alguns afirmem 
possuir um exemplar ou uma cópia, durante as aulas nenhum dos alunos levava o seu exemplar do LD ou algum tipo de cópia. Além disso, era comum durante as aulas que os alunos tirassem fotos das páginas do Arbeitsbuch que porventura eram solicitadas como lição de casa.

Dessa forma, além dos dados divergentes, observa-se que há inconsistências em relação ao discurso proferido pelos alunos e a sua prática uma vez que, tendo em vista a situação exposta, não é possível aferir se os alunos realmente possuíam os exemplares ou cópias do LD - assim como constava nas respostas - e, ainda, se as respostas não foram fornecidas de modo a agradar o pesquisador, que no caso também era o professor, ou de forma que eles não precisassem se expor. 


\section{Conclusão}

Esta pesquisa buscava entender quais eram as necessidades dos alunos em relação ao LD utilizado no curso de alemão em uma turma específica de uma unidade do CEL. Para isso, foi necessário entender em que consistiam essas necessidades e qual a sua natureza. Desse modo, primeiramente, os estudos de Richards (2001) se mostraram relevantes já que a partir deles foi possível compreender o que eram necessidades, os propósitos de se realizar uma análise de necessidades e como elas podem ser percebidas. Contudo, vale ressaltar que, apesar de relevante, os estudos de Richards não abordam de forma explícita a perspectiva dos alunos em relação às necessidades de modo que foi necessário suscitar o trabalho de Weissenberg (2012) a fim de que se diferenciasse de forma clara para a pesquisa qual o tipo de necessidade seria o foco de análise.

Para Weissenberg (2012) existem três tipos bem delimitados de necessidades: as necessidades objetivas, as necessidades subjetivas e as necessidades orientadas pelo processo.

Como necessidades objetivas, assim como foi discutido no referencial teórico deste trabalho, classificam-se as necessidades que estão relacionadas com instituições de ensino e legislação. Dessa forma, esse tipo de necessidade está relacionado com o amplo contexto no qual os cursos são abarcados e trata sobre leis e regras de funcionamento dos cursos como: quantidade mínima e máxima de alunos, materiais utilizados, tempo de duração das aulas e espaços a serem utilizados para esse fim. Já as necessidades subjetivas são vistas a partir da perspectiva dos próprios alunos com base nas afirmações deles acerca de diversos temas que fazem parte da rotina dos cursos, como o LD, por exemplo. Como último tipo de necessidade, surgem as necessidades processuais que, por sua vez, são vistas a partir da perspectiva do próprio professor que observa seus alunos durante as aulas. O foco da pesquisa incidiu sobre as necessidades subjetivas e processuais, já que os aspectos acerca do LD foram analisados, primeiramente através do viés dos alunos e, depois, a partir da perspectiva do próprio professor ao observar a turma analisada. 
Uma pilotagem inicial desenvolvida antes da coleta empírica de dados mostrou que os alunos tinham a tendência de fornecer respostas não refletidas acerca do LD utilizado por eles, de modo que tais respostas não ajudariam a chegar a alguma conclusão acerca da opinião deles. Desse modo, a ordem inicial pensada para a coleta foi modificada e, antes da aplicação do questionário para a turma analisada, foi necessário desenvolver atividades que tinham como objetivo promover uma primeira reflexão acerca do LD.

Mesmo com o desenvolvimento das atividades em estações, o que se notou durante a coleta é que os alunos tiveram muita dificuldade em diferenciar a figura do professor e do pesquisador. Dessa forma, mesmo que eles tivessem as instruções bem claras acerca do que deveria ser feito em cada uma das estações, os alunos perguntavam a todo momento se eles estavam fazendo a atividade de forma correta e, além disso, notava-se que mesmo sendo avisados de que aquelas atividades faziam parte de um projeto de pesquisa e que eles não seriam identificados ou avaliados por aquelas respostas, havia um certo receio por parte dos alunos em ser julgados de modo que essa insegurança se verificou em algumas respostas obtidas.

Ao analisar os dados, foi verificado que havia uma tendência por parte dos alunos a fornecer respostas sempre positivas acerca do LD, sobretudo quando confrontados com perguntas que envolviam escalas. Contudo, ao analisar as respostas fornecidas pelos respondentes de forma mais livre, notou-se que nem sempre essa visão positiva fornecida nas perguntas de escala era coerente, uma vez que as afirmações feitas pelos alunos contradiziam a sua resposta anterior. Desse modo, os dados apontam para o fato de que esses alunos possuem pouca experiência em refletir sobre e articular as suas necessidades.

Além disso, notou-se que os alunos possuíam pouca familiaridade com o LD e tinham dificuldades em entender questões como a progressão dos exercícios ou, ainda, a própria organização do dispositivo. Desse modo, surge um aspecto importante que diz respeito ao contato dos alunos com LE: mesmo o alemão não sendo a primeira LE com a qual eles têm contato, assim como revelam os dados, nota-se, a partir do ponto de vista do professor como necessidade processual, que há pouca experiência por parte deles em aprender um idioma. Dito de outra forma, falta nos alunos entender que estudar uma LE depende de um processo e que os 
conteúdos aplicados não podem ser ignorados após as avaliações, por exemplo. Além disso, falta que os alunos percebam que o objetivo dos cursos no CEL é fazer com que eles dominem a língua em diversas competências, entre elas, a fala. Nesse sentido, é preciso deixar claro para estes alunos que não apenas o registro escrito feito por eles e o fato de entender o que se pede nos exercícios é parâmetro para avaliar a aprendizagem de alemão e que é preciso falar e colocar em prática aqueles novos conhecimentos.

Portanto, seria importante ensiná-los estratégias de estudo, por exemplo, já que muitos, além de não conseguirem refletir acerca do LD, afirmaram que não estudam em casa de modo que praticam seus conhecimentos apenas durante as aulas.

Outro fator importante diz respeito ao fato de que os alunos do grupo estudado, apesar de terem informado no questionário que possuem exemplares ou cópias do LD, não os trazem para a aula e, quando questionados acerca de lições de casa não feitos, a falta do LD era um argumento frequente. Desse modo, nota-se que há, por um lado, a comodidade dos alunos em saber que os livros estão disponíveis na escola para que eles possam utiliza-los durante as aulas e, por outro, uma divergência entre pensamento e prática já que esses mesmos alunos atribuem uma importância elevada ao dispositivo sem, no entanto, querer adquiri-lo. Assim, o panorama que se forma apresenta alunos que, apesar de acreditarem que o LD é um elemento importante para o seu processo de aprendizagem de alemão, não se apropriam desse dispositivo para seus estudos, seja durante as aulas, seja para os estudos em casa.

Quanto às expectativas dos alunos em relação ao LD, alvo da primeira pergunta norteadora deste trabalho, nota-se que existe no imaginário dos alunos um LD genérico que abarca todas as características comuns de um LD disponível no mercado. Dito de outra maneira: os alunos buscam um LD que seja organizado, que traga resumos e que possua um design interessante.

Desse modo, o que se observa é que a não apropriação do LD por parte dos alunos gere uma falsa satisfação em relação ao que eles já têm disponível e, assim, fica difícil para eles imaginarem o que esperar desse dispositivo. Além disso, vale ressaltar que a presença do LD no contexto analisado não é discutida amplamente 
no âmbito da escola que abrigou a pesquisa, de modo que tal presença é vista pelos alunos como algo natural ou, ainda, inquestionável e, por isso, existe a dificuldade observada em analisar e refletir acerca do LD utilizado uma vez que, para os alunos, o dispositivo é uma ferramenta que estará disponível e que será utilizada durante as aulas independente de discussões ou da opinião deles acerca da relevância desse material para o curso.

Quanto à segunda pergunta de pesquisa, que trata sobre a quantidade de livros disponíveis afetar o processo de aprendizagem dos alunos, nota-se que, por um lado, eles reconhecem a importância do dispositivo para as aulas e afirmam que, caso haja uma quantidade inferior à quantidade de alunos, isso afetará de forma negativa o processo de aprendizagem. Ao tratar sobre esse aspecto, os alunos elencam uma série de fatores negativos em relação à ausência parcial do dispositivo: quando há menos LD do que a quantidade de alunos, existe o fator da vergonha entre alunos que se acanham e precisam utilizar o LD juntos durante a aula, usando o LD juntos não é possível personalizar as anotações e, ainda, é preciso respeitar o tempo do colega que talvez demore mais para realizar determinada atividade. Por outro lado, apesar dessas informações, os dados corroboram para a análise de que os alunos não atribuem a importância mencionada por eles ao LD uma vez que eles não possuem exemplares ou cópias do mesmo, tanto para o estudo durante as aulas, quanto para seus estudos individuais, em casa.

Dessa forma, nota-se que o LD para esses alunos representa um dispositivo que faz parte da aula, mas que não thes cabe discutir acerca de seus pontos positivos e de suas deficiências tendo em vista que eles não se apropriam verdadeiramente dessa ferramenta para seus estudos. Visto de forma mais ampla, os alunos parecem se colocar em uma posição de extrema aceitação em relação ao seu processo de aprendizagem de alemão, de modo que, para eles, tratar acerca da estrutura do curso ou do próprio LD não é algo importante já que a sua opinião não vai ser ouvida ou não vai gerar nenhuma mudança significativa.

Além disso, a ausência do dispositivo, que é vista de forma negativa pela maioria dos alunos, apresenta uma série de questões que precisam ser observadas. Primeiramente, essa ausência em aula poderia ser explicada pelo fato da língua 
alemã não ser parte do PNLD e, ainda, pelo fato de que a escola não pode colocar a aquisição do LD como requisito para frequentar o curso. Dessa forma, quando as turmas são numerosas, é preciso que sejam feitas adaptações a partir dos LD disponíveis e estimular os alunos a adquirir seus próprios exemplares ou cópias. Por outro lado, mesmo que a ausência desse dispositivo acarrete em malefícios para a aula, parece que os alunos não entendem que o LD é um material feito para ser utilizado durante todo o processo de aprendizagem e que seu uso não se restringe aos limites da sala de aula. Nesse sentido, ao verificar que muitos alunos refutam o uso desse material em casa, há a confirmação de que eles ainda não são capazes de notar o verdadeiro papel do LD durante o processo de aprendizagem de alemão. Dessa forma, seria importante discutir e mostrar a eles os usos que se pode fazer acerca desse dispositivo e da importância que ele exerce.

Por fim, vale ressaltar que para pesquisas futuras seria viável analisar qual é a visão ampla desses alunos no contexto dos CEL acerca do estudo de LE e quais são os fatores do ensino regular que influenciam diretamente nessa visão assim como, por exemplo, o fato de não acharem importante adquirir LD para estudar em casa já que a escola oferece esse material para uso durante as aulas, assim como ocorre nas demais disciplinas. Além disso, cabe ressaltar que na escola que abrigou a pesquisa existe a oferta do ensino médio em período integral e que é comum ouvir da equipe gestora da escola que os alunos devem ser protagonistas em seu processo de aprendizagem. Contudo, levando em conta que grande parte dos alunos do CEL pesquisado é proveniente do ensino integral, caberia investigar os motivos que os leva a não encarar esse protagonismo também no âmbito dos cursos do CEL, já que estes são oferecidos nas dependências de uma mesma escola. 


\section{Referências Bibliográficas}

AGUADO, K. Triangulation. In: Settinieri, J.; Demirkaya, S.; Feldmeier, A.; (et al.). Empirsiche Forschungsmethoden für Deutsch als Fremd- und Zweitsprache. Eine Einführung. Ferdnand Schöningh, 2015.

BIMMEL, P.; KAST, B.; NEUNER, G. Deutschunterricht planen neu. Berlin et al.: Langenscheidt, 2011. (=Fernstudieneinheit 18; edição reformulada)

BOHUNOVSKY, R. A escolha de um livro didático internacional para o contexto brasileiro: estabelecer e adaptar os critérios de avaliação. In: Revista X, Volume 2, 2009, p. 22-38.

da UFPR, 2011.

Ensinar alemão no Brasil: Contextos e Conteúdos. Curitiba. Editora

BORTONI-RICARDO, S. M.. O professor pesquisador: Introdução à pesquisa qualitativa. 1. ed. São Paulo: Parábola, 2008.

BRASIL. MEC. Parâmetros Curriculares Nacionais. (5 a $8^{\underline{a}}$ séries) Brasília: MEC/SEF, 1998. 10 volumes.

MEC. Orientações Curriculares para o Ensino Médio. Ciências Humanas e suas tecnologias. Brasília: SEB, 2006.

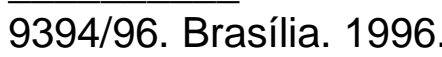

Senado Federal. Lei de Diretrizes e Bases da Educação Nacional:

BREITUNG, H.; LATTARO, E. Regionale Lehrwerke und Lehrmethoden. In: HELBIG, Gerhard et al. (Orgs.). Deutsch als Fremdsprache. Ein internationales Handbuch, v. 2. Berlin / New York: de Gruyter, 2001, p. 1041-1053.

BRINDLEY, G. Needs analysis and objective setting in the adult immigrant education program. Sydney: N. S. W. Adult Immigration Education Service, 1984.

CHECCETTO, M.A.D: 'Freiarbeit' ('Aula Livre') e o ensino-aprendizagem do 'Perfekt': uma experiência pedagógica com aprendizes brasileiros do alemão com língua estrangeira. Dissertação (mestrado), Faculdade de Filosofia, Letras e Ciências Humanas, Universidade de São Paulo, 2002.

CELANI, M.A.A. O ensino de línguas estrangeiras: ocupação ou profissão. In: LEFFA, V. (Org.) O professor de línguas estrangeiras: Construindo a profissão. Pelotas: Educat/ ALAB, 2001, p. 21-37.

CONSELHO DA EUROPA. Quadro Europeu Comum de Referência para as Línguas - Aprendizagem, ensino, avaliação. Porto: Edições ASA, 2001. 
DENZIN, N. K. The research act. Chicaco: Aldine, 1970.

DÖRNYEI, Z. Questionnaires in second language research. Construction, Administration and Processing. Mahwah, New Jersey, 2003.

DUTRA, M. C. D. 0 ensino de estratégias de aprendizagem e o desenvolvimento da autonomia do aprendiz de alemão em turmas multisseriadas de escolas públicas do Estado de São Paulo. 2016. Dissertação (mestrado) - Faculdade de Filosofia, Letras e Ciências Humanas da Universidade de São Paulo, 2016.

EVANGELISTA, M. C. R. Die Deutschlehrerausbildung an brasilianischen Universitäten: Neue Erkenntnisse? In: Anais do $8^{\circ}$ congresso brasileiro de professores de alemão. Belo Horizonte: ABRAPA, 2011. Disponível em: http://abrapa.org.br/hotsite/pdf/Arquivo019.pdf (consultado em 26.05.2015)

FERRARI, B. A influência do inglês no processo de ensino/aprendizagem de alemão por aprendizes brasileiros de terceiras línguas: abordagens e métodos de investigação. In: Pandaemonium, v. 17, n. 24. São Paulo, 2014, p. 175-197.

FLICK, U. Qualitative Sozialforschung. Eine Einführung. Reinbek: Rowohlt, 2009.

FUNK, H. Das Ende ist nah! Oder auch nicht. Zum Funktionswandel der Fremdsprachenlehrwerke. In: ; KOENIG, M. (Orgs.). Kommunikative Fremdsprachendidaktik. Theorie und Praxis in Deutsch als Fremdsprache. Festschrift für Gerhard Neuner zum 60. Geburtstag. München: ludicium, 2001, p. 279-293.

. Qualitätsmerkmale von Lehrwerken prüfen - ein Verfahrensvorschlag. In: Babylonia N3, 2004. P. 41-47.

GODOY, L. P. M. Juntar ou separar? Reflexões sobre o contexto multisserial de ensino de Francês como Língua Estrangeira nos Centros de Estudos de Línguas/ Lilian Paula Martins Godoy; orientação: Vera Lúcia Marinelli. São Paulo: s.n., 2013.

GONSALVES, E. P. Conversas sobre iniciação à pesquisa científica. $4^{\underline{a}}$ ed. Campinas: Alínea, 2007.

GUDJONS, H. Habdlungsorientiert lehren und lernen. Schüleraktivierung, Selbstttätigkeit, Projektarbeit. 7. Auflage, Klinkhardt, 2008.

KOPP, G.; BÜTTNER, S. Planet 1 - Deutsch für Jugendliche. Kursbuch. Ismaning: Editora Hueber, 2004.

LEFFA, V. J. O ensino de línguas estrangeiras no contexto nacional. Contexturas, APLIESP, n. 4, p. 13-24, 1999. 
MAIJALA, M. Was ein Lehrwerk können muss - Theses und Empfehlungen zu Potenzielen und Grenzen des Lehrwerks im Unterricht Deutsch als Fremdsprache. In: Info DaF 34, 6, 2007, p. 543-561.

NEUNER, G. (Org.); KURSISA, A.; PILYPAITYTE, L.; SZAKALY, E.; VICENTE, S. Deutsch.com 1. Ismaning: Editora Hueber, 2008.

Lehrmaterialforschung und -entwicklung. Zentrale Bereiche der Theorie und Praxis des Fremdsprachenunterrichts. In: BAUSCH, Karl-Heinz et al. (Orgs.). Die Erforschung von Lehr- und Lernmaterialien im Kontext des Lehrens und Lernens fremder Sprachen. Tübingen: Narr, 1999, p. 158-167.

MAYER, R. Do monolingüismo ao plurilingüismo nas escolas públicas de $1^{\circ}$ e $2^{\circ}$ graus. In: Associação Paulista de Professores de Alemão (org.).Manual de Informações para o Professor de Alemão. Handbuch für den Deutschlehrer. São Paulo: APPA, 1989, p. 6-13.

PAIVA, V. L. M. de Oliveira e. A LDB e a legislação vigente sobre o ensino e a formação de professor de língua inglesa. In: Stevens, Cristina Maria Teixeira; Cunha, Maria Jandyra Cavalcanti (orgs.). Caminhos e colheita. Ensino e pesquisa na área de inglês o Brasil. Brasília: Editora Universidade de Brasília, 2003, p. 53-84.

PEUSCHEL, K. Curriculumentwicklung für spezifische Zwecke - Szenarien für die Sprachausbildung im Germanistikstudium. In: HERZIG, K.; PFLEGER, S.; SPINASSÉ, K.P.; SADOWSKI, S. (Org). Transformationen: DaF-Didaktik in Leteinamerika. Impulse aus Forschung und Unterrichstspraxis. Associação Latino-americana de Estudos Germanísticos, vol. 4, 2008, p. 31-42.

RICHARDS, J. C. Needs analysis. In: Curriculum Development in Language Teaching. Cambridge University Press, 2001.

RÖSLER, D. Deutsch als Fremdsprache. Eine Einführung. Stuttgart: Metzler, 2012

; WÜRFFEL, N. Deutsch Lehren Lernen 5: Lernmaterialien und Medien. 1. ed. München: Langenscheid Klett, 2014

SÃO PAULO (Estado). Secretaria da Educação. Resolução SE n 193 de 18 de agosto de 1988. Dá uma nova redação ao parágrafo único do artigo $1^{\circ}$ da Resolução SE n²71/87. São Paulo, 1988.

Resolução SE n $^{\circ} 271$ de 20 de novembro de 1987. Dispõe sobre o funcionamento e as atividades dos Centros de Estudos de Línguas do Estado de São Paulo. São Paulo, 1987. 
Decreto $n^{\circ}$ 27,270, de 10 de agosto de 1987. Dispõe sobre a regulamentação e criação dos Centros de Estudos de Línguas do Estado de São Paulo. São Paulo, 1987.

SILVEIRA, R. O livro didático de alemão como língua estrangeira na universidade: reflexões a partir de uma sondagem. In: Anais do $1^{\circ}$ congresso da Associação Brasileira de Estudos Germanísticos. São Paulo: ABEG, 2016. Disponível em: http://germanistik-brasil.org.br/wp-content/uploads/2016/05/Silveira-O-livrodid\%C3\%A1tico-nas-aulas-de-alem\%C3\%A3o-como-1\%C3\%ADngua-estrangeira-nauniversidade.pdf

SOUZA, D. M. E o livro didático não anda, professor? In: CORACINI, M.J. O jogo discursivo na sala de leitura - língua materna e língua estrangeira. Campinas: Pontes, 1995, p. $119-122$.

STEVENS, C. M. T.; CUNHA, M. J. C. (Org.). Caminhos e Colheita: Ensino e pesquisa na área de inglês no Brasil. Brasília: Editora UnB, 2003.

TOMLINSON, Brian. Glossary of basic terms for materials development in language teaching. In: (Org.). Materials development in language teaching. Cambridge: Cambridge University Press, 2011, p. ix-xviii.

UPHOFF, D. O poder do livro didático e a posição do professor no ensino de alemão como língua estrangeira. Tese de doutorado apresentada ao Departamento de linguística Aplicada, Instituto de Estudos da Linguagem, Unicamp, 2009.

DEBIA, D. T. O papel do ensino de língua e a passagem para as disciplinas de literatura no curso de Letras-Alemão da USP: considerações a partir de uma análise de necessidades. In: UPHOFF, D. et al. (Orgs.). O Ensino de Alemão em contexto universitário: modalidades, desafios e perspectivas. São Paulo: Humanitas, 2017: 169-190.

ZENTRALSTELLE FÜR DAS AUSLANDSSCHULWESEN (ZfA). Rahmenplan "Deutsch als Fremdsprache" für das Auslandsschulwesen. Köln: Bundesverwaltungsamt, 2009.

WEISSENBERG, J. Sprachbedarfsermittlung im Berufsbezogenen Unterricht Deutsch als Zweitesprache. Hamburg: Passage, 2012. Disponível em: $<$ http://www.deutsch-amarbeitsplatz.de/fileadmin/user_upload/PDF/BD_Fachstelle_Brosch\%C3\%BCre_2012 _A4_web.pdf> (Acesso em 20/07/2016) 


\title{
Anexos
}

\section{Anexo A - Termo de consentimento}

\section{UNIVERSIDADE DE SÃO PAULO \\ FACULDADE DE FILOSOFIA, LETRAS E CIÊNCIAS HUMANAS \\ Departamento de Letras Modernas}

\begin{abstract}
Av. Prof. Luciano Gualberto, 403 - CEP $05508-010$ - Cidade Universitária - São Paulo - SP. Tel.: (11) 3091-5041 / 3091-4503 / Fax (11) 3032-2325 / e-mail: flm@usp.br

Programa de Pós-Graduação em Língua e Literatura Alemã
\end{abstract}

\section{TERMO DE CONSENTIMENTO DE PARTICIPAÇÃO EM PESQUISA}

Concordo que meu filho/minha filha participe, como voluntário/a, do projeto de pesquisa intitulado $O$ livro didático no processo de ensinoaprendizagem de alemão nos CEL: um estudo de caso, que tem como pesquisador responsável o mestrando Raphael da Silveira, do programa de pós-graduação em Língua e Literatura Alemã do Departamento de Letras Modernas da Faculdade de Filosofia, Letras e Ciências Humanas da Universidade de São Paulo, sob orientação da Dra. Dörthe Uphoff.

A pesquisa tem por objetivo realizar uma análise das necessidades subjetivas dos alunos de um Centro de Estudo de Línguas (CEL) por meio de questionários e atividades didáticas, consistindo minha participação em ceder os materiais por mim produzidos durante a aula da turma 2A no dia 29 de março de 2017.

Compreendo que este estudo possui finalidade de pesquisa e que os dados obtidos serão divulgados seguindo suas diretrizes éticas, com a preservação do anonimato dos participantes, assegurando, assim, a privacidade do meu filho/minha filha. Sei que podemos abandonar a participação na pesquisa quando quisermos e que não receberemos nenhum pagamento por esta participação.

Nome e assinatura

São Paulo, de março de 2017. 


\section{Anexo B - Estações e respostas da primeira etapa da coleta de dados}

\section{Estação 1: Aufbau des Kursbuchs}

Material:

\section{Kursbücher sobre a mesa.}

Instruções:

1. Observem o índice do Kursbuch da lição 17 até a 20 e tentem entender como o livro foi desenvolvido. Respondam as questões abaixo:

a. Como cada uma das lições se organiza? Existe alguma ordem?

b. A qual lição pertencem as páginas 29 a 32 ("Zum Schluss")

c. Para que vocês acham que serve a página 5 ?

2. Na página 5 se encontram os objetivos de aprendizagem da lição 17 a 20 . Comparem essa pagina com o índice, analisem os objetivos descritos nessa página e reflitam: Todos os objetivos coincidem com o que está no índice? Falta alguma coisa? - escrevam suas conclusões na folha blanca.

3. Caso vocês ainda tenham tempo: comparem os módulos do índice e reflitam: todos eles são construídos de maneira parecida? Por que isso acontece? Vocês acham que os capítulos têm relação com o tema dos módulos? - utilizem a folha verde para escrever suas conclusões.

\section{Transcrições das respostas}

\section{Respondentes A2 e A5}

1. a. As lições se organizam primeiro em comunicação, depois vocabulário e por fim gramática.

b. Pertence à lição 18 - Wer Gewinnt?

c. Para dar uma breve introdução do primeiro tema do livro.

2. Ambas as páginas informam o que o livro apresentará, porém, a página 5 apresenta imagens e os assuntos em tópicos, no índice são separados por páginas. Na página 5, está apenas o assunto inicial do livro, já o índice trata do livro todo.

3. Não fizeram 


\section{Respondentes A7 e A14}

1. a. É organizada por cores, imagens.

b. Pertencem a Sport "FuBball".

c. Serve para falar sobre o que virá nas Lektion a seguir.

2. A página 5 passa a base sobre o que vai se passar já no índice fala tudo.

3. Todos eles são construídos de maneira parecida. Acho que ocorre porque é uma maneira mais fácil de aprender. Sim, os capítulos têm relações com os temas dos módulos.

\section{Respondentes A10 e A13}

1. a. Estern*, Neue Worten, Zweiten, Verben und endlich, Fragen.

b. Lektion 18 (archtzehn)

c. (não fizeram)

2. Não fizeram

3. Não fizeram

\section{Respondentes A11 e A12}

1. a. O livro foi desenvolvido para formar o nível de aprendizado de cada capítulo, passando por etapas como a apresentação do assunto sempre sendo explicados com algo do cotidiano, em seguida surgem os novos vocabulários e exemplos logo uma atividade dinâmica para finalmente chegar a exercícios de gramática para que 0 assunto se fixe e também faz facilita 0 entendimento. No final, tudo é revisto a partir dos verbos e vocabulários.

b. Pertence a todas as Lektions, da parte verde, desde o 17 até o 20, como uma retomada ao conteúdo.

c. Ele é como um índice do capítulo ao qual irá ser abordado, com tópicos para melhor explicar o conteúdo. 
2. No índice se tem um geral da divisão entre as áreas que serão estudadas como vocabulário, gramática e comunicação. Já a página que antecede as "Lektions" o assunto é dividido apenas em tópicos, porém ambos se completam não deixando nada em débito.

3. Sim, todos seguem um padrão para apresentar e ensinar o conteúdo ao qual será abordado. Isso acontece para que os alunos não se percam e para que a compreensão seja mais fácil ao aprendizado. Há de se ter reação, já que se assim não fosse, seria uma contradição e por assim dizer não faria sentido.

\section{Estação 2: Tipps uns Strategien im Kursbuch}

Material impresso:

Lektion 17:

Strategie, p. 7: "Bildinformationen helfen dir, die gehörten Informationen zu verstehen."

Tipp, p. 9: "Lern Verben immer mit der Perfektform."

Lektion 18:

Strategie, p. 12: "Lies vor dem Hören die Angaben. Das erleichtert das Verstehen von Einzelinformationen."

Tipp, p. 14: "Finde die Grammatikregel selbst. Lern Ausnahmen auswendig."

Instruções:

1. Em quase toda lição do Kursbuch do livro "Planet" há informações como "Strategien" e "Tipps". Observem essas informações das lições 17 e 18 e traduza-as para o português. Depois disso vocês podem comparar a sua tradução com a que está dentro do envelope na mesa.

2. As "Tipps" e "Strategien" precisam ajudar o aluno a aprender o conteúdo das lições. Formulem outro "Tipp" e outra "Strategie". Usem para isso a folha amarela.

3. Caso vocês ainda tenham tempo: discutam qual poderia ser a principal diferença entre "Tipp" e "Strategie". Escrevam as conclusões na folha verde. 
Transcrição das respostas.

\section{Respondentes A2 e A5}

1.

Lektion 17:

Strategie, p. 7: Informações por imagem ajudam ouvir as informações para compreender.

Tipp, p.9: Aprenda verbos sempre com a forma perfeita

Lektion 18:

Strategie, p. 12: Ler para ouvir as informações. Facilitar a compreensão para informações individuais

Tipp, p. 14: Ache a regra gramatical por si só. Saiba as exceções de cor.

2. Strategie: Compreender um verbo ajuda a entender a frase.

Tipp: Identificar o tempo do verbo para não errar a frase.

3. Não fizeram

Respondentes A7 e A14

1. Não fizeram

2. STRATEGIEN

"Exercicios ajudam a ter um desenvolvimento melhor"

TIPPS

"Sempre lembrar das conjugações" 
3. Strategien: a Strategien é uma lógica você acaba seguindo uma lógica Tipp: A tipp quando eles ou alguém oferece uma dica uma opção para resolver o problema.

\section{Respondentes A10 e A13}

1. TIPP! Aprenda com o verbo sempre no passado perfeito

STRATEGIE: As informações mostradas vão ajudar você, é necessário ouvi-las para compreender.

TIPP! Procure as exceções das regras gramaticais e as decore

STRATEGIE: Ajudar a compreender as informações detalhadamente.

2. TIPP:

"Analise se há semelhanças entre singular e plural, pronome e aos outros gêneros, para não cometer erros".

STRATEGIEN:

"Atente-se para com as regras gramaticais e sobretudo na interpretação dos exercícios".

3. Não fizeram

Respondentes A11 e A12

1.

Lição 17 
Estratégia, p.7: "Informações impressas Ihe ajudam,

Dica, p. 9: "Aprenda verbos sempre na forma perfeita".

\section{Lição 18}

Estratégia, p.12: (em branco)

Dica, p. 14: "Encontre a demonstração de regras gramaticais, e selecione exceções"

2.

Tipp: “Aus, bei, mit, Von, zu und gegenüber, mit dativ, immer"

Estratégia: " tente procurar por verbos em textos, e compreendê-los"

3. Não fizeram

\section{Estação 3: Aktivitäten im Arbeitsbuch}

Material impresso:

P. 9, Nr. 8 "Ergänze”

p. 11, Nr 5 "Schreib Sätze”

p. 17, Nr 7 “Logical”

p. 27, Nr 27 "Wortliste Lektion 17 und 18"

Instruções:

1. Observem os quatro exercícios impressos do "Arbeitsbuch" do livro "Planet 2" e discutam: o precisa ser feito aqui? Escrevam uma instrução em português para cada uma das atividades e comparem com o modelo no envelope que está na mesa.

2. Discutam em grupo o que se aprende em cada uma das quatro atividades. Anotem suas conclusões na folha azul. 
3. Caso vocês tenham tempo: discutam - de quais atividades vocês gostam mais? E de quais vocês não gostam e por quê? Procure explicar a sua opinião. Utilize a folha verde.

\section{Materiais disponíveis}

Página 9

8. Ergänze.

\begin{tabular}{l|l|l}
\hline Max, & Paul und Paula, & Herr Roth, \\
\hline komm doch mal! & & \\
\hline & & helfen Sie mir bitte! \\
\hline & macht mal auf! & \\
\hline zeig mal! &. & holen Sie das bitte! \\
\hline & & \\
\hline & nehmt das Buch! & \\
\hline & & sehen Sie mal! \\
\hline
\end{tabular}

Página 11

5. Schreib Sätze.

1 Jakob:
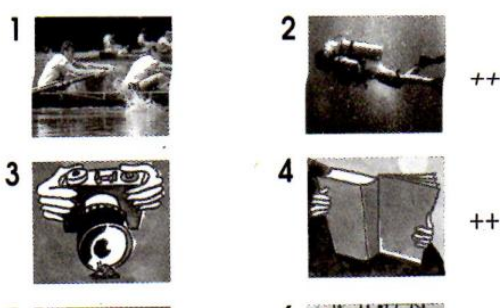

2 Sofia:

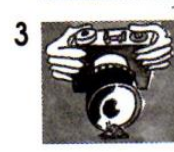

$++$

A

3 Hakan: ++

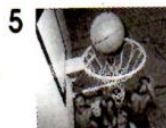

6

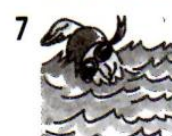

8

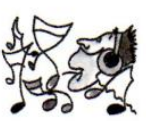

9

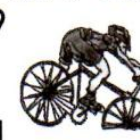

$+++$
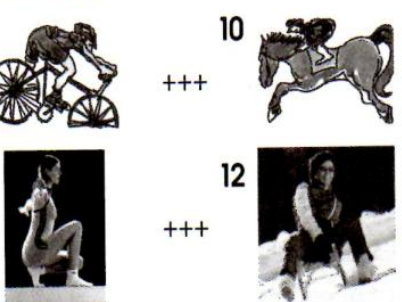

6 Vera: +

12

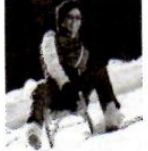

Sätze 1-3: Was macht Jakob/Sofia/Hakan/

... lieber, ... oder ...?

Sätze 4-6: AnnalJosef/Veral... gern, aber am liebsten ... sieler. 


\section{Página 17}

\section{Logical}

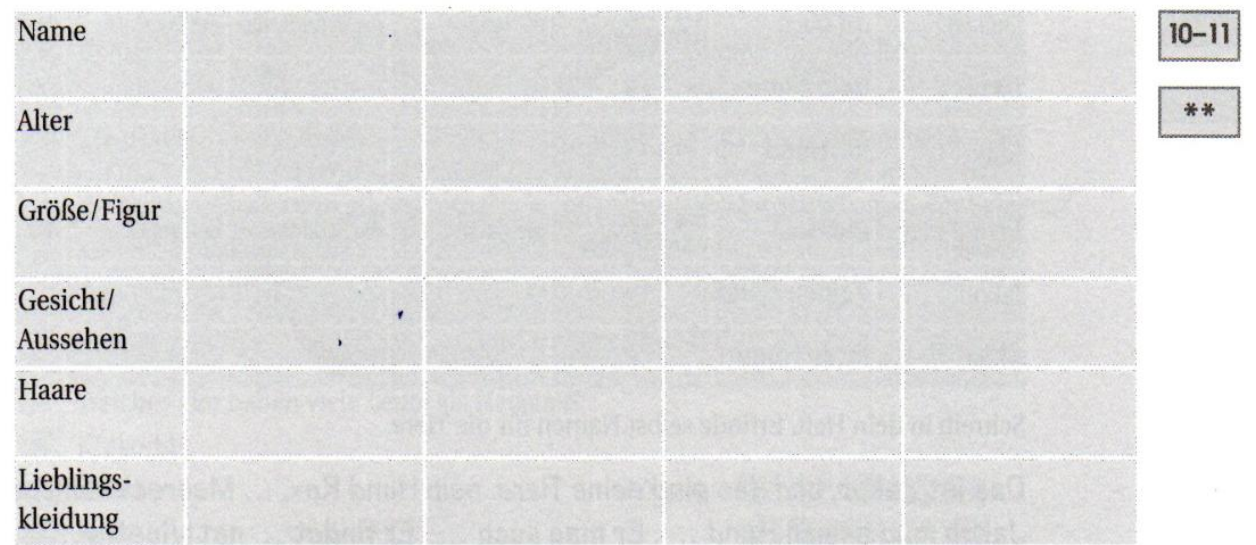

1. Rebecca ist vierzehn Jahre alt.

2. Thomas ist groß und schlank.

3. Maria ist klein. Ihre Haare sind schwarz.

4. Sebastian ist dreizehn Jahre alt. Seine Lieblingskleidung sind Jeans und Pulli.

5. Sie ist fünfzehn.

6. Ihre Haare sind braun.

7. Er ist klein und ein bisschen dick. Seine Nase ist klein, seine Augen sind blau.

8. Sie ist ziemlich groß. Sie trägt am liebsten Rock und Bluse.

9. Ihre Nase ist klein, aber ihr Mund ist groß. Ihre Lieblingskleidung sind Hose und Jacke.

10. Seine Haare sind schwarz. Sein Mund ist groß, seine Ohren auch.

11. Ihre Augen sind grau.

12. Seine Haare sind rot.

Wer ist sechzehn Jahre alt und trägt am liebsten T-Shirts? 
Página 27

\section{Wortliste Lektion 17 und 18}

Markiere die Nomen
mit Farben:
$(\mathrm{m}) \rightarrow$ blau
$(\mathrm{n}) \rightarrow$ grün
$(\mathrm{f}) \rightarrow$ rot

\section{Lektion 17}

Seite 6

Jugendherberge (f), - $n$

Raum (m), "e

Einzelzimmer, das, -

drinnen

draußen

Wald (m), "er

Straße (f), -n

Terrasse (f) - $n$

Garten (m), "en

Wiese (f), -n

See $(m),-n$

Boot (n), -e

Seite 7

zuhören

geben

es gibt

Text

unten

Keller (m), -

Schlafzimmer (n), -

Küche (f), -n

links

hinten

oben

Stock (m), Stockwerke

Klassenzimmer, (m), -

rechts

Seite 8

Bett (n), -en

helfen

allein

So weit kommt's noch!

zeigen

Dialog (m), -e

aufmachen

Fenster (n), -

zumachen.

Tür (f), -en

Schrank (m), "e

stellen

Stuhl (m), "e

Tisch (m), -e

\section{Seite 9}

Hausordnung (f), -en

Titel (m), -

beobachten

Hausschuh (m),-e

abstellen

sorgen für

Abfall (m), "e

genau

decken

abräumen

auf

Baum (m), "e

klettern

Feuer (n), -

Lektion 18

Seite 10

gemein

Angst (f), :e

Treppe (f), -n

vorn

Streit (m) (Sg.)

oblem (n), -

Teil (m), -e

Rudern (n) (Sg.)

Rodeln (n) (Sg.)

Schlitten fahren (n) (Sg.)

Tischtennis (n) (Sg.)

Tauchen (n) (Sg.)

Turnen (n) (Sg.)

Leichtathletik (f) (Sg.)

Werfen (n) (Sg.)

Seite 12

trainieren

schnell

hoch

springen

bestimmt

als

vielleicht

besser

Training (n) (Sg.)

weit

Seite 13

warten

noch

bestehen aus

zurück

wie

wechseln

Wettbewerb (m), -e

vorschlagen

fehlen

Fall (m), "e

auf jeden Fall

fertig

Seite 14

langsam

starten

wenden

fallen

Durst (m) (Sg.)

dabei

ankommen

Situation (f), -en

gratulieren

verlieren

gewinnen

Gespräch (n), -e 


\section{Respostas do envelope que estava sobre a mesa}

\section{Página 9 - exercício 8}

Para cada coluna, observe primeiramente a forma na qual os verbos devem ser colocados (Du, Ihr ou Sie) e complete as linhas seguindo os exemplos.

\section{Página 11 - exercício 5}

Observe os nomes dados pelo exercício e as respectivas figuras que representam ações. De acordo com os sinais (+) escreva frases utilizando GERN e LIEBER para os três primeiros nomes e GERN e AM LIEBSTEN para os três últimos nomes.

\section{Página 17 - exercício 7}

Leia atentamente as instruções, anote primeiro os nomes em cada uma das colunas e, de acordo com as dicas, descubra quem tem 16 anos e prefere usar camisetas.

\section{Página 27 - Wortliste}

Marque cada uma das palavras com a cor correspondente na legenda de acordo com o gênero das palavras.

\section{Transcrição das respostas}

\section{Respondentes A2 e A5}

1. No exercício 5 precisa-se descobrir o que cada um faz e o que mais gosta de fazer.

O exercício 7 pede para identificar os dados de cada pessoa.

Nas lições 17 e 18, temos que ligar os lugares com as cores e as outras palavras da folha.

2. $\mathrm{Na}$ atividade 5 se aprende sobre (palavra ilegível), na atividade 7 sobre as qualidades das pessoas citadas. A atividade 9 serve para organizar as 
terminações dos verbos de acordo com a pessoa. As lições 17 e 18 servem para relacionar as palavras com as cores e com as demais palavras da folha.

3. Nós gostamos mais da atividade 5 pois ela fala de hobbys e é mais fácil do que as outras. A que menos gostamos foi a atividade 17 und 18, pois demoramos pra entender e tava mais difícil que as outras atividades.

\section{Respondentes A7 e A14}

1. P.9

Ex. 8= Observar a forma de como os verbos são colocados e preencher as lacunas

p. 11 ex. $5=($ em branco $)$

p.17 ex. 17 = Completar $\mathrm{o}$ documento de acordo com as frases encontradas abaixo dele

p. $27-$ Wortliste $=$ Diferenciar cada palavra de acordo com o seu gênero

2. Aprende a organizar os verbos, a entender e interpretar o que representa uma imagem.

3. Não fizeram

\section{Respondentes A10 e A13}

1. Conjugar os verbos de acordo com o pronome.

05 - no exercício cinco descreva o que eles (Jakob/ Sophia/ Hakan) mais gostam de fazer ". (Anna/ Josef/ Veral) Agora descreva o que eles mais gostam de fazer.

7 - na questão 7 responda quem tem 17 anos de idade e gosta de vestir camisetas, para tal utilize-se da lógica. 
p. 27 - (não fizeram)

2. Na segunda aprende-se sobre o que gostamos de fazer no tempo livre, já na questão 7 na qual precisa-se de lógica para responder aprende-se sobre organização de informações e interpretação.

3. Gostamos mais das atividades que precisa de lógica, pois precisamos de mais atenção para resolvê-las. Atividades de leitura, escrita e áudio pois nos ajuda a desenvolver melhor o conteúdo que estamos aprendendo e fixa a informação.

Caça - palavras e cruzadinha acaba sendo uma atividade meio boba.

\section{Respondentes A11 e A12}

1. P.9 - Completar a tabela, de acordo com a formalidade e/ou informalidade, e em como a frase se adapta a estas mudanças.

p.11- formar frases de acordo com as imagens de acordo com as imagens apresentadas sobre hobbys, em que se designa sua preferência, e o quão lhe é agradável e/ou seu gosto.

p. 17- de acordo com as frases há de se preencher o formulário com as características de cada pessoa. A combinação necessita de sentido de acordo com o formulário, lógico.

p. 27- são palavras, aos quais estão explícitas os gêneros, no singular e/ou plural, com um vocabulário das lições 17 e 18.

2. P. 11- se aprende como definir preferências de acordo com seus "hobbys", ou seja, atividades "normalmente" realizadas, como também um pouco de vocabulário.

p. 17- busca-se aprender as definições de características de uma pessoa, de uma bem definida para que não haja confusão.

p. 27 - é uma revisão que busca revisar todo o vocabulário aprendido, visando a fixação.

p. 9- aprender as formulações de frase de acordo com os pronomes pessoais, analisando como flexionar o verbo em diferentes pessoas. 
3. Da atividade da página 11, ela retrata a formulação da frase com os hobbys e em qual se deve sua preferência de gosto.

A menos atraente ao meu ver, foi a da p.17, não por ser complexa, mas por ser cansativa e repetitiva.

A10- Gostei muito da atividade "P11" pois incentiva a formar frases que não envolvem apenas verbos e sujeito, mas sim possibilita a formação de frases mais complexas.

A atividade "P17" exige interpretação mas não exige tais no formulário, o que faz com que a mesma fique confusa.

\section{Estação 4: Lernkontrolle und Selbstevaluation}

Material impresso:

Kursbuch, pagina 15: "Das kann ich schon"

Kursbuch, p. 28: "Das kann ich schon"

Arbeitsbuch, p. 24: "Das hast du gelernt"

Arbeitsbuch, p. 25: "Grammatik"

Instruções:

1. Observem as páginas impressas do Kursbuch e do Arbeitsbuch e tentem fazer os exercícios do Arbeitsbuch. Vocês encontrarão as respostas no envelope que está na mesa.

2. Reflitam sobre quais exercícios foram mais fáceis para vocês e quais foram mais difíceis. Pensem também sobre os possíveis motivos disso e escrevam suas conclusões na folha rosa.

3. Caso vocês ainda tenham tempo: discutam como se poderia estudar em casa com as páginas "Das kann ich schon" do Kursbuch e as páginas "Das hast Du schon gelernt" e "Grammatik" do Arbeitsbuch. Escrevam as conclusões na folha verde. 


\title{
Materiais disponíveis
}

\section{Das kann ich schon:}

\author{
Sätze und Wörter: \\ sich orientieren \\ Erlaubnis und Verbot \\ aussprechen \\ im Haus \\ in der Umgebung \\ Gegenstände im Haus \\ Sportarten

\section{GRAMMATIK}

rechts - links, oben - unten, hinten - vorn, drinnen - draußen im Keller / Erdgeschoss / ersten Stock

Man muss ... - Man darf nicht ... - Im Haus darf man nur ...

Eingang, Flur, Keller, Erdgeschoss, Schlafzimmer, Treppe, Küche See, Wald, Garten, Haus, Boot, Terrasse, Wiese, Straße, Baum 'Tisch, Stuhl, Bett, Schrank, Tür, Fenster

Rudern, Schlitten fahren/Rodeln, Tischtennis, Tauchen, Turnen, Leichtathletik: Laufen, Weitsprung, Hochsprung, Werfen

1. das unpersönliche Pronomen es

Es gibt einen See, ein Haus, eine Wiese und - Boote.

Es gibt + Akkusativ

2. Verb

a) Imperativ als Höflichkeitsform

Herr Meier, kommen Sie doch bitte mal!

Frau Scholz, helfen Sie mir bitte!

Herr und Frau Weber, sehen Sie mal!

b) Präteritum von haben

$\begin{array}{llll}\text { ich } & \text { hatte } & \text { wir } & \text { hatten } \\ \text { du } & \text { hattest } & \text { ihr } & \text { hattet } \\ \text { er/es/sie } & \text { hatte } & \text { sie/Sie } & \text { hatten }\end{array}$

3. Steigerung

$\begin{array}{llllll}\text { schnell } & \text { schneller } & \text { am schnellsten } & \text { gut } & \text { besser } & \text { am besten } \\ \text { groß } & \text { größer } & \text { am größten } & \text { viel } & \text { mehr } & \text { am meisten } \\ \text { alt } & \text { älter } & \text { am ältesten } & \text { gern } & \text { lieber } & \text { am liebsten }\end{array}$

hoch höher am höchsten 


\title{
Das kann ich schon:
}

\author{
Sätze und Wörter: \\ über das Befinden Wie geht es dir? - Mir geht es gut/schlecht. - \\ sprechen Geht's dir nicht gut? - Ich bin krank/erkältet. / Ich habe Fieber/Husten/ \\ Schnupfen/eine Grippe. / Mir ist heiß/kalt/schlecht. / Ich habe mich verletzt. \\ Was tut dir denn weh? / Tut/Tun dein/deine ... weh? - \\ Mir tut alles weh. / Mein/Meine ... tut/tun weh. - Gute Besserung! \\ Personen beschreiben Er/Sie ist groß/klein/schlank/... - Seine/lhre Haare sind blond/... \\ persönliche Angaben Mein familienname/Norname / meine Adresse / meine Telefonnummer ist ... \\ Körperteile Kopf, Mund, Zahn, Hals, Rücken, Oberkörper, Arm, Finger, Bauch, Po, \\ Bein, Knie, Fuß, Zeh, Haar, Ohr, Gesicht, Auge, Nase, Schulter, Brust, Hand
}

\section{GRAMMATIK}

1. Personalpronomen im Dativ

Wie geht es dir? _ $\quad$ Mir geht es schlecht. Mir tut alles weh.

Kann ich dir helfen? - Ja, helfen Sie mir bitte.

2. Possessivartikel im Nominativ und im Akkusativ

\begin{tabular}{|c|c|c|c|c|c|c|c|}
\hline \multirow{2}{*}{ Singular } & \multicolumn{3}{|c|}{ Nominativ } & \multicolumn{4}{|l|}{ Akkusativ } \\
\hline & Maskulinum & Neutrum & Femininum & & Maskulinum & Neutrum & Femininum \\
\hline \multirow[t]{3}{*}{ Das ist } & sein Mund & sein Mund & inr Mund & Ich mag & \multicolumn{3}{|c|}{ seinen Mund seinen Mund ihren Mund } \\
\hline & sein Knie & sein Knie & ihr Knie & & sein Knie & sein Knie & ihr Knie \\
\hline & seine Nase & seine Nase & ihre Nase & & seine Nase & seine Nase & ihre Nase \\
\hline Plural & Nominativ & & & Akkusativ & & & \\
\hline Das sind & seine Haare & seine Haare & ihre Haare & Ich mag & seine Haare & seine Haare & inre Haare \\
\hline
\end{tabular}

3. Fragepronomen im Nominativ und im Akkusativ

\begin{tabular}{|l|l|l|}
\hline & Nominativ & Akkusativ \\
\hline Maskulinum & Welcher Spieler ist das? & Welchen Spieler kennst du? \\
\hline Neutrum & Welches Trikot ist das? & Welches Trikot kennst du? \\
\hline Femininum & Welche Spielerin ist das? & Welche Spielerin kennst du? \\
\hline Plural & Welche Farben sind das? & Welche Farben kennst du? \\
\hline
\end{tabular}

4. Nebensatz mit weil

Warum bist du im Krankenhaus? Ich habe mich verletzt.

Weil ich mich verletzt habe

Ich bin im Krankenhaus, weil ich mich verletzt habe.

5. Vergleiche

Ein Ferrari ist genauso schnell wie ein Maserati.
Ein Auto ist schneller als ein Fahrrad. 


\section{Das hast du gelernt}

sich orientieren

rechts. oben

im

Erlaubnis und Verbote ausdrücken

Man muss

über das Befinden sprechen

Wie geht es dir? - Mir

Ich bin

Ich habe

Mir ist

Was tut

Mein

Gute

Personen beschreiben

Er/Sie ist

Seine/lhre Haare

persönliche Angaben machen

Mein Familienname

Räume im Haus

Eingang.

in der Umgebung

Gegenstände im Haus

See.

Sportarten

Körperteile Kopf.

Tisch.

24) vierundzwanzig 


\section{Grammatik}

1. Steigerung

a) Wie bildet man den Komparativ? Ergänze.

$\begin{array}{ll}\text { schnell } & \text { schneller } \\ \text { dick } & \\ \text { groß } & \text { größer } \\ \text { alt } & \\ \text { kurz } & \end{array}$

So bildet man den Komparativ:

Adjektiv +

Adjektiv mit Umlaut: $\mathrm{o} \rightarrow$ ,$a \rightarrow$

$\mathrm{u} \rightarrow$

b) Wie bildet man den Superlativ? Ergänze

\begin{tabular}{|c|c|c|}
\hline schnell & am schnellsten & $\mathrm{me}$ \\
\hline dick & & So bildet man den Superlativ: \\
\hline groß & & am + Adjektiv + \\
\hline alt & am ältesten & Adjektiv mit Umlaut: $\mathrm{o} \rightarrow \ldots$ \\
\hline kurz & & $\mathrm{u} \rightarrow$ \\
\hline heiß & & nach t, z, s/ß, sch: \\
\hline
\end{tabular}

\section{Nebensatz}

Wo ist das Verb? Kreuze an. ( $\mathbf{x}$

Ich trinke etwas, weil ich Durst habe.

Er spielt gut Fußball, weil er jeden Tag trainiert.

Hier steht das Verb:

weil

Im Nebensatz steht das Verb

immer am

\section{Possessivartikel. Ergänze.}

Hier ist Herr Meier.

Und das sind

sein Hund,

Pferd und

Katze.

Maskulinum: + Endung
Hier ist das Kind von Familie Meier. Und das sind

sein Hund,

Pferd und

Katze.

Neutrum:

+ Endung
Hier ist Frau Meier.

Und das sind

$\underline{\text { ihr }}$ Hund, Pferd und Katze.

\section{Femininum:} + Endung

Das ist Herr Meier. Und das ist sein e Katze.

$$
\text { Maskulinum A Femininum }
$$

Die Endung bezieht sich immer auf die Sache oder Person dem Possessivartikel. 
Transcrição das respostas.

\section{Respondentes: A2 e A5}

1. Olhar na folha de respostas

2. O exercício mais fácil foi o "1", pois tratava apenas de palavras mais fáceis e possuía exemplos. Os demais exercícios parecem mais confusos em seus enunciados.

3. Não fizeram

Respondentes: A7 e A14

1. Olhar na folha de respostas

2. O exercício mais fácil é o das hast du gelernt que são coisas mais simples e fáceis já os outros exercícios são mais difíceis de entender para poder fazer porque mexem com gramática e conjugações.

3. Dá para estudar, só que é um pouco mais difícil, porque vai estar sem orientações, vai ter que estar fazendo muitas pesquisas, principalmente de palavras.

\section{Respondentes: A10 e A13}

1. Olhar na folha de respostas

2. Os exercícios que tivemos mais facilidade de compreender foram os exercícios 1 e 2, pois ao olhar os "exemplos" nas lições, isso ajudou a entender o que estava sendo pedido. 
Os mais difíceis foram o 3 e o da página 24 pois demoramos um pouco para entender o que estava sendo pedido, e a gente teve dificuldade para interpretar o enunciado que não era claro.

3. Não fizeram.

\section{Respondentes: A11 e A12}

1. Olhar na folha de respostas

2. Grammatik 1 e 2 fáceis e legais.

Motivos - as explicações tornam mais fáceis para prosseguir com a resolução dos exercícios, e por serem matérias já estudadas, a compreensão é consequência da interpretação.

Difíceis: $1 b$ - por conta do Umlaut, ele acaba por confundir e nos limitar a compreender o vocabulário.

3. Não fizeram 
Anexo C - Atividade "Para refletir" aplicada no final do primeiro dia de coleta

\section{$\underline{\text { Para refletir }}$}

Nome:

1. Quais elementos do livro didático das estações anteriores você não conhecia?
( )Índice
()Wortliste
()Einstiegseite
( )Divisão das lições em módulos
( )Objetivos (Lernziele)
Outros

2. Qual desses elementos você gostaria de conhecer mais? Explique.

3. Como você percebe que aproveitou o conteúdo aplicado em aula?

() quando consigo fazer os exercícios

( ) quando consigo usar determinada estrutura ao falar

( ) quando escuto alguém falando e identifico uma palavra ou estrutura que aprendi

( ) quando tiro boas notas na prova

Outro

Procure explicar a sua opinião:

Transcrição das respostas

Respondente: A2

1. Wortliste/ objetivos (Lernziele) 
2. Eu gostaria de conhecer mais sobre a folha de vocabulário, pois apresenta inúmeras palavras essenciais para a formulação de frases, o que é indispensável para aprender o idioma e conseguir dialogar.

3. Quando consigo fazer os exercícios/ quando consigo usar determinada estrutura ao falar.

Procure explicar a sua opinião: Quando se aprende o conteúdo espera-se não esquecê-lo, logo, é fácil assimilá-lo a um exercício ou responder uma pergunta efetuada em um diálogo. No momento da fala é possível esquecer alguma palavra ou verbo, se realmente eu aprendi o que esqueci é possível mudar a frase sem perder o sentido. Conseguir utilizar o que foi ensinado em sala em uma conversação é o melhor para praticar e aprender mais.

\section{Respondente: A5}

1. Wortliste/ divisão das lições em módulos.

2. Gostaria de conhecer mais sobre Wortliste, pois não entendi esse elemento e também sobre Einstiegsseite [...]

3. Quando consigo fazer os exercícios/ quando consigo usar determinada estrutura ao falar/ quando escuto alguém falando e identifico uma palavra ou estrutura que aprendi.

Procure explicar a sua opinião: Porque quando eu consigo fazer os exercícios é que eu aprendi sobre aquele tema, e também quando eu escuto e identifico uma palavra é que gravei aquele determinado tema. Eu não acho que tirando uma boa nota na prova é suficiente, pois muitas vezes você "chuta" e acerta a questão e com os exercícios é diferente.

\section{Respondente: A7}

1. Wortliste/ Einstiegseite/ outros: das kann ich schon e Grammatik 
2. Das kann ich schon e Grammatik. A gramática e a conjugação para poder falar porque sofro muito com isso.

3. Quando consigo fazer os exercícios/ quando consigo usar determinada estrutura ao falar/ quando escuto alguém falando e identifico uma palavra ou estrutura que aprendi/ quando tiro boas notas na prova.

Procure explicar a sua opinião: Percebo quando estou entendendo e estou interagindo com o professor, com os colegas de classe e quando consigo desenvolver os exercícios. Quando realmente sei fazer, não com alguém dando respostas.

\section{Respondente: A10}

1. Wortliste/ Objetivos (Lernziele)/ Outros: A parte referente à gramática.

2. A parte referente à gramática, visto que os pequenos blocos de regras e exemplos são de grande ajuda. A parte dos objetivos, pois esta ajuda a focar no que estudar, ajuda em uma programação e auxilia no aprendizado de forma geral.

3. Quando consigo fazer os exercícios/ quando consigo usar determinada estrutura ao falar/ quando escuto alguém falando e identifico uma palavra ou estrutura que aprendi.

Procure explicar a sua opinião: Os recursos aprendidos em aula normalmente vêm a mente quando requisitados, e isto ocorre não somente em situações de prova ou em perguntas do professor, mas também quando me esforço para compreender uma fala ou texto, as técnicas de leitura e interpretação também se mostram efetivas. A única opção não marcada faz referência a provas, e o nervosismo da situação por vezes atrapalha no verdadeiro resultado.

\section{Respondente: A11}

1. Divisão das lições em módulos 
2. Gostaria de procurar saber mais, ou abordar melhor sobre o "das kann ich schon", consequentemente me transmite uma revisão muito bem detalhada e abrangente, o que em mim, amplia o conteúdo e acaba tirando diversas dúvidas. Os Tipps também são ótimas fontes para compreender e deveriam ser mais extensos, ou aparecer com mais frequência.

3. Quando consigo fazer os exercícios/ quando consigo usar determinada estrutura ao falar/ quando escuto alguém falando e identifico uma palavra ou estrutura que aprendi.

Procure explicar sua opinião: Toda e qualquer forma ao qual consigo identificar, como nas atividades de ouvir e/ou montar as estruturas da frase, isso me ajuda. Assim como ouvir músicas e traduzílas tornam a compreensão um fator de simplicidade e aumenta, em certa escala, o vocabulário.

\section{Respondente: A12}

1. Divisão das lições em módulos/ outros: Tipps!

2. Gostaria de conhecer um pouco mais o índice quando diz respeito a divisão em módulos, ou seja, qual é de fato o critério para a divisão em módulos? Mesmo sabendo que o livro usa um nível de fala da língua alemã gostaria de saber se há alguma relação quando falamos do módulo.

3. Quando consigo fazer os exercícios/ quando consigo usar determinada estrutura ao falar

Procure explicar a sua opinião: Para se aprender um idioma são necessários inúmeros métodos de aprendizagem, pois é algo no mínimo complexo. Desta forma, fazer o exercício demonstra na teoria se dominamos a gramática e suas regras de escrita; no entanto, tal ação é uma forma para fixarmos a estrutura frasal em nossa mente para em seguida falar a frase completa.

Contudo, as duas assinaladas são as opções fundamentais que desencadeiam as demais. 
Em uma analogia um novo idioma é um quebra-cabeças e os exercícios e a fala são os responsáveis por organizar as peças para que posteriormente se possa compreender a partir de testes como as provas ou conversas com outros falantes se de fato estamos aprendendo, seria a visualização da figura formada no quebra-cabeças.

\section{Respondente: A13}

1. Wortliste/ outros: Das kann ich schon

2. Das kann ich schon e Wortliste. Ambos me ajudariam a compreender melhor por causa do vocabulário e da gramática, que são coisas que acho importante.

3. Quando consigo fazer os exercícios/ quando consigo usar determinada estrutura ao falar/ quando escuto alguém falando e identifico uma palavra ou estrutura que aprendi/ outro: quando consigo ler um determinado texto e interpretar o que está escrito.

Procure explicar a sua opinião: Em grande parte consigo perceber o que aprendi quando consigo não só entender o que o professor diz durante as aulas, mas quando consigo falar, interpretar textos, resolver exercícios e escrever. Pois não só percebo o que aprendi mas também o que tenho dificuldade na qual eu posso solucioná-las, lendo, estudando, escrevendo e ouvindo, principalmente na parte da pronuncia que é algo que mais tenho dificuldade.

\section{Respondente: A14}

1. Objetivos (Lernziele)/ outros: a parte dos Tipps e da Strategie.

2. Os Tipps e as Strategie, que são partes que podem facilitar a aprendizagem do conteúdo proposto. $E$ também tenho uma certa curiosidade em saber como o Planet é organizado. 
3. Quando consigo fazer os exercícios/ quando consigo usar determinada estrutura ao falar/ quando escuto alguém falando e identifico uma palavra ou estrutura que aprendi/ quando tiro boas notas na prova.

Procure explicar a sua opinião: A minha opinião é que quando eu entendo palavras ou até o sentido geral de um texto ou de uma pessoa falando isso acaba trazendo uma sensação de "conquista da língua". E é ainda melhor quando você tira uma boa nota, pois é uma "adição de confiança" o que nos estimula a aprender com os meus erros e me esforçar ainda mais para conseguir uma nota alta novamente. 


\section{Anexo D - Estações e respostas da segunda etapa da coleta de dados}

\section{Estação 1: EINSTIEGSSEITEN und DAS KANN ICH SCHON}

\section{Materiais na mesa:}

Kursbuch, revistas, papéis coloridos e folhas de sulfite, cola, fita adesiva.

\section{Orientações.}

i. Observe as EINSTIEGSSEITEN e as seções DAS KANN ICH SCHON de cada um dos blocos temáticos do Kursbuch do livro Planet e responda (anote suas conclusões na folha branca sobre a mesa, use uma caneta para escrever suas observações):

a. Para que servem as Einstiegsseiten? Que elementos elas trazem? Você considera essa parte do livro importante e útil para a aula? (resposta no envelope verde)

b. Em que momentos aparecem as seções DAS KANN ICH SCHON? Para que você acredita que essa seção pode ser usada? Isso diz algo sobre a estrutura do livro? (resposta no envelope verde)

2. Use a sua criatividade e, junto com os colegas do grupo, monte uma versão de uma EINSTIEGSSEITE para os capítulos 17 a 20. Utilize a folha verde

3. Caso você ainda tenha tempo: Qual das duas páginas (EINSTIEGSSEITE ou DAS KANN ICH SCHON) você considera que é mais importante? - Discuta e escreva suas conclusões na folha azul.

\section{Materiais disponíveis}

\section{Resposta disponibilizada no envelope sobre a mesa (Primeira estação)}

1. A. AS EINSTIEGSSEITEN aparecem no início de cada um dos blocos temáticos do Kursbuch e servem para introduzir o(s) tema(s) abordados ao longo das quatro unidades que constituem cada bloco. Elas possuem imagens que têm relação com o tema, pequenos diálogos que visam gerar uma discussão inicial entre os alunos e, ainda, na parte inferior, uma lista com alguns aspectos linguísticos que serão trabalhados ao longo das unidades. 
B. A seção DAS KANN ICH SCHON aparece a cada duas unidades do livro. Desse modo, tendo em vista que o PLANET A2 tem inicio na unidade 17, a primeira seção DAS KANN ICH SCHON aparece ao final da unidade 18. Em geral, na parte superior dessa seção estão resumidos os conteúdos linguísticos abordados ao longo das duas unidades anteriores e, na parte inferior, aparecem tabelas com resumo dos conteúdos gramaticais. Essa seção pode ser usada como reflexão sobre os conteúdos aprendidos e, ainda, pode servir para que o aluno faça uma espécie de autocontrole sobre os conteúdos estudados.

\section{Resposta disponibilizada no envelope sobre a mesa (Segunda estação)}

1. A. Os exercícios são colocados em progressão, sempre do mais fácil para o mais difícil, além disso, existem símbolos ao lado de cada exercício que nos permite, por um lado, avaliar o seu grau de dificuldade e, por outro lado, localizar no Kursbuch o local no qual aquele tema foi tratado.

B. A página inicial das unidades e a seção DAS HAST DU GELERNT atuam como páginas de autocontrole para que o aluno possa avaliar o que foi aprendido por ele.

\section{Resposta disponibilizada no envelope sobre a mesa (Terceira estação)}

No dicionário é possível encontrar, além dos verbetes, uma seção com a organização do dicionário, outra com a transcrição fonética do alemão, as abreviaturas que serão usadas no dicionário e, no final, um apêndice com a conjugação de verbos fortes e regulares em alemão, uma lista com a conjugação dos verbos auxiliares e regulares em português e uma pequena lista de numerais.

\section{Transcrição das respostas}

\section{Respondentes: A2 e A14.}

1. A. As Einstiegsseiten servem para informar o tema das seguintes lições, trazem elementos do que vamos aprender nas lições. Esta parte do livro é importante para que o aluno saiba o que vai aprender. 
b. As seções aparecem no final de cada lição. É usado para consulta de algumas palavras e estrutura de frases. A seção aparece a cada duas seções de acordo com o tema.

2.

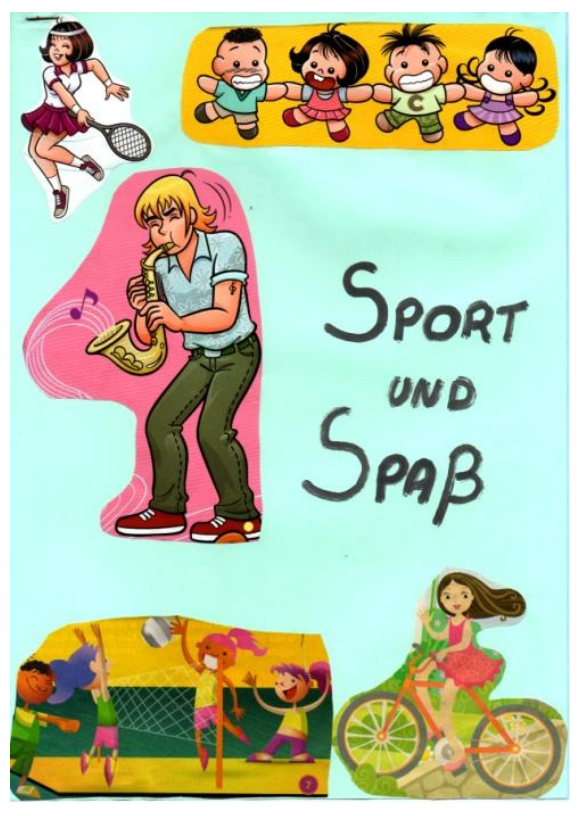

3. Não fizeram

Respondentes: A5, A6 e A12.

1.

a. Serve para que se tenha um resumo em tópicos do que se vai aprender no capítulo fazendo com que o aluno se sinta mais familiarizado com o tema mesmo sem conhecê-lo. Assim, o aprendizado é facilitado, pois o aluno se sente mais confortável com o que irá aprender.

c. Se encontram no final de cada capítulo, trazendo justamente um resumo, mas desta vez sobre o que já foi aprendido, o que facilita a fixação do idioma, mostrando a estrutura rotativa do livro que retoma as principais partes tratadas, que podem ser cobradas até mesmo em provas. 
2.

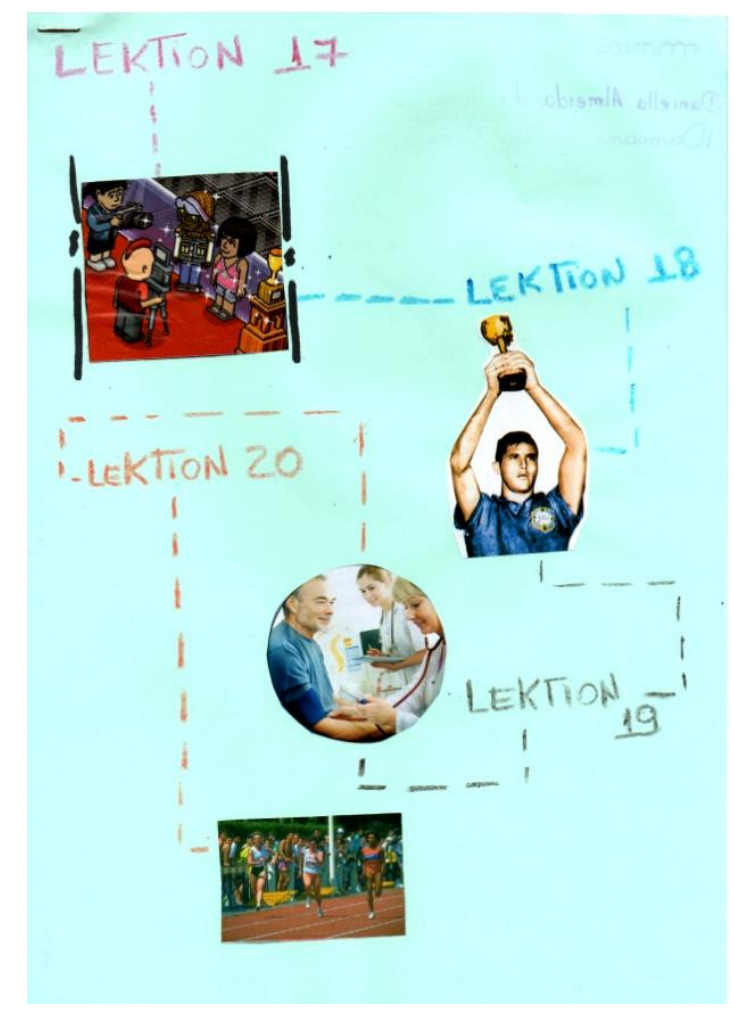

3. A página mais importante é a "Das kann ich schon", pois além de mostrar o que já foi aprendido ela mostra também como pode ser usado, demonstrando assim a autonomia que $o$ aluno adquiriu.

\section{Respondentes: A7 e A10}

1. A. Tem uma grande utilidade, mostra tudo que irá se passar todo o conteúdo dentro de um capítulo. Trazem imagens e falas referentes ao conteúdo. É importante sim! Tem grande utilidade.

b. Elas aparecem no final das seções sobre o assunto, e estas tem como utilidade demonstrar o que você domina sobre o assunto. Em respeito à estrutura do livro, a seção poderia ser melhor espalhada, com a finalidade de diminuir a quantidade de informação recebida pelo aluno. 
2.

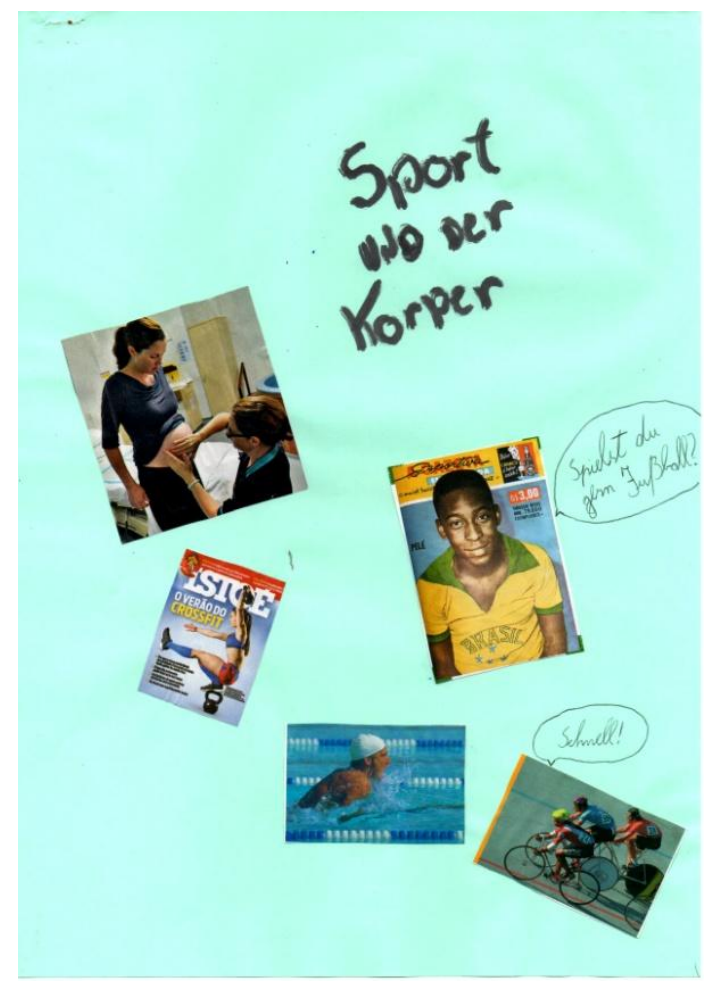

3. Não fizeram

Estação 2: Übungen im Arbeitsbuch

\section{Materiais na mesa}

Arbeitsbücher, réguas, cola, fita adesiva, canetinhas, papéis, revistas

\section{Orientações}

1. Observe a unidade 19 do Arbeitsbuch e reflita (anote suas conclusões na folha branca sobre a mesa, use uma caneta para escrever suas observações):

a. Existe alguma ordem na escolha em que os exercícios aparecem? É possível perceber algum tipo de ligação com o que foi visto no Kursbuch? (resposta no envelope verde) 
b. A página inicial das unidades do Arbeitsbuch e a seção intitulada $D A S$ HAST DU GELERNT são também exercícios ou têm outro tipo de função? (resposta no envelope verde)

2. Junto com seu grupo, montem na folha amarela dois exemplos de como seriam exercícios ideais para você. Para facilitar, escolha um dos temas já estudados em aula.

3. Caso você ainda tenha tempo: em que momentos o Arbeitsbuch poderia ser utilizado para estudar? Você considera importante utilizá-lo em aula? Escreva suas conclusões na folha azul

\section{Transcrição das respostas}

\section{Respondentes: A2 e A14}

1. A. aparentemente não, os exercícios só estão voltados ao mesmo tema. No Kursbuch se introduz o tema, a parte mais teórica, estimulando a parte prática, o Arbeitsbuch.

B. A página DAS HAST DU GELERNT tem por objetivo perguntar diretamente para o estudante se ele aprendeu ou não os conteúdos de cada parte do livro. Ambas as páginas são basicamente exercícios.

2. Feito na folha amarela

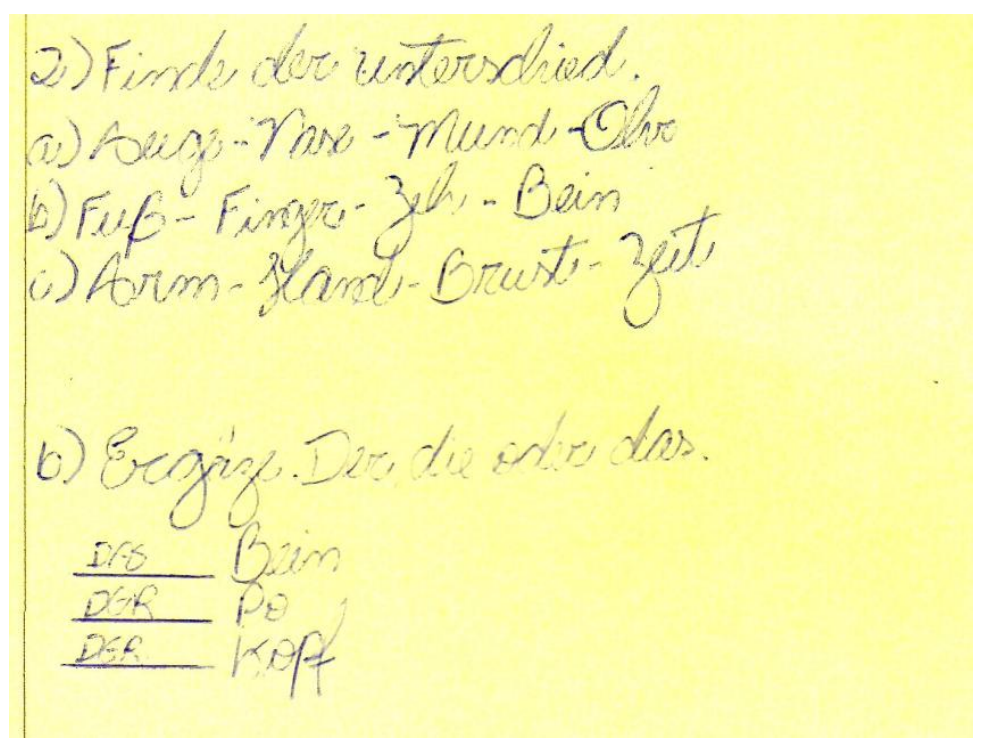


3. O Arbeitsbuch poderia ser utilizado em casa, para que o aluno pratique fora da escola o que foi passado em aula, dessa forma o conteúdo não seria esquecido.

\section{Respondentes: A5, A6 e A12}

1. A. segue a mesma sequencia do livro "Kursbuch" porém os exercícios aparecem de forma a se tornarem mais complexos conforme as unidades de ambos os livros vão se aprofundando no assunto se percebe também uma espécie de sequência no que diz respeito a gramática, vocabulário e interpretação.

B. É um tipo de exercício, porém, com uma função diagnóstica para que o professor tenha um controle ou saiba até mesmo como ajudar os alunos com dificuldade na atividade. Em suma, é uma revisão que propõe uma autoavaliação do aluno.

2.

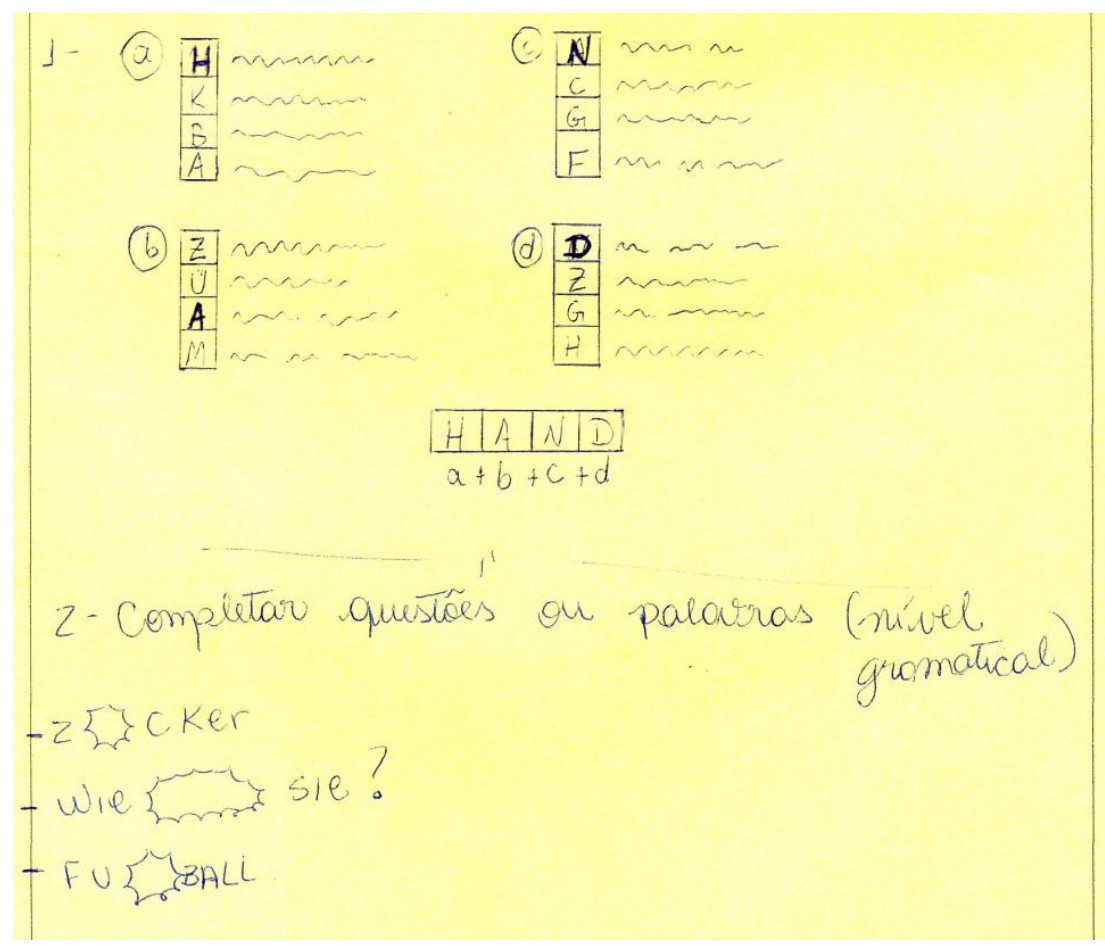

3. Em momentos que antecedem as avaliações, pois podem ser uma espécie de simulado, servindo assim como treino. Seu uso ganha importância quando o aluno está em casa já que na aula existe teoria e exercícios necessários e o "Arbeitsbuch" reforça e fixa o aprendizado pós aula. 
Respondentes: A7 e A10.

1. A. No geral, sim, porém os exercícios tratam de assuntos variados em curtos espaços de tempo. Sim, é evidente que os assuntos tratados no Arbeitsbuch estão presentes no Kursbuch.

B. Estas páginas tem como objetivo mostrar ao aluno o que ele possivelmente já aprendeu naquela seção do livro.

2.

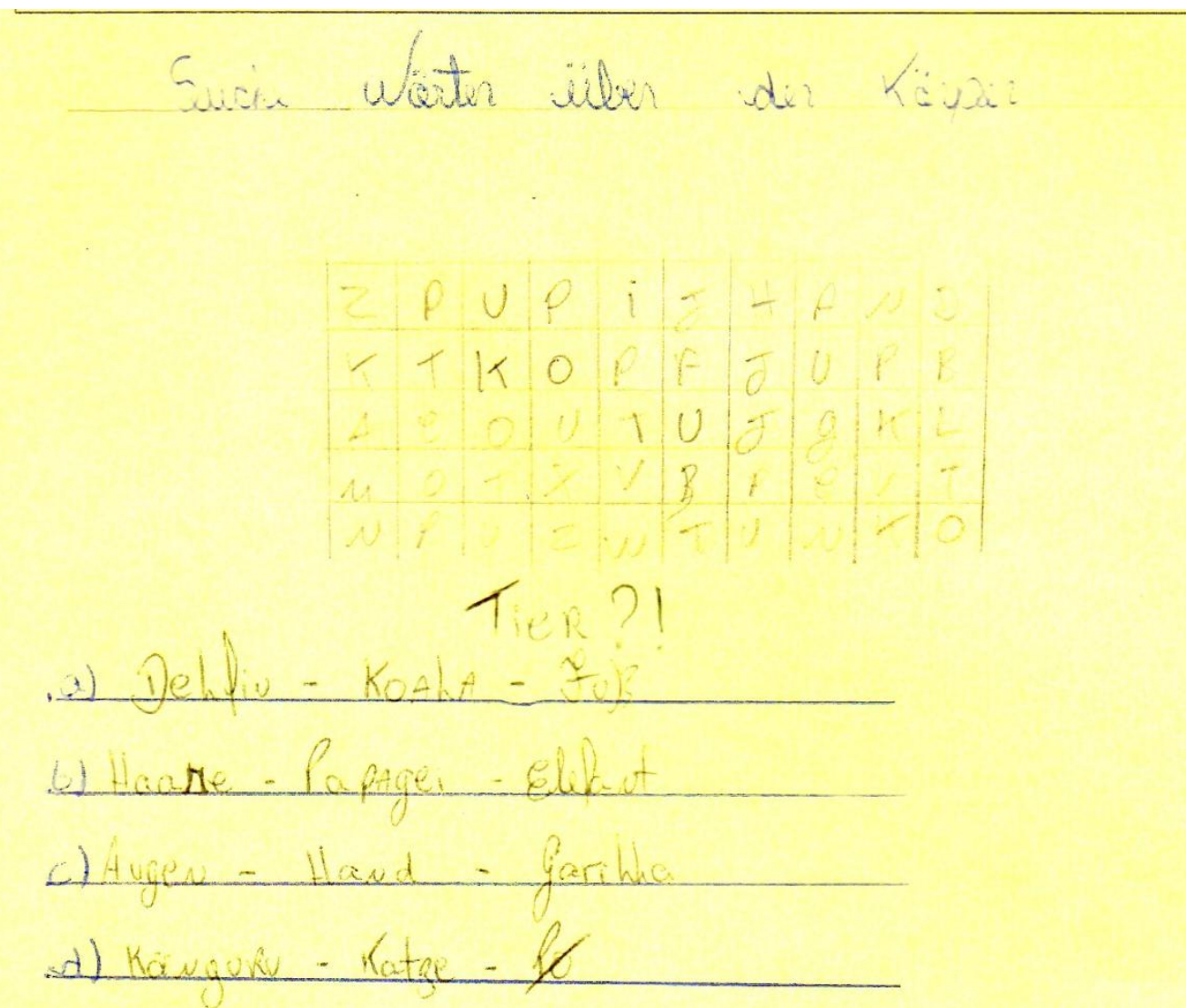

3. Em poucas situações, por ter um grande caráter mais revisionário. Em momentos de aula, tal conteúdo pode ser deixado, porém como lição de casa este é fantástico. 


\section{Estação 3: Wörterbücher}

\section{Materiais na mesa}

Dicionários/ cópias aumentadas das páginas

\section{Instruções}

1. Observe o dicionário desde as páginas iniciais e também as páginas finais. Você acha que o dicionário serve apenas para procurar palavras desconhecidas? O que mais pode ser encontrado? - anote suas conclusões na folha branca que está sobre a mesa. A resposta você encontra no envelope verde.

2. Observe a página do dicionário que está na mesa. Escolha algumas das palavras e indique a função dos símbolos e siglas que acompanham os verbetes. Anote suas conclusões na folha rosa.

3. Caso você ainda tenha tempo: Quando você acha que o dicionário é útil? Ele deve ser utilizado durante a aula? Em que momento? Escreva suas conclusões na folha azul.

\section{Transcrição das respostas}

\section{Respondentes: A2 e A14}

1. Não, além de encontrarmos o significado das palavras podemos encontrar informações sobre ortografias verbos, abreviaturas e números.

2. Ao lado do verbete encontra-se entre as chaves a transcrição fonética depois indica o gênero da palavra "FEM, MAS ou NT" e depois a terminação da palavra no plural.

3. O dicionário é útil, pode ser usado na construção de exercícios durante a aula para que o aluno não necessite tanto do professor para tirar suas duvidas. Assim deixando o professor livre para atender outros alunos. 
1. Não, pois além de fornecer as palavras com seus significados e traduções auxilia na compreensão fonética e gramatical da língua.

2. Normalmente todos os verbetes do dicionário apresentam sempre a descrição fonética, gênero (no caso dos substantivos), classe gramatical e plural. (Respondentes fizeram um esquema)

3. Ele é útil em todos os momentos de dúvidas e do aprendizado, sendo de grande importância dentro da sala de aula já que é o local onde há maior contato com o idioma, ficando assim mais contextualizado.

\section{Respondentes: A7 e A10}

1. Não só serve para achar palavras desconhecidas e sim a pronunciar que é chamada "fonética", gêneros das palavras e pronuncia fonética.

2. Entre parênteses, observa-se uma representação fonética da palavra em questão, e se bem instruído, o aluno pode tirar proveito disto com relação a dúvidas referentes a pronuncia. Por sua vez, as siglas representam diferentes sentidos, sendo aquelas acompanhadas por um "s" as que mostram o gênero da palavra em questão, ex: Szene Sf; pois Szene é um substantivo feminino. As demais representam se a palavra é um adjetivo, etc.

3. É útil por exemplo - dentro de uma frase tem alguma palavra chave que se eu souber a tradução consigo desvendar toda a frase. Tem que ser utilizado nas aulas. Deve ser utilizado em traduções de textos e frases. 


\section{Anexo E - Instruções, perguntas e textos da terceira etapa de coleta}

\section{Instruções para todos os grupos}

1. Junto com seus colegas, faça um pequeno resumo desse texto (em alemão)

2. Compare o que está escrito no texto com as suas experiências e escreva suas conclusões na folha que está sobre a mesa com a identificação do grupo (em alemão).

3. Respondam as questões que estão no slide sobre a mesa (em alemão).

4. Façam oralmente um resumo do texto que você leu para os demais colegas da sala (em alemão)

\section{Texto de base para a realização das atividades}

\section{Muttersprache}

Meine Muttersprache ist brasilianische Portugiesisch. Ich bin in São Paulo (SP), Brasilien geboren und seitdem wohne ich in der Stadt. Mein Vater kommt aus Bahia, trotzdem hat er keinen starken Akzent; meine Mutter kommt aus São Paulo. Deswegen spreche ich den ,,Paulistano“ Dialekt.

\section{Fremdsprache}

Es ist schwer zu wissen, welche meine erste Fremdsprache war, weil ich in der Schule Englisch und Spanisch Unterricht hatte. Die Unterrichtstunde waren nicht so gut, aber ich habe etwas gelernt. Ausserdem hörten meine Eltern gern internationale Musik, insbesondere Musik auf Englisch. Deshalb hatte ich als Kind Kontakt mit Englisch auch ausser die Schule. Als ich 9, 10 Jahre alt war, schaute ich die mexicanische Seifenoper "Rebelde" an und hörte die Musik der Band „RBD“ auf Spanisch, und begann ich mich auch für amerikanische und englische Musik zu interessieren - wegen Disney Channel und Pop Musik. Deswegen kann ich nicht klar sagen, ob Englisch oder Spanisch meine erste Fremdsprache war.

\section{Wie Ich am besten Sprachen lerne?}

Ich habe Motor-Speicher, deswegen lerne ich sehr beim schreiben. Das war mir sehr wichtig, als ich den Kurs im CEL gemacht habe, weil dabei konnte man kein Buch nach Hause mitnehmen. Darum musste ich viel kopieren und schreiben. Aber ich denke, dass es mir nur im A1 und A2 Niveau klappt, weil zurzeit ist es nicht so. Ich denke, dass heutzutage ich die Sprache nicht nur durch die Sprache lerne. Was ich 
meine ist, dass ich lerne am besten, wenn die Sprache ein Hilfsmittel um etwas anders zu verstehen oder lernen ist, z.B. beim Aquisição/Aprendizagem de Alemão como Língua Estrangeiras Unterricht. Dabei MUSS ich Texte auf Deutsch lesen und viel auf Deustch schreiben und hören und sprechen. Dabei verweigern ich mich auf Portugiesisch zu sprechen oder schreiben und damit lerne ich sehr.

Obwohl ich die Deutsche Sprache sehr mag, habe ich nicht viele Selbstmotivation um allein zu lernen. Deswegen besuche ich immer noch Kurse und Seminaren an der Uni, in denen ich viel Kontakt mit dem Deutschen habe und die Sprache üben muss. Ich versuche auch deutsche Musik zu hören und Nachrichten auf Deutsch zu schauen und lesen - insbesondere Nachrichten, deren Themen ich gut kenne. Ausserdem skype ich oft mit meinen Deutschen Freunden, um meine Fähigkeiten beim Sprechen zu verbessern.

\section{Meine Pläne für die Zukunft}

Ich will C2 Niveau in Deutsch erreichen und mein Master in Deutschland machen. Fremdsprachen zu lernen macht mir viel Spass, deswegen möchte ich auch fliessend in Spanisch und Englisch zu werden, weil ich ein Master über die Rezeption der lateinamerika Literatur in Deutschland machen will, um die brasilianische Literatur auszubreiten. Dann würde ich gern eine andere Fremdsprache lernen vielleicht Hebräisch oder Arabisch. Hebräisch, damit ich die Bibel besser lesen kann und Arabisch, weil ich einer jordanischen Flüchtlingen Familie Portugiesisch unterrichte und die Arbeit mit Flüchtlinge - insbesondere Araber - mich sehr interessiert und mir sehr gefällt. Auch wenn ich in Deutschland wohne, würde ich noch gern mit Flüchtlinge arbeiten und innen vielleicht Deutsch beibringen.

\section{Perguntas para cada Grupo de acordo com o tema}

\section{Teil 1: Meine erste(n) Sprache(n)}

Mit welchen Sprachen bin ich aufgewachsen?

Wie hatte ich kontakt zu diesen Sprachen? Wer hat mir mit diese Sprachen gesprochen?

In welchen Sprachregionen habe ich gelebt?

Teil 2: Meine Fremdsprachen

Welche Sprachen habe ich in der Schule gelernt?

Wie war der Unterricht? (Dauer, Intensität, Materialien, Aktivitäten, usw.)

Habe ich außerhalb der Schule weitere Sprachen gelernt? Wo und wie? 
Wann und wie benutze ich meine Fremdsprachen heute? (z.B. bei der Arbeit, im Studium, im Bekanntenkreis, auf Reisen)

\section{Wie ich am besten Sprachen lerne:}

Welche Aktivitäten mache ich gerne, um z.B. Wortschatz, Grammatik, Aussprache, Hör- uns Lesenverstehen zu üben?

Welche Texte schreibe oder lese ich manchmal in meinen Fremdsprachen?

Was mache ich, um meine Fremdsprachen auch mündlich zu üben?

\section{Meine Pläne für die Zukunft}

Welche Sprachkenntnisse möchte ich ausbauen und warum?

Welche neue Sprache möchte ich vielleicht lernen und warum?

Wofür brauche ich die Sprachen, die ich (weiter) lernen möchte?

In welchen Kontexten möchte ich diese Sprachen benutzen?

\section{Respostas dos grupos}

\section{Grupo 1}

1. Muttersprache.

Der Junger hat weil er und deine Eltern sprechen „Paulistano“ dialekt. Deine Mutter spricht gut Paulistano Dialekt und er wohnen in São Paulo. Aber dein Vater kommt aus Bahia, und er spricht Bahiano Dialekt nicht gut. Er hat keinen starken Akzent und er hat nicht Bahiano Dialekt von der Junger gesagt.

Jetzt die Familie wohnen in São Paulo und sie sprechen nur „Paulistano“ Dialekt.

\section{Fremdsprache}

Jetzt, in diese text der Junger spricht über Fremdsprache. Er ist verrükt weil er englisch un spanisch etwas lernt, und er weiss nicht deine erste Fremdsprache.

In der Schule, er hat zwei Unterricht hatte: englisch und spanisch aber er spricht nicht so gut. Er hat mit Musik und Seifenoper gelernt.

Englisch und spanisch gefällt ihm gut aber er kann nicht klar sagen 
2. Meine Familie und die Familie auf meine Kollege haben in Brasilien geboren und jetzt wir wohnen in São Paulo.

Die zwei Familien kommen aus Nord aber sie sprechen gut „Paulistano“ Dialekt weil sie die nord Dialekt vergessen.

Wir haben in São paulo geboren dann haben wir nicht nord Dialekt gelernt.

Aber wir haben internationale sprache gelernt. Die erste Fremdsprache war englisch weil wir in der Schule Unterricht. Englisch gefällen uns gut, aber haben wir Deutsch auch gelernt. Wir sprechen nicht klar diese zwei Framdsprache.

Wir sehen Film und hören Musik in Deustch und Englisch. Fremdsprache ist interessant als Brasilien Dialekt.

3.

Teil 1:

- wir sind mit Portugiesisch aufgewachsen.

- Wir haben kontakt zu diesen Sprachen in unsere Familie, mit unsere Mutter. Oma und unser Vater.

Teil 2:

- In der Schule wir haben Portugiesisch und etwas englisch gelernt.

- Der unterricht war mit materialen auf die Stadt und nicht Intensität. Wir lernen etwas gelernt.

- Wir haben kürz auf Deustch. Es ist nicht mit normal Schule aber wir haben die Stunde in einen Schule.

- Heute haben wir Portugiesisch gesagt aber jetzt in der Nacht bei der Schule wir benutze deutsch mit Aktivität.

\section{Grupo 2}

1. In die Texte sprechen von ein schuler bei CEL, er lernt und schrebt Deutsch in Kurs er sprecht immer deutsch im Kurs. Aber heutzutage er lernt nicht Deustch und er hat Hilfsmittel zu lernt deutsche. Damit lernt er sehr und Deutsch spracht sehr magt. Und er hat viel kontakt mit dem sprachen. Das ist sehr gut, weil er hat ein Freunden Deutsch, dann viel lernt.

2. Ich mag deutsche und höre, schreibe, sprache Deustch in den Kurs. Ich habe kurs im Cel auch gemacht, dann ich lerne deutsch mag. Aber ich hat Hilfsmittel nicht in mein Hause und mein Leben. Das ist sehr träurig. Aber das was.

3.

- Ich gerne pop musik hören und sehr sprache deutsch, dann ich üben Aussprache und hören Aktivitäten. 
- Ein Texte im Deustch einmal. Aber ich schreibe ein bisschen Deustch, dann ich finde dass gut gewessen.

- Ich mache spanisch im CEL, dann üben ich spreche spanisch.

\section{Grupo 3}

1. Die Person auf den Text würden die C2 Niveau in Deutsch geschaft. Sie möchten in Spanisch undnglisch fliessend bekommen, weil sie muss ein Master über die ezeption der lateinamerika Literatur in Deutschland machen. Die Person möchten Hebräisch oder Arabisch lernen. Hebräisch wiel sie Bibel besser lesen, und arabisch weil sie hat einer jordanischen Flüchtlingen Familie wenn sie in Deutschland wohne, würden sie mit Flüchtlinge arbeiten.

2. A2: ich will Ernährungswissenschaften und A2 Niveau in Deutsch erreichen.

A10: ich will B1 und B2 in Deutsch erreichen und Chemie am die Universität 3. gestudiert.

- Ich möchte englisch und deutsch ausbauen, weil finde ich wichtig.

- Ich möchte russisch und französisch lernen, weil finde ich sehr interessant.

- Für arbeiten und der kenntnis ausbauen.

- In Reisen. 


\section{Anexo F - Sprachbiografien}

\section{Respondente A1}

Eu sou do Brasil, mas tive grande influência de fora do país, por parentes não muito distantes. Com isso tive uma grande ajuda de alguns parentes para aprender de certa forma o português falado formal. Isto aparenta ser estranho porém sempre tive claro comigo que para aprender outra língua deveria primeiro dominar a minha língua materna. Desta forma sempre busquei formas de me atualizar para que tenha um bom português. Assim desde pequeno já gostaria de me empenhar e me aventurar em outra lingua e como já havia falado em minha familia tive contato com algumas línguas como italiano, alemão e espanhol.

Sendo que a primeira língua a ser estudada por mim foi o „Deutsch“ e apesar de ultimamente não estar tão atuante na língua, tenho intenção de me especializar na lingua por meio de cursos e talvez graduação. Vejo que sou bem encaminhado, mas sinto que falta tempo para me aprofundar mas assim parece ser mais prazeroso, pois sinto que necessita de um esforço e dedicação para aprender a língua. No futuro me vejo como um professor dominante da língua e creio que não posso deixar o estudo para traz, pois devo terminar o que comecei, assim como uma flecha lançada, não tem volta.

\section{Respondente A2}

Muttersptache: minha língua materna é o português, porém, tenh parentes que vieram da lugoslávia (ou Hungria, não tenho certeza), infelizmente não os conheci. Minha família fala português e arriscam um pouco de inglês. A única pessoa que conhece a língua dos meus parentes é a minha avó, ela conhece somente algumas frases.

Fremdsprache: meu primeiro contato com uma língua estrangeira foi na escola, onde o inglês é matéria básica. Em 2014 iniciei um curso de espanhol no CEL, porém, não terminei pois iniciei outro curso. No CEL também tive meu primeiro contato com o alemão. 
Wie lerne ich: eu gosto de ouvir músicas para aprender primeiramente a pronúncia das palavras. Também gosto de pesquisar o significado das palavras nas letras das músicas.

Pläne für die Zukunft: eu pretendo fazer faculdade de nutrição, mas também quero me aprofundar nos idiomas (principalmente inglês e alemão). Gostaria de viajar para a Alemanha, onde poderei praticar o alemão.

\section{Respondente A5}

\section{Muttersprache}

Minha língua materna é o português, moro em São Paulo, meu pai veio do Pará, norte do Brasil e ele não fala com sotaque de lá pois mora aqui há muito tempo. Minha mãe nasceu em São Paulo e não adquiriu o sotaque de algum lugar como o Pará.

\section{Fremdsprache}

Assim como o português, queria aprender outras linguas. Comecei com inglês na escola, depois comecei a estudar alemão, no CEL de Caieiras. Queria me aprofundar em inglês então comecei a cursar no CEL essa língua. Escuto músicas em alemão e inglês, assisto vídeos etc.

Para me aprofundar nessas línguas além de ouvir músicas e assistir vídeos eu faço atividades, venho para o curso e algumas vezes eu converso com meus amigos em alemão ou inglês.

\section{Pläne für die Zukunft}

Eu espero poder falar fluente essas duas linguas, aprender novas línguas estrangeiras, viajar e saber conversar, pedir e comprar usando a língua que estou aprendendo. Gostaria de usar essas línguas futuramente para minha profissão pois quero ser advogada e posso ter contato com pessoas estrangeiras ou até mesmo ir para algum país representar um caso ou cliente. 


\section{Respondente A7}

Eu sou brasileiro, meus pais tambem são brasileiros e boa parte da minha família é brasileira. Tenho dois tios por parte de mãe que moram nos EUA. A tia da minha namorada também mora nos EUA. Na minha infância não demorei muito para poder falar as primeiras palavras. Meu primeiro contato com o inglês por ouvir músicas e assistir filmes e depois conhecer amigos que falam inglês fluente. Depois conheci a língua alemã atravéz de saber que a empresa que meu pai trabalha é alemã e me apaixonei. Tenho sonhos de morar e conhecer primeiro e assim comecei a pesquisar e achei o CEL Caieiras que dava aulas de alemão, e comecei a fazer e sempre estudando quando dava. Pensei muito em desistir, mas aos poucos que vai aprendendo. Tenho muita dificuldade por conta do aprendizadi da escola que tive, não tenho um cronograma de estudos, mas sempre que tenho tempo estudo um pouco e para o futuro quero conhecer a Alemanha e conseguir falar fluente.

\section{Respondente A10}

Minha língua materna é o português, assim como é para a minha família, e também para o meu país, o Brasil. Mesmo que todos falem português, os dialetos diferem o de meu pai e de seus pais que são paranaenses, já os da parte da minha mãe são do nordeste e o meu era como uma mistura de paranaense, nordestino e paulista. Quanto à línguas estrangeiras, apenas eu e um tio meu dominados alguma, ele inglês, eu alemão e inglês, além de querer aprender árabe e russo, por gostar de tais línguas. Para treinar essas línguas, normalemnte utilizo aplicativos de aprendizado e tento interagir com falantes da língua ou com aqueles que querem aprender ou, se possível, através de jogos. Para o futuro, desejo utilizar a língua em viagens e interações sociais com outros povos e culturas.

\section{Respondente A12}

Muttersprache

Minha língua é o português, já que nasci no Brasil assim como os meus pais. Grande parte da minha familia veio da região nordeste, porém, como vivem há muito 
tempo na cidade de São Paulo, mal falam com sotaque do estado em que nasceram. Como nasci aqui em São Paulo, meu único sotaque é o paulista.

\section{Fremdsprache}

Assim como muitos brasileiros, meu primeiro contato com uma língua estrangeira se deu com o inglês ja que é algo muito presente em nosso país. De início meu contato se resumia a ouvir músicas, pois desde pequena comeceiu a gostar muito de música americana, especialmente da cantora Katy Parry. Algum tempo depois iniciei meu curso de inglês, o que me ajudou a comprender melhor a gramática. Com 14 anos, tive a oportunidade de conhecer o CEL e iniciei o curso de espanhol. Seis meses depois descobri que era permitido fazer dois cursos simultaneamente, então como já estava curiosa para saber como era o curso de alemão, me matriculei. Sem dúvidas o alemão foi o idioma que mais gostei e acabei parando o curso de espanhol antes do tempo. Infelizmente não falo tão bem nenhum deles, talvez falte um pouco de treino principalmente na fala.

\section{Wie lerne ich}

Costumo realizar as atividades pedidas em aula, e no caso do alemão busco também procurar alguns videos e prencipamente desenhos infantis, confesso que alguns vocabulários me assustam.

\section{Pläne für die Zukunft}

Como desejo fazer medicina e tenho imensa admiração pelo idioma alemão tento conciliar ambos. Pretendo, durante a faculdade realizar algumas materias do curso de letras - alemão para que não pare de estudar, pois o contato com o alemão é dificil. Sendo assim, pretendo principalmente falar alemão bem, para que possa realizar talvez intercâmbio na Alemanha e até mesmo alguma especialização na área médica. 


\section{Anexo G - Questionário 1}

Etapa 1 - 10/05/2017

\section{Questionário de pesquisa}

Estudo sobre o livro didático no processo de aprendizagem de alemão no CEL.

Gostaríamos de pedir-lhe para responder as seguintes questões que dizem respeito aos usos do livro didático no processo de aprendizagem de alemão no CEL. $A$ pesquisa é conduzida pelo programa de pós-graduação em Língua e Literatura Alemã do Departamento de Letras Modernas da Universidade de São Paulo e tem como objetivo investigar a importância atribuída a esse dispositivo pelos alunos. Vale ressaltar que não existem respostas certas ou erradas para as questões a seguir. Estamos interessados na sua opinião e pedimos para que você responda da forma mais sincera possível, pois isso garantirá o sucesso da pesquisa. Agradecemos pela sua ajuda.

\section{Parte 1: Dados pessoais e histórico de aprendizagem de LE}

1) Nome:

2) Idade:

3) Ainda frequenta o ensino fundamental ou médio?

( ) sim, o ensino fundamental

( ) sim, o ensino médio

( ) não

4) Em uma escala de 1 a 4, onde 1 representa "baixo" e 4 representa "alto", qual é, na sua opinião, o seu desempenho com a língua alemã nas aulas do CEL?

Baixo ( 1 ) ( 2 ) ( 3 ) ( 4 ) alto 


\section{Parte 2: LD na sala de aula}

5) Na sua sala, há exemplares em quantidade suficiente do livro didático para todos os alunos usarem durante as aulas?
( ) sim
( ) não

6) Você acredita que a quantidade de livros didáticos disponíveis pode ajudar ou prejudicar a aula de alguma forma? Procure explicar a sua opinião.

7) Em uma escala de 1 a 6, qual a importância que você atribui ao livro didático para a aula de alemão? 1 representa "pouca importância" e 6 representa "muita importância"

Pouca importância ( 1 ) ( 2 ) ( 3 ) ( 4 ) ( 5 ) ( 6 ) Muita importância

8) Em relação ao tempo, qual a porcentagem da aula que costuma ser preenchida com o uso do livro didático?
( ) menos de $20 \%$
( ) entre 20 e $40 \%$
( ) entre 40 e $60 \%$
( ) entre 60 e $80 \%$
( ) mais de $80 \%$

9) Em uma escala de 1 a 6, onde 1 representa "pouco satisfeito" e 6 representa "muito satisfeito", qual é o seu grau de satisfação com o livro didático utilizado nas aulas de alemão?

Pouco satisfeito ( 1 ) ( 2 ) ( 3 ) ( 4 ) ( 5 ) ( 6 ) muito satisfeito 
10) Procure explicar a sua opinião sobre a questão 9.

Nas questões 11 e 12, complete as afirmações (sublinhe o conector que será utilizado na sua resposta):

11)Gosto do livro didático quando/ pois:

12) Não gosto do livro didático quando/ pois:

13) Em uma escala de 1 a 6 , onde 1 representa "pouco" e 6 representa "muito", qual é a importância que você atribui ao livro didático para você durante a aula de alemão?

$$
\text { Pouco ( } 1 \text { ) ( } 2 \text { ) ( } 3 \text { ) ( } 4 \text { ) ( } 5 \text { ) ( } 6 \text { ) Muito }
$$

14) Você acha que a aula de alemão fica melhor quando todos os alunos possuem um exemplar? Em que sentido? Justifique brevemente

15) Você já pensou sobre como seria um livro didático ideal? Procure explicar sua opinião. 


\section{Anexo H - Questionário 2}

Etapa $2-07 / 06 / 2017$

\section{Questionário de pesquisa}

Estudo sobre o livro didático no processo de aprendizagem de alemão no CEL.

Gostaríamos de pedir-lhe para responder as seguintes questões que dizem respeito aos usos do livro didático no processo de aprendizagem de alemão no CEL. $A$ pesquisa é conduzida pelo programa de pós-graduação em Língua e Literatura Alemã do Departamento de Letras Modernas da Universidade de São Paulo e tem como objetivo investigar a importância atribuída a esse dispositivo pelos alunos. Vale ressaltar que não existem respostas certas ou erradas para as questões a seguir. Estamos interessados na sua opinião e pedimos para que você responda da forma mais sincera possível, pois isso garantirá o sucesso da pesquisa. Agradecemos pela sua ajuda.

\section{Parte 1: Dados pessoais e histórico de aprendizagem de LE}

1) Nome:

2) Você já estudou alemão em outra instituição, além do CEL? Em caso afirmativo, indique a instituição e a duração do curso.

( ) $\operatorname{sim}$

( ) não

3) Além do alemão, em quais outras línguas você possui algum tipo de conhecimento? (você pode assinalar mais de uma alternativa)
( ) inglês
( ) espanhol
( ) francês
( ) italiano
( ) outros: 
4) Você já frequentou aulas de outro idioma em alguma outra instituição? (Em caso afirmativo, indique a instituição, a duração do curso e o idioma estudado)
( ) $\operatorname{sim}$
( ) não

5) Como você ficou sabendo do curso de alemão no CEL?

6) Por que você decidiu se inscrever para o curso?

\section{Parte 2: Autonomia e estudo em casa}

7) Você possuí uma cópia do livro didático (Kursbuch e Arbeitsbuch) em casa? (você pode assinalar mais de uma opção)
( ) sim, o Kursbuch original
( ) sim, o Kursbuch em pdf
( ) sim, o Kursbuch impresso
( ) sim, o Arbeitsbuch original
( ) sim, o Arbeitsbuch em pdf
( ) sim, o Arbeitsbuch original
( ) sim, o Arbeitsbuch impresso
( ) não, não possuo os livros

8) Em uma escala de 1 a 6 em que 1 representa "pouca importância" e 6 representa "muita importância", qual é, na sua opinião a importância de se ter uma cópia do livro didático em casa. 
Pouca importância (1) (2) (3) (4) (5) (6) Muita importância

9) Procure explicar a sua opinião sobre a questão 8:

10) Você costuma estudar alemão em sua casa com frequência?
( ) $\operatorname{sim}$
( ) não

11) Quantas horas, em média, você estuda alemão em casa por semana?

( ) menos de 1 hora

( ) entre 2 e 4 horas

( ) entre 4 e 6 horas

( ) entre 6 e 8 horas

( ) mais de 8 horas

12) Como você estuda em casa? Procure dar exemplos concretos sobre a sua rotina de estudos em relação ao alemão.

13) Quais dos materiais abaixo você utiliza para estudar em casa?
( ) o livro didático
( ) dicionários (impressos ou online)
( ) listas de palavras
( ) aplicativos de celular
( ) outros livros didáticos diferentes do usado em aula* (assinalando essa alternativa, responda a questão 14)

( ) outros: 
14) Quais são os outros livros didático que você costuma utilizar para estudar alemão em casa?

15)Enumere o grau de importância que você atribui aos materiais de estudo usados em casa utilizando os materiais listados na pergunta anterior e outros que você considerar importantes. O número 1 representa o material mais importante e o número 4 , o menos importante.

(1)

(2)

(3)

(4)

16) Como você avalia o seu grau de autonomia para estudar alemão em casa? 1 representa "pouco autônomo" e 6 representa "muito autônomo".

Pouco autônomo (1) (2) (3) (4) (5) (6) muito autônomo

17) Na sua opinião, o que significa ser autônomo no estudo de uma língua estrangeira?

18) Complete as frases (grife o conector utilizado):

Estudar em casa é importante pois/ porque:

Estudar em casa seria mais fácil se/ quando: 